UNIVERSIDADE DE SÃO PAULO

FACULDADE DE FILOSOFIA, LETRAS E CIÊNCIAS HUMANAS

DEPARTAMENTO DE SOCIOLOGIA

PROGRAMA DE PÓS-GRADUAÇÃO EM SOCIOLOGIA

\title{
Afinal, espiritismo é religião? \\ A doutrina espírita na formação da diversidade religiosa brasileira
}

\section{CÉLIA DA GRAÇA ARRIBAS}

Dissertação apresentada ao Programa de Pós-Graduação do Departamento de Sociologia da Faculdade de Filosofia, Letras e Ciências Humanas da Universidade de São Paulo, para a obtenção do título de Mestre em Sociologia.

Orientador: Prof. Dr. Antônio Flávio de Oliveira Pierucci 
À minha mãe

in memorian 


\title{
Resumo
}

Pretendeu-se analisar o processo de formação da heterogeneidade formal do campo religioso brasileiro tomando por objeto empírico o desenvolvimento de parte da produção intelectual religiosa durante as últimas décadas do século XIX. Examinando sociologicamente a emergência do espiritismo religioso, almejou-se entender e explicitar em sua lógica própria o processo de constituição de um mercado competitivo de bens de salvação caracterizado pela perda do monopólio religioso da igreja católica e pela ascensão da legitimidade institucional das outras religiões. Relacionando a idéia weberiana de racionalização das esferas de valor no caso a religiosa - e as noções de trabalho e de divisão do trabalho religioso de Pierre Bourdieu, propôs-se uma análise das lutas dos grupos de agentes cujos interesses materiais e simbólicos tornam o campo religioso um terreno de operação para as lutas entre diferentes empresas de salvação.

Palavras-chaves: Sociologia da Religião; Intelectuais da Religião; Espiritismo; Catolicismo.

\begin{abstract}
This work aims to analyze the formation of the pluralism in Brazilian religious field. Its empirical object is the development process of part of the intellectual production on Religion during the last decades of the 19th century. A sociological examination of the emergency of the religious Spiritism was made in order to explain, through its own logic, the constitution process of a competitive goods salvation market. This research shows that this market is characterized by the loss of the religious monopoly from the Catholic Church and by the rising of the institutional legitimacy from other religions. By relating the Weberian idea of rationalization of the value spheres - in this case, the religious one - to the concepts of religious work and division of the religious work from Pierre Bourdieu, this research proposes an analysis of the struggles among the groups of agents whose material and symbolic interests have made the religious field become a field of operation for the struggles between different salvation companies
\end{abstract}

Keys-words: Sociology of Religion; Intellectuals of Religion, Spiritism; Catholicism.

\section{Résumé}

On a eu l'intention d'analyser le processus de la formation de la diversité formelle du champ religieux brésilien, prenant pour objet empirique le développement d'une partie de la production intellectuelle religieuse pendant les derniers années du XIXème siècle. En examinant sociologiquement l'émergence du spiritisme religieux, on a eu pour objectif comprendre et expliciter dans sa logique propre le processus de la constitution d'un marché compétitif de biens du salut, caractérisé par la perte du monopole religieux de l'Église Catholique et de l'ascension de la légitimité institutionnelle des autres religions, em particulier le spiritisme. Reliant l'idée wébérienne de la rationalisation des sphères de valeur - dans ce cas la sphères religieuse - et les notions du travail religieux et de la division du travail religieux de Pierre Bourdieu, on a proposé une analyse de la formation du champ en question. Sa dynamique interne serait ainsi liée aux combats des groupes d'agents. Les intérêts matériels et symboliques de ces groupes rendent le champ religieux un terrain d'opération pour les combats entre différentes enterprises de salut.

Mots-clés: Sociologie da la Religion ; Intellectuels de la Religion ; Spiritisme ; Catolicisme. 


\section{Índice}

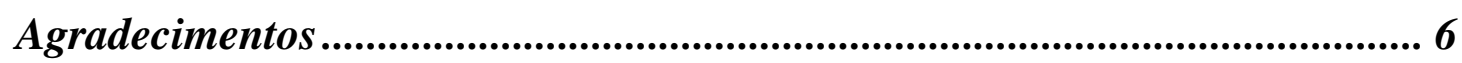

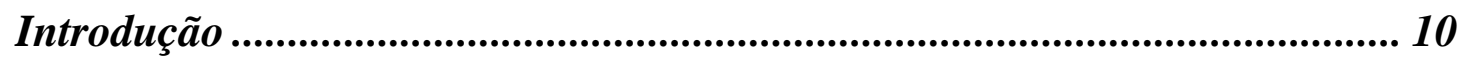

Capítulo I - A “Reforma” espírita ............................................................... 19

Espiritismo, o termo de distinção ................................................................... 19

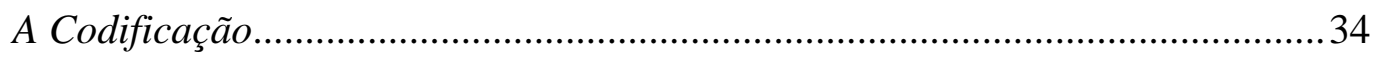

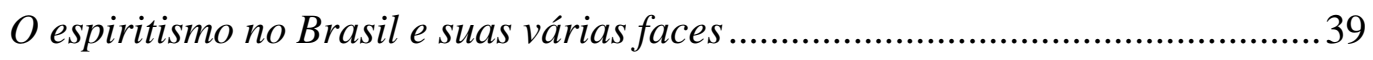

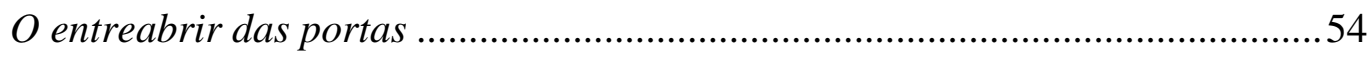

Afinal, espiritismo é religião?..................................................................... 71

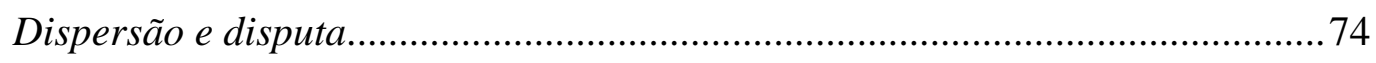

Capítulo II - "Pelo fruto se conhece a árvore" ou o critério da escolha dos

intelectuais............................................................................................................................ 90

O “Allan Kardec brasileiro" e o que é Espiritismo ............................................90

As predisposições de Bezerra de Menezes.........................................................99

Sai de cena o homem político; entra o “Apóstolo” do espiritismo .....................105

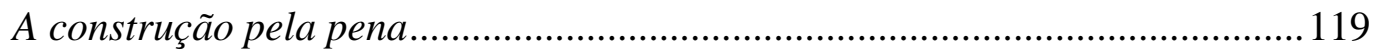

Bezerra veio trazer a paz e não a espada ...................................................... 129

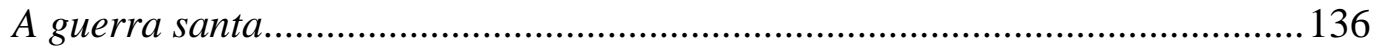

Capítulo III - A produção de um espiritismo religião............................... 150

A matriz do espiritismo religião ................................................................. 150

A “Quarta Revelação"? ............................................................................. 167

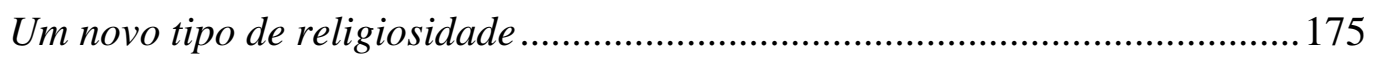


Os estudos espíritas 184

A “Assistência aos Necessitados” 190

A Escola de Médiuns 198

"A fé move montanhas" 204

Considerações finais ............................................................................................. 207

Bibliografia, fontes e biografias ........................................................................ 212

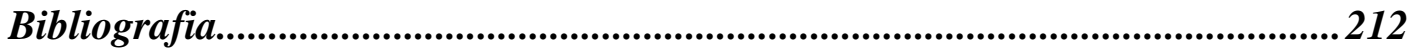

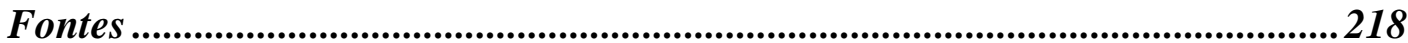

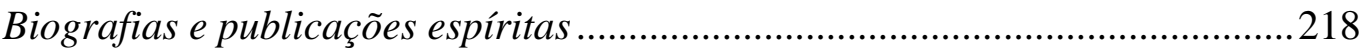

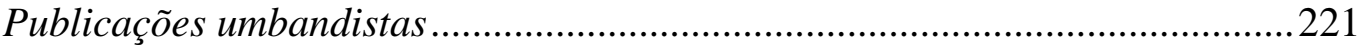

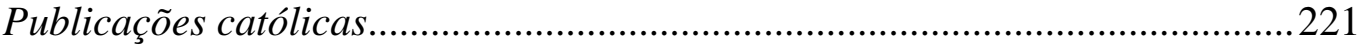

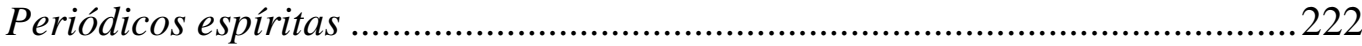

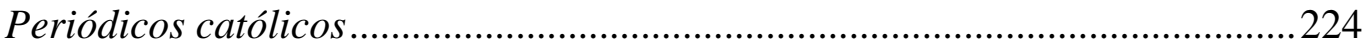

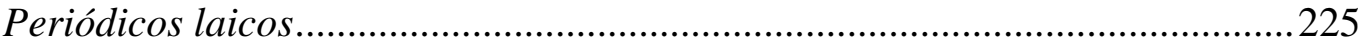

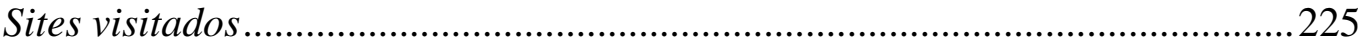




\section{Agradecimentos}

Desde os meus primeiros e muitas vezes vacilantes passos no mundo acadêmico, tive permanentemente ao meu lado um guia (diria mesmo um “espírito-protetor” ou ainda um "anjo-guardião”) que sempre esteve presente, sustentando-me nas freqüentes quedas por que passei ao longo dessa minha empreitada. Posso dizer que sem a presença constante dessa pessoa junto a mim pouco coisa teria conseguido. É por isso que desejo aqui antes de mais nada falar a todos em alto e bom tom, para que ninguém fique sem o saber, que tudo o que eu poderia ter em minha vida, eu já o tenho há anos: Dmitri, meu companheiro inseparável. Há mais de uma década ao seu lado consegui entender e compreender coisas que muitos em toda sua vida não o conseguirão, e mesmo se houver muitas delas, tardarão ainda assim em consegui-lo. Crescemos juntos, e isso foi fundamental. Convivendo ao seu lado, pude ver desabrocharem-se à minha frente novas possibilidades de ser, de agir e de pensar, possibilidades que dificilmente teria podido visualizar se ele não tivesse entrado em minha vida. Descobri com ele esse mundo ao qual pertencemos agora; um mundo que para mim era totalmente novo, mas acima de tudo, enigmático, o que me dava certa insegurança no começo. Não tinha grandes idéias de como lidar com as suas regras e de como era o seu funcionamento. Mas pouco a pouco fui entendendo-o, fui nele me envolvendo e fui gostando do mundo acadêmico. De todos os caminhos possíveis de traçar, esse que tomei foi, com toda a certeza, um dos menos prováveis em minha trajetória; mas creio que é e continuará sendo o mais intrigante, porque me propõe a cada instante desafios mil. Não é à toa que me encontro agora tão enredada nele.

Tenho minhas enormes dúvidas se essa simples palavra pode expressar o imenso agradecimento que devo ao meu amado companheiro; mas pela pobreza do nosso vocabulário e pela falta de outra mais apropriada, vai essa mesmo: muito OBRIGADA!

Quero agradecer também desde já ao meu orientador e amigo, Prof. Dr. Antônio Flávio de Oliveira Pierucci, pelos constantes incentivos e pela 
presença impecável nos meus momentos de dificuldade. Um interlocutor interessado em participar de minhas inquietações e co-autor em vários trechos, sugerindo-me constantemente as melhores direções a seguir. Agradeço, principalmente, pela confiança depositada em mim e no meu trabalho, confiança indispensável para a realização dessa dissertação. Um orientador único que muito me ensinou, principalmente nas entrelinhas de suas falas. Agradeço imensamente não só os vários momentos agradabilíssimos que tive a honra de passar ao seu lado, como também, e sobretudo, as incontáveis risadas proporcionadas por esse espírito gaiato. A você, Flávio, vai também o meu muito obrigada!

Outros ainda fizeram parte dessa minha caminhada, amigos e familiares indispensáveis e que tive a grande sorte de tê-los em minha vida. Agradeço-lhes imensamente tudo o que já fizeram por mim. Minhas tias Alice, Zilda e Regina, que sempre me dispensam mares de ternura. Meu querido e distante irmão Marco Aurélio (que ele consiga realizar o seu sonho, ainda que seja o americano). Minha sogra e amiga Verinha, pessoa a qualquer momento pronta e bem disposta a me auxiliar. Meu digno e prezado sogro Prof. Dr. Normando Celso Fernandes que muito, mas muito mesmo já me incentivou, incentiva-me e tenho a certeza de que continuará me incentivando nesse caminho que resolvi trilhar; uma figura incomparável e generosa que em vários sentidos me enriqueceu com seu vasto conhecimento e sua admirável inteligência, e que nunca, mas nunca mesmo, cobrou-me sequer um décimo do que já me proporcionou, tamanha nobreza de espírito. Minha cara e adorada amiga Rosinha, incomparável pessoa, coração bondoso e afável, que nunca mediu esforços para me ajudar; hoje posso afirmar com toda a certeza: essa pessoa é uma mãe para mim! Meu querido pai, que apesar de distante, vivendo em seu país natal, mora num canto muito especial do meu coração; essa amada figura, com seus costumes arraigados, bebendo diariamente os seus indispensáveis copos de vinho (que no inverno são substituídos pelo "sol y sombra” - bebidas sempre acompanhadas de deliciosas “tapas”), proporcionoume simplesmente a vida que hoje tenho; aliás, nunca mediu esforços para tal, o 
que lhe chegou a custar inclusive a nossa própria distância, uma distância em muitos sentidos; incentivou-me desde pequena a ser autônoma, mas nunca deixou de me acompanhar. E hoje, mesmo entendendo bem pouco, quase nada diria, do que faço, está sempre lá, pronto a me auxiliar, seja no que for preciso. Agradeço-lhe imensamente! E imensamente agradeço também à minha amada e saudosa mãe, responsável por ter me iniciado nos mistérios desta vida. A ela o meu enorme agradecimento e que ela possa, onde quer que esteja neste momento, receber o meu carinho, o meu reconhecimento e a minha enorme admiração. É a você, minha querida mãe, a quem dedico esta dissertação. Afinal, se não fosse você, o sobrenatural para mim continuaria existindo.

Agradeço também a vários amigos, todos eles igualmente importantes, sobretudo nos momentos tão necessários de descontração e de relaxamento (momentos realmente imprescindíveis para a finalização desta dissertação). Quero aqui mostrar minha especial gratidão ao meu querido amigo “generel”, Daniel Bianchi; à Maíra Saruê, uma grande amiga e a quem com muito carinho agradeço todos os momentos compartilhados; a Leonardo Nascimento, baiano arretado; a Maurício Rombaldi e seus deliciosos churrascos; ao agora tão distante colega Flávio Ricardo; e a Rodrigo Rodrigues, ponderado amigo (desejo-lhe muita sorte nessa terra de touros e touradas - ¡Olé!).

Agradeço ao Prof. Dr. Fernando Pinheiro e à Prof. ${ }^{a}$ Dr. ${ }^{a}$ Ana Lúcia Pastore Schritzmeyer, membros da minha banca de qualificação e professores bastante atentos e precisos nos conselhos e na leitura dos meus primeiros escritos. Agradeço também à Prof. ${ }^{a}$ Dr. ${ }^{a}$ Marion Aubrée pelos conselhos e dicas dispensados em benefício da minha pesquisa. Também quero agradecer ao pessoal da secretaria do Departamento de Sociologia, sempre muito prestativos, em especial à Ângela, profissional impecável.

Esta pesquisa foi-me possível graças ao financiamento concedido inicialmente pelo Conselho Nacional de Desenvolvimento Científico e Tecnológico (CNPq) e posteriormente pela Fundação de Amparo à Pesquisa do 
Estado de São Paulo (FAPESP), financiamentos indispensáveis para a realização de meu trabalho e aos quais registro aqui o meu agradecimento. 


\section{Introdução}

Pertence ao senso comum a afirmação de que um "saudável” pluralismo, com as correlatas tendências à tolerância e à mobilidade religiosa, tornou-se a marca da multi-religiosidade brasileira. A existência hoje no Brasil de um grande número de crenças religiosas seria assim caracterizada como um mercado simbólico bastante ampliado, no qual o livre trânsito entre as religiões constituiria apenas uma das feições. Parece que nesse processo as lutas e disputas simbólicas e materiais não fariam parte da dinâmica de um campo religioso. As tensões existentes e os conflitos emergentes nesse campo, contrariando a suposta tolerância às mais diferentes manifestações religiosas, quase nunca são considerados em suas mais diversas faces.

Tendo em vista as premissas teóricas aqui assumidas, isto é, uma investigação sociológica por meio de instrumentos que privilegiam a análise da produção literária e da documentação que registra as tomadas de posição dos intelectuais das religiões em litígio - católicos e espíritas -, pude perceber a existência de um espaço que foi sendo paulatina e exclusivamente destinado à produção de bens simbólicos de salvação. Com efeito, no período que corresponde às últimas décadas do século XIX e início do século XX no Brasil, um campo religioso relativamente autônomo se constitui, muito embora ainda em processo de formação. A dinâmica interna de sua configuração peculiar se expressa na produção literário-midiática dos profissionais religiosos mais atentos, de forma tal que o campo religioso brasileiro já aparece - do ponto de vista que interessa a este trabalho - estruturando-se reflexivamente em torno das disputas simbólicas referidas a ele mesmo, motivadas já por certa dinâmica interna cada vez mais definidamente religiosa.

Ao mobilizar nessa direção os materiais recolhidos e levando-se em consideração a abundância das informações, foi-me possível elaborar com todo o cuidado e razoável segurança uma “explicação” teórica plausível referindo-a à análise empírica das fontes documentais. Dentre os diversos materiais 
utilizados para a identificação das tensões inerentes ao campo estudado, destaco os artigos de jornais e de revistas da época, bem como os livros daquele período - todos religiosos -, biografias, cartas pastorais e cartas abertas dos agentes individuais identificados como principais ou relevantes, vale dizer, os que mais investimentos dispensaram em defesa de suas posições. As informações ali fornecidas auxiliaram-me a demarcar um domínio social específico de tensão e de lutas.

Por conta justamente dessa riqueza inexplorada de fontes, dados e informações contidas no material colhido e ajuntado primeiramente sobre o espiritismo, pude ver aflorar progressivamente sob minhas vistas um campo vasto e quase virgem de análises ${ }^{1}$. Desse modo, quanto mais eu me introduzia

${ }^{1}$ Ao longo deste trabalho, a termo espiritismo será sempre utilizado para designar o corpo teórico-doutrinário criado inicialmente por Allan Kardec, pseudônimo do pedagogo francês Hippolyte Léon Denizad Rivail, na metade do século XIX. É freqüente encontrarmos na literatura acadêmica a utilização do termo espiritismo para indicar mais de um segmento religioso. Nesses escritos, a distinção entre os diferentes segmentos religiosos fica a cargo somente de adjetivos ou de partículas de mesma função que os especificam. Assim, aparecem as designações espiritismo kardecista ou espiritismo de mesa branca, ou ainda alto espiritismo para designar a teoria espírita criada originalmente por Allan Kardec; e espiritismo umbandista ou espiritismo de umbanda ou baixo espiritismo para se referir à religião nascida no Brasil em meados da década de 1920. Aqui, porém, neste trabalho, o termo espiritismo não terá nenhuma relação com a umbanda, em cujo processo de formação teve o termo espiritismo apropriado pelos seus intelectuais, num momento de forte disputa simbólica que tinha como objetivo a entronização da umbanda no campo em que ela passou a atuar. Faço essa ressalva para indicar que os trabalhos da academia, sem o saber (ou pelo menos sem dizer explicitamente), acabaram por empregar em suas análises os termos utilizados pelos próprios agentes sob exame, termos que se referem aos móveis em disputa e que servem para (des)classificar os agentes e/ou grupos no e em jogo. São, portanto, apropriações sem reflexões de uma linguagem êmica - linguagem que dá corpo a uma disputa em cuja dinâmica interna tem como princípio a busca incessante de distinção frente aos demais participantes. Em outras palavras, os pesquisadores, isto é, os sujeitos da objetivação apropriam-se da linguagem dos agentes analisados sem perceberem que a própria linguagem é ela mesma um fator importante a ser levado em conta na especificação do objeto a que se estuda, já que o que está em jogo é o poder legítimo, porque reconhecido, de ditar e de (des)classificar, como se verá mais à frente. 
no exame dos diversos materiais coletados referentes aos primeiros espíritas brasileiros, mais eu percebia o quanto aquele material ainda podia florescer e frutificar na produção de mais conhecimento, e conhecimento novo, a respeito dos anos de formação daquela novíssima religião em terras brasileiras.

Ao longo dos meses de análise foram desabrochando novas descobertas, e perspectivas outras foram surgindo de novas nuances de interpretação dos fatos, personagens e fenômenos que agitaram aquelas primeiras décadas de definição do espiritismo como nova alternativa religiosa, que chegou um momento em que, depois de muito refletir e discutir para bem avaliar a situação que se criara justamente como efeito não previsto de uma pesquisa que estava “dando certo”, decidi que cabia, sim, redimensionar o objeto sob exame. De uma idéia inicial, em que estavam incluídas as análises não só do espiritismo, mas também da umbanda - análises sempre pensadas em relação com o catolicismo -, passei para a análise relacional apenas entre o espiritismo e o catolicismo. Foi assim que parti para remarcar o balizamento do trabalho e o levantamento do material. A decisão de cortar o número de religiões cobertas pelo escopo original da pesquisa deveu-se, portanto, a um fator positivo: a investigação sobre o espiritismo estava indo bem, rendendo acima do esperado. Foi, portanto, por virtude, e não por falta, que tomei a decisão de centrar o foco da pesquisa somente no espiritismo, deixando-se a umbanda para depois.

Desse modo, para a análise do processo de pluralização formal do campo religioso brasileiro de fins do século XIX, passei então a tomar por objeto empírico não mais o desenvolvimento do conjunto da produção literária das religiões denominadas mediúnicas (espiritismo e umbanda), mas sim e apenas o desenvolvimento da produção intelectual dos primeiros espíritas brasileiros e dos seus críticos católicos, podendo assim esmiuçar mais e melhor as características do confronto entre ambas as confissões religiosas. Dessa forma, continuou em vigor o objetivo de entender e explicitar em sua lógica própria o processo de constituição no Brasil de um mercado competitivo de bens de salvação caracterizado pela perda do monopólio religioso da igreja 
católica e pela ascensão da legitimidade institucional das demais religiões. Só que, doravante, com o foco dirigido exclusivamente para a ascensão do espiritismo religioso.

Permaneceu vigente também a intenção de analisar o campo em questão pelo viés dos combates mútuos empreendidos por agentes individuais de destaque, cujas vozes ou penas tornaram o campo religioso um terreno de operação para as lutas entre diferentes empresas de salvação, e não menos entre diferentes faç̧ões da mesma religião. $\mathrm{O}$ abandono da umbanda como objeto não implica, nem de longe, o abandono da minha tentativa de escapar à alternativa simplista da qual são produto as análises mais parciais, ou seja, à oposição entre 1) a ilusão da autonomia absoluta do discurso religioso ou mítico e 2) a teoria reducionista que torna esse discurso o reflexo direto das estruturas sociais. Assim, considero importante repisar que a principal preocupação nas diversas etapas da minha pesquisa foi sempre no sentido de validar o arsenal teórico-metodológico adotado, de olho na consistência do mesmo sem superdimensionar o objeto empírico.

Na decisão de restringir o foco do trabalho ao espiritismo, pesou também a consideração de que os estudos acadêmicos sobre ele no Brasil tendem a explicitar pouco, melhor dizendo, a contemplar de forma insatisfatória uma análise relacional entre os agentes envolvidos na produção e reprodução desse contingente religioso ${ }^{2}$. Além disso, nenhum dos trabalhos mais relevantes que trataram das religiões mediúnicas que começaram a se introduzir no espaço da diferenciação religiosa legítima que se abriu com a Primeira República - diferenciação essa implicitamente hierárquica privilegiou focalizar esse processo histórico como estando determinado por outro processo simultâneo e maior: o da autonomização progressiva da esfera

2 Penso aqui principalmente nos trabalhos de AUBRÉE; LAPLANTINE (1990); CAMARGO (1961, 1973); CAMURÇA (1998, 2001); CAVALCANTI (1983); DAMAZIO (1994); DOYLE (1981); GIUMBELLI (1997a, 1997b, 1998, 2002a); HESS (1987a, 1987b); LEWGOY (2000, 2004); MACHADO (1983); MAGGIE (1992, 1986); SANTOS (1997); SCHRITZMEYER (2004); SILVA, Luiz (2005); STOLL (1999); WARREN $(1984,1986)$. 
religiosa e, conseqüentemente, do processo de constituição de um campo religioso segundo uma lógica tendencialmente concorrencial, que preside a um mercado de bens de salvação, o qual dissolve monopólios ${ }^{3}$. No caso brasileiro, o monopólio era católico.

Nenhum dos estudos feitos até agora se propôs a dar conta, por importante que fosse, de toda uma dinâmica de relações entre as próprias religiões e seus agentes: relações que se dão internamente ao campo religioso e internamente a cada religião. Não examinaram os enfrentamentos ideológicos entre os diversos grupos religiosos e os efeitos disso sobre a própria autonomização de um campo religioso em si. Exatamente por isso não foram capazes de entrever que, se a autonomia da esfera religiosa se dá independentemente da existência de pluralismo religioso, bastando-lhe como condição objetiva que haja uma divisão do trabalho social que incida na vida religiosa como divisão do trabalho religioso ${ }^{4}$ - ainda que tal divisão seja interna a uma só religião - o pluralismo religioso, por sua vez, quando realidade, quando em processo, tem como característica ao mesmo tempo reforçar, consolidar e garantir a reprodução ampliada da autonomia do campo em questão.

Desse modo, a introdução e a aceitação crescente do espiritismo no Brasil serviram para acentuar um movimento mais amplo de pluralização confessional, de que fazem parte outras doutrinas ${ }^{5}$ e sistemas religiosos ${ }^{6}$. É

${ }^{3}$ Refiro-me mais especificamente aqui, além de alguns trabalhos já citados na nota $n^{\circ} .2$, às obras de BROWN (1985, 1997); CONCONE (1987); GIUMBELLI (2002b); NEGRÃO (1994, 1996); ORTIZ (1988).

${ }^{4}$ Cf. BOURDIEU (1974, p. 27-78; 79-98).

${ }^{5}$ Assim, não surpreende que, já no século retrasado, encontremos artigos escritos por espíritas dedicados a responder, para além das investidas católicas, aos ataques de igrejas protestantes do Rio de Janeiro e de São Paulo, enfatizando, não por acaso, seus "ranços" católicos. Cabe destacar, a título ilustrativo, a data de fundação de algumas igrejas protestantes no Brasil: Igreja Evangélica Congregacional, 1855; Igreja Presbiteriana do Brasil, 1859; Igreja Metodista, 1867; Igreja Cristã Evangélica, 1879; Convenção Batista 
assim que, se muito antes da instauração da República brasileira já havia mídia religiosa - pastorais, catecismos, boletins, periódicos, todos católicos -, foi somente com a entrada em cena de novos movimentos e institutos religiosos que este campo passou a se formatar em moldes plurais e a procurar subsistir segundo a lógica de um mercado (desmonopolizado) de bens de salvação cujas estruturas e engrenagens garantem a sua própria existência de acordo com o modelo de um campo relativamente autônomo em sua dinâmica própria de ação e funcionamento.

Para a realização desta pesquisa, foram utilizados dois alicerces centrais. De um lado, esteve sempre presente a necessidade de captar a estrutura das relações possíveis de observar entre os grupos de especialistas leia-se: intelectuais - ocupando também diversas posições homólogas em domínios sociais diferentes e exteriores ao domínio propriamente religioso. Por outro lado, nunca ignorei que somente no interior de cada configuração histórica - nesse caso, durante as últimas décadas do século XIX - podem-se caracterizar exaustiva e rigorosamente as relações entre as diferentes instâncias do campo religioso brasileiro.

Nesse sentido, fiz vários levantamentos quanto à produção especificamente espírita, bem como leituras de documentos adquiridos no acervo da Biblioteca Nacional, no Rio de Janeiro. Lá estão arquivados vários

Brasileira, 1882; Igreja Adventista do Sétimo Dia, 1894. Vale assinalar que antes dessas igrejas, os anglicanos e os luteranos já haviam se introduzido no espaço da diferenciação religiosa no Brasil, os primeiros em 1808 e os segundos em 1824 (FERNANDES, Rubem, 1992).

${ }^{6}$ Após um período no qual - já sob a República laica - introduziram-se por via imigratória crenças de grupos de imigrantes (japoneses, judeus, sírio-libaneses e outros), além de novas denominações protestantes, o ciclo complementar-se-ia no decorrer do século XX com a disseminação de novas filosofias e a difusão dos assim chamados cultos afrobrasileiros, antes confinados a comunidades isoladas. Hoje, são muitas as crenças e as filosofias religiosas abraçadas pela população brasileira, enfraquecendo-se com isso a antiga hegemonia católica e fortalecendo, assim, o pluralismo religioso, fator que tem se mostrado indispensável para a garantia da autonomia do campo em questão. 
periódicos da época, inclusive documentos religiosos, sobretudo espíritas, tais como revistas, jornais e livros. Além deles, há também uma grande gama de cartas pastorais episcopais e outros materiais impressos católicos que em muito me auxiliaram no desenvolvimento da pesquisa. Todos os números do Reformador, por exemplo - órgão oficial da Federação Espírita Brasileira -, como também as demais produções espíritas da época, por mais efêmeras que tenham sido, estão arquivados nessa biblioteca. As reproduções presentes neste relatório fazem parte desse acervo. Além disso, pesquisei também o conteúdo de inúmeros sites específicos e especializados em espiritismo, locais privilegiados de dados e de informações históricas e sociais, bem como os acervos de algumas agremiações espíritas. Todos os passos da pesquisa foram planejados e realizados sempre tendo em vista a sua finalidade maior: desenhar da melhor forma possível as linhas de forças de um campo de agências religiosas com seus principais personagens que foi se tornando relativamente autônomo no Brasil e cada vez mais heterogêneo.

Mas embora tenha conseguido contatar um número razoável e variado de materiais, julguei sempre necessária certa atenção crítica na análise do conteúdo neles exposto. Digo isso porque em sua grande maioria essa documentação foi pensada e elaborada por ninguém menos do que os próprios participantes do e em jogo nas disputas simbólicas que constituem o objeto deste trabalho. Daí o cuidado sempre presente em lidar com informações extremamente enviesadas, produto de investimentos pesados de agentes totalmente mergulhados nesse processo. Justamente pela natureza mesma dessa literatura, pareceu-me que o caminho mais seguro a tomar fosse o de confrontar constantemente os mais diversos dados e fatos aí apresentados sempre com o auxílio da bibliografia acadêmica, além de prosseguir metodologicamente com base em uma proposição teórica que clama incessantemente pela permanente observação crítica e reflexiva tanto do objeto em questão quanto do próprio sujeito da objetivação. E isso tudo com a finalidade de não ser também eu tragada por essa maré de lutas intestinas, interesses exclusivistas e participações ardorosas que impeliram as ações e tomadas de posição dos 
produtores desses bens simbólicos. Mas por outro lado e sem dúvida alguma, foi exatamente por conta da natureza dessa documentação, produzida pelos próprios agentes envolvidos na disputa, que pude ver e entrever as direções que eles tomavam ou as tendências que demonstravam, num movimento contínuo de avanços e recuos, fluxos e refluxos.

Os passos seguidos para a realização desta pesquisa se deram, portanto, da seguinte forma: 1) mapear o conjunto de instâncias e lugares sociais no interior do espiritismo, a fim de compor um retrato dos móveis internos de jogo e competição; 2) reconstruir a hierarquia interna em cujas posições se dispunham atores e obras, focalizando os móveis capazes de atiçar a concorrência com outras religiões no âmbito do campo religioso brasileiro em formação; 3) buscar mobilizar um "retrato” da dinâmica histórica dos processos sob exame.

Ainda sobre o método, pareceu-me imprescindível a análise das biografias dos agentes que foram compondo pouco a pouco, através de suas ações, um meio específico de atuação. Mas, se de um lado elas foram fundamentais para a compreensão desse processo, de outro, demandaram certos cuidados sobre os quais tive que focar minha atenção. Porque se pensarmos na biografia de cada um, podemos correr o risco de cair na significação dos casos isolados e chegaremos à conclusão inoperante de que nenhum agente é igual ao outro. Pois ao respeitarmos sem restrições a integridade do agente, desistimos de entendê-lo ou, o que é pior, acabamos por lhe dar capacidades extraordinárias, acentuando demasiadamente a sua individualidade, como se ele estivesse despregado do mundo social e despossuído de toda e qualquer determinação ou predisposição. No entanto, se subirmos ao raciocínio mais genérico, dissolvendo os agentes nas categorias de classificação, conseguiremos até manipular a realidade com certo êxito, mas acabaremos atropelando por demais a verdade singular. Essa operação que consiste em descrever a trajetória de cada um tentando conciliá-la com o significado que ela acaba adquirindo no processo histórico se mostrou a mim um tanto quanto 
delicada e muitas vezes difícil de realizar. Mas acredito que seja este o desafio de fazer sociologia, e uma sociologia que leva em conta não só os agentes, mas acima de tudo as relações objetivas que estabelecem. 


\section{Capítulo I - A "Reforma" espírita}

\section{Espiritismo, o termo de distinção}

Espectros rondavam a Europa, e dessa vez não era o espectro do comunismo. Mesas giravam e barulhos estranhos eram ouvidos por pessoas que se reuniam em sessões de entretenimento justamente para ver o espetáculo. Uma onda de novidades extra-cotidianas pairava na Europa do século XIX, sobretudo em terras francesas. E mesmo Karl Marx, arredio a tais crenças, não pôde deixar de mencionar o fenômeno das "mesas", ainda que em nota de rodapé:

Depois da derrota das revoluções de 1848/49 começou na Europa um período de mais obscura política reacionária. Enquanto, nesse tempo, as rodas aristocráticas e também as burguesas se entusiasmaram pelo espiritismo, especialmente por fazer a mesa andar, desenvolveu-se na China um poderoso movimento de libertação antifeudal, [...]. (MARX, 1988, p. 70, grifos nossos).

Irônico é notar que tal referência tenha aparecido justamente no tópico intitulado $O$ caráter fetichista da mercadoria e sua fantasmagoria. Um grande divertimento para uns, um grande enigma para outros; o fenômeno das "mesas girantes e falantes” reunia freqüentadores dos salões de toda a Europa em busca de mensagens obtidas a partir das pancadas produzidas por objetos que pareciam obedecer a alguma força desconhecida e autônoma.

Formas de religiosidade mística se desenvolviam naquele momento, paralelamente a idéias cientificistas e positivistas, como as de Auguste Comte. Em meio a esses dois pólos encontrava-se Allan Kardec, pseudônimo do pedagogo francês Hippolyte Léon Denizad Rivail, reconhecido por espíritas e não-espíritas como o codificador $^{7}$ de um corpo teórico filosófico-religioso-

\footnotetext{
7 Os termos "codificador" e "codificação", que serão utilizados várias vezes ao longo deste trabalho, são apropriações da linguagem êmica espírita. Allan Kardec é tido como o
} 
científico, que parte de pressupostos indiscutíveis, tais como a imortalidade da alma, a pluralidade das vidas e a existência de Deus. Agente social inserido em uma configuração específica, na qual Comte e Marx desenvolviam suas teses, o primeiro deles com grande repercussão, Kardec não pretendia contrariar as descobertas do campo da ciência, mas também não ficou ileso das influências da onda espiritualista do momento. Partiu então de uma premissa: “o sobrenatural não existe” 8 . Esse pressuposto erguido por Kardec e sustentado por seus seguidores define muito do que seria a sua abordagem dos fenômenos psíquicos e mediúnicos em sua teoria:

O pensamento é um atributo do Espírito. A possibilidade de agir sobre a matéria, de impressionar os nossos sentidos, e portanto de transmitir-nos o seu pensamento é uma conseqüência, podemos dizer, da sua própria constituição fisiológica. Não há, pois, nesse fato, nada de sobrenatural, nada de maravilhoso. [...] Não obstante, dirão, admitis que um Espírito pode elevar uma mesa e sustentá-la no espaço sem um ponto de apoio. Isso não é uma derrogação da lei da gravidade? - Sim, da lei conhecida; mas a Natureza já vos disse a última palavra? Antes das experiências com a força ascensional de certos gases, quem diria que uma pesada máquina carregando muitos homens poderia vencer a força de atração? Aos olhos do vulgo isso não deveria parecer maravilhoso, diabólico? (KARDEC, 1998, p. 19)

Negando assim a existência do sobrenatural, o espiritismo poderia então ser enquadrado como uma nova ciência com seus próprios métodos positivos, uma vez que o seu objeto não era a matéria, mas o espírito. Ele "codificador do espiritismo" porque foi dele o trabalho de organização e de sistematização dos conteúdos da teoria espírita. Isto é, Allan Kardec "codificou", segundo os espíritas, as mensagens ditadas pelos "espíritos" em cinco livros denominados "livros da codificação". Codificar (do latim, codice + fic, variante de facere) significa: 1) reunir normas em forma de código; 2) compilar; 3) coligir; 4) transformar em seqüência de sinais adequados a determinados códigos. É nesse sentido que os espíritas titulam Allan Kardec de "o codificador do espiritismo".

${ }^{8}$ Frase legada por Allan Kardec e proferida no discurso de Camille Flammarion no momento de seu enterro (KARDEC, 1993, p. 18-28). 
lidaria, portanto, com o estudo dos "problemas espirituais" e com as diversas formas de manifestação dos espíritos.

Como meio de elaboração, o Espiritismo procede exatamente da mesma maneira que as ciências positivas, isto é, aplica o método experimental. Fatos de ordem nova se apresentam, que não podem ser explicados pelas leis conhecidas; ele as observa, compara, analisa e, partindo dos efeitos às causas, chega à lei que os rege; depois deduz as conseqüências e busca as aplicações úteis. O Espiritismo não estabeleceu nenhuma teoria preconcebida; assim, não se apresentam como hipótese nem a existência e a intervenção dos Espíritos, nem o perispírito, nem a reencarnação, nem qualquer dos princípios da doutrina; conclui-se pela existência dos Espíritos porque essa existência resultou como evidência da observação dos fatos; e assim os demais princípios. Não foram os fatos que vieram posteriormente confirmar a teoria, mas foi a teoria que veio subseqüentemente explicar e resumir os fatos. É rigorosamente exato, portanto, dizer que o Espiritismo é uma ciência da observação e não o produto da imaginação. As ciências não fizeram progressos sérios senão depois que os seus estudos se basearam no método experimental; mas acreditava-se que esse método não poderia ser aplicado senão à matéria ao passo que o é igualmente às coisas metafísicas. (KARDEC, 2001a, p. 16, grifos do autor)

Contrário às corporações místicas e teosóficas de sua época e contrário a todas as ordens ocultas que deslocavam o “problema do espírito” para o terreno do mistério, Kardec buscou, portanto, relacioná-lo à ciência, sempre a pensando como um procedimento racional de observação e conclusão.

Repetimos ainda que, se os fatos de que nos ocupamos estivessem reduzidos ao movimento mecânico dos corpos, a pesquisa da causa física do fenômeno seria do domínio da ciência; mas desde que se trata de uma manifestação fora do domínio das leis humanas, escapa à competência da ciência material porque não pode ser explicada por números, nem por forças mecânicas. Quando surge um 
fato novo, que não se enquadra em nenhuma ciência conhecida, o sábio, para o estudar, deve fazer abstração de sua ciência e dizer a si mesmo que se trata de um estudo novo, que não pode ser feito através de idéias preconcebidas. (KARDEC, 2001a, p. 37)

Todas as idéias, portanto, filiam-se a uma história, a um contexto, no sentido de sítio abrangente de ocorrências motivadas, e as de Kardec, segundo este ponto de vista, não poderiam ser diferentes. Pois bem, partindo dessa prerrogativa, os estudos sobre o nascimento do espiritismo são quase unânimes em asseverar as muitas relações existentes entre o seu surgimento e as idéias positivistas e evolucionistas, de uma parte, bem como suas relações com os ideais socialistas e republicanos, de outra ${ }^{9}$. Desse modo, se de um lado a compreensão do aparecimento do espiritismo quando atrelada apenas ao estudo do contexto francês do século XIX é capaz de dar conta de uma série de reflexões pertinentes e esclarecedoras desse processo, por outro, paradoxalmente, não consegue perceber que o espiritismo, inserido em outras situações, toma um caráter se não total, pelo menos parcialmente distinto do espiritismo original. Porque não basta situar uma ação, ou seja, identificá-la num determinado espaço e num determinado momento - o que de fato pode sim dar bons resultados. É preciso, acima de tudo, identificar também quem são os agentes que lhes dão materialidade, a partir de qual lugar no espaço social eles o fazem e quem são os grupos que lhes rendem reconhecimento.

Posto isso, fica mais claro entender a literatura acadêmica de hoje sobre o espiritismo. Os trabalhos que discutem a questão do seu surgimento no Brasil podem ser divididos em dois grandes grupos. De um lado, temos os autores que procuram explicar as singularidades brasileiras do espiritismo como deturpações dos princípios originalmente estabelecidos na França; de outro lado, estão os autores que o enxergam como uma reconstrução original do original.

\footnotetext{
${ }^{9}$ Este é o caso de AUBRÉE; LAPLANTINE (1990).
} 
Os autores do primeiro grupo enfatizam a hipótese de que na França o espiritismo possuía um caráter mais filosófico e/ou mais científico, diferentemente do espiritismo brasileiro, no qual o lado religioso hoje nos salta aos olhos - hoje, notar bem. Argumenta-se que tal fato deve-se ao “misticismo da tradição cultural brasileira”. Essa é a opinião de Ubiratan Machado (1983) em seu livro Os intelectuais e o espiritismo, por exemplo. Tanto para Machado quanto para François Laplantine e Marion Aubrée (1990), dupla de autores do livro La table, le livre et les esprits (que também compartilham da visão acima), o processo de “abrasileiramento” do espiritismo levou-o a uma perda do caráter científico, o que corresponderia a um “abastardamento” do movimento espírita francês.

Há, por outro lado, autores mais precisos como Jaqueline Stoll (1999) e Emerson Giumbelli (1997a), que nas obras Entre dois mundos e O cuidado dos mortos respectivamente, além de Sylvia Damázio (1994), em Da elite ao povo, vêem o espiritismo como uma reconstrução original. Giumbelli propõe-se a compreender o espiritismo como um "rótulo" que teria se formado e se estabelecido através de processos históricos externos à dinâmica do campo religioso. Para ele, o espiritismo brasileiro teria sido moldado e constituído através das injunções repressivas de ordem policial e judiciária pelas quais se viu constrangido a passar. Já Stoll afirma que o espiritismo brasileiro teria sofrido um processo de reinterpretação ao chegar ao Brasil; noutras palavras, ele consistiria numa reconstrução original influenciada pela formação cultural brasileira. Para ela, as diferenças apresentadas por uma mesma religião em lugares diversos são o resultado de estratégias sociais especificamente regionais, que buscam resolver o dilema: adaptação versus preservação dos princípios. Sylvia Damázio, por sua vez, enfatiza as disputas internas entre agentes espíritas em busca da construção do que passaria a ser o que conhecemos como espiritismo. Portanto, ela também entende o espiritismo como uma construção original possibilitada pelas especificidades históricosociais brasileiras de lutas e confrontos entre grupos sociais. Assim, longe de ser uma simples deturpação dos princípios originais, conforme postula o 
primeiro grupo de analistas, o espiritismo não poderia ter mantido sua “pureza”, já que teve que responder a imperativos históricos, sociais e culturais distintos.

Entretanto, todos os trabalhos até agora analisados contemplam de forma insatisfatória, salvo melhor juízo, os mecanismo de criação do espiritismo no Brasil - e na França também -, uma vez que deixam de lado uma análise relacional entre os agentes envolvidos na produção e reprodução desse contingente de idéias e postulados. Sendo assim, não conseguem captar as especificidades de um domínio em formação através, principalmente, da análise da ação desses agentes, que estariam dispostos em uma espécie de campo de forças, como se fossem partículas a se movimentarem em função das demais. Seus investimentos nesse jogo, produto de suas trajetórias e de suas disposições, influenciariam definitivamente o processo em questão. Mas para uma melhor compreensão disso tudo, retornemos à França oitocentista.

É sabido que as principais teorias e concepções científicas do século XIX francês, o positivismo, o evolucionismo, o marxismo, tiveram a marca do legado Iluminista, ao mesmo tempo progressista, racionalista e experimental. A imagem do mundo projetada por esta cultura científica não contemplava a possibilidade de qualquer realidade fora do domínio "material” que não pudesse ser explicada através de experimentos laboratoriais, de verificações racionais de suas causas e do controle de suas variáveis, sobretudo por meio de cálculos e de comprovações das leis que regem os fenômenos naturais, físicos, biológicos e até mesmo sociais. O Iluminismo, nesse sentido, havia assumido sua feição intelectual mais vigorosa nesta nação, influenciando os diversos sistemas de pensamento nela desenvolvidos, daí a asserção de ser o espiritismo seu herdeiro direto. Mas se assim é, ou seja, se o espiritismo é herdeiro direto do Iluminismo, ele somente o é por intermédio, ou melhor, pela atuação e pelo trabalho de um, digamos, "iluminista-tardio". Desse modo, em vez de tratar o espiritismo em si como uma teoria nascida a partir e/ou no meio de tantas outras, uma análise rearticulada do ponto de vista do agente, de suas relações e 
de suas práticas evitaria tomar as atividades levadas a cabo por Hippolyte Léon Denizard Rivail, isto é, Allan Kardec, como simples resultante mecânica de um contexto. A prática da construção da teoria espírita desenvolver-se-ia, portanto, na lógica das interações sociais e dela derivaria seus cálculos, estratégias e previsões. Essa lógica envolveria a ativação dos repertórios simbólicos disponíveis e dispostos na trajetória singular do agente atuante, neste caso, de Allan Kardec. Por isso, os recursos a partir dos quais Kardec interpretou a situação eram sim coletivos, mas foram selecionados por ele segundo seu cabedal e de acordo com seus próprios capitais.

Nascido em Lyon em 1804, Hippolyte Léon Denizard Rivail ${ }^{10}$ recebeu seus primeiros estudos na sua cidade natal e completou-os no famoso Instituto de Educação Pestalozzi, em Yverdon, Cantão de Vaud, na Suíça. Lá, ele teria adquirido o hábito da investigação e da liberdade de pensamento, qualidades que iriam ser exibidas posteriormente em sua vida. Afeito pelo ensino, revelouse em pouco tempo um dos discípulos mais fervorosos do pedagogo suíço cujas inspirações partiram, sobretudo, das doutrinas de Jean-Jacques Rousseau. Anos mais tarde, Rivail criaria, em Paris, o primeiro instituto no gênero daquele de Yverdon.

O estabelecimento de Pestalozzi recebia alunos de todas as partes da Europa e administrava uma educação liberal fundada na confiança e no desenvolvimento individual e gradual de cada aluno, abandonando deste modo qualquer tipo de punição física ou moral. O jovem Rivail foi então envolvido por esse sistema de conhecimento, aprendendo entre outras coisas, os idiomas alemão, inglês e holandês. Levantava-se às quatro e meia da manhã para estudar e para praticar, segundo a expressão de Pestalozzi, "l'école mutuelle”, sistema no qual os alunos mais velhos ensinavam os mais jovens. Foi assim que

10 Os dados biográficos de Allan Kardec podem ser encontrados em WANTUIL (2002); THIESEN; WANTUIL (1998, vols. I, II, III). 
começou o seu trabalho de professor, desde o início seguindo os passos de seu mestre, que representava para ele o exemplo mor de educador.

Como Pestalozzi, Rivail também acreditava sobremaneira em uma ciência da educação, fundamentada a partir da "natureza humana” e não a partir de crenças sobrenaturais. Ela seria a pedra de toque da evolução harmoniosa da humanidade e beneficiaria igualmente homens e mulheres. A educação, nesse sentido, regeneraria o homem, livrando-o, portanto, das misérias sociais e individuais.

A instrução de uma criança não consiste apenas na aquisição desta ou daquela ciência, mas no desenvolvimento geral da inteligência; a inteligência se desenvolve na proporção das idéias adquiridas, e quanto mais idéias se tem, mais apto se é a adquirir novas. A arte do professor consiste na maneira de apresentar estas idéias, no talento segundo o qual ele sabe graduá-las, classificá-las e apropriá-las à natureza da inteligência. Como o hábil jardineiro, ele deve conhecer o terreno em que semeia, pois o espírito da criança é um verdadeiro terreno cuja natureza é preciso estudar; e assim como o talento do jardineiro não se limita a saber colocar plantas na terra, assim o do professor não se limita a fazer aprender os rudimentos. Durante muito tempo, este papel passivo e mecânico pareceu ser o dos homens destinados a formar a juventude e os aparelhos de castigo que eram vistos como inseparáveis de suas funções, eram pouco apropriados a elevá-los na opinião pública. Mas hoje começamos a compreender que eles têm uma missão mais nobre; que para ser um bom professor não lhe basta saber fazer versos latinos, que o pedantismo é o ridículo desta condição.

Para bem ensinar, é preciso conhecimentos especiais, independentemente da ciência que se queira transmitir; é preciso conhecer a fundo a natureza do espírito das crianças, a ordem e a maneira segundo as quais se desenvolvem as faculdades, as modificações da inteligência segundo a idade, as relações entre o físico e o psíquico; o efeito das influências exteriores, as causas que 
podem apressar ou atrasar o desenvolvimento das faculdades; as doenças do espírito, se assim posso me exprimir; a ordem segundo a qual nascem as idéias, a maneira pela qual se encadeiam, aquelas que devem servir de fundamento às outras; calcular a força do espírito e a possibilidade de conceber tais ou quais idéias; conhecer enfim os meios mais próprios a desenvolvê-las. Mas isto ainda não basta; é preciso ainda um tato particular, inato por assim dizer; uma arte que não se aprende. Vê-se pois que a ciência do professor é toda filosófica, e que ela exige muitos estudos da parte daquele que se lhe entrega. Estou longe de ter traçado nessas poucas palavras um quadro completo da ciência pedagógica; toquei-a apenas de leve, pois o detalhamento de todos os conhecimentos que ela abrange seria imenso. $^{11}$

Assim, através da mediação de Pestalozzi, certas influências de Rousseau e da filosofia do século XVIII vão formar o espírito de Rivail e servir de modelo para o espiritismo, entre outros pontos, os ideais de tolerância, fraternidade e universalidade. Além disso, como Rivail havia pertencido à geração dos socialistas utópicos decepcionados pelos fracassos da revolução de 1848, buscava, como eles, a transformação da sociedade por outros meios para além da luta política, daí a educação como via possível.

Em um artigo póstumo que a Revue Spirite publicou no dia seguinte de sua morte, Kardec reconhecia sua dívida com relação aos três autores: Jean Reynaud, Charles Fourrier e Eugène Sue. Socialistas que se tornaram espíritas - mas nem todos os espíritas eram socialistas -, todos eles atuavam no sentido de melhorar as condições de vida dos trabalhadores. Basta consultar a impressionante soma de obras socialistas dessa época para ver como esses diferentes temas - a justiça, o progresso, a reencarnação, a igualdade - estavam

11 Disponível em: <http://www.espirito.org.br/portal/artigos/verdade-e-luz/textospedagogicos-de-rivail.html > Acesso em: 14 maio 2008. Esse excerto foi extraído, segundo o site acima, do livro de RIVAIL, Hippolyte Léon Denizard. Textos pedagógicos. São Paulo: Comenius, 2000. 
estritamente imbricados, incrustados mesmo. Interessante notar que a teoria da reencarnação já era, antes de Kardec, compartilhada pela maior parte dos socialistas utópicos (AUBRÉE; LAPLANTINE, 1990). Fossem seguidores de Fourier, fossem seguidores de Saint-Simon, eles tinham a convicção de que a sede de justiça e de igualdade seria sanada no futuro. Sua confiança no além e num porvir melhor era absoluta, e foram eles que, contribuindo indiretamente com a elaboração do espiritismo, se reconheceram naturalmente nele anos mais tarde. Kardec, na realidade, não freqüentava pessoalmente o meio socialista; entretanto, teve contato com todas as idéias provindas deste entorno, entre as quais a teoria da reencarnação, sendo dela muito afim ${ }^{12}$. Tem-se a título de exemplo as obras de Alphonse Esquiros, L'Évangile du peuple (1840) e De la vie future du point de vue socialiste (1850); de Jean Reynaud, Terre et ciel (1854), na qual ele defende a imortalidade da alma e o ciclo das reencarnações; de Eugène Sue, Mystères de Paris (1842); de Henri Lecouturier, La

\footnotetext{
${ }^{12}$ A idéia de reencarnação era na França, mas sobretudo na Inglaterra, o ponto mais candente da divisão entre os chamados espiritualistas e os espíritas. No livro de Arthur Conan Doyle (1981), essa querela está bem documentada. Lê-se, por exemplo, à página 323: "L'Hon Alexandre Aksakof, dans un interéssant article fournit les noms de médiums du cercle de Allan Kardec, avec um rapport à leur sujet. Il souligne aussi que la croyance dans l'idée de réincarnation était fort en France à cette époque, comme on peut le constater entre autre à partir de l'ouvrage de M. Pezzani, The Plurality of Existances. Aksokof écrit: 'll est claire que la propagation de cette doctrine par Kardec était une question de forte prédilection; dès le debut, la réincarnation n'a pas été presente comme un object d'étude mais comme un dogme. Pour le soutenir, il a toujours eu recours à de médiums à ecriture qui, c'est bien connu, passent très facilement sous l'influence psychologique des idées préconçues; et le spiritisme en a engendre à profusion; alors que, par les médiums phsyque, les comunications ne sont pas seulement plus objectives mais toujours opposées à la doctrine de la réincarnation. Kardec prit le parti de toujours déprécier cette categorie de médiums prétextant leur infériorité morale. Ainsi la méthode expérimentale est absolument inconnue dans le spiritisme français et pendat vingt ans il n'a pas fait le plus petit progrès intrinsèque et est demeuré dans l'ignorance totale du spiritualisme anglo-américain! Les quelques médiums phsyque français qui ont développé leurs pouvoirs malgré Kardec ne furent jamais cites par lui dans la Revue [Revue Spirite fundada por Allan Kardec]; ils restèrent presque inconnus des spirites et cela uniquement parce que leurs esprits ne soutenaient pas la doctrine de la réincarnation'."
} 
cosmosophie ou le socialisme universel (1850); de Victor Considérant, Le socialisme devant le Vieux Monde ou le vivant devant les morts (1849); de Charles Fourier, Théorie des quatre mouvements, na qual compartilha da teoria reencarnacionista, e em seguida dela, e mais profundamente trabalhada, a obra Théorie de l'unité universelle, onde o tronco fundamental do pensamento de Charles Fourier é retomado, além de aprofundado o seu projeto de transformar a civilização (explorada, oprimida e pobre) em uma sociedade harmoniosa (liberta e igualitária).

Uma vez radicado em Paris, na década de 1820, Rivail começou a escrever uma série de obras de cunho pedagógico, umas voltadas às ciências exatas e naturais, outras à gramática francesa, além de verter para o francês alguns livros estrangeiros. Muitos de seus manuais (assinados "Hippolyte Léon Denizard Rivail, discípulo de Pestalozzi”) foram adotados pela Universidade francesa. Todos eles propunham uma renovação dos métodos de educação dando uma importância expressiva à educação moral, resquícios da leitura de Emílio - ensaio pedagógico sob a forma de romance de Jean-Jacques Rousseau. Eram obras sem nenhum caráter religioso. Pelo contrário, elas estavam impregnadas de um espírito positivo. Além disso, sua ambição era acima de tudo universalista.

Provindo de uma família de juristas e sendo o que se pode classificar de burguês liberal, o que significava naquela época também ser anticlerical, e especificamente no caso de Rivail, contrário ao poder e às concepções dos jesuítas sobre educação, era quase inevitável que não estivesse mergulhado nos ideais de liberdade, igualdade e fraternidade. Não foi à toa que Rivail fora enviado à Yverdon para completar os seus estudos. Sua família, como as demais da mesma camada social, queria mesmo afastar seu filho das influências de um catolicismo bastante conservador, já que naquela época a maior parte das instituições educacionais francesas era católica.

Talvez por conta de toda a sua trajetória de formação social e educacional laica, a sua aproximação com as comunicações obtidas naquelas 
sessões das "mesas girantes e falantes" tenha sido carregada de certo ceticismo num primeiro momento. Mas também por conta dessa mesma trajetória, o seu trabalho de formatação e de organização de todas as mensagens "fornecidas pelos espíritos e recebidas pelos médiuns" ${ }^{\text {13 }}$ foi dotado de uma coerência interna, retratada sobretudo em Le livre des esprits, de 1857. Após o início de seu trabalho de sistematização - que começou como um favor a um grupo de amigos composto, entre outros, por Tiederman, professor de zoologia e anatomia da Universidade de Heidelberg, René Taillandier, seu aluno e membro da Académie des Sciences, o dramaturgo Victorien Sardou e o editor Didier -, a "missão" de Rivail é revelada por seu "guia espiritual”, ninguém menos que o Espírito da Verdade, momento em que passa a adotar não só o pseudônimo de Allan Kardec, mas passa a ser simbolicamente Allan Kardec, um novo indivíduo na história. Essa "missão" - bem como a de todos os que dela são encarregados em algum momento do desenvolvimento do espiritismo -, acreditada por ele e por todos os seus companheiros e seguidores, agregava em Kardec e em toda sua obra um valor simbólico bastante eficaz. Isso porque à medida que tal fato conservava, ou melhor, assegurava a crença no missionário e em sua própria "missão”, fornecia-lhe também os princípios de sua "ética profissional", sobretudo a recusa absoluta de qualquer interesse no reconhecimento alheio de sua própria obra.

Na capa do Livre des esprits estava registrado o nome do seu codificador, quer dizer, o seu pseudônimo, Allan Kardec. Rivail preferiu colocar este nome em sua mais importante obra, talvez para diferenciar sua temática daquelas de suas obras anteriores, voltadas à educação e à pedagogia. Mas a pergunta curiosa que se coloca é a seguinte: por que Allan Kardec? Segundo as diversas biografias a ele dedicadas, certa ocasião um espírito, que se denominava $Z$, havia dito a Rivail que eles tinham sido amigos numa vida anterior; ambos teriam vivido entre os Celtas Druidas, nas Gálias, e o nome de

${ }^{13}$ Segundo o espiritismo, médiuns são indivíduos cujas faculdades encerram as funções de receber e transmitir as mensagens dos espíritos. 
Rivail, na ocasião, era, pois, Allan Kardec. Foi por isso que resolveu adotá-lo como pseudônimo.

Uma vez o livro codificado e acabado, em meados de 1856, um novo problema se colocou ao missionário: a sua publicação. Os editores consultados, incluindo o próprio Didier, que momentos antes insistira para que Kardec organizasse as mensagens dos espíritos, recusaram-se a publicá-lo com o argumento de que era uma obra sem futuro e, além disso, escrita por um autor cujo pseudônimo era totalmente desconhecido. Somente em 18 de abril de 1857 Le livre des esprits sairia pela Tipografia De Beau em Paris ${ }^{14}$. Entretanto, contrariando as previsões editoriais, o livro conheceu um rápido e inimaginável sucesso. Foi reeditado quinze vezes enquanto Kardec esteve vivo, isto é, até 31 de março de 1869 (AUBRÉE; LAPLANTINE, 1990, p. 30). Contudo, o conteúdo completo do livro com o qual nos deparamos hoje foi publicado somente em 1860, ocasião de sua segunda edição, “inteiramente refundida e consideravelmente aumentada”, conforme anunciava sua página de rosto. Passou a conter 1019 perguntas e respostas distribuídas em quatro partes, enquanto que a anterior, de 1857, tinha apenas 501, divididas em três partes.

Dos meios operários ao Palácio das Tulherias ${ }^{15}$, foram muitos os olhares que se voltaram para o livro. Entretanto, foi primeiramente a classe trabalhadora - la classe ouvrière - que mais se identificou com a obra, comprando-a e fazendo dela seu livro de cabeceira (IDEM, p. 30; 36; 71-81). É

14 "No dia 18 de abril de 1857, pela manhã, foram entregues pela Tipografia De Beau, à Livraria Dentu, na Rue Montpensier, defronte da Galeria d'Orléans, no Palais Royal, em Paris, O Livro dos Espíritos, e, à tarde, quando Kardec chegou à livraria, o Senhor Clément, gerente da mesma, o abraçou satisfeito e the disse: os livros chegaram e já foram vendidos mais de $\mathbf{5 0}$ volumes, até agora. O Barão Du Potet, comprou dois exemplares e George Sand também levou dois exemplares: um para ela, e outro para Victor Hugo." (ABREU, 1996b, p. 41-69, grifos do autor).

${ }^{15}$ Depois do lançamento do Livro dos espíritos, o imperador Napoleão III chegou mesmo a solicitar a presença do professor Rivail, que a essa altura passava também a ser conhecido como Allan Kardec, para Ihe fazer questões pertinentes a seu livro (AUBRÉE; LAPLANTINE, 1990). 
por isso que vem bem a calhar a afirmação de Marion Aubrée e de François Laplantine (IBIDEM) de que o pedagogo dos jovens parisienses transformarase, a partir de então, em educador do gênero humano e, mais particularmente, da classe operária.

Desde o início, Kardec esteve preocupado em distinguir sua teoria das demais em voga, não só criando concepções novas com relação à ciência e à religião, mas também inovando o vocabulário, já que:

Para coisas novas necessitamos de palavras novas, pois assim o exige a clareza de linguagem, para evitarmos a confusão inerente aos múltiplos sentidos dos próprios vocabulários. As palavras espiritual, espiritualista, espiritualismo têm uma significação bem definida, dar-lhes outra, para aplicá-las à Doutrina dos Espíritos, seria multiplicar as causas já tão numerosas de anfibologia. [...] Em lugar das palavras espiritual e espiritualismo empregaremos, para designar esta última crença as palavras espírita e espiritismo, nas quais a forma lembra a origem e o sentido radical, e que por isso mesmo têm a vantagem de ser perfeitamente inteligíveis, deixando para espiritualismo a sua significação própria. (KARDEC, 2001a, p. 24, grifos do autor)

Sua construção terminológica, um recurso técnico e pedagógico que visa uma linguagem mais clara, se visto superficialmente, carregava uma forte marca distintiva em relação a todo o "movimento espiritualista" que teria se originado nos Estado Unidos em $1848^{16}$ e se difundido pela Europa anos mais tarde. Sobre esse aspecto, essa construção pode significar muito mais, pois que

${ }^{16}$ Historicamente, para os espíritas e espiritualistas, o espiritualismo moderno, ou movimento espiritualista, teria surgido e sido motivado pelos fenômenos de movimentação de objetos e de pancadas, verificados primeiramente nos Estado Unidos em 1848. O marco de tais acontecimentos ocorreu na aldeia de Hydesville, no condado de Wayne, na casa da família Fox, cujas filhas, Katherine e Margaret Fox, com idades de 11 e 13 anos, respectivamente, teriam servido de intérpretes dos espíritos causadores de tais manifestações. 
tem forte influência de poder demarcador e delimitador do que seria ou não a sua teoria. Com isso, uma primeira delimitação era posta em jogo e seria a partir dela que seus adeptos, principalmente no Brasil, iriam escorar-se no campo social onde o espiritismo teve lugar.

E pelo visto sua estratégia rendeu frutos. Hoje na França não se reconhece e não se dá outro nome para o movimento espiritualista que não seja o termo “espiritismo"17. A palavra espiritualista no vocabulário cotidiano francês acabou sendo subsumida pelo vocábulo espiritismo. Prova disso encontramos na tradução francesa do livro do inglês Arthur Conan Doyle (1981) - o criador do célebre personagem Sherlock Holmes -, grande espiritualista do século XX. Intitulado originalmente The History of Spiritualism, seu livro na França acabou recebendo o nome de Histoire du Spiritisme. Para maiores esclarecimentos, segue a nota do tradutor:

Diante do problema da equivalência para Modern Spiritualism, preferimos conservar a denominação anlgo-saxônica “espiritualismo moderno" para tudo que seja referente aos países de língua inglesa, permanecendo assim fiel a Conan Doyle. O termo "espiritismo", forjado por Allan Kardec e que reveste por outro lado uma realidade bastante diferente (cf. capítulo XXI), está reservado ao “espiritualismo francofônico". Em compensação, fizemos uma exceção para com o título, por razões de compreensão por parte do público francês pouco familiarizado com o termo "espiritualismo". (DOYLE, 1981, p. 20, grifos nossos, tradução nossa) ${ }^{18}$

17 Apesar de pouco conhecido na França dos nossos dias, o espiritismo, quando citado pelos franceses, na verdade quer dizer todo o movimento maior ligado ao espiritualismo.

18 “Confronté au problème de l'équivalant pour Modern Spiritualism, nous avons choisi de conserver la denomination anglo-saxonne 'spiritualisme moderne' pour tout ce qui concernait les pays de langue anglaise, restant ainsi fidèle à Conan Doyle. Le terme 'spiritisme', forgé par Allan Kardec et qui recouvre d'ailleurs une realité assez différente (cf. chapitre $X X I)$, est reservé au 'spiritualisme francophone'. Nous avons en revanche fait 


\section{A Codificação}

Tido como o primeiro da série de cinco livros considerados "livros da codificação" do espiritismo - Le livre des mediums (1861), L'evangile selon le spiritisme (1864), Le ciel et l'enfer (1865) e La genèse (1868) -, Le livre des esprits está organizado na forma de perguntas e respostas, estilo que carrega a influência pedagógica na qual Kardec fora educado. Além de partir do nó górdio da teoria espírita, a existência de "entidades espirituais”, o livro é a sua base fundamental porque contém o seu próprio delineamento, o seu núcleo central e ao mesmo tempo o arcabouço geral da teoria. Examinando as demais obras da codificação, percebe-se que todas elas partem do seu conteúdo. Assim, n’O livro dos espíritos, os livros I e II, até o quinto capítulo, referem-se ao seu próprio conteúdo. O livro dos médiuns, seqüência d'O livro dos espíritos, trata especialmente da parte experimental da teoria e apresenta um desenvolvimento ampliado e reorganizado (principalmente do nono capítulo intitulado "Intervenção dos espíritos no mundo corpóreo"), tendo sua fonte primária no livro II, a partir do capítulo sexto. O Evangelho segundo o espiritismo é uma decorrência do livro III, em que são estudadas as leis morais, tratando especialmente da aplicação dos princípios da moral cristã, daí a recorrência das "Instruções dos espíritos”, comum e bem particular a este livro, que são transcrições de comunicações e recomendações assinadas por espíritos sobre questões morais presentes nos evangelhos. Decorrente do livro IV "Esperanças e consolações”, O céu e o inferno desenvolve as noções de pena e de gozo terrenos e futuros, e discute os principais dogmas católicos do inferno, do céu, do purgatório e da ressurreição da carne. Todas as partes que tratam dos problemas de ordem cosmológica estão contidas n’A gênese, sendo elas os capítulos II, III e IV do livro I, e capítulos IX, X e XI do livro II.

Esses são, portanto, os "livros da codificação", termo criado e utilizado para se referir especificamente à teoria espírita, já que aqui, como 
postulamos, está em jogo o poder sobre um uso particular de categorias específicas de sinais - fato que possibilita pensar estratégias simbólicas de apresentação e de representação como parte fundamental da análise da conformação do espiritismo.

Além desses livros, há dois outros livros escritos por Allan Kardec: Qu'est-ce que le spiritisme? (1859) e Euvres postumes (1890). O primeiro é um livro introdutório à teoria espírita e é decorrência da "Introdução" e dos "Prolegômenos” d’O livro dos espíritos; já o segundo, representa o testamento doutrinário de Kardec, compondo-se de uma reunião dos seus derradeiros escritos e anotações íntimas.

O que nos chama a atenção no espiritismo, para além de sua construção racional, é a sua natureza complexa no sentido de carregar uma lógica e uma coerência internas, resultado de uma atitude intelectual-teórica. Foi a definição do seu caráter, ao mesmo tempo, científico, filosófico e religioso que causou polêmicas por onde passou. Aqui reside um ponto decisivo da história do espiritismo. Definido enquanto uma nova ciência, o espiritismo questionava a capacidade da ciência que lidava apenas com os aspectos materiais dos objetos e construía limites entre ela e o espiritismo. Mas ao mesmo tempo, Kardec também o definia enquanto filosofia e enquanto religião.

O Espiritismo se apresenta sob três aspectos diferentes: o das manifestações, o dos princípios e da filosofia que delas decorrem, e o da aplicação desses princípios. Daí, três classes, ou, antes, três graus de adeptos: $1^{\circ}$ ) os que crêem nas manifestações e se limitam a constatá-las: para eles [o espiritismo] é uma ciência de experimentação; $2^{\circ}$ ) os que compreendem as conseqüencias morais; $\left.3^{\circ}\right)$ os que praticam ou se esforçam por praticar essa moral. Qualquer que seja o ponto de vista científico ou moral sob o qual encaram esses fenômenos estranhos, cada um deles compreende que é toda uma nova ordem de idéias que surge e cujas conseqüências não podem deixar de ser uma profunda modificação no estado da Humanidade, 
compreendem também que essa modificação não pode verificar-se a não ser no sentido do bem.

Quanto aos adversários, também podemos classificá-los em três categorias: $1^{a}$ ) Os que negam por sistema tudo o que é novo e não procede de suas próprias mentes, e que dele falam sem conhecimento de causa; a esta classe pertencem todos os que não admitem nada fora do testemunho dos sentidos. [...]; para eles o Espiritismo é uma quimera, uma loucura, uma utopia; ele não existe, e eis tudo. Estes são os incrédulos de posição fixada. Ao seu lado podem ser colocados os que não lhe lançaram sequer um golpe de desencargo de consciência, a fim de poderem dizer: Quis ver e nada vi. Eles não compreendem que possa ser necessário mais de meia hora para darem conta de toda uma ciência. $-2^{a}$ ) os que, sabendo muito bem o que devem pensar da realidade dos fatos não obstante os combatem por motivos de interesse pessoal. Para eles, o Espiritismo existe, mas temem suas conseqüências e o atacam como a um inimigo. - $3^{a}$ ) os que encontram na moral espírita uma censura demasiado severa para os seus atos ou as suas tendências. [...] Todos não the opõem senão a negação, nenhum deles apresenta uma demonstração séria e irrefutável em contrário. (KARDEC, 2001a, p. 346)

Assim, nem inteiramente filosofia, nem inteiramente ciência, nem inteiramente religião, o espiritismo não só foi interpretado pelos seus seguidores de diversas formas, como também conseguiu receber ataques de todos os lados, principalmente dos campos científico e religioso.

Entre os cientistas e interessados da época, as opiniões se dividiam quanto aos fenômenos das mesas. Havia aqueles que os consideravam conseqüências da ação de energias humanas, mais precisamente os magnetizadores e seguidores de Mesmer $^{19}$, e havia os que compartilhavam da

${ }^{19}$ Franz Anton Mesmer, médico austríaco que viveu de 1734 a 1815, foi o criador da teoria do "magnetismo animal" conhecida também pelo nome de mesmerismo (notadamente nos séculos XVIII e XIX). Em 1775, após experiências suas, Mesmer acreditou que podia curar mediante a imposição de suas mãos. Pensava que delas desprendia um fluido que 
mesma explicação de Kardec, segundo a qual tais fenômenos seriam o resultado da interferência de “entidades espirituais” dotadas de inteligência e autonomia $^{20}$. É nesse clima de disputas intelectuais que Kardec e alguns amigos lançavam em $1^{\circ}$ de janeiro de 1858 a Revue Spirite, aparelho de produção e de circulação de idéias que viria para defender sua posição na disputa e ao mesmo tempo fazer frente às posições rivais. Laboratório para as idéias que posteriormente seriam consolidadas nas obras $O$ livro dos médiuns, Evangelho segundo o espiritismo, O céu e o inferno e A gênese, a revista, publicada mensalmente, era apresentada como um “journal d'études psycologiques” contendo

O relato das manifestações materiais ou inteligentes dos Espíritos, aparições, evocações, etc., bem como todas as notícias relativas ao Espiritismo. - O ensino dos Espíritos sobre as coisas do mundo visível e do invisível; sobre as ciências, a moral, a imortalidade da alma, a natureza do homem e o seu futuro. - A história do Espiritismo na antiguidade; suas relações com o magnetismo e com o sonambulismo; a explicação das lendas e das crenças populares, da mitologia de todos os povos, etc. ${ }^{21}$

alcançava o doente; praticou durante anos o seu método de tratamento em Viena e em Paris. Concentrado mais precisamente no alívio à dor, Mesmer não desenvolveu a questão da existência do sonambulismo artificial. Coube ao seu discípulo direto, conde Maxime Puységur, o trabalho de relacionar magnetismo e sonambulismo, que seria o "transe magnético" em certas pessoas.

${ }^{20}$ Pouco tempo depois, os espíritas, entre eles o próprio Allan Kardec, traduziriam os conceitos e noções do magnetismo para o linguajar espírita. Assim, "sonâmbulo" tornava-se "médium"; "magnetismo" tornava-se "espiritualismo", "magnetismo animal" tornava-se "passe"; "transe magnético" tornava-se "transe mediúnico". Eram palavras que tinham o som de ciência que o jargão kardecista não logrou alcançar no Brasil, a despeito da pretensão de alguns espíritas de constituir uma ciência empírica, como veremos mais adiante.

21 "Le récit des manifestations matérielles ou intelligentes des Esprits, apparitions, évocations, etc., ainsi que toutes les nouvelles relatives au Spiritisme. - L'enseignement des Esprits sur les choses du monde visible et du monde invisible; sur les sciences, la morale, l'immortalité de l'âme, la nature de l'homme et son avenir. - L'histoire du Spiritisme dans l'antiquité; ses rapports avec le magnétisme et le somnambulisme ; l'explication des légendes 
Em menos de um ano a Revue Spirite passou a ser distribuída em outros países e teve, mais tarde, como colaboradores regulares, entre outros, Victor Hugo e Camille Flammarion. Ela era impressa pela Union Spirite Française et Francophone, organização sem fins lucrativos criada por Allan Kardec e que existe até hoje.

Pode-se, pois, arriscar a dizer que os primeiros anos da formação do espiritismo correspondem a um período qualificado ao mesmo tempo como teórico, com o surgimento do Livre des esprits e da Revue Spirite, e experimental, com Le livre des mediums, publicado em 1861. A essa primeira etapa sucedeu um período de confrontação com o cristianismo e de elaboração das implicações morais e sociais dos ensinamentos dos “espíritos”, resultando na publicação dos livros L'Évangile selon le spiritisme (1864), Le ciel et l'enfer (1865) e La gènese (1868).

A escritora inglesa Anna Blackwell, amiga íntima do casal Allan Kardec e Amélie-Gabrielle Boudet, responsável pela primeira tradução para o inglês tanto d'O livro dos espíritos (em 1869) quanto d’O livro dos médiuns, ressalta no prefácio daquele - onde dedica algumas linhas para falar sobre a biografia do autor - a existência de certas afinidades e disposições religiosas presentes na trajetória de Kardec, disponibilidade que pode ter influenciado e mesmo direcionado a composição de um espiritismo acompanhado de implicações morais, daí entender uma de suas facetas, a religiosa.

Nascido num país católico, mas educado em outro protestante, ele começou, ainda como um simples garoto, a meditar numa maneira de efetuar uma unidade de crenças entre as várias seitas cristãs - um projeto de reforma religiosa no qual ele trabalhou em silêncio por muitos anos, mas necessariamente sem sucesso, não

et croyances populaires, de la mythologie de tous les peuples, etc." Revue Spirite, janeiro de 1858 (tradução nossa). 
tendo à sua disposição, na época, os elementos da solução desejada. (BLACKWELL, [s/d], p. 9, tradução nossa) ${ }^{22}$

Não só na França, mas também nos Estados Unidos e no resto da Europa, as últimas décadas do século XIX foram movimentadas pelos tais "fenômenos" 23 , culminando em uma série de "comissões científicas" que se dividiam entre o reconhecimento da realidade dos fenômenos e sua deslegitimação como fraudes. Ao mesmo tempo subproduto e reação de um cientificismo vulgar, não só essas comissões, mas também os congressos em Paris e a fundação de várias associações espíritas e espiritualistas pela Europa inteira (GIUMBELLI, 1997a, p. 59-60) só fazem sentido quando considerada a existência de um conjunto compartilhado de princípios e de propostas que encerrava o panorama intelectual da época, conjunto este posto em prática pela ação engajada de seus portadores.

\section{O espiritismo no Brasil e suas várias faces}

O espiritismo viajou da Europa para outras nações. O Brasil foi um dos muitos destinos de parada que teve Le livre des esprits, como não podia ser diferente, já que existiam estreitas ligações entre as camadas intelectuais de ambos os países. Pessoas e idéias francesas se faziam sentir em suas influências na academia, nas artes e mesmo na política brasileiras. Entre 1853 e 1854 surgiram no Brasil notícias sobre os fenômenos das “mesas girantes” que ocorriam principalmente nos Estados Unidos e na Europa, publicadas no Jornal do Commércio, do Rio de Janeiro, no Diário de Pernambuco, de Recife, e em

22 "Born in a Catholic country, but educated in a Protestant one, he began, while yet a mere boy, to meditate on the means of bringing about a unity of belief among the various Christian sects - a project of religious reform at which he laboured in silence for many years, but necessarily without success, the elements of the desired solution not being at that time in his possession".

${ }^{23}$ Ver, entre outros, CASTELLAN (1995); DOYLE (1981); WANTUIL (1957). 
O Cearense, de Fortaleza (BARBOSA, 1987, p. 68; WANTUIL, 1957, p. 125127).

Mas em se tratando de uma teoria que se definia ao mesmo tempo religiosa, científica e filosófica, era de se esperar que fosse absorvida e desenvolvida de diversas formas. E foi exatamente o que aconteceu aqui no Brasil. Cada tipo de camada social buscou enfatizar uma das suas possíveis vertentes, ora pendendo mais ao cientificismo, ora à face religiosa, ora às idéias puramente filosóficas. Se hoje conhecemos o espiritismo como uma religião minimamente sistematizada entre diversas outras em oferta no mercado religioso brasileiro, é porque por detrás de todo esse processo de sua introdução e legitimação no Brasil, um grupo frente aos demais conseguiu vencer a disputa e alcançar assim a posição estatutária de ditar o que seria (ou não) espiritismo.

A colônia de imigrantes franceses no Rio de Janeiro, então capital do Império, composta por jornalistas, comerciantes e professores, teve papel importante para a entrada do espiritismo em terras brasileiras. Tendo seus primeiros adeptos nesse meio de franceses, o espiritismo dava os seus primeiros passos com a publicação do livro Les temps sont arrivés, escrito em francês pelo professor Casimir Lietaud em 1860, diretor do Colégio Francês, estabelecimento de ensino dos mais conceituados da Corte. Casimir e os demais imigrantes, principalmente Adolpho Hubert e Madame Collard, agrupavam-se no Courrier du Brésil cuja redação tinha uma linha claramente anticlerical e contrária ao governo de Napoleão III. Foi nessa roda que a teoria espírita encontrou grande receptividade. Mas ao contrário do que hoje entendemos como espiritismo, naquele instante ele não surgia somente como uma nova opção religiosa. Ele estava ali entrelaçado com as modernas tendências políticas e filosóficas, em particular com o socialismo ${ }^{24}$. A

${ }^{24} \mathrm{Na}$ França, após a morte de Kardec, quem passou a se destacar foi Léon Denis (1846-1927), socialista e maçom, espírita que imprimiu ao movimento uma direção mais acentuadamente anti-católica, principalmente a partir de 1880 . É dele o livro intitulado Socialismo e espiritismo. 
explicação das desigualdades sociais era também relacionada às diversas existências da alma, às reencarnações, e nesse grupo mesclavam-se às leituras de Kardec as leituras de Saint-Simon, Charles Fourier e Pierre Leroux ${ }^{25}$. Graças a esse entrelaçamento entre o espiritismo e as idéias socialistas, o Courrier du Brésil se tornou o primeiro ninho onde se agasalharam as crenças espíritas. Mas apesar de ser um grupo de pessoas de prestígio econômico, social e cultural, a colônia francesa carioca restringiu suas relações com o espiritismo em algumas reuniões e algumas poucas publicações, limitando sua circulação e sua receptividade naquele momento. Além disso, era um tanto quanto inusitado para a sociedade da época a discussão sobre socialismo e reencarnação. O socialismo não tinha grande repercussão no debate políticoideológico do Brasil do século XIX, mais compromissado com questões políticas e jurídicas - como o republicanismo e o abolicionismo - do que com uma revolução social. E como, nesses precisos termos, não se mostrava como opção religiosa, a Igreja no Rio de Janeiro não fez grandes oposições ao espiritismo ao longo da década de 1860.

É interessante observar aqui que as afinidades entre espiritismo e socialismo, ou mesmo entre espiritismo e feminismo ${ }^{26}$, são combinações de tradições culturais bastante específicas da França, o que não ocorreu no Brasil

${ }^{25}$ Pierre Leroux (1797-1871) em sua principal obra, De l'humanité, de son príncipe et son avis, où se trouve exposée la vrai définition de la religion (1840), defende os princípios de um socialismo religioso, calcado na solidariedade humana.

${ }^{26}$ Já desde as conferências pronunciadas na série de viagens realizadas pela França em prol da expansão das idéias espíritas (conferências publicadas no livro Voyage de 1862, que na edição brasileira recebeu o nome de Viagem Espírita em 1862), Kardec declarava que a igualdade de direitos entre homens e mulheres deveria ser reconhecida em todas as partes e que o espiritismo, nesse sentido, teria papel importante na propagação desse ideal. É por isso que em 1896, na Revue Spirite, aparece a proposta do sufrágio ser estendido às mulheres. Todas essas idéias fazem parte de uma marca universalista presente no pensamento de Kardec que vinha desde a sua mocidade. Segundo Marion Aubrée e François Laplantine (1990), a dimensão do feminismo no espiritismo seguia uma corrente mais geral. Por isso que Flauvety, na Revue Spirite de maio de 1882, afirmava que a igualdade dos direitos é "uma conquista por fazer, iniciada pelo movimento saint-simonien". 
da mesma época. A resposta a essa diferença certamente não está nos trabalhos que tomam o espiritismo como uma totalidade, independentemente de seus atores. Abandonando esta perspectiva, torna-se mais fácil compreender porque o espiritismo no Brasil teve forma, direção e sentido diferentes segundo os repertórios contextuais aqui disponíveis. Entretanto, para que uma equivalência possa dar lugar a um tipo determinado de integração ou de interação, não basta que os elementos culturais estejam simplesmente disponíveis; é preciso ainda que ela seja anunciada por alguns agentes e também reconhecida e significada como tal pelos grupos interessados.

Apesar de não progredir na Corte, o espiritismo, através dos franceses e de suas relações sociais, rondou a elite da sociedade imperial. Em conversas, ainda que tímidas, nas ruas ou em pequenas sessões espíritas, a nova teoria foi angariando os seus primeiros adeptos brasileiros. Pessoas de influência social e que por isso não sofriam qualquer tipo de repressão.

Seria, entretanto, em outra província que o espiritismo ganharia maior exposição pública. Oficialmente, a eclosão do espiritismo brasileiro se daria no ano de 1865 em Salvador, com a fundação da primeira agremiação espírita, o Grupo Familiar do Espiritismo. Luís Olímpio Telles de Menezes, seu fundador, mantinha contatos com Casimir Lietaud no Rio de Janeiro e com vários espíritas da França. A partir de seus esforços, a posição do espiritismo se inverteu: a Bahia passou a ser a capital do espiritismo e o Rio de Janeiro, uma de suas províncias (MACHADO, 1983).

Telles de Menezes foi criado em uma família católica, como era de se esperar, já que o catolicismo era a religião oficial do Império e a que detinha o monopólio religioso. Filho de militar, após desistir da mesma carreira do pai por falta de aptidão, segue outras escolhas profissionais que o sistema provinciano lhe permitia. Foi então que acabou se dedicando ao magistério e ao jornalismo. Enquanto educador, participou da campanha contra o analfabetismo e ao incentivo da literatura entre os jovens baianos num Brasil cujo ensino das primeiras letras tinha sido recém decretado (1827). Por vários anos, Telles de 
Menezes foi professor de instrução primária e de latim. Apreciador do purismo gramatical, publicou um compêndio a que deu o título de Ortoépia da língua portuguesa. Foi convivendo, portanto, nos meios mais letrados e cultos que Telles de Menezes estabeleceu relações com reconhecidos educadores baianos, tendo diversos deles, mais tarde, colaborado na propaganda do espiritismo.

Paralelamente a isso, Telles de Menezes também se dedicou, e muito, ao jornalismo e às letras. Escreveu em vários jornais e revistas da imprensa leiga de Salvador, dentre eles no Diário da Bahia, no Jornal da Bahia e no Interesse Público, períodos considerados àquela época os mais importantes da província baiana. E ainda como jornalista, em 1849, ingressou como redator do periódico A Época Literária, tendo mais tarde passado a ser seu diretor. Nele, publicou, mesmo sem muita experiência e antes de se tornar espírita, a novela Os dois rivais, em formato de folhetim e num estilo ultra-romântico, uma das primeiras manifestações de ficção na Bahia (Cf. SALLES, 1979). Publicada sobre os auspícios do poeta e estadista Domingos Borges de Barros, o Visconde de Pedra Branca, A Época Literária saía mensalmente pela Tipografia de Carlos Poggetti e, pouco depois, pela Tipografia de Epifânio José Pedrosa. Era, então, uma das poucas folhas literárias existentes na Bahia. Telles de Menezes contava nessa época 24 anos de idade e possuía projeção quase nula nos meios literário e artístico. Por conta disso seu nome não constou no frontispício da revista, uma vez que somente os nomes conhecidos e reconhecidos facilitariam a sua divulgação, embora tenha escrito o artigo de fundo - o editorial - do primeiro número, sob as iniciais L.O.T.M. Continuou escrevendo no periódico algumas outras vezes, entre elas, assinando outro editorial, meses depois, com o mesmo título do primeiro: "Lede".

Se os nossos esforços, empregados no primeiro período, satisfizeram ao público sensato e justo avaliador, preenchendo os deveres da árdua tarefa que nos impusermos, é o que não podemos afirmar.

Que não nos poupamos a dificuldade alguma, para com pontualidade desempenharmos o que prometemos, - embora não 
pudéssemos inteiramente tornar o nosso periódico tão interessante como desejávamos, é o que podemos assegurar aos nossos leitores.

Se o público consciencioso continuar a acolhê-lo com aquela benignidade, com que o há feito, desculpando generosamente a nós, que inda agora estreamos a carreira das letras, então o nosso periódico, escudado - como se acha - por uma das notabilidades literárias da Bahia, irá, assim mesmo despido de todas as galas, modestamente sentar-se no meio das publicações deste gênero, que atualmente se fazem nos diversos pontos do Império Brasileiro.

Infelizmente na Bahia - e com profunda mágoa o dizemos! -, ainda um pouco atrasada em civilização (bem entendida), não podem tais empresas encontrar um pleno apoio, tão necessário para a sua animação, desenvolvimento e bom êxito.

E ordinariamente eis o que sucede:

Aqui, levantam-se cabeças orgulhosas de sua posição social, que com requintado desdém olham para a nova publicação.

E por que assim o fazem?

Porque ocupadas no cultivo da política, deslumbradas pelo futuro que elas lhes promete, anteolha-se-lhes árido e estéril o campo das letras, tanto mais quanto se julgam homens da primeira plana, e este autor não freqüenta a roda a que tanto se ufanam eles de pertencer.

Ali, surgem outras, que, sem ao menos lerem a obra ou o jornal, previamente o condenam, porque - dizem - não gostam de ler escritos de autor desconhecido, que não tem fama, por isso que estão acostumados a aplaudir as obras, quaisquer que sejam, não pelo seu mérito, mas sim pela nomeada do indivíduo.

Além, aparecem antagonistas que, ciosos (talvez) de não serem os pais da idéia novamente emitida, buscam com terrível egoísmo cavar a ruína da nascente empresa.

- Que devemos pensar de tudo isso? 
- É questão a que nos forramos de responder, porque nela existe o cunho da ignorância e do amor-próprio mais degenerado.

É portanto com todos estes obstáculos que o nosso periódico - que nos aprouve chamá-lo “A Época Literária” - tem lutado, e há-de relutar no ir por diante de sua existência; mas desprezando nós tudo quanto com seus envesgados olhos puder tramar a desprezível inveja, e confiando na benevolência do público sensato e justo, - diremos ainda uma vez, cheios de entusiasmo, com o Poeta brasileiro:

...Senhor, propício atende:

Nada por nós, por nossa Pátria tudo;

Fados brilhantes ao Brasil concede.

Bahia, 25 de março de 1850. (L.O.T.M.) ${ }^{27}$

Apesar de maciços esforços, apresentados e talhados nesse editorial, Telles viu sua empreitada não render muitos frutos, mesmo com a entrada na redação, em 1851, de três importantes personalidades da sociedade baiana, Dr. Manoel Maria do Amaral Sobrinho, José Álvares do Amaral e Dr. Inácio José da Cunha (o primeiro pertencente à conhecida família de políticos baianos; os outros dois tornaram-se, juntamente com Telles de Menezes, pioneiros do movimento espírita no Brasil). Neste mesmo ano, em outro editorial, Telles solicitava a ajuda dos assinantes, mas acabou sofrendo finalmente o golpe de ver A Época Literária, depois de pouco tempo, sair de circulação. Entretanto, as suas investidas, ou melhor, os seus esforços despendidos no sentido de construir sua posição no domínio das artes não pararam por aí.

Em 1857, o literato e dramaturgo Dr. Agrário de Souza Menezes fundava em Salvador o Conservatório Dramático da Bahia cujo corpo de sócios havia sido limitado àqueles que "tivessem dado provas de inteligência

${ }^{27}$ Disponível em: < www.telma.org.br>. Acesso em: 15 nov. 2007. 
cultivada e de gosto pela arte dramática”28. Telles de Menezes não tardou em fazer parte desse conservatório, do qual participaram também destacadas personalidades baianas como: Rui Barbosa, Castro Alves, Frei Carneiro da Cunha, Júlio César Leal, Filgueiras Sobrinho, Amaral Tavares, Pinto Paca, Álvares da Silva, Belarmino Barreto, Guedes Cabral, Cunha Vale, Rodrigues da Costa e Paulino Gil. Assim, inserido no círculo das artes, já era de se esperar que os fatos ocorridos na França chegassem até o conhecimento de Telles de Menezes, posto que o intercâmbio de idéias através da correspondência epistolar mantida entre os dois países facilitou a chegada a terras baianas das tendências filosóficas e culturais que emergiam no além-mar, tendências que acabaram estimulando vivamente os interesses de Telles. Numa dessas cartas, Telles de Menezes chegou mesmo a se corresponder com o professor Rivail, e durante a implantação do espiritismo na França, manteve relações de amizade com os espíritas franceses. Foram, portanto, os seus contatos pessoais, propiciados pela sua situação social, uma das vertentes responsáveis pela entrada do espiritismo no Brasil.

Empolgado e empenhado com as novas idéias, Telles de Menezes publicaria tempos depois na capital baiana o opúsculo $O$ espiritismo introdução ao estudo da doutrina espírita (1865), contendo páginas traduzidas por ele da $13^{\mathrm{a}}$ edição do Le livre des esprits, a tradução de um apêndice de outro autor francês, e um prefácio intitulado "Lede”, em que Teles de Menezes diz sobre seu júbilo "de ter sido o primeiro na Bahia que, fervorosamente, esposou a doutrina espírita” 29.

Dessa forma, ao traduzir parte do livro de Allan Kardec, Telles de Menezes abria a um público maior o acesso à nova forma de visão de mundo, levando o espiritismo para além das rodas intelectuais. Seu trabalho de difusão das idéias espíritas se desenvolveu através do mecanismo que ele mais dominava: a imprensa - como veremos mais adiante.

\footnotetext{
${ }^{28}$ IDEM.

${ }^{29}$ IDEM.
} 
Foi assim que Telles de Menezes começava, sob a bandeira do espiritismo, a reunir em torno de si personalidades cujo capital social era bastante ampliado, entrando, dessa maneira - e não mais através das artes - no grupo dos aristocratas como Antônio da Rocha Pitta e Argollo, Visconde de Passé, considerado o homem mais rico do Brasil, e o Barão de Sauípe; médicos como o Dr. Joaquim Carneiro de Campos, filho do Marquês de Caravelas, e o Dr. Guilherme Pereira Rebelo; e até o ex-presidente da Província, Álvaro Tibério de Moncorvo e Lima, comendador da Ordem da Rosa. Com tamanho respaldo de homens importantes da economia e da política baianas, Telles de Menezes começava sua empreitada com grande peso legitimador decorrente dessas relações, muito embora ele mesmo não proviesse dessa camada social e economicamente mais privilegiada. E foi utilizando-se delas que Telles soube emplacar o espiritismo no Brasil.

A rapidez de sua propagação [do espiritismo] prova, exuberantemente, que se trata de uma grande verdade, que, necessariamente, há de triunfar de todas as oposições e de todos os sarcasmos humanos; e isso não é difícil de demonstrar-se, se atendermos que o Espiritismo faz seus adeptos, principalmente, na classe esclarecida da sociedade. (WANTUIL, 2002, p. 579) ${ }^{30}$

Envolvido agora na propagação do espiritismo, aos 8 de março 1869, Telles de Menezes reuniria seus companheiros no Grêmio de Estudos Espiríticos da Bahia para anunciar a fundação do primeiro jornal espírita do Brasil, O Echo d'Além-Túmulo, com o subtítulo de Monitor do espiritismo no Brasil. O jornal bimestral circulou não só na Bahia, mas em outras partes do território nacional, bem como em Paris e em algumas outras capitais européias. Imprimiu-o a Tipografia do Diário da Bahia.

\footnotetext{
${ }^{30}$ Com o propósito de manter uma maior clareza, optamos em modificar a grafia das citações das publicações do final do século XIX e início do século $X X$, que serão muito freqüentes neste trabalho, para a grafia do nosso uso hodierno.
} 


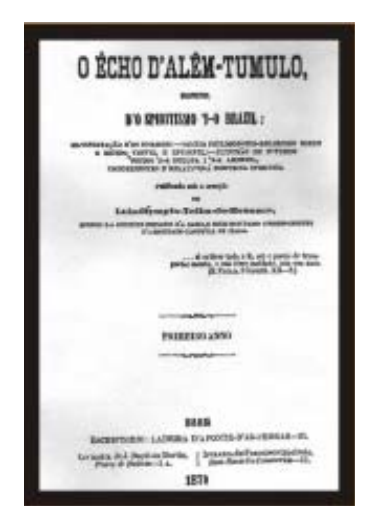

Echo d’Além Túmulo Capa

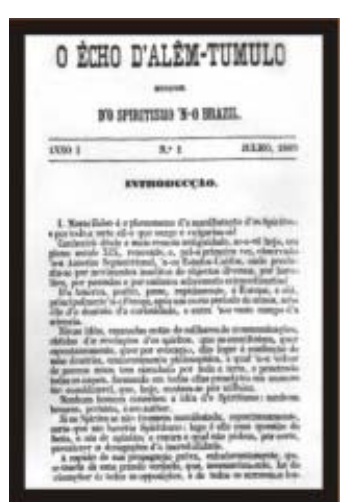

Echo d'Além Túmulo Primeira página

Eis um trecho do discurso proferido por Luís Olímpio Telles de Menezes na ocasião, publicado no jornal em questão, em setembro de 1869:

Meus respeitáveis Irmãos Espíritas,

A idéia espirítica no curto espaço de três anos e meio, que há decorrido de sua manifestação entre nós, tem-se difundido com rapidez verdadeiramente providencial, não sem obstáculos, antes, sim, com sacrifício da parte daqueles que esposaram essa idéia de regeneração social. Contudo, disseminada e ainda sem corpo, longe está ela de poder, desde já, converter-se na crença que mais tarde, com o favor de Deus, há de imprimir impulso e direção ao elemento de civilização e de perfectibilidade da sociedade humana, porque tudo nos diz que ela é o único móvel que poderá levar a efeito esse desideratum de todo coração generoso que, sinceramente, palpita com os sentimentos da verdadeira caridade.

A nós que nos achamos hoje reunidos, constituindo, naturalmente, o Grêmio dos Estudos Espiríticos na Bahia, e a quem certa vocação do Alto cometeu o empenho desta árdua missão, árdua e até espinhosa, sim, mas irradiante de bem fundadas esperanças, incumbe, pelos meios que de mister é serem empregados, propagar essa crença regeneradora e cristã, fazendo-a chegar, indistintamente, a todos os homens; e o meio material que a Providência sabiamente nos oferece para levar, rapidamente, a palavra da verdade à inteligência e ao coração de todos os homens, é a - Imprensa. 
De há muito era por todos nós sentida a necessidade de possuir-se uma publicação regular para consecução desse fim, preenchendo todas as condições necessárias à propagação da salutar crença espirítica. Os elementos estavam lançados, e esta é a ocasião mais azada de invocar o vosso concurso e o vosso apoio para a execução e próspero resultado deste empenho ${ }^{31}$.

Analisando as suas ligações, os seus conhecimentos e os seus investimentos, pode-se começar a entender como Telles de Menezes conseguiu ir razoavelmente longe com o espiritismo nascente no Brasil. Ao serem reveladas as suas relações sociais com os aristocratas baianos e com os espíritas franceses, e toda a sua trajetória relacionada à educação, ao jornalismo e às letras, podemos, assim, descobrir e entender o fulcro responsável pelo surgimento de seus contatos primordiais com o espiritismo e, conseqüentemente, responsável pela sua entrada em terras brasileiras. É assim que se explicam os caminhos pelos quais Telles de Menezes pôde traçar segundo as alternativas que lhe estavam disponíveis; alternativas estas que lhe permitiram adquirir os necessários conhecimentos dos mecanismos de funcionamento da imprensa que, por sua vez, possibilitaram-no não só fundar um jornal, como também angariar fundos econômicos e respaldo organizacional.

Assim, mesmo já trabalhando há algum tempo em prol do espiritismo, foi somente com o surgimento do periódico que o seu reconhecimento começou a nascer. Foi sem dúvida uma estratégia certeira que conseguiu rapidamente visibilidade, não tardando os elogios vindos inclusive da França. A Sociedade Anônima do Espiritismo, da qual fazia parte l'Union Spirite Française et Francophone de Paris, que então dirigia a Revue Spirite, agradeceu epistolarmente a Telles de Menezes, por seu secretário geral A. Desliens, a remessa do primeiro número d'O Echo d'Além-Túmulo, enaltecendo o trabalho dos espíritas do outro lado do Atlântico e elogiando sobremaneira o novo órgão

${ }^{31}$ Echo d'Além-Túmulo, setembro de 1869 (grifos do autor). 
de difusão do espiritismo. O aparecimento do Echo d'Além-Túmulo foi então registrado na seção "Bibliographie" da Revue Spirite de outubro de 1869, e em novembro do mesmo ano, uma extensa apreciação, ocupando quatro páginas, foi feita a seu respeito, com a citação de longo artigo extraído dele e vertido para o francês.

Mas apesar do empenho de Telles de Menezes e da apreciação de seu trabalho pelos espíritas franceses, O Echo d'Além-Túmulo teve inúmeras dificuldades e por isso sua duração não foi muito longa. Daí ter percorrido o seu primeiro ano relativamente bem, mas pôde apenas encetar o segundo, mesmo tendo sido um órgão importante na difusão dos primeiros passos do espiritismo no Brasil ${ }^{32}$. Pois foi a partir desse exemplo que muitos começaram a conhecer o espiritismo, e muitos outros periódicos puderam vir à luz.

Entretanto, a maior reação provocada pelo trabalho de Telles de Menezes não veio de Paris; veio sim do clero brasileiro. Uma Pastoral lançada em 16 de junho de 1867 pelo arcebispo da Bahia D. Manuel Joaquim da Silveira foi a réplica mais imediata da Igreja Católica frente à dilatação do espiritismo. Por irônico que seja, coube exatamente à Igreja o gesto de entreabrir as portas ao espiritismo para adentrar o campo religioso brasileiro.

${ }^{32}$ Foi em um dos números d'O Echo d'Além Túmulo que Telles de Menezes registrou o exemplar que o funcionário da Fazenda, Júlio César Leal, oferecera-Ihe de seu livro $O$ espiritismo - Meditações poéticas sobre o mundo invisível, acompanhadas de uma evocação, editado na cidade de Penedo (Alagoas), com prefácio de 18 de novembro de 1869. Fora ela a primeira obra poética de fundo espírita publicada no Brasil. Esse baiano, dramaturgo, jornalista, poeta e romancista, haveria de ser eleito, em 1895, presidente da Federação Espírita Brasileira. E não foram somente Telles de Menezes e Júlio César Leal os únicos literatos a se envolverem com o espiritismo. Mais tarde, Bittencourt Sampaio também viria a ser espírita, e de uma forma bastante marcante para o desenvolvimento do espiritismo no Brasil. 


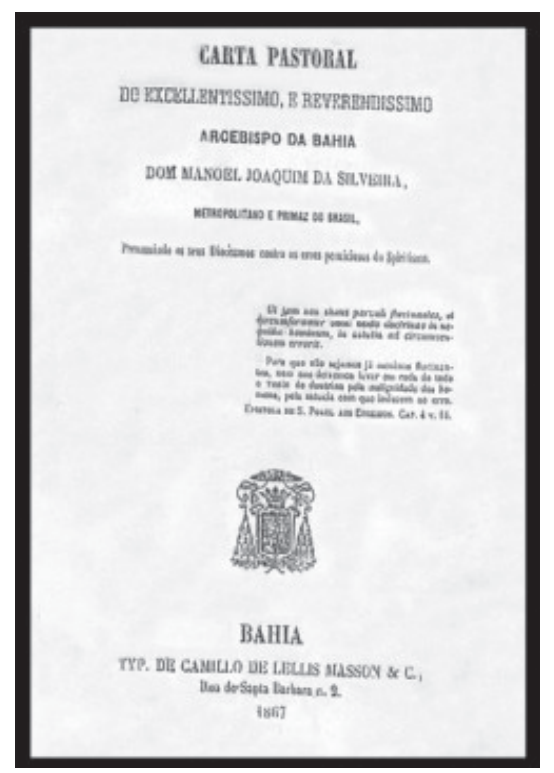

Carta Pastoral do Arcebispo da Bahia Dom Manuel Joaquim da Silveira (1867)

Filosófico, científico e religioso desde o seu começo, o espiritismo ainda não tinha se definido essencialmente como religião no Brasil até aquele momento, muito embora contivesse em si a possibilidade de vir a sê-lo, já que uma de suas definições é a religiosa. Mesmo com os trabalhos de Telles de Menezes, ninguém se dizia espírita como afirmação de uma opção religiosa em detrimento do catolicismo.

Reconhecendo a expansão do espiritismo em terras brasileiras, a Pastoral dialogou principalmente com a tradução de trechos da obra de Allan Kardec feita por Telles de Menezes nos seguintes termos:

Nessa capital publicou-se um pequeno livro com o título Filosofia Espiritualista - o Espiritismo - cujas perniciosas doutrinas, contra toda expectação, têm tomado incremento, pondo-se em prática certas superstições perigosas e reprovadas, que estão no domínio do público, e no interesse da vossa salvação, amados Filhos. Nós julgamos conveniente dirigir-vos esta Carta Pastoral, para prevenirvos contra os principais erros que contém esse pequeno livro, e contra as superstições, que segundo as doutrinas nele contidas se estão 
praticando, como se Nos tem informado, e do que já não é possível duvidar ${ }^{33}$.

Assim, para impedir a disseminação das idéias de Kardec, nada melhor do que expor contrariamente a elas os dogmas da Igreja, linguagem específica de um diálogo religioso. No entanto, é necessário aclarar que nesse primeiro confronto não houve a intenção, em nenhum momento, por parte dos espíritas de negar a sua religião católica e contra ela investir pesados esforços - atitude bem comum por parte dos espíritas da época e de muitos espíritas da atualidade. E essa é justamente umas das características que até hoje encontramos no campo da religiosidade brasileira. Feito uma característica desse campo que perdura no tempo desde sua gênese, a atitude de certos espíritas contemporâneos de se assumirem também católicos talvez venha como uma possibilidade explicativa - dos nossos primeiros espíritas, de seus primeiros trabalhos que defendiam o espiritismo como sendo apenas uma correção necessária aos dogmas católicos e não como uma religião sistematizada. E se não foi dessa maneira, foi de outra, posto que anos mais tarde alguns dos principais espíritas iriam conjugar o espiritismo - agora tido como religião - com alguns dos dogmas católicos (assunto tratado mais adiante). Aliás, Telles de Menezes reivindicava até com certa insistência a sua condição de católico “de nascimento e de crença” ${ }^{34}$, e ainda voltou a insistir ao afirmar que “o Espiritismo e o Catolicismo são a mesma Igreja de NOSSO SENHOR JESUS CRISTO: somente estão mudados os tempos e as palavras: o Espiritismo é o tradutor fiel, pelos enviados de Deus, das doutrinas do Evangelho" 35 .

${ }^{33}$ SILVEIRA, D. Manuel Joaquim da. Pastoral da Diocese da Bahia. In: MACHADO (1983, p. 84).

34 MENEZES, Luís O. T. de. O Espiritismo. Carta ao Excelentíssimo e Reverendíssimo Senhor Arcebispo da Bahia, D. Manuel Joaquim da Silveira. In: MACHADO (1983, p. 89).

${ }^{35}$ IDEM. 
Ocorria que para Telles de Menezes a Igreja não estava conseguindo acompanhar as mudanças trazidas pelos novos tempos, perdendo assim o seu papel de “autoridade máxima da palavra de Deus”. Daí a sua tão necessária reformulação, compatível com o novo momento histórico, vinda através das modificações propostas pelo espiritismo. Mas isso não mudaria a sua base fundamental, que continuaria sendo os livros bíblicos, principalmente o Novo Testamento, só que agora recuperado e adaptado às novas interpretações, e sob uma nova linguagem.

É interessante destacar que o prefácio da $2^{\mathrm{a}}$ edição do livro de Telles traz como terceira epígrafe - retirada do livro de Roselly Lourgues, Jesus Cristo perante o século - a afirmação de que o dogma de Jesus Cristo em si “conserva-se em uma sublime imutabilidade, os métodos porém de sua exposição devem acompanhar o espírito humano em seu desenvolvimento e o tempo, em sua progressão" (FERNANDES, Magali de Oliveira, 1993, p. 68).

Era ainda a sua vontade de fazer do espiritismo um meio revelador de novas versões dos ensinamentos cristãos, uma espécie de renovação, um revigoramento, uma modernização mesmo do catolicismo. Mas não só do catolicismo; o espiritismo aparecia também como uma nova teoria social, mais moderna, capaz de explicar de forma inédita muitas das injunções sociais.

Mas seguramente toda essa onda reformista não evitou as disputas simbólicas. Aliás, já era de se esperar que as novas idéias não fossem pronta e pacificamente aceitas, uma vez que trazem consigo a heterodoxia, isto é, contestavam algumas das verdades indiscutíveis tradicionalmente propagadas e defendidas pela Igreja. Assim, as disputas certamente existiram; e mais, vieram no campo da ordem dogmática. O ponto mais explosivo, porque pretendia inovar as próprias crenças católicas, era sem dúvida a reencarnação, que está entrelaçada na doutrina de Kardec à idéia de justiça divina. Entretanto, um outro ponto inquietava ainda mais a igreja católica, pelo menos o arcebispo D. Manuel: a manifestação dos espíritos. A invocação dos mortos, que já era praticada pelos negros, entendida como pura superstição e tolerada pela igreja - 
que a via como válvula de escape para aliviar a tensão da vida no cativeiro ameaçava invadir a "casa grande”. No entanto, por outro lado, no que tange à noção de Juízo Final, crença que contradiz a concepção de reencarnação, Telles de Menezes em nada se opunha, fato que demonstrava desajustes no seu pensamento e no de seus seguidores. Acreditar na ressurreição dos mortos no fim dos tempos e ao mesmo tempo na reencarnação está longe de mostrar um trabalho de racionalização que segue o imperativo da coerência. É por isso também que os adeptos do espiritismo nesse momento ainda não o enxergavam enquanto religião, enquanto uma visão de mundo sistematizada, doadora de sentido à vida, organizada e mantida através de instituições.

Curioso aqui é notar que uma outra característica, uma outra invariável pertencente ao campo religioso brasileiro talvez tenha partido desse processo acima descrito. Segundo uma enquete ${ }^{36}$, mais da metade dos católicos hoje acredita na reencarnação, o que nos faz crer que bem ou mal o trabalho de introdução das idéias espíritas teve resultados a partir de então. Pois, se Telles de Menezes não logrou reformar a Igreja como almejava, pelo menos foi o mentor da inculcação do dogma da reencarnação em parte dos católicos brasileiros. Isso equivale a dizer que, embora o trabalho de Telles de Menezes naquela circunstância não tenha formatado o espiritismo enquanto uma religião, teve pelo menos, sob aquela configuração específica, papel importante na formação do campo da religiosidade brasileira.

\section{O entreabrir das portas}

A dimensão social que o espiritismo começava a tomar por ter atingido setores para além das camadas mais privilegiadas da sociedade baiana, por conta justamente das traduções de Telles de Menezes e da criação do seu periódico, também causava preocupações reconhecidas naquela Pastoral:

${ }^{36}$ Essa enquete foi realizada no final de 2001 pelo instituto Vox Populi a pedido da revista Veja, e constatou que $59 \%$ da população brasileira acredita que já teve outras vidas, apesar de somente $3 \%$ se declarar espíritas. 
Os efeitos mais claros do Espiritismo são, na ordem religiosa, a negação cada vez mais geral do Cristianismo como obra divina, e como religião positiva: o enfraquecimento do temor dos juízos de Deus; a confiança na metempsicose, que transportando ao décimo-nono século os erros do gnosticismo teórico, conduz ao gnosticismo prático, isto é, à emancipação de todas as inclinações corrompidas (FERNANDES, Magali de Oliveira, 1993, p. 85).

Foi por isso que o folheto $O$ Espiritismo. Carta ao Excelentíssimo $e$ Reverendíssimo Senhor Arcebispo da Bahia, D. Manuel Joaquim da Silveira não tardou a ser produzido por Telles de Menezes. Escrito no mesmo ano da Pastoral, foi a primeira formulação brasileira sobre as teorias espíritas, contando 82 páginas. Juntamente com esse folheto, Telles de Menezes também investiu esforços ao escrever o prefácio de 25 páginas da 2a edição de seu livro. Ambas as produções tiveram estratégias diferenciadas da primeira edição, composta apenas pelos trechos traduzidos d'O livro dos espíritos. Agora o que já se vê são escritos com tons mais discursivos, muito parecidos com os usados na Pastoral, a começar com um texto repleto de citações e notas. Eram, pois, obras mais densas e menos emocionais. Foram ao todo mais de 120 páginas para provar que o espiritismo não tinha nada a ver com o que dissera o Arcebispo da Bahia, isto é, com magia, práticas supersticiosas, fábulas ou contos maravilhosos.

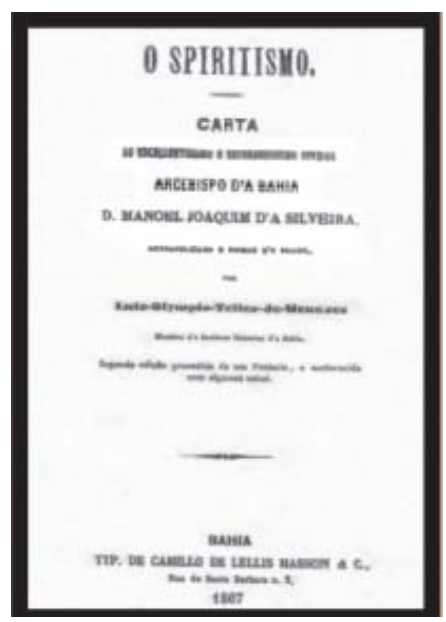

Carta de Telles de Menezes ao Arcebispo da Bahia (1867) 
Seguindo a mesma técnica de convencimento da Pastoral, Telles de Menezes começava a ter agora adversário definido e regras a seguir. Respondeu item por item enunciados pelo Arcebispo como "práticas perniciosas”. Entre eles estavam obviamente os três principais pontos de divergência entre o catolicismo e o espiritismo: a preexistência da alma, a sua transmigração e a evocação dos mortos.

Uma vez com esses escritos espíritas primordiais em mãos, torna-se mais fácil examinarmos e compreendermos de que maneira o espiritismo foi inicialmente visto e entendido no Brasil por pelo menos parte de seus primeiros adeptos. Através da análise desses parágrafos podemos verificar a forma pela qual o conteúdo da teoria espírita foi absorvido e desenvolvido, além de identificar quem foram os seus interlocutores, seguidores ou opositores.

Dessa maneira, o espiritismo nesse momento viera somente para “atualizar” e "preencher” lacunas da Igreja ao propor a aceitação do dogma da reencarnação, que tudo explicaria e tudo justificaria, sobretudo as diferenças sociais; ele viria assim “rearranjar” o sistema de crenças católico, dando-lhe mais coerência e maior plausibilidade. Telles de Menezes apostava realmente na crença da reencarnação, já que

[...] esse modo de encarar a vida resulta a diminuição da importância das coisas deste mundo, e leva o homem a moderar seus desejos e a contentar-se com a sua posição, sem invejar a dos outros; atenua a impressão moral dos revezes e descontentamentos, que experimenta, haurindo daí calma e resignação assaz úteis tanto à saúde do corpo, como à inquietação da alma e à paz do espírito [...].

Deus é justo, e não deixou coisa alguma ao acaso, nem à fatalidade. Tudo quanto acontece no mundo, ainda que possamos dar a razão de muitas coisas, nem por isso devemos deixar de atribuir à justiça divina: - e não será esta a idéia de muito mais moral, muito mais consoladora e muito mais verdadeira? (IDEM) 
Assim, certas prerrogativas espíritas convinham a Telles de Menezes à medida que lhe proporcionavam respostas imediatas aos problemas morais, o que não as impedia, por outro lado, de desempenharem também funções sociais de justificação para além daquelas referentes às angustias e/ou aflições da vida. Telles formulava dessa maneira artifícios para que o homem se contentasse, ou até mesmo se resignasse, com a sua posição social. Paradigmático é o seu próprio caso, pois por mais estudioso e bem relacionado que ele tenha sido, Telles de Menezes se situava em um espaço social que não era nem aristocrata, nem social e economicamente desprivilegiado. Noutras palavras, muito embora participasse do círculo de grandes homens baianos, Telles de Menezes ainda assim não provinha desse meio social, e o espiritismo o auxiliava a se conformar, a não questionar a sua posição. Ele parece negar a possibilidade de existir uma sociedade do acaso e do absurdo. O que tentava fazer no seu discurso espírita era, portanto, uma espécie de reorganização, ou melhor, uma tradução da realidade social à luz do espiritismo, realidade esta que naquele momento vivia um processo intenso de transfiguração. Não só a cidade de Salvador, mas o Brasil enfrentava grandes mudanças: o movimento abolicionista, que culminou com o fim da escravidão em 1888, ocasionando uma crise na mão-de-obra da lavoura; a Guerra do Paraguai (1870), que resultou na politização do exército e no fortalecimento das idéias republicanas; os conflitos entre a Igreja e o Império Brasileiro ${ }^{37}$; as reivindicações cada vez maiores de uma camada social média (da qual pertenciam funcionários

${ }^{37}$ A "questão religiosa", denominada nesses termos, refere-se ao conflito entre igreja católica e Império Brasileiro. Desde o período colonial, a Igreja era uma instituição submetida ao Estado. Isso significava, entre outras coisas, que nenhuma ordem do Papa poderia vigorar no Brasil sem que fosse aprovada pelo imperador, ao que se deu o nome de Regime de Padroado. Ocorre que, em 1872, Dom Vital e Dom Macedo, bispos de Olinda e Belém respectivamente, resolveram seguir as ordens do Papa Pio IX (não ratificadas pelo imperador), punindo religiosos ligados à maçonaria. D. Pedro II, influenciado pelos maçons, decidiu intervir na questão, solicitando aos bispos que suspendessem as punições. Estes se recusaram a obedecer ao imperador, sendo condenados a quatro anos de prisão. Em 1875, graças à intervenção do Duque de Caxias, os bispos receberam o perdão imperial e foram colocados em liberdade. Contudo, o Império foi perdendo a simpatia da Igreja e vice-versa. 
públicos, profissionais liberais, estudantes, artistas, comerciantes) que estava crescendo nos grandes centros urbanos e desejava mais liberdade e maior participação nos assuntos políticos do país, identificando-se, assim, com os ideais republicanos. Além de tudo isso, a Bahia, em particular, passava por uma crise econômica devido à forte concorrência no mercado internacional de açúcar, sua principal fonte de riqueza.

É interessante frisar aqui que o espiritismo até então existente no Brasil era o espiritismo de Telles de Menezes, isto é, era uma seleção, ou melhor, era a sua seleção de trechos espíritas que levava o nome de espiritismo. Telles de Menezes, dessa forma, imprimiu neste espiritismo suas recusas e suas aceitações, adaptando-o também às novas teorias científicas e repudiando práticas similares exercidas por adeptos das crenças afrobrasileiras. O projeto espírita de Telles traduzia, portanto, a sua vontade de ajustamento ao novo estilo de vida que então começava a aflorar, ante tantas contradições sociais de um contexto histórico específico e em transformação.

Dessa forma, o espiritismo, ainda que nesse momento visto apenas como uma reforma necessária ao catolicismo - ou seja, ainda não era uma religião propriamente dita - já começava a desempenhar, conforme a igreja católica e as demais religiões, o papel de legitimar o arbitrário e absolutizar o relativo, como diria Bourdieu (2001), de maneira a justificar as situações socialmente determinadas. É como se ocorresse uma alquimia ideológica, porque ao revestir o que é produto humano (portanto uma criação que é arbitrária e relativa a seu tempo) com o caráter sagrado (inquestionável e perene), a religião é capaz de desempenhar a função simbólica de conferir à ordem social um caráter transcendente e inquestionável. É aí que reside sua eficácia simbólica e, ao mesmo tempo, sua função acima de tudo política.

Mas nos enganaremos se pensarmos que as disputas simbólicas pararam por aí. Muito pelo contrário, já que o diálogo entre católicos e defensores do espiritismo apenas começava. A tréplica não tardou a chegar. Só que não veio pelas penas do arcebispo, que atendendo ao pedido de seus fiéis e 
auxiliares, preferiu deixar a peleja a cargo do Pe. Juliano José de Miranda. Responder o próprio arcebispo à carta de Telles de Menezes seria como rebaixar na dignidade arquiepiscopal.

Ocorre que na disputa simbólica, Telles de Menezes não pretendia, naturalmente, acabar com a instituição católica. O apego e o respeito dos primeiros espíritas ao catolicismo aparecem claramente em seus escritos, mostrando que ainda o espiritismo nem pretendia ser uma religião, nem se posicionava no campo religioso enquanto tal, e muito menos estava preocupado em tomar o lugar da Igreja. A força do catolicismo vigorava com espantosa naturalidade entre os primeiros adeptos das idéias espíritas, explicitada nas palavras de Telles de Menezes dirigidas a D. Manuel:

A dignidade do homem, a fé católica e a obediência, que prestamos a V. Exa., como humilde ovelha de seu rebanho, impõe-nos o sagrado dever de patentear a razão, que nos levaram (sic) a esposar a salutar e evangélica doutrina do espiritismo. (MACHADO, 1983, p. 100)

O apelo à razão como forma de ajustar aos novos tempos os velhos dogmas católicos expressava o ideal iluminista do pensamento de Telles de Menezes, ideal retraduzido agora em palavras obsequiosas segundo os limites do campo religioso com dominância católica, por mais contraditório que isso possa parecer. Reconhecer a herança intelectual do Iluminismo presente nas obras de Kardec, e, por conseqüência, na de seus seguidores, é situá-la no bojo do processo de “desencantamento do mundo” (Cf. PIERUCCI, 2003), o que equivale a dizer que havia em suas obras certa repulsa às crenças sobrenaturais; os fenômenos do mundo, ao perderem então o aspecto mágico, passavam a ter, através do trabalho de Kardec, uma significação ordenada segundo um sentido; o “mundo" se tornava, portanto, um problema de “sentido”. Não apenas no método de elaboração o espiritismo é herdeiro do pensamento iluminista: é-o também em toda a teorização espírita. Posto que Kardec, respirando o clima cultural da França do "Século das Luzes”, não poderia trabalhar de outra forma a não ser postulando que "fé inabalável é somente aquela que pode encarar a 
razão, face a face, em todas as épocas da Humanidade”. Essa é nada menos que a epígrafe escolhida a dedo por Kardec para abrir seu Evangelho, $O$ Evangelho segundo o espiritismo.

Comentemos a reação que houve seguidamente à publicação da última obra de Telles de Menezes endereçada ao Arcebispo da Bahia. Como já foi dito, Telles de Menezes teve que publicar uma segunda edição, o que nos faz crer que houve certa procura de seu texto. Uma outra reação: o lançamento de duas obras dirigidas opostamente a ele e, conseqüentemente, contrárias ao espiritismo.

Uma delas foi O Espiritismo. Carta dirigida ao Ilmo. Sr. Luiz Olympio Telles de Menezes, em resposta a que dirigira o dito Senhor ao Exmo. E Revmo. Arcebispo da Bahia D. Manuel Joaquim da Silveira, Metropolitano e Primaz do Brasil. Seu autor chamava-se Manoel da Silva Pereira, um major do exército. Em nome do catolicismo e de seu status e papel na sociedade brasileira, o major justificava sua ação nos seguintes termos:

Foi depois disto [de ler a carta de Telles de Menezes endereçada ao Arcebispo] que deliberei-me a dar uma resposta a V.S. pelas seguintes razões:

Porque entendi e entendo que o sábio e virtuoso prelado não deve vir a imprensa para medir forças em teologia e religião com V.S. que pela sua própria consciência deve confessar o quão grandíloqua é a distância, ou apartamento que em saber deve ir d'Ele a V.S.

Porque se a um leigo em tais matérias é permitido articular com profissional de elevação e reconhecido mérito, muito mais o será a outro leigo, se bem que muito somemos a V. S. a todos os respeitosos.

Porque por aquela razão também o ilustrado clero baiano não deve pronunciar uma só palavra, depois que a cabeça da mesma igreja emitiu seu juízo acerca da questão que se discute. 
Porque finalmente entendo que V.S. está em erro. (FERNANDES, Magali de Oliveira, 1993, p. 107).

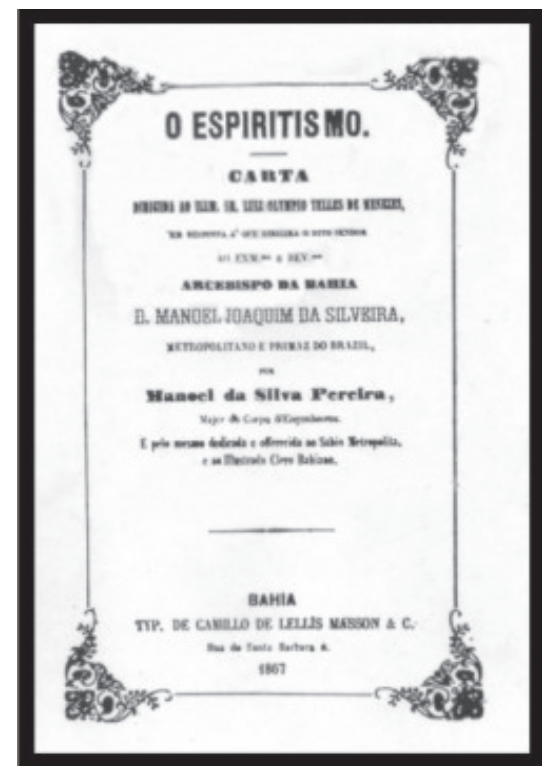

Capa de $O$ Espiritismo de Manuel da Silva Pereira

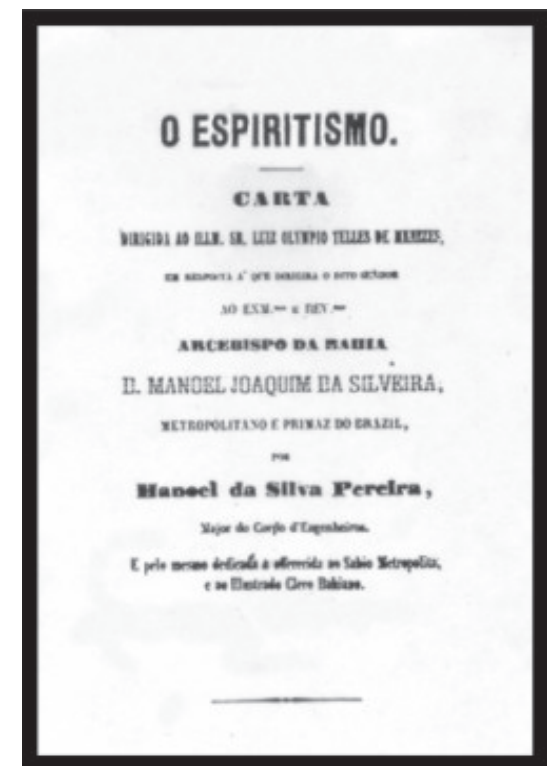

Carta de Manuel da Silva Pereira

A outra obra dirigida a Telles de Menezes foi a Breve Apreciação da Carta do Sr. Luís Olimpio Telles de Menezes Sobre o Espiritismo ao Exmo. e Rev. Sr. Arcebispo, que saiu no segundo semestre de 1867, cujo autor, Juliano José de Miranda, era um padre de apenas 25 anos. Nela Pe. Juliano buscava defender a fé católica e combater o espiritismo com toda a garra de um iniciante quando vê uma chance de tomar posição na disputa. Mais uma vez a preocupação girava em torno das concepções da reencarnação e da preexistência da alma, além do fato mais repudiado por $\mathrm{D}$. Manuel e pelo Antigo Testamento, por ele aclamado: a comunicação com os mortos.

Entretanto, sem o saber, Pe. Juliano e toda a ala católica contrária ao espiritismo acabavam concedendo-lhe espaço no campo religioso ao colocar no e em jogo os conceitos espíritas de espírito e outras noções da teoria espírita. Assim, sem ter consciência do fato, ambos os lados e parcela da sociedade baiana assistiam ao primeiro ato da polêmica entre católicos e os defensores das idéias espíritas. Mas nem todo o clero teria uma atitude semelhante à do Pe. 
Juliano e à do arcebispo da Bahia. Foram muitos os padres que se interessaram pelo espiritismo nessa fase baiana, o que indica a existência de diferentes posicionamentos dentro da igreja católica. O duelo tornava-se cada vez mais empolgante, cada um expondo a sua verdade, dando com isso realce à teoria espírita e também à figura de Telles de Menezes.

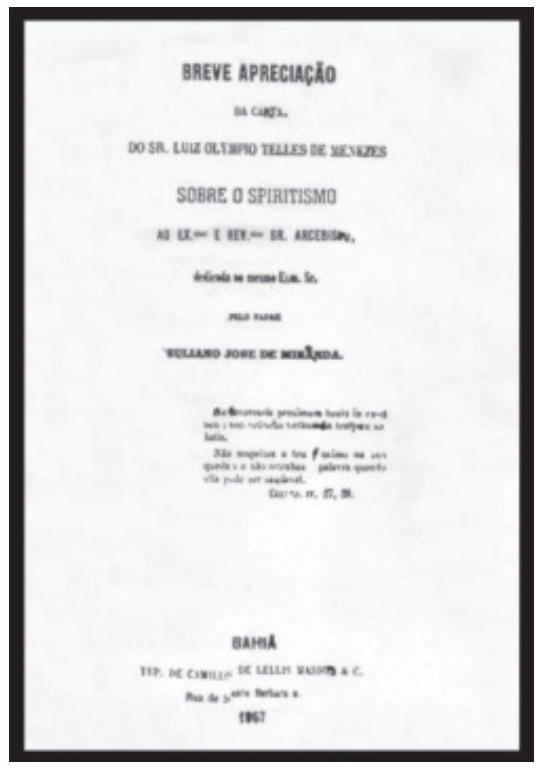

Carta endereçada a Telles de Menezes pelo Padre José de Miranda

Diante desse debate, Telles não se intimidou. Pelo contrário, parecia que era exatamente isso que necessitava para que seus esforços realmente surtissem efeito, sendo, portanto, reconhecidos. Quatro meses depois da publicação do livro de Pe. Juliano, Telles anunciava para todos os espíritas baianos que em breve lançaria aquele que veio a ser o primeiro periódico espírita do Brasil, O Echo d'Além-Túmulo. Assim, utilizando-se desse veículo midiático, estabelecia o dia 17 de setembro de 1865 como o marco da história do espiritismo no Brasil. A esse respeito ele mesmo nos forneceu com precisão alguns dados: "Foi às 11 11/2 horas da noite de 17 de setembro de 1865 que tivemos a inefável felicidade de receber a primeira comunicação espirítica" (IDEM, p. 45). 
Se antes o seu trabalho de tradução e publicação de trechos d'O livro dos espíritos já havia rendido frutos, bem como os seus esforços de criar um periódico, foi exatamente com essa mensagem, recebida e psicografada por ele mesmo, que o seu trabalho religioso tornou-se mais nitidamente seu, próprio ainda que para os espíritas Telles de Menezes tivesse sido tão somente o intermediário, o médium, e não o autor propriamente falando da mensagem. $\mathrm{O}$ espírito que assinou a mensagem - e que outrora já havia se apresentado para Telles de Menezes como ele mesmo afirmou - autodenominava-se "Anjo de Deus”. Telles de Menezes, como que seguindo um procedimento de autenticação da mensagem e comprovação de sua autoria, ratificou: “[...] esse elevado Espírito jurou imediatamente, pelo Sagrado nome da Maria Santíssima, e por Deus Todo Poderoso, ser, efetivamente, o Anjo de Deus" (IDEM, p. 146).

Era ainda uma linguagem extremamente católica que dominava não só o próprio meio espírita, como também o diálogo entre espíritas e católicos, embora o espiritismo tivesse trazido novos vocábulos e novas concepções. De qualquer forma, o fato de ter sido um “Anjo de Deus” o título ou o nome utilizado pelo espírito comunicante aponta que o espiritismo ainda estava bastante vinculado às crenças católicas. "Maria Santíssima”, outro termo originalmente católico, é utilizado no texto como atestação da boa procedência do espírito. Maria, a mãe de Jesus, como se sabe, é para os católicos o símbolo, a marca de distinção, o "logotipo" - se é que assim podemos dizer - do catolicismo, sobretudo frente às demais religiões cristãs.

Mas nessa disputa toda, entretanto, havia um único vilão, assim entendido tanto do lado espírita quanto do lado católico, fato que os fazia conjuminar, neste exato aspecto, a um só lado. Esse vilão era o materialismo. Ser materialista era o mesmo que não ter fala no diálogo nem posto na disputa; era o mesmo que não compartilhar da doxa em questão, ou seja, da fé, entre outras coisas, na existência de Deus e de um mundo imaterial, do “além”. Seu 
afastamento da peleja recém-iniciada foi, portanto, uma das primeiras ações de ambas as partes interessadas e participantes do e em jogo.

Uma vez ressaltados esses aspectos todos, torna-se mais fácil identificá-los como alguns dos pontos iniciais que deram a tônica do processo de formação do incipiente campo religioso brasileiro. Posições, regras, códigos, normas, regulamentos, dinâmica, tudo isso estava sendo construído, delimitado, combinado, definido. E é de acordo com esse processo que se pode entender o porquê de tamanho reconhecimento prestado à figura de D. Manuel. Tanto para o major Manoel da Silva como para o Pe. Juliano de Miranda, o nível conquistado por um arcebispo indicava, no mínimo, o seu grau de credibilidade e juízo no debate. Por isso que um leigo deveria discutir apenas com outro leigo - desde que fosse um leigo crente, claro -, ou no máximo com um padre, hierarquicamente inferior a um arcebispo. Aqui começava, pois, o delineamento, o contorno, um esboço ainda dos diversos tipos de participantes que viriam a se posicionar nessa disputa. Distintas categorias de intelectuais religiosos começavam então a pulular. Correspondendo a diferentes trajetórias sociais e a diferentes funções ocupadas dentro de suas religiões, esses intelectuais ao mesmo tempo em que disputavam entre si, construindo o seu ponto de vista segundo suas coordenadas doutrinárias e teológicas, iam dando corpo, forma e dinâmica própria à luta simbólica em questão. Em todo caso, fosse qual fosse o status ou a distinção que esse intelectual carregasse, ele era sempre incumbido da tarefa de determinar sistematicamente a nova ou a velha doutrina, defendendo-a dos ataques alheios; de delimitar o que é ou não considerado sagrado e de impregnar isto à crença dos leigos a fim de garantir a sua própria existência e a sua própria soberania. É por isso que o interesse na consolidação da própria posição contra possíveis ataques, de um lado, e a necessidade de assegurar a própria prática contra o ceticismo e o materialismo dos leigos, por outro lado, podem levar a resultados semelhantes. Pois como afirma Max Weber (2000a), onde quer que se inicie esse processo, ele acarreta duas conseqüências inevitáveis: a produção de "escrituras canônicas” e a produção de dogmas. 
A repulsa de D. Manuel quanto à questão da evocação dos mortos é extremamente significativa do ponto de vista sociológico. Foi nela que residiu uma das batalhas mais sangrentas, simbolicamente falando, entre os católicos e os espíritas; um grande choque entre duas visões de mundo. É aqui que os dogmas criados entram em combate, veiculados pelas cartilhas, escrituras canônicas, jornais, revistas, catecismos ou qualquer outro tipo de produção material religiosa.

Em toda a teoria espírita a questão da morte é fundamental. Aliás, para o espiritismo a morte não existe tal qual no catolicismo. Para os espíritas, a morte, ou melhor, a desencarnação é simplesmente a passagem que o espírito realiza do mundo material para o mundo espiritual (encarnar, portanto, é a passagem inversa). É nesse sentido que a comunicação com os mortos é simplesmente a comunicação com os espíritos “desencarnados”, estes mesmos que já realizaram a tal viagem. Foi justamente este o ponto da teoria espírita que mais fez estremecer a cúpula católica, totalmente contrária à evocação dos mortos. O processo de retirar os mortos do seu devido lugar - lugar este bem estabelecido e fixado pela Igreja - era o mesmo que mexer com estruturas que deveriam permanecer intocadas. Os mistérios deveriam ser respeitados como tais, como um silêncio, nunca sujeitados a questionamentos ou intervenções. Chamar os mortos e conversar com eles significava para a Igreja o mesmo que questionar as ordens por ela estabelecidas, ordens que freqüentemente iam para além daquelas de natureza religiosa, atingindo o questionamento das próprias estruturas sociais, as mesmas que a Igreja ajudava a legitimar.

Por outro lado, a evocação dos mortos no espiritismo, ao revelar a continuação da vida além-túmulo e, conseqüentemente, a existência das diversas reencarnações, mostrava um mundo sem mistérios, com uma justiça divina mais justa, porque mais igualitária - segundo o ponto de vista espírita -, o que poderíamos dizer mais coerente. Para cada ação (nesta vida), uma reação (na outra): eis a lei, denominada pelos próprios espíritas, de Lei de Ação e Reação, que rege o dogma da reencarnação. Assim, através dessas crenças 
combinadas, a explicação da existência de diferentes camadas sociais seria mais coerentemente desenvolvida pela teoria espírita. O dogma reencarnacionista, ao explicar e justificar, entre outras coisas, que o pertencimento a uma dada camada social é a reação de uma ação anterior, apresentava-se como uma teodicéia mais racional, como diria Max Weber (2000a), ou nas palavras de Pierre Bourdieu (2001), como uma sociodicéia mais racional. O elemento morte (ou seja, desencarnação) no espiritismo, ao trazer consigo a crença nas reencarnações, tornava-se o meio pelo qual se poderia, de um lado, penetrar temporariamente em um reino utópico da igualdade, da universalidade, já que todos, sem exceção, estariam submetidos ao mesmo julgamento; e, de outro lado, explicar o porquê de todas as diferenças e desigualdades sociais, trazendo esperanças e resignação aos socialmente desprivilegiados, e validação e conforto aos socialmente privilegiados. Dessa maneira, as ações de um católico, ou de um sacerdote católico, ou de qualquer outra pessoa seriam igualmente julgadas, já que todos estariam sujeitos aos mesmos tipos de punição ou de recompensa. É por conta disso que o espiritismo trazia em seu conteúdo a promessa da renovação contínua, o tal do renascer: "Naître, mourir, renaître encore et progresser sans cesse: telle est la loi” ${ }^{38}$.

Fundamentava-se, desta maneira, de um lado, o renascimento em uma determinada camada social e, de outro, a possibilidade de melhoria sobre a vida atual e/ou futura. Daí toda uma explicação mais hermética, mais coerente e lógica dada à realidade social. Isso significava se não o rompimento total, pelo menos um grande abalo da estabilidade e da imutabilidade das regras hierárquicas fixadas pelo catolicismo. Porque para a igreja católica, as pessoas estão socialmente posicionadas segundo a vontade indiscutível e inquestionável de Deus, e é dessa forma também que se explicam as desigualdades sociais.

${ }^{38}$ Inscrição reencarnacionista lapidada no túmulo de Allan Kardec localizado no cemitério Père-Lachaise, em Paris, e que quer dizer: "Nascer, morrer, renascer ainda e progredir sem cessar, tal é a lei". 
Isso justifica a subjugação às ordens da Igreja por parte de seus fiéis, já que em última instância questionar a igreja seria o mesmo que questionar a Deus.

D. Manuel e seus seguidores não podiam, portanto, admitir a idéia de evocar os mortos, tampouco o dogma da reencarnação, já que inquiriam as ordens religiosas e, conseqüentemente, a legitimação das ordens sociais pela Igreja asseguradas. Daí a intensificação de um diálogo que apenas começava a se delinear como puramente religioso, posto que era um domínio social ainda em gestação. Foi nesse processo de (des)obstrução da passagem daqueles que traziam novas mensagens, novas crenças e novas idéias, que as doutrinas e os símbolos de diferenciação foram sendo colocados em primeiro plano.

Dessa forma, a luta pela manutenção do monopólio religioso por parte da igreja católica - luta que habita o campo de produção dos bens simbólicos de salvação - contribuía para o próprio fortalecimento da legitimidade em nome da qual ela era conduzida. A Igreja enquanto ortodoxia necessitava da heresia naquele momento específico, porque a oposição entre uma e outra implica sempre o reconhecimento dos interesses que estão em jogo e o próprio asseguramento do jogo. Ao negar uma oposição - o espiritismo - a Igreja ao mesmo tempo em que lhe conferia voz, isto é, espaço na disputa, entreabrindolhe as portas, também se reafirmava no campo onde começava a perder espaço $^{39}$.

As bases da disputa sintomaticamente estavam nos trechos bíblicos. Entretanto, isso acabava conduzindo a certos impasses. As diferentes interpretações criavam barreiras intransponíveis referentes aos postulados de

${ }^{39} \mathrm{Na}$ Constituição outorgada de 1824, a liberdade religiosa era concedida, embora com prerrogativas restritivas. Foi através desse dispositivo que o protestantismo se inseriu no Brasil no Primeiro Reinado (1822-1831), sobretudo o protestantismo de imigração (anglicano e luterano). Mas foi somente durante o Segundo Reinado (1840-1889), a partir dos anos 1870, que o protestantismo de missão penetrou efetivamente em solo brasileiro, respaldado pelos conflitos entre a igreja católica e o Estado cujo corolário foi o episódio conhecido como "questão religiosa" de 1870 (ver nota n. 36). Foram esses alguns dos fatores que começaram a ameaçar o monopólio da igreja católica. 
cada jogador, que amoldava os fatos à sua exegese. Com isso, a leitura herética e a ortodoxa da Bíblia reforçavam justamente dois pontos extremamente importantes para a própria manutenção do campo religioso: a disputa garantia a fé, base indiscutível para a sua existência, e garantia, sobretudo, o trabalho religioso de seus intelectuais. É por isso que o conflito entre a ortodoxia e a heterodoxia, que confere ao campo religioso uma estrutura e a sua história, nunca atingiu o terreno originário da doxa, ou seja, a fé, crença primordial e absoluta manifesta pelos agentes e que põe em funcionamento o próprio campo. D. Manuel Joaquim da Silveira, Padre Juliano José de Miranda, Manoel da Silva Pereira e Luís Olímpio Telles de Menezes eram, portanto, o que poderíamos chamar de adversários cúmplices.

Pensando nisso é que se pode dizer também que o êxito da empresa tão almejado pelos envolvidos na disputa consiste exatamente em adquirir para seu trabalho e para si a força da crença, ou seja, a fé - um reconhecimento absoluto. Para tanto, é necessário existir uma espécie de poder “mágico” na relação entre 1) os interesses dos participantes, 2) o poder simbólico que manipulam e 3) a crença dos demais nesse poder. Pois para que esse poder se perpetue, isto é, para que a fé exista, os agentes especializados nesse trabalho têm que conseguir mantê-la desconhecida, ou seja, evidente. Mas não só para garantir a fé; dessa maneira eles também garantiam a sua própria existência e validavam o seu próprio trabalho religioso. Assim, os seus investimentos no jogo, isto é, as lutas que travaram e que tem por finalidade obter o monopólio da definição do modo legítimo de produção dos bens de salvação, contribuíam para reproduzir continuamente a crença no jogo, o interesse pelo jogo e pelas apostas; lutas estas que são, pelo menos parcialmente, o produto do próprio jogo.

Engajados na difusão do espiritismo, Telles de Menezes e seus adeptos resolveram pedir, em 24 de agosto de 1871, através de um documento com trinta assinaturas endereçado ao Vice-Presidente da Província da Bahia, Dr. 
Francisco José da Rocha, uma autorização para o funcionamento da Sociedade Espírita Brasileira. O pedido foi negado pelo parecer de ninguém menos que D. Manuel Joaquim. Pois, embora a Constituição do Império, no seu art. 59, permitisse a coexistência de outras religiões, desde que tivessem apenas cultos domésticos ou particulares em casas para isso destinadas e sem forma alguma exterior de templo; e embora ainda estabelecesse (art. 179, § 5) que ninguém podia ser perseguido por motivo de religião, uma vez que respeitasse a do Estado e não ofendesse a moral pública, praticamente impossível era, na época, a aprovação pelo Governo dos estatutos de sociedade religiosa que não fosse católica, já que, em razão do Decreto 2.711 de 19 de dezembro de 1860, todas as sociedades religiosas, científicas, políticas ou quaisquer outras, tinham que obter a aprovação antecipada do Ordinário na parte espiritual.

O argumento de D. Manuel não poderia ser outro que o católico, isto é, político-religioso, apesar de Telles de Menezes ter apresentado a sua sociedade enquanto uma sociedade literária e beneficente. Todavia, ainda que não tivesse tido caráter religioso e que Telles de Menezes tivesse preferido qualificá-la daquela maneira, isto de nada lhe valeu, sendo o processo deferido em 1872 . O espiritismo era, assim, “um atentado formal contra a verdade católica [...]. Uma sociedade, cuja doutrina tem por fim contrariar a Religião do Estado, é contra o mesmo Estado” (MACHADO, 1983, p. 98). Importa aqui não perder de vista que o arcebispo falava em Religião do Estado, logo mobilizando uma indistinção de esferas “pré” liberdade religiosa. É um argumento religioso, mas não puramente religioso, pelo fato mesmo de não haver ainda um campo religioso constituído.

Desejando os espíritas baianos organizarem-se em sociedade com estatutos aprovados pelo governo, o que lhes garantiria certos direitos constitucionais, foi isto interpretado pelo clero de maneira religiosa, levantando-se a idéia de que as sociedades espíritas queriam agora professar uma nova doutrina religiosa com a aprovação do governo. Foi aí que depois de um ano, em 28 de novembro de 1873, os componentes do grupo espírita, a fim 
de alcançarem permissão para existir, constituíram-se dessa vez enquanto sociedade científica, com o nome de Associação Espirítica Brasileira, regida pela quase totalidade das disposições estatutárias da referida Sociedade Espírita Brasileira e que foram também submetidas à aprovação governamental, só que desta vez aceitas. Tomando por base os princípios contidos no Livro dos espíritos e no Livro dos médiuns, a nova associação, agora científica, tinha como fim o desenvolvimento moral e intelectual do homem nas bases que possibilitava a teoria espírita. Telles de Menezes, que havia se colocado à frente dessa instituição, foi seu primeiro presidente e, pouco depois, ganhou o título de presidente honorário.

Tempos mais tarde, em um relatório apresentado por ele à Associação Espirítica Brasileira, aos 17 de setembro de 1874, lamentava a débil difusão do espiritismo em terras brasileiras visto que, apesar de seus esforços,

Os preconceitos, infelizmente arraigados no ânimo do maior número, têm sido um dos grandes obstáculos à propagação das salutares e regeneradoras doutrinas da filosofia espirítica. A fiel exposição dessas doutrinas não está ao alcance das multidões, porque as obras fundamentais não se acham traduzidas na língua vernácula; entretanto, preciso é aqui notar o valioso serviço que prestou O Echo d'Além-Túmulo - cuja publicação foi interrompida -, levando a idéia espirítica a todos os pontos do Brasil, de modo que hoje já se agita ela em todas as províncias, e já nalgumas se têm formado grupos $e$ sociedades, como no Pará, Maranhão, Pernambuco e no Rio de Janeiro, onde as idéias espiríticas mais extensamente têm progredido [...]. (WANTUIL, 2002, p. 585, grifos nossos).

Telles expunha em seguida e mais enfaticamente a importância da vulgarização das obras fundamentais de Allan Kardec, aquelas da “codificação”, atividade que ele mesmo já havia iniciado anos antes, revelando que o movimento no Rio de Janeiro

se tem tornado tão pronunciado que a Livraria Garnier foi autorizada a traduzir em português as importantes obras de Allan 
Kardec, e sou informado de que em breve, sessenta dias quando muito, sairá à luz O Livro dos Espíritos, essa obra fundamental, base da filosofia espirítica (IDEM, p. 586, grifos do autor).

Acontecia que o espiritismo até aquele momento não encontrara uma forma definida de se firmar em terras brasileiras. Mesmo para Telles de Menezes, nada estava claro. A teoria “espirítica” era apresentada por ele ora como doutrina religiosa, ou melhor, como uma reforma de alguns pontos do catolicismo, ora como ciência com implicações morais, ora como filosofia. Daí entender como o espiritismo ainda não se posicionava enquanto religião; tampouco estava no campo filosófico; e no campo científico também não conseguiu fixar-se, recebendo vários ataques discriminatórios. O movimento espírita baiano não pôde institucionalizar o espiritismo, não obstante, com Telles de Menezes à frente, chamou a atenção do restante de outras partes do Brasil e concorreu para repropagar e formatar as idéias espíritas na Corte.

\section{Afinal, espiritismo é religião?}

O espiritismo já era, então, conhecido por parte da nata social, camada na qual havia conquistado admiradores e praticantes. A princípio, o que mais lhes interessou e lhes chamou atenção foram as manifestações “magnéticas”, sonambúlicas e hipnóticas, dado o momento fortemente marcado pela influência cientificista. E mesmo contando com o interesse de tão alta estirpe, como por exemplo, de Manuel de Araújo Porto Alegre, Barão de Santo Ângelo, o espiritismo era estudado e praticado de forma ainda velada. Isso porque, enquanto teoria composta de uma face religiosa, começava a sofrer o repúdio da igreja católica, ciosa de manter o monopólio religioso; enquanto agente provocador de fenômenos físicos, era acusado pelo campo científico de fraudulento e explorador da credulidade pública.

As suas várias formas de aceitação provocaram a formação de diversos grupos, uns interessados mais nos estudos filosóficos, outros nos científicos e 
outros ainda nos seus princípios morais. A dispersão do espiritismo em vários segmentos mostra como ainda não havia naquele momento uma definição legítima do que seria espiritismo e em qual campo ele iria atuar. Kardecistas, místicos, espíritas puros, roustainguistas, científicos, swedenborguistas, entre outros, eram as subdenominações dos diversos agrupamentos que o esposaram, cada qual enfatizando uma de suas facetas.

Dessa forma, o panorama do espiritismo brasileiro no final do século XIX se mostrava bastante rico, pelo menos no que diz respeito à quantidade de grupos que o seguiam. Muitos espíritas defendiam a posição de que se deveria estudar apenas $O$ livro dos espíritos, sendo o espiritismo encarado apenas como ciência. Os estudiosos dos demais livros de Allan Kardec eram chamados de kardecistas (ABREU, 1996a, p. 9). Assim, o grupo dos científicos, também chamado de Espiritismo Científico, que abrangia subgrupos, tendo destaque os Psiquistas e os Ocultistas, estava exclusivamente preocupado com o que chamavam de experiência fenomenológica. Sua atenção estava voltada para os “fenômenos” espíritas, ou seja, para as aparições dos espíritos e seus efeitos (materialização, sonambulismo, hipnotismo). Desprezavam a filosofia espírita e principalmente o seu aspecto religioso.

O grupo dos místicos ou religiosos era o mais numeroso, abrangendo os subgrupos que estavam mais preocupados com o lado religioso do espiritismo, atendo-se à moral cristã. Dentre os subgrupos, destacavam-se os roustainguistas, os ismaelinos, os kardecistas, os teosofistas e os swedenborguistas (IDEM).

Espiritismo Puro significava que nem era científico, nem místico ou religioso. O grupo se encontrava no centro das duas definições, mas com tendências ao olhar mais filosófico; foi o que menos força teve na disputa simbólica da definição do que era (ou não) espiritismo. Talvez por ser o mais tolerante, não investiu pesadamente nesse jogo assim como o fizeram os científicos e os místicos. Além disso, o campo filosófico era bastante precário no Brasil, não chamando o espiritismo a atenção dos quase inexistentes 
adversários filósofos, diferentemente dos muitos adversários cientistas e católicos.

Se é fato que o espiritismo, por ter ascendência européia, carregava consigo certo prestígio que pode ter facilitado seu expandir-se nas camadas mais privilegiadas de então, sua origem européia, por outro lado, e o peso legitimador dessa origem parecem ter pesado menos que o fato dele ter desenvolvido uma conformação específica no processo de sua inserção em um novo quadro social de relações, por isso romper com a fonte inicial num rearranjo sob as novas condições. É nesse processo que entram os diversos grupos e a disputa que travaram entre si com o objetivo de alcançar a primazia do discurso "espírita". Dessa forma, a produção intelectual do que iremos denominar "movimento espírita” só pode ser entendida segundo a sua natureza mediadora num campo mais abrangente de relações e de posições sociais. Os agentes encarregados da defesa de suas posições no meio espírita - os intelectuais espíritas - posicionavam-se feito partículas num campo de forças, e suas trajetórias e disposições foram determinantes nesse processo. Em meio a tais disputas, coube a alguns agentes especializados produzirem os instrumentos e os meios adequados à organização, transmissão e inculcação de uma doutrina cada vez mais assumidamente "doutrina”, ou seja: cada vez mais "inventada” como religião. Assim, a produção de instrumentos tais como jornais, revistas, diários, boletins, informativos, congressos, livros, dogmas, agremiações, sociedades etc., foi tanto maior nas situações iniciais de introdução por que passou o espiritismo quanto mais necessário se fez enfrentar as vertentes concorrentes ${ }^{40}$.

${ }^{40}$ Entre os meses de janeiro e março de 1904, foram publicadas na Gazeta de Notícias as reportagens do jovem jornalista Paulo Barreto sob o pseudônimo de João do Rio. Elas receberam o nome de "As religiões no Rio" e saíram, mais tarde, em formato de livro com título homônimo pela livraria Garnier. Encontram-se nesse livro dados sobre as religiões na então capital brasileira. Sobre o espiritismo tem-se à página 270 da edição de 2006 da editora José Olympio: "A Federação [Espírita Brasileira] publicou uma estatística de jornais espíritas do mundo inteiro. Pois bem: existem no mundo 96 jornais e revistas, sendo que 56 em toda a Europa e 19 só no Brasil. [...] E quais são essas revistas e jornais? 'Mensageiro', 


\section{Dispersão e disputa}

Em 2 de agosto de 1873 surgia a primeira sociedade espírita da Corte, Sociedade de Estudos Espiríticos - Grupo Confúcio ${ }^{41}$, dedicada ao "estudo dos fenômenos relativos às manifestações espíritas, bem como o de suas aplicações às ciências morais, históricas e psicológicas” (WANTUIL, 2002, p. 121). Entre os seus fundadores estavam homens de elevada estirpe social. Sua primeira diretoria foi composta pelo Dr. Siqueira Dias, presidente; Dr. Antônio da Silva Neto, vice-presidente; Dr. Joaquim Carlos Travassos, secretário geral; Sr. Eugênio Boulte, $2^{\circ}$ secretário; Sr. Marcondes Pestana, $3^{\circ}$ secretário; Casimir Lieutaud, tesoureiro; Dr. Francisco Leite de Bittencourt Sampaio, Mme. Perret Collard e Mme. Rosa Molteno, membros do Conselho Fiscal.

Um dos mecanismos mais eficazes postos em prática pelo Grupo Confúcio foi a tradução das obras de Allan Kardec. Coube então ao médico, o Dr. Joaquim Carlos Travassos, a tarefa de trazer à língua portuguesa $O$ livro dos espíritos, traduzido da $20^{a}$ edição francesa, sem data de publicação, com o pseudônimo de Fortúnio; O livro dos médiuns, em 1875, traduzido da $12^{\mathrm{a}}$ edição francesa, sem o nome do tradutor; O céu e o inferno, em 1875, traduzido da $4^{\text {a }}$ edição francesa, sem o nome do tradutor; $O$ Evangelho segundo $o$ espiritismo, em 1876, traduzido da $16^{a}$ edição francesa, sem o nome do tradutor. Todas essas quatro obras foram dadas à luz por intermédio da Editora

em Manaus, Amazonas. 'Luz e Fé' e 'Sofia', em Belém, Pará. 'A Cruz', em Amarante, Ceará. 'A Semana (ciências e letras)', no Recife, Pernambuco. 'A Verdade', em Palmares, Pernambuco. 'O Espírita Alagoano', 'A Ciência', em Maceió, Alagoas. 'Revista Espírita' em São Salvador, Bahia. 'Reformador', no Rio de Janeiro. 'Fraternização, Verdade e Luz', 'A Nova Revelação', 'O Alvião' e a 'Doutrina', em Curitiba, Paraná. 'Revista Espírita', em Porto Alegre, Rio Grande do Sul. 'A Reencarnação', no Rio Grande. 'O Allan Kardec', em Cataguases, Minas Gerais. [...] Ainda em 1900, no seu relatório ao Congresso Espírita e Espiritualista de Paris, a Federação acusava adesões de 79 associações e o aparecimento de 32 jornais e revistas de propaganda [...]."

41 "Confúcio" era o nome de um "espírito protetor" em cujas comunicações dizia-se enviado do Anjo Ismael, este considerado como o guia protetor do Brasil (WANTUIL, 2002, p. 119-121) - sobre o assunto sob o ponto de vista espírita, ver a obra de XAVIER (1990). 
B. L. Garnier, editora conceituada na época, composta, entre outros editores, por Bittencourt Sampaio, magistrado, político, jornalista, literato e, além de todas essas funções, também membro do Conselho Fiscal do Grupo Confúcio; Bittencourt foi um espírita que em muito influenciou na formatação do espiritismo no Brasil, como veremos mais adiante.

Embora tenha sido obra do Dr. Joaquim Carlos Travassos a tradução de quatro dos cinco livros da "codificação" de Allan Kardec, o Grupo Confúcio, conforme o art. 28 de seu estatuto (ABREU, 1996a, p. 36; WANTUIL, 2002 p. 121), adotava como base de seus estudos somente $O$ livro dos espíritos e $O$ livro dos médiuns, o que conferia a seus adeptos, pelo menos naquele momento, a classificação de espíritas puros. O artigo dizia que o Grupo seguiria os princípios e as formalidades expostas nesses dois livros, conformando-se com as diretrizes adotadas pela Societé Anonyme du Spiritisme, uma sociedade francesa que tinha como objetivo continuar com a divulgação das obras espíritas de Allan Kardec pelo mundo.

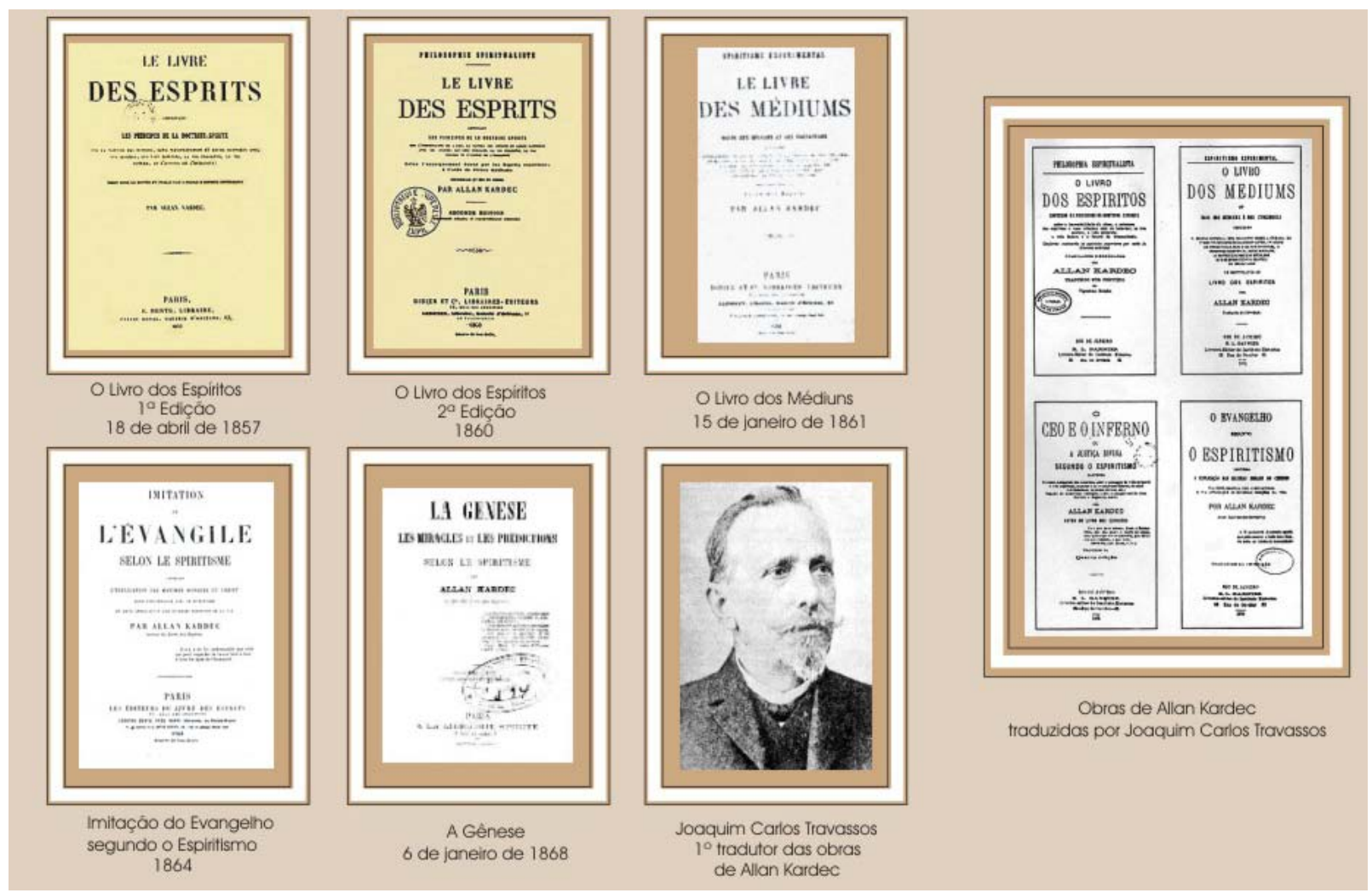


Mas para propagar a doutrina eram necessários também aparelhos responsáveis pela circulação das idéias, daí a criação da Revista Espírita, “publicação mensal de estudos psicológicos”, editada entre os anos de 1875 e 1876, cujo conteúdo abrangia desde artigos traduzidos da Revue Spirite e de outros jornais estrangeiros, até comentários e explanações doutrinárias. Antônio da Silva Neto, fundador da revista, escrevia na primeira edição: “ $O$ Espiritismo é uma ciência de observação; portanto está comprometido no quadro das ciências positivas" ${ }^{42}$.

Antônio da Silva Neto, participante empenhado dos movimentos abolicionista e republicano, diplomou-se em Matemática e Ciências Físicas pela Escola Politécnica no Rio de Janeiro. Fora um dos signatários do Manifesto Republicano de 1870 e articulista do jornal A República, além de ter publicado alguns livros pela Editora Garnier. O mais significativo em sua trajetória foi sua adesão à filosofia positiva de Auguste Comte, pois apesar da educação familiar católica, Silva Neto não admitia qualquer crença que conflitasse com os postulados científicos correntes à época. Assim, por formação, privilegiou a parte científico-filosófica da teoria espírita. Mas apesar do seu trabalho de defesa do espiritismo principalmente frente à imprensa, a revista teve curta duração, bem como o Grupo Confúcio, que se extinguiu em 1879. Aliás, três anos antes o grupo já havia sofrido com a dissidência de alguns membros, os mesmos responsáveis pela fundação da Sociedade de Estudos Deus, Cristo e Caridade, dirigida por Bittencourt Sampaio e pelo advogado Antônio Luiz Sayão, ambos mais interessados no aspecto religioso do espiritismo. Entretanto, essa sociedade, por sua vez, também sofreria, tempos depois, com disputas internas; a divisão entre os seus membros provocou uma separação irreconciliável entre os que davam preeminência ao fator religioso e os que pretendiam fazer do centro uma quase academia de ciência, mesma divisão que havia provocado o fim do Grupo Confúcio. Assim, o nome da sociedade passou a ser Sociedade Acadêmica Deus, Cristo e

\footnotetext{
${ }^{42}$ Revista Espírita, no. 1, janeiro de 1875.
} 
Caridade (o mesmo nome dado à revista dirigida pelo grupo, lançada em 1881), atendendo à vontade do grupo dos científicos e tendo à frente o professor Angeli Torterolli, uma das figuras mais expressivas entre os científicos daquela época, mas uma das mais desconhecidas do movimento espírita atual, por mais estranho que isso possa parecer hoje. Pedro Richard, com o pseudônimo de "Discípulo de Max" ${ }^{43}$, um espírita religioso, lamentou o fato anos mais tarde dizendo que não era possível conceber o espiritismo dessa forma: "Como se Deus, Cristo e Caridade pudessem ser acadêmicos, colegas de pobres pecadores ignorantes" ${ }^{44}$.

O projeto da Sociedade Acadêmica ia longe; era extenso, mas bem delimitado. Além da revista,

órgão oficial da Sociedade Acadêmica, redigida pela sua Diretoria, levando aos seus Membros o conhecimento das resoluções e deliberações administrativas e transmitindo o resultado dos estudos e trabalhos da ACADEMIA ESPÍRITA DE CIÊNCIAS, tem por fim preencher as vistas sociais - o Progresso da Humanidade ${ }^{45}$;

os integrantes da Sociedade Acadêmica pretendiam também construir uma biblioteca e um museu. E assim, definiam seus projetos:

- A REVISTA dará publicidade gratuitamente aos trabalhos científicos ou filosóficos que nos forem remetidos [...] Todos os trabalhos serão acolhidos com agrado, e mais especialmente os científicos de fundo espiríticos [...]. Assim, a Revista admitirá nas suas páginas, da primeira à última, artigos não só dos Espíritas, mas também de quaisquer colaboradores, desde que venham envoltos na toga da ciência ou no manto do cavalheiro;

${ }^{43}$ Max era o pseudônimo do médico Adolfo Bezerra de Menezes, espírita bastante reconhecido no meio e sobre o qual falaremos no capítulo seguinte.

${ }^{44}$ Reformador, 15 de setembro de 1901.

${ }^{45}$ Revista Espírita da Sociedade Acadêmica Deus, Cristo e Caridade, janeiro de 1882. 
- A BIBLIOTECA da Sociedade Acadêmica destinada a conter obras sobre todos os ramos do conhecimento [...];

- Na sala que a Sociedade Acadêmica consagrou à União Espírita Universal, haverá no quarto domingo de cada mês, ao meio dia, uma conferência espírita, na qual poderá subir à tribuna livre qualquer cavalheiro que se tenha inscrito, mesmo para contestar o Espiritismo;

- O MUSEU HISTÓRICO-FILOSÓFICO fundado para representar a evolução intelectual e moral da humanidade aceita todos os objetos que lhe forem remetidos; agradecendo à Comissão Confraternizadora as ofertas, em nome da Sociedade no progresso da família terrestre $^{46}$.

Antônio Luiz Sayão que tentara, sem êxito, recompor a antiga Sociedade de Estudos Deus Cristo e Caridade, acabou fundando com Frederico Júnior, João Gonçalves do Nascimento, Bittencourt Sampaio entre outros, o Grupo Espírita Fraternidade (1880), que mais tarde, após outra dissidência, veio a se chamar Grupo Ismael, uma das agremiações mais importantes de espíritas cariocas, integrada tempos depois à Federação Espírita Brasileira, fundada em 1884.

Enquanto isso, a Sociedade Acadêmica Deus, Cristo e Caridade promovia, no dia 6 de setembro de 1881, no Rio de Janeiro, o $1^{\circ}$ Congresso Espírita Brasileiro, cuja finalidade era reunir os grupos espíritas existentes na capital e, se possível, no país. Nesse congresso foi criado o Centro da União Espírita do Brasil, a primeira instituição que se pretendeu unificadora do movimento espírita nacional. Sua instalação oficial deu-se no dia 3 de outubro daquele ano, sob a direção do professor Afonso Angeli Torterolli, também fundador, em 28 de agosto de 1882, do jornal O Renovador, juntamente com o

${ }^{46}$ IDEM. 
Major Salustiano José Monteiro de Barros. A edição de novembro da revista da Sociedade Acadêmica fez a relação dos grupos filiados até aquele mês.

A Diretoria Central [...] tomando em consideração a deliberação aprovada na sessão ordinária n. ${ }^{\circ} 812$ do Congresso Espírita do Brasil, composto dos representantes de todas as sociedades, grupos e jornais espíritas que existem no território do Brasil e estão filiados ou representados perante o Centro, e em cumprimento dos estatutos vem solicitar o valioso concurso de todos os espíritas, a fim de fortificar os laços de solidariedade fraternal da Família Espírita Brasileira para ligá-la à Família Espírita Universal, empregando os meios compatíveis com o fim tão santo, do qual resultará o progresso moral da humanidade, a fraternidade e a paz universal sob o lema: Deus, Amor e Liberdade ${ }^{47}$.

No entanto, o Centro da União não passou de mera tentativa. Devido à própria incipiência do movimento espírita e aos conflitos que, àquela época, dividiam os vários agrupamentos, a instituição acabou se desorganizando. Como o Centro da União estava sob a direção do científico Angeli Torterolli, é bem possível que os religiosos, também denominados místicos, tenham boicotado o projeto, já que as divergências entre esses dois pólos foram as maiores responsáveis pelo clima de desunião entre os espíritas.

${ }^{47}$ Reproduzido no Reformador, 01 de agosto de 1896 (grifos do autor). Havia neste periódico um espaço reservado para a publicação de assuntos referentes a outros órgãos que não a Federação Espírita Brasileira, à qual era diretamente ligado. Assinaram o documento, entre outros, Antônio Pinheiro Guedes, Augusto Elias da Silva, Angeli Torterolli, Carlos Joaquim de Lima e Silva e Júlio César Leal. 


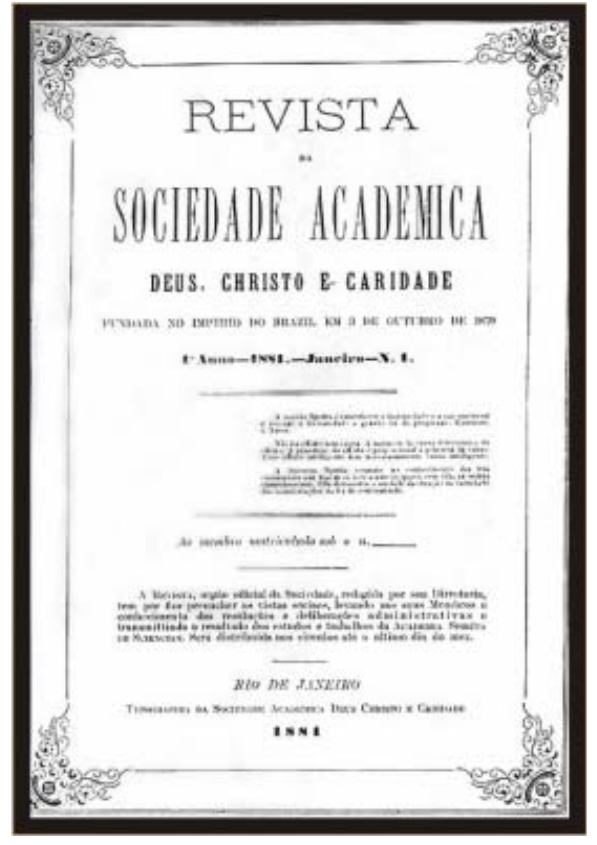

Revista da Sociedade Acadêmica Deus, Christo e Caridade

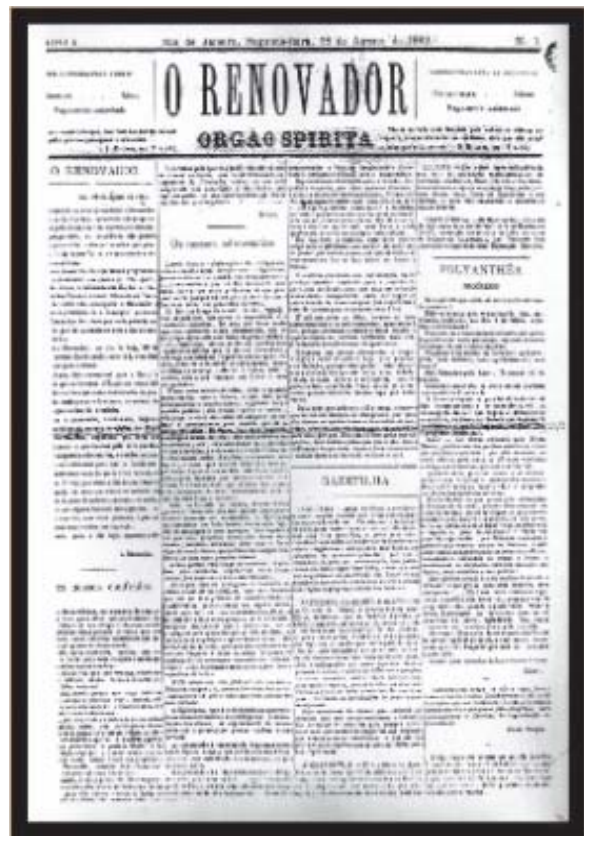

O Renovador

Antes de seu fim, porém, no ano de 1882, a Sociedade Acadêmica, um grupo, portanto, majoritariamente científico, publicou a primeira edição de $L a$ gènese em português. No prefácio, lia-se o seguinte:

[...] conquanto alguns condiscípulos mostrassem o desejo de que modificações fossem feitas em certos pontos deste volume, de acordo com as idéias manifestadas na obra OS QUATRO EVANGELHOS [...], publicamos a presente tradução de A GÊNESE sem a mínima alteração e mesmo sem anotações [...]. A Sociedade Acadêmica julga que não lhe assiste, como a ninguém, o direito de alterar o plano e, menos ainda, as bases fundamentais [...] das obras publicadas pelo nosso mestre $[\ldots]^{48}$

Ocorria que, por afinidades eletivas, a quase totalidade dos religiosos ou místicos partilhava das idéias e crenças apresentadas em Espiritismo cristão ou revelação da revelação. Os quatro evangelhos (1866), livro de autoria do

\footnotetext{
${ }^{48}$ Disponível em:
}

<http://www.universoespirita.org.br/NOVA ERA/BREVE HISTORIA.htm>. Acesso em: 10 maio 2007. 
advogado francês de Bordeaux, Jean-Baptiste Roustaing (1805-1879), enquanto a maior parte dos ditos científicos as repudiava, muito embora houvesse tido exceções de lado a lado ${ }^{49}$.

Desde o século XIX, as teses do advogado bordelês contribuíram, como veremos mais adiante, para dificultar a unificação do movimento espírita. Aliás, o critério de adoção ou não de suas idéias foi justamente um dos pontos mais discutidos, mesmo entre os próprios religiosos, pois havia aqueles que também não as aceitavam.

Juntamente com esses grupos proliferavam vários outros, sendo comum a presença da mesma pessoa em vários deles, indicando que, apesar da diversidade de interpretações e de práticas filiadas ao espiritismo, é difícil reduzi-las, engessando-as às categorias criadas pelos próprios espíritas científicos, místicos, puros etc. - categorias que colocam em jogo os temas em disputa, mas que não se excluem mutuamente. Convém salientar que entre os espíritas as ações de auto-classificação e, conseqüentemente, de desclassificações mútuas não foram atos isolados, mas um processo no qual se percorre uma seqüência de elos significativos. Mas admitir que não houvesse interferências entre eles seria ignorar a própria experiência prática. Mais apropriado seria então afirmar que havia um campo comum no qual os diversos adeptos transitavam com bases na tematização "ciência”, "filosofia” e "religião" em suas variegadas e complexas articulações. Mas para efeitos de análise desse processo, é importante enfatizar então que tais classificações só são entendidas aqui neste trabalho em termos típico-ideais ${ }^{50}$.

${ }^{49}$ Falaremos mais à frente sobre essa disputa no Capítulo III.

50 Assim entendida, a tipologia weberiana, quando se trata de explicar uma "constelação histórica singular" (uma figuração, na concepção de Norbet Elias), não se propõe enquanto um instrumento de prova que deve tomar o lugar do trabalho histórico. As construções dos tipos ideais neste trabalho (um primeiro passo) prestam o serviço de conduzir-nos a formulações de hipóteses e sugerir as questões a serem colocadas à realidade. Entretanto, um segundo passo é necessário se quisermos revelar e compreender as relações muitas vezes ocultas entre os agentes sociais e as nuances mais sensíveis de 
Por volta de 1889 havia cerca de 35 grupos espíritas só no Rio de Janeiro (GIUMBELLI, 1997a, p. 62), fato que revela um movimento bastante disperso. Eram membros desses diversos grupos médicos como Joaquim Carlos Travassos, Adolfo Bezerra de Menezes; homeopatas como Antônio Pinheiro Guedes e Francisco Menezes Dias da Cruz; engenheiros como Antônio da Silva Neto; advogados como Julio César Leal, Ernesto dos Santos e Luis Antônio Sayão; literatos, como Bittencourt Sampaio; militares como Raimundo Ewerton Quadros; funcionários públicos como Carlos Joaquim Lima e Cirne, ou autônomos, como o jornalista Augusto Elias da Silva e o professor Affonso Angeli Torterolli. A maioria dos principais líderes espíritas, portanto, ocupava posições sociais relativamente privilegiadas, o que garantia aos grupos de que participavam a possibilidade de se beneficiarem de recursos materiais e de redes de relações importantes para a legitimação da causa espírita.

Assim, por conta do fracasso iminente do Centro da União causado pelas divisões internas do movimento espírita, Augusto Elias da Silva, criador do periódico O Reformador, em 1883, à época um simples jornal, começou a pensar na fundação de um outro centro unificador. Foi então que no dia 27 de dezembro do mesmo ano, realizou uma reunião com 12 companheiros que o ajudavam no jornal. Aí, neste encontro, o grupo decidiu fundar uma nova instituição que não fosse nem mística nem científica. A fim de congregar todos os grupos existentes, ela deveria ser ideologicamente "neutra”. Por conseguinte, no dia $1^{\circ}$ de janeiro de 1884, os seus integrantes fundavam a Federação Espírita Brasileira (FEB) cujo primeiro presidente foi o Marechal Francisco Raimundo Ewerton Quadros. Com a intenção deliberada de provar a neutralidade da nova sociedade, já que na realidade a maior parte do grupo era religiosa, foram convidados a se cadastrarem como sócios-fundadores Angeli Torterolli e Joaquim Távora, ambos explicitamente científicos.

ação e de relação entre eles. Desta forma, mediante uma análise interacionista das relações entre os agentes aqui analisados, é cabível a proposta da construção de uma estrutura de relações objetivas, que explicaria de forma mais concreta as interações e os tipos de intervenções originalmente descritas em formato de uma tipologia. 
Assim, o movimento espírita só começaria a se unificar, a se definir e a se legitimar com o surgimento de uma associação que se pretendesse “reguladora e unificadora das idéias espíritas”; uma entidade que se propusesse a "representar os diversos grupos e a ser o instrumento de divulgação do espiritismo”. Foi, portanto, exatamente nesses termos que a Federação Espírita Brasileira se apresentou e foi através do labor incansável de seus dirigentes que ela conseguiu se firmar no cenário brasileiro, muito embora houvesse existido anteriormente uma tentativa de unificação com a criação do Centro da União Espírita do Brasil, fracassada talvez pela falta de capital social de seus líderes e diretores, e mesmo pela falta de espaço para o teor de discussões por eles propostas.

Foi desta maneira que os esforços pioneiros de coesão de algumas sociedades e grupos acabaram por implantar os primeiros núcleos espíritas mais bem estruturados, guiados, sobretudo, pelas fontes inspiradoras da França. Mas a barreira da língua era um fator bastante limitador ao acesso às obras originais francesas, restrito a poucos conhecedores do idioma. Assim fica fácil entender que somente aqueles que possuíam o domínio da língua francesa conseqüentemente possuíam também o poder de escolher qual obra ler, traduzir e divulgar. Nesse contexto, os núcleos espíritas através de seus agentes delineavam seus rumos, principalmente pela utilização da imprensa espírita. Muitas traduções de artigos e de trechos de livros franceses encontraram nela um meio privilegiado de vir à luz, meio disponibilizado por espaços especialmente concedidos para esse fim. Foi, portanto, a imprensa um mecanismo fundamental de divulgação dos diversos “espiritismos” ${ }^{51}$, apesar da

51 Hoje no Brasil o papel que a imprensa espírita possui é fundamental e indispensável para a circulação das idéias espíritas. Há atualmente um elevado número de editoras dessa ordem cuja quantidade pode chegar a centenas. Só a FEB possui mais de 400 títulos de obras espíritas, além de publicar o centenário periódico O Reformador. A título de exemplo, tem-se as editoras (as mais conhecidas): Edições Leon Denis, Aliança, LEAL, Casa dos Espíritos, Inede, Editora Didier, IDEAL, Dufaux, Fundação Lar Harmonia, Edições Clareon, FEB, LAKE, IDE Editora, Casa Editora O Clarim, GEEM, Paidéia, Editora Allan 
maior parte de periódicos de fins do século XIX ter tido duração efêmera, com exceção apenas de um, O Reformador. A Revista Espírita, por exemplo, fundada em 1875 e dirigida por Antônio da Silva Neto, vice-presidente do Grupo Confúcio, durou apenas seis meses. Outra tentativa, a Revista da Sociedade Acadêmica Deus, Cristo e Caridade, subsistiu apenas de janeiro de 1881 até o final do ano de 1882.

Nesse movimento todo, investiu consideráveis esforços o fotógrafo de profissão, Augusto Elias da Silva. Com o apoio e o incentivo de sua sogra e de sua esposa, ambas também espíritas, Elias da Silva idealizou e lançou, em 1883, o jornal O Reformador. Recebera também a cooperação e o indispensável auxílio de alguns companheiros, dentre eles, o de Marechal Ewerton Quadros, primeiro presidente da FEB e primeiro tradutor para a língua portuguesa da obra de J.-B. Roustaing, tarefa que teve início em 1883. Foi justamente $O$ Reformador o órgão que começou a publicá-la a partir de 15 de janeiro de 1898, só o fazendo parcialmente.

Elias teve o seu primeiro contato com as manifestações espíritas no ano de 1881, dois anos antes de fundar o seu jornal. Narrou ele mesmo a sua experiência:

Em 1881, fui convidado a assistir a uma sessão [espírita] na sala da Sociedade Acadêmica Deus, Cristo e Caridade, rua da Alfândega $n^{\circ}$. 120. As minhas convicções nesta época eram as do mais lato indiferentismo religioso, não tendo a menor parcela de dúvida sobre a não existência da alma. Não admitindo os fenômenos das diversas religiões, só via nelas agrupamentos de ociosos e amigos de dominar, explorando a ignorância das massas, geralmente supersticiosas e inclinadas ao sobrenatural. [...] A essa sessão assistiam umas cinqüenta pessoas e entre elas algumas de reconhecida capacidade científica. Dos trabalhos que presenciei, ficou-me a mais dolorosa impressão; Deus me perdoe os falsos juízos que então formei 
da ilustre diretoria que dirigia os destinos da Sociedade. [...] foi-me aconselhado à leitura das obras do imortal Kardec. Pela leitura, despertou-se-me o desejo de verificar experimentalmente as teorias que ia bebendo, e comecei a freqüentar as sessões dos grupos e sociedades então existentes, onde gradativamente fui recebendo as provas mais robustas da manifestação dos que eu chamava mortos. ${ }^{52}$

Elias da Silva veio a se tornar membro ativo da Comissão Confraternizadora da Sociedade Acadêmica Deus, Cristo e Caridade e chegou a fundar o Grupo Espírita Menezes, nome dado em homenagem a Antônio Carlos de Mendonça Furtado de Menezes, que fora um dos diretores da Sociedade Acadêmica. Seu primeiro contato, mais cientificista, digamos, com o espiritismo levou-o a escrever primeiramente no frontispício do seu jornal: “Órgão Evolucionista”, e a dedicar o periódico “a Allan Kardec, fundador da Ciência Espírita”.

Pelas considerações que acabamos de fazer e que constituem a nossa profissão de fé, os nossos leitores, coevos e vindouros, ficam cientes de que, alumiados pela luz da Doutrina Espírita, somos evolucionistas essencialmente progressistas. ${ }^{53}$

\footnotetext{
${ }^{52}$ Reformador, $1^{\circ}$ de setembro de 1891.

${ }^{53}$ Editorial. Reformador, 21 de janeiro de 1883.
} 


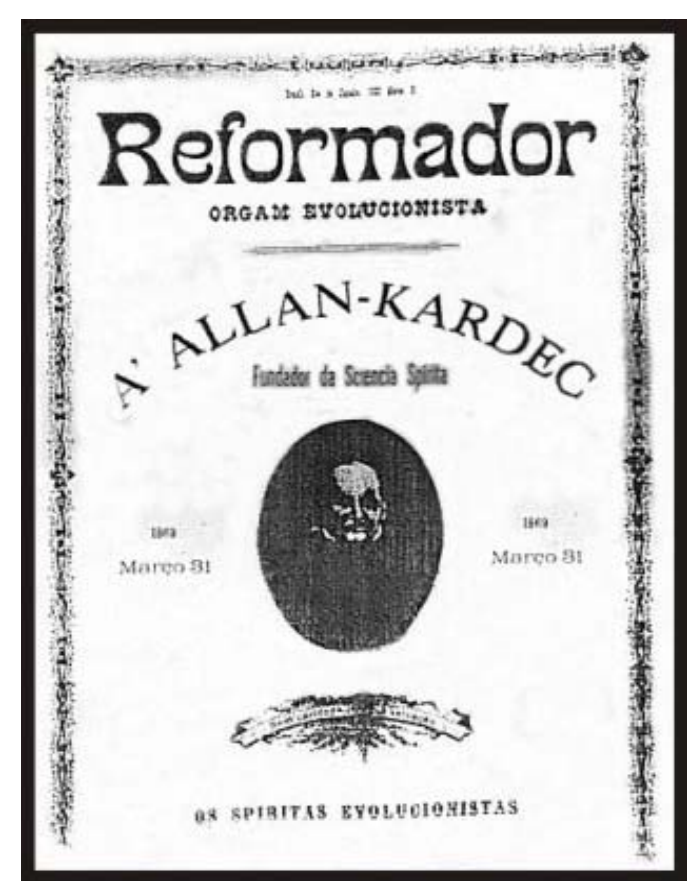

O Reformador-Orgam Evolucionista

Em 1884, com a então criação da FEB, O Reformador - agora em formato de revista - passou a ser o seu órgão oficial, contribuindo, e muito, no processo de legitimação e de delimitação do que veio a ser o espiritismo em terras brasileiras. Tempos depois, seu frontispício mudaria para "Revista de Espiritismo Cristão". Nela foram escritos inúmeros artigos em prol da unificação e do delineamento do espiritismo, este mesmo que hoje podemos dizer oficial, ou pelo menos o mais conhecido e difundido no Brasil. Mas além desse propósito, $O$ Reformador também surgia com o intuito de defender o espiritismo dos ataques discriminatórios feitos através de duas pastorais católicas, distribuídas pelo bispo do Rio de Janeiro ao Episcopado Brasileiro. A primeira foi a Pastoral da Diocese de São Sebastião do Rio de Janeiro, redigida por Dom Pedro Maria de Lacerda, datada de 15 de julho de 1881, na qual o prelado qualificava os espíritas de "possessos, dementes e alucinados". A ela respondeu também a Revista da Sociedade Acadêmica Deus, Cristo e Caridade, em vários números, a partir de agosto de 1881. A segunda Carta Pastoral, igualmente do mesmo prelado, com data de 15 de junho de 1882, tem o Antigo Testamento engenhosamente citado para contraditar as comunicações mediúnicas; e tão taxativo e enfático chegou a ser aquele prelado, que, 
referindo-se aos espíritas, registrava: "Devemos odiar por dever de consciência”. Daí os primeiros números do Reformador terem sido ocupados em boa parte com críticas a essas pastorais e com refutações a artigos escritos em $O$ Apóstolo, órgão católico bastante difundido à época. Dessa forma, apareciam nas páginas do Reformador as respostas contestatórias dos espíritas ao ataque católico:

A primeira parte da Pastoral, conquanto cheia de citações dos Evangelistas, não parece ser escrita sob a inspiração do espírito do Cristianismo, como era de se esperar do Ministro da Religião do Manso e Humilde [...]. A idéia dominante em toda a pastoral mostra claramente que foi o espírito do judaísmo que a bafejou, principalmente no parágrafo consagrado ao Espiritismo.

Tornar-se-ia por demais longo este artigo se passássemos agora a analisar ponto por ponto a primeira, a segunda e a terceira parte da Pastoral, que nós por amor do Bispado deveríamos qualificar ao menor de malfadada; por amor ao homem devemos denominar bendita - lembrados do Sermão da Montanha. E maior terá o seu mérito se por causa dela o digno Prelado Brasileiro for estudar a ciência espírita. ${ }^{54}$

Réplicas espíritas não ficaram sem tréplicas católicas. Foi escrita imediatamente uma série de artigos n’O Apóstolo, intitulada “O espiritismo”, em consecutivos números no ano de 1883. Principalmente contrários à idéia de reencarnação e à evocação dos mortos, o prelado repisava a sua posição e ressaltava que a Igreja também respeitava o "Século das Luzes” e a liberdade de consciência, bandeiras trazidas pelo espiritismo como forma de se distinguir dos demais sistemas de pensamento, principalmente dos sistemas religiosos. Aliás, era essa a postura mais válida naquela época, a de se enfileirar nos ideais iluministas e cientificistas, sobretudo o de progresso, posição mais legítima a tomar no momento, mesmo no campo religioso. E colocando tudo que é

${ }^{54}$ Reformador, 21 de janeiro de 1883. 
contrário à Igreja num só movimento, bem distinto e oposto a ela, escrevia o clero:

Todos os erros são os mesmos. Mudam somente o nome e se cobrem com a capa do progresso e da ciência. [...] E com outros muitos princípios errôneos, ímpios e contraditórios, pretende o espiritismo destruir todos os dogmas, insinuar-se e fazer prosélitos à moda de Maomé, descobrindo os mais largos horizontes de gozos e prazeres nessas sucessivas vidas [...]. Vamos ver no último quartel do XIX reviverem os prestígios da nigromancia, [...] ou então ser ensinada e propagada a metempsicose.

Amamos o progresso, procuramos as luzes e respeitamos a liberdade de consciência bem entendida, como a observa a Igreja, mas é nosso princípio: Diligile homines interficite errores.

Não tratamos de indivíduos. Discutimos princípios, e eis porque não nos toca o que nos dirigiu o Reformador. A caridade não consiste em ficar-se surdo ao ensino herético e considerar aceitável uma doutrina condenada, perversa e nociva à moral e à sociedade. ${ }^{55}$

Enquanto o embate simbólico se desenrolava, eram realizadas na FEB conferências públicas, ao todo vinte e três, sobre o espiritismo, nos anos de 1885, 1886, 1887, dadas por diretores e outras pessoas ligadas ou não a ela. Empreendimento de êxito, pelo menos era o que afirmava $O$ Reformador $^{56}$, essas conferências conseguiram atrair para o espiritismo um bom número de pessoas, tornando-se, por isso, uma via de acesso privilegiada à orquestração de concepções e orientações gerais compartilhadas pelos membros da FEB.

Por conta talvez dessa sua ligação com a Federação Espírita Brasileira, o que lhe garantiu respaldo institucional, $O$ Reformador não passaria por apuros como ocorreu com os demais periódicos da mesma época,

${ }^{55}$ O Apóstolo, 18 de março de 1883 (grifos do autor).

56 Reformador, 15 de agosto de 1886; Reformador, 15 de dezembro de 1887. Menciona-se que o número médio de participantes de cada conferência era de 500 pessoas. 
sobrevivendo, desta maneira, até os dias de hoje ${ }^{57}$. Assim, como porta-voz desta instituição e do espiritismo que aí vinha se formando, o órgão passou a mediar o seu programa espírita. Em questões políticas, alinhou-se abertamente, desde seus primórdios, como defensor da causa dos escravos negros do Brasil, isso porque boa parte dos espíritas desta instituição (mas não somente dela) era bastante atuante do movimento abolicionista ${ }^{58}$.

Tem-se a impressão de que a partir de então o espiritismo começava a tomar um rumo diferente do que fora em Salvador. O enfoque baiano alteravase. O espiritismo no Rio de Janeiro parecia identificar-se agora com uma realidade diferente, cujas aproximações com as questões republicanas e abolicionistas estavam mais evidentes, sobretudo se analisarmos as trajetórias de seus principais agentes. A discussão, doravante, enveredava-se por outros caminhos, rumo a uma formatação mais consistente do que viria a ser o espiritismo oficial aqui no Brasil. As condições sociais de vida da população urbana do Rio favoreciam a sua expansão, sobretudo a expansão de uma das facetas do espiritismo: a religiosa, ou melhor dizendo, a terapêutica-religiosa.

${ }^{57}$ Cronologicamente, o Reformador foi a décima folha espírita nascida no Brasil, como afirma Zêus Wantuil no artigo "Centenário do Reformador" (Reformador, dezembro de 1982). Já Clóvis Ramos afirma ser o oitavo (RAMOS, 1979, p. 5). Décimo ou oitavo, o que importa é que há muito se tornou o mais antigo periódico da imprensa espírita brasileira. Registram os "Anais da Biblioteca Nacional" (vol. 85) que o Reformador é um dos quatro periódicos nascidos no Rio de Janeiro, de 1808 a 1889, que sobreviveram até os dias de hoje.

${ }^{58}$ Encontramos um exemplo desse posicionamento nas ações engajadas de um dos espíritas mais conhecidos até os dias de hoje, o Dr. Adolfo Bezerra de Menezes, que publicou, em 1869, pela tipologia Progresso, um ensaio intitulado "A escravidão no Brasil e as medidas que convêm tomar para extingui-la sem dano para a nação". 


\section{Capítulo II - "Pelo fruto se conhece a árvore" ou o critério da escolha dos intelectuais}

\section{O "Allan Kardec brasileiro" e o que é Espiritismo}

É sabido que a condição política para a pluralidade religiosa no Brasil deu-se basicamente com a instauração de um Estado laico logo após a proclamação da República, nomeadamente com a Constituição aprovada em 1891. Diante desse quadro, vale à pena insistir nas modificações ocorridas na atuação e no discurso da Federação Espírita Brasileira, que logo se dimensionaram para fazer frente à nova situação político-institucional. Se antes da República os espíritas recebiam ataques constantes da imprensa, reclamações de médicos e mesmo acusações de charlatanismo (além dos ataques católicos, claro), foi somente a partir de 1890, com a aprovação do Código Penal ${ }^{59}$, que os espíritas passaram a sofrer judicialmente processos condenatórios $^{60}$. Fosse pela pressão do clero, ou fosse pela pressão dos positivistas, ou fosse ainda pela pressão da classe médica brasileira alopata, temerosa da disseminação sem controle do curandeirismo, os legisladores acabaram por elaborar o Código Penal de forma bastante singular. Nele havia a associação entre a prática do espiritismo e os rituais de magia e adivinhações. O texto dizia o seguinte:

Art. 157. Praticar o espiritismo, a magia e seus sortilégios, usar de talismãs e cartomancia, para despertar sentimento de ódio ou

${ }^{59}$ O Código Penal de 1890 estabelecia nos art. 156, 157, 158 punições às práticas mágicas, ao curandeirismo, ao charlatanismo e ao espiritismo. A validade desses artigos estendeu-se até a Constituição de 1964.

${ }^{60}$ O livro de Emerson Giumbelli (1997a) trata especificamente das acusações e dos processos judiciais que sofreram alguns espíritas cariocas entre os anos de 1890 e 1950. Outros trabalhos que têm o mesmo objeto são o de Yvonne Maggie (1992) e o de Ana Lúcia Pastore Schritzmeyer (2004). 
amor, inculcar curas de moléstias curáveis ou incuráveis, enfim, para fascinar e subjugar a credulidade pública.

Pena: de prisão cellular de 1 a 6 meses e multa de $100 \$ 000$ a $500 \$ 000[\ldots]^{61}$.

Além desse artigo, outros dois o complementavam quando o assunto era delimitar a ação curativa legal.

Art. 156. Exercer a medicina em qualquer de seus ramos, a arte dentária ou a pharmacia: praticar a homeophatia, a dosimetria, o hypnotismo ou magnetismo animal, sem estar habilitado segundo as leis e regulamentos.

Pena: de prisão cellular por um a seis meses, e multa de $100 \$ 00$ a $500 \$ 000[\ldots]$.

Art. 158. Ministrar ou simplesmente prescrever, como meio curativo, para uso interno ou externo, e sob qualquer forma preparada, substância de qualquer dos reinos da natureza, fazendo, ou exercendo, assim, o ofício do denominado curandeiro.

Pena: de prisão cellular por um a seis meses, e multa de $100 \$ 000$ a $500 \$ 000[\ldots]$

Por esse motivo, alguns espíritas se reuniram a fim de reivindicar mudanças no novo Código. Foram então reclamar com Campos Sales, Ministro da Justiça à época, empreitada que não rendeu frutos. O seu relator, João Batista Pinheiro, limitou-se a dizer que o texto referia-se à prática do "baixo" espiritismo, práticas que se relacionariam às crenças afro-brasileiras.

Mas, provavelmente, o que estaria ocorrendo naquele momento seria o enquadramento dos espíritas como causadores dos (“novos”) problemas que foram sendo encaixados no recém-criado rótulo Saúde Pública, desenvolvido com a instauração do regime republicano ${ }^{62}$, uma vez que alguns espíritas

${ }^{61}$ Grifos nossos.

${ }^{62}$ Foi criado em 1890 o Conselho de Saúde Pública e Inspetoria Geral de Higiene. Já havia desde o Império certa preocupação quanto à vigilância sanitária, sobretudo dos portos. 
arrogavam-se o direito de curar os males físicos e morais através da manipulação de “passes magnéticos” e de remédios homeopáticos. Isso ia também de encontro ao processo concomitante de autonomização dos poderes da esfera médica, que buscava, nesse mesmo momento, garantir legalmente o monopólio da cura. Ademais, os espíritas eram igualmente enquadrados nas leis penais por práticas de exploração da credulidade pública, algumas denunciadas, pois teriam tido fins lucrativos.

Isso tudo ocorria porque na recém-constituída República dos Estados Unidos do Brasil, especialmente na sua capital e nas grandes metrópoles, as primeiras décadas, sobretudo a de 1890-1900, podem ser vistas como um momento bastante específico da nossa história. Em diferentes níveis surgiam as preocupações de controlar, de conter, de mapear e de classificar, preocupações ligadas ao objetivo do governo de instituir uma nova ordem urbana, fator necessário para a realização do progresso. Além disso, esses processos eram o resultado do realçamento de uma também recente noção de público, que ajudou a promover a legalização da repressão àqueles cujas ações iam contra o seu conteúdo.

Mas por outro lado, o que também poderia estar ocorrendo seria a utilização dos espíritas - e nessa categoria entravam quaisquer opositores, adversários ou ameaçadores das crenças católicas - como “bodes expiatórios” para diminuir a oposição do catolicismo ao novo regime, causada pelo desatrelamento entre a Igreja e o Estado.

Na profusão dos processos de criminalização, em conseqüência do novo Código Penal, vários espíritas foram presos a partir de 1891, condenados por diversas práticas - “espíritas”, “mágicas”, “adivinhatórias” - em virtude de suas pretensões curandeirísticas representarem um perigo para a "saúde pública” e para a “credulidade pública”. Por conta dessas prisões e para evitar

Mas foi somente com a instauração da República que as noções de Vigilância Sanitária e Saúde Pública começaram a receber os primeiros contornos cuja conformação mais bem acabada conhecemos hoje. 
maiores confusões, muitos centros decidiram fechar temporariamente suas portas.

Fosse por conta das novas noções e referenciais republicanos, fosse por conta das recentes leis penais e sanitárias, fosse por conta da pressão do corpo médico em formação, ou fosse ainda por conta da contrariedade da Igreja, qualquer tipo de punição oposta às práticas espíritas são conseqüências de uma causa inicial. Noutras palavras, se a repressão às práticas espíritas foi um fato incontestável desse período, assim aconteceu porque essas mesmas práticas passaram antes por um processo de criação, de constituição e de acionamento, resultado das obras de agentes investidos nesse processo; e só depois vieram a ser classificadas, punidas, reprimidas ou limitadas pelo Estado. Ou seja, afirmar que as práticas espíritas, ou melhor, que o espiritismo só se constituiu a partir de constrangimentos e injunções externas a ele, fossem jurídicas, fossem médicas, fossem de qualquer outra ordem, é menosprezar todo um trabalho prático e intelectual realizado, sobretudo, por agentes especialmente interessados e particularmente envolvidos nesse processo. Mas também é bom deixar claro, por outro lado, que essas repressões influenciaram de uma maneira ou de outra a conformação do espiritismo a determinados moldes. Isto, contudo, num segundo momento desse processo de conformação. Em outros termos, se inicialmente as práticas espíritas precisaram existir e se organizar minimamente (primeiro momento) para posteriormente serem condenadas e/ou limitadas, só depois de sofrerem condenações e/ou limitações elas tiveram que se remodelar a fim de poderem existir (segundo momento). Aí sim, nesse segundo processo, podemos visualizar os diálogos entre espíritas e seus opositores não-religiosos, sem perdermos de vista, evidentemente, os diversos diálogos que já vinham ocorrendo, de um lado e internamente aos diferentes espiritismos, e, por outro lado, entre os espíritas e seus opositores religiosos.

Cabe salientar aqui que os estudos sobre a formação do espiritismo que privilegiaram a análise dos fatores de constrangimentos externos na sua 
constituição, ao ressaltarem sobretudo o campo da “saúde pública” e as discussões entre as diferentes esferas a respeito do espiritismo (esferas médica, jurídica, científica, jornalística entre outras), acabaram automaticamente deslocando para último plano uma análise relacional tanto entre os diversos espíritas e espiritismos quanto entre os embates internos ao campo religioso, embates que possuem suas próprias fundamentações legítimas e seus fundamentos teológicos; isto é, deixaram de lado uma análise do ponto de vista do especificamente religioso.

Este é o caso da obra de Emerson Giumbelli (1997a) que apesar de bem argumentada e bem trabalhada, deixa expressamente de lado uma análise interna das lutas religiosas ao privilegiar "uma investigação antropológica da definição, social e historicamente constituída, dos critérios segundo os quais algo pode ser considerado uma religião” (GIUMBELLI, 1997a, p. 29). Para ele, tal processo é “o resultado do confronto entre lógicas diferenciadas $e$ heterogêneas [lógicas dos campos jurídico, médico, jornalístico e científico], sob as quais se revelam 'sistemas de crenças' cuja especificidade se produz entre discordâncias, desencontros e disputas em torno de questões absolutamente fundamentais” (IDEM, p. 34). Seu objetivo foi, portanto, o de “apreender, em suas especificidades e em sua relativa autonomia, os diversos discursos que se teceram a propósito do espiritismo, reconhecendo neles dimensões essenciais para a definição do estatuto e dos destinos dos grupos e das práticas espíritas” (IDEM, p. 35).

Outra obra que trabalha com o recorte das práticas mágico-religiosascurativas enquadradas nas leis penais é a de Ana Lúcia Pastore Schritzmeyer (2004). Levantando as interpretações jurisprudenciais dessas práticas, a autora pretendeu analisá-las identificando seus principais pressupostos e os alcances de suas aplicações. Em sua pesquisa, pode-se perceber um duplo esforço: um voltado para a compreensão do saber dos “cientistas da lei” a respeito de curandeiros, charlatães, exploradores da credulidade pública e das vítimas, e outro, sobre como eles elaboravam leis, doutrinas, e aplicavam-nas a casos 
concretos de "normatização" de curas mágico-religiosas. A autora analisou também o modo como os juristas aplicaram o saber antropológico, sobretudo no início do século XX, para se validarem, argumentativa e decisoriamente, com maior legitimidade científica. Essa é mais uma obra que identifica o processo de demarcação das fronteiras das religiões consideradas mágicas, entre elas o espiritismo, percebendo-o somente como o resultado das disputas entre diferentes saberes e discursos.

Nesse mesmo caminho seguiu o trabalho antropológico de Yvonne Maggie (1992), que trata da legitimação das religiões não-católicas e no qual a autora também enfatiza os enfrentamentos entre saberes e doutrinas que com elas dialogaram. Para a autora, os mecanismos reguladores criados pelo Estado republicano não teriam conseguido extirpar as crenças e práticas de caráter mágico. Pelo contrário, teriam sido fundamentais para a sua preservação. Mediante análise de processos instaurados entre 1890 e 1945 no Rio de Janeiro, Maggie demonstra como cada denúncia motivou o envolvimento e a tomada de posição de diversos atores sociais: desde os próprios adeptos de práticas religiosas, passando por policiais, técnicos, advogados e juízes, até médicos, psiquiatras, cientistas sociais e jornalistas. A partir de seus respectivos campos institucionais, cada um desses personagens forjava seu discurso a respeito do espiritismo, da magia e da feitiçaria, e a sua junção constituía uma grande arena em que pessoas, práticas, saberes e doutrinas eram colocados em contato de forma hierarquizada ou hierarquizada em surdina, quando menos. Nesse sentido, a repressão não teria simplesmente agido contra os grupos religiosos, mas produzido as próprias fronteiras demarcadoras de suas identidades.

Apesar, porém, da importância desses achados, Yvonne Maggie, por trabalhar somente com elementos dos discursos científico, jurídico e jornalístico, não vislumbra a ação dos próprios integrantes dessas religiões na busca esforçada de sua organização, codificação e legitimação no campo religioso: tanto os diálogos entre os intelectuais de uma mesma religião quanto a disputa destes face às demais religiões presentes no campo e "em campo". As 
“fronteiras demarcadoras de suas identidades" teriam sido geradas apenas pela repressão estatal, que teria dado origem aos processos nos tribunais judiciários, sendo também resultado dos conflitos entre os diferentes saberes e doutrinas.

Parece, pois, que o processo específico de formação do campo religioso brasileiro com a inserção de novos segmentos religiosos teve menor importância nesses trabalhos, uma vez que foi apresentado neles sempre sujeito aos demais campos. Isso porque as lutas e disputas simbólicas e materiais internas a ele não foram postas à análise, principalmente enquanto retraduções dos debates externos. As tensões existentes e os conflitos emergentes no campo religioso quase nada foram considerados em suas mais diversas e específicas facetas. Isto posto, entendemos que essa "submissão" nunca é total quanto o faz crer esses trabalhos. Nada ilustra melhor - por que permite raciocinar a fortiori - o efeito de refração exercida pelo campo religioso, isto é, uma modificação da forma, da direção ou do sentido de uma coordenada externa quando passa pela interface deste campo, sendo nele retrabalhada. Pensando nesses termos, podemos finalizar dizendo que, apesar de naturezas diferentes, a legalidade externa que estava sendo desenvolvida e exercida, isto é, a legalidade jurídica, garantia e reforçava ainda mais a legalidade interna (nos termos de Weber), ou seja, o funcionamento e a própria autonomia do campo em questão. Quanto mais delimitavam externamente, mais internamente autônomo tornava-se o campo.

Logo depois, quando tudo parecia caminhar um pouco melhor para o espiritismo, eis que em 1893, com a Revolta da Armada contra o então presidente Marechal Floriano Peixoto, o governo acabou endurecendo ainda mais o regime. Nessa época, os espíritas apresentaram novo protesto ao Congresso Nacional contra o Código Penal, mas os esforços foram em vão. A comissão revisora do Código não atendeu as reivindicações dos espíritas e ratificou os pontos já colocados em 1890. Vitimado então por dificuldades externas, $O$ Reformador deixou de circular no último trimestre daquele ano. 
Mas apesar das investidas estatais adversas ao espiritismo, o jeito mesmo foi o de se utilizar deste Estado que, se opressor de um lado, de outro passava a disponibilizar mecanismos legítimos - através da sua mais nova Constituição - para a existência, pelo menos de uma das facetas, do espiritismo. Assim, ainda que com prerrogativas, ou seja, desde que não afetasse a "saúde e a credulidade públicas" e não se intrometesse no âmbito legal dos esculápios, o Estado republicano brasileiro a partir de 1891 tornou-se defensor legal da liberdade de culto, e sob esse preciso direito o espiritismo conseguiria passar a atuar lidimamente.

Por causa de tudo isso e por conta, é claro, da presença cada vez mais forte dos denominados religiosos na direção da FEB, ela acabou passando por uma reestruturação e uma reorientação no que se refere à sua atuação institucional, que por estratégia passou a enfatizar no espiritismo seu caráter especificamente religioso, conduta que acabaria modificando definitivamente a presença (e o modo de presença) do espiritismo no Brasil.

Dessa forma, se a FEB passou a assumir a função de representação aos olhos das agremiações espíritas e diante do poder judiciário - para defender espíritas das acusações penais -, ela só o fez por dois motivos: o primeiro diz respeito ao cabedal de forças e capital sociais que agregava na figura de seus membros - advogados, médicos, jornalistas; o segundo, porque ao ressaltar e re-apresentar seu caráter religioso, o espiritismo passava a atuar como religião, entronizando uma nova posição - uma nova opção - no campo religioso brasileiro, agora um pouco mais plural. Isso faria com que a FEB passasse a seguir cada vez mais a lógica e a as regras próprias do campo que elegeu para a atuação do seu espiritismo. Assim, ao escolher a via religiosa, o espiritismo conseguiu proteger-se e legitimar-se no Brasil, definitivamente.

Todavia, cabe ressaltar novamente que para além dos fatores externos existentes e expressivos, internamente ao espiritismo a ala religiosa ganhava cada vez mais força na disputa da primazia de dizer o que era (ou não) espiritismo, angariando deste modo mais vigor e mais autoridade para 
conseguir sua consagração. Foi nesse contexto que os líderes religiosos do espiritismo tiveram que articulá-lo e organizá-lo, fosse doutrinariamente (enquanto crença religiosa sistematizada), fosse burocraticamente, nos moldes formais de uma instituição religiosa. Esse processo de racionalização e formalização, conduzido em dois níveis de organização, teórico e institucional, parece ter sido sentido como um imperativo, em vista da legitimidade necessária para a consolidação da recém-assumida, ou melhor, autoreivindicada religião no campo religioso brasileiro. O trabalho religioso de sistematização e estruturação teve nos seus intelectuais a fonte principal de energia. Foram eles que "inventaram", isto é, pensaram e articularam o espiritismo em moldes puramente religiosos, e conseqüentemente em suas possibilidades de atuação.

Com isso, passamos a ter pela frente um Espiritismo - oficial definido e orientado conforme uma religião. No entanto, é importante não perdermos de vista que a presença concomitante de outros "espiritismos" era um fato inegável. Porém, as ações religiosas de seus intelectuais com tendências a serem cada vez mais puramente religiosas indicavam um processo de autonomização do campo em questão, passível de análise sociológica justamente por ter adquirido uma acrescida autonomia, uma legalidade própria, como diria Weber. O trabalho religioso propriamente dito de delimitação e de produção dos bens de salvação ficou então a cargo dos intelectuais, alguns já mencionados, outros a mencionar mais à frente.

Pode-se, pois, perceber que o início histórico da constituição do campo religioso brasileiro, tendencialmente concorrencial, teve no trabalho dos intelectuais religiosos de cada religião a sua força motriz, processo que não seria diferente entre os subgrupos de cada segmento religioso, como bem atesta o espiritismo recém-nascido.

O ideal da FEB de reunir os grupos no Rio de Janeiro e rediscutir as orientações doutrinárias comuns era sem dúvida antigo entre os espíritas dessa 
instituição ${ }^{63}$. Desde 1889 isso já vinha sendo pensado e discutido pelos integrantes da entidade chamada Centro Espírita do Brasil, cuja criação fora apoiada pelo então presidente da FEB, Dr. Adolfo Bezerra de Menezes. A resolução posta no parecer elaborado pelo Centro não poderia ser outra: era necessário unificar o método de trabalho. Assim, submetendo-se cada vez mais a um novo prisma estrutural, o espiritismo, através do trabalho de seus líderes e porta-vozes, deveria articular a formação de um núcleo centralizador juntamente com um processo de normatização doutrinária. Coube ao então cognominado "Allan Kardec brasileiro", o Dr. Adolfo Bezerra de Menezes, a tarefa de dar esse passo e inserir definitivamente o espiritismo no campo religioso brasileiro.

\section{As predisposições de Bezerra de Menezes}

Adolfo Bezerra de Menezes, cearense, nasceu em 1831 na antiga Freguesia do Riacho do Sangue, hoje Solonópole. Seu pai, o capitão das antigas milícias e tenente-coronel da Guarda Nacional, educara-o nos "mais rígidos princípios do dever e da honra, praticando fervorosamente a religião católica, apostólica, romana. O menino Adolfo foi, portanto, criado nesse clima de severa [...] religiosidade" (SOARES, 2006, p. 35).

Figura importante para a formação de Bezerra de Menezes, seu pai inspirou-o moralmente, quando, ao perder sua fortuna por tê-la emprestado a familiares e amigos, passou a contar com o estritamente necessário para manter a família, indo da abundância à privação, processo que seria realidade também na vida do filho anos mais tarde.

Em 1842, por motivos políticos, em conseqüência das perseguições feitas aos liberais, sua família acabou tendo que viajar para o Rio Grande do Norte, local onde Bezerra completou os estudos de latim. De volta ao Ceará em

\footnotetext{
63 Notamos a presença de propostas de "união" e "consagramento" nos números do
} Reformador, 01 de janeiro de 1885; Reformador, 15 de maio de 1887, por exemplo. 
1846, Bezerra termina o Liceu sob as vistas de seu irmão, o Dr. Manuel Soares da Silva Menezes, influente político no Ceará e verdadeiro líder católico em sua terra natal. Somente em 1851 Bezerra iria para o Rio de Janeiro estudar medicina.

Como todo moço do interior nordestino daquele período, levou consigo um catolicismo eivado de fatos popularescos relacionados a manifestações de almas penadas, um habitus religioso brasileiro repleto de crendices fantasmagóricas. Desde criança, Bezerra de Menezes ouvia narrativas de aparições de espíritos, de manifestações do demônio, de casas malassombradas, imprimindo no garoto estigmas de medo (ABREU, 1996a, p. 18). Certa vez, na freguesia onde nascera, Bezerra, aos nove anos de idade, conhecera uma moça vítima de uma “possessão”. Chamado o vigário da localidade, este compareceu a fim de lhe aplicar o exorcismo, que de nada adiantou. Resultado: tanto o padre quanto o juiz do local declararam solenemente à população que o diabo havia entrado no corpo daquela moça. $\mathrm{O}$ fato havia chamado tanto a atenção de Bezerra que deixaria nele marcas em seu modo de pensar, causando-lhe as primeiras dúvidas quanto à eficiência do catolicismo (ACQUARONE, 1980, p. 23).

Pode-se afirmar que Bezerra compartilhava de uma disposição religiosa duradoura, generalizada e transferível de pensar e de agir conforme os princípios de uma maneira subjetiva de ver e de entender o mundo. A essa disposição acrescia-se o costume de tomar mezinhas milagrosas receitadas geralmente por um feiticeiro ou por uma mucama. E ainda segundo essa disposição, acreditava-se na eficácia de plantas e talismãs mágicos para espantar mau-olhado, e em elixires, arrudas, beberagens e bruxedos para garantir saúde e vitalidade. Enfim, uma religiosidade (oficialmente católica) saturada de elementos mágicos que persistia em todas as camadas sociais; uma salada mística de crenças, folclore e dogmas católicos.

Mas agora no Rio de Janeiro, contava ele mesmo: 
Continuei na crença e práticas religiosas, que eu trouxe do berço; mas na convivência com os moços, meus colegas, em sua maior parte, livres pensadores: ateus, comecei batendo-me com eles - e acabei concorde com eles, parecendo-me excelso não ter a gente que prestar contas de seus atos. Não foi difícil esta mudança, pela razão de não ser firmada em fé raciocinada a minha crença católica; mas, apesar disso, a mudança não foi radical, porque nunca pude banir de todo a crença em Deus e na alma. ${ }^{64}$

Entre as crenças que mantinha e a razão que o orientava em outro sentido, Bezerra relatava:

[...] não encontrava onde assentar minha crença, porque o ensino de Jesus - que uma força intrínseca, uma disposição psíquica me levaram a procurar, como o nauta perdido na vastidão dos mares procura o Norte - me era oferecido sob um aspecto impossível de acomodar-se com um sentido íntimo, intuitivo, exato, que me desse a razão e a consciência de ali estar a verdade; mas a verdade não é aquilo.

Ah! a Igreja Romana! a Igreja Romana!

O Cristianismo nunca terá tão formidável inimigo! $O$ materialismo nunca terá aliado tão prestimoso! ${ }^{65}$

O novo entorno social no qual Bezerra de Menezes passava agora a se situar, isto é, o Rio de Janeiro, não poderia deixar de orientá-lo em algum sentido. Assim, imbuído de ideais racionalistas, dispostos em sua trajetória pela sua formação de médico cientista, retraduzidos agora para a esfera religiosa, afirmava que “[...] sentia a necessidade de crer não nessa crença imposta à fé, mas numa crença firmada na razão e na consciência” ${ }^{66}$.

${ }^{64}$ MENEZES, Bezerra de. Evolução religiosa de Bezerra de Menezes. Reformador, 15 de outubro de 1892.

${ }^{65}$ IDEM.

${ }^{66}$ IDEM, grifos nossos. 
Não foi tão-somente a tradução de algumas das obras kardequianas a importante contribuição que Dr. Joaquim Carlos Travassos trouxe ao espiritismo nascente no Brasil. A ele deveu-se também a apresentação da doutrina espírita a Bezerra de Menezes.

Um colega, porém, tendo traduzido “O Livro dos Espíritos”, de Allan Kardec, fez-me presente de um exemplar, que aceitei, por cortesia. Deu-mo na cidade, e eu morava na Tijuca, a uma hora de viagem de bonde. Embarquei com o livro e, não tendo distração para a longa e fastidiosa viagem, disse comigo: ora, adeus! Não hei de ir para o inferno por ler isto; e, depois, é ridículo confessar-me ignorante de uma filosofia, quando tenho estudado todas as escolas filosóficas. ${ }^{67}$

Entendido em princípio como filosofia, mas também visto como possível obra do diabo - visão de mundo extremamente catolicizada por conta ainda de sua formação religiosa -, o espiritismo para Bezerra de Menezes tomou definitivamente novas feições assim que ele terminou a leitura do livro de Allan Kardec, numa espécie de encontro miraculoso entre as suas disposições e a cosmologia espírita.

Lia; mas não encontrava nada que fosse novo para meu espírito, e entretanto tudo aquilo era novo para mim! [...] parecia que eu era espírita inconsciente, ou, como se diz vulgarmente, de nascença. ${ }^{68}$

Mas não foi somente a "razão" que levou o médico a aderir ao espiritismo. Outros fatores, dentre eles o próprio descontentamento com a medicina alopata, fizeram com que Bezerra voltasse os olhos ao espiritismo e à medicina homeopata, cuja introdução no Brasil esteve intimamente ligada ao espiritismo $^{69}$. Certa feita, teriam sido os "efeitos terapêuticos" tanto do

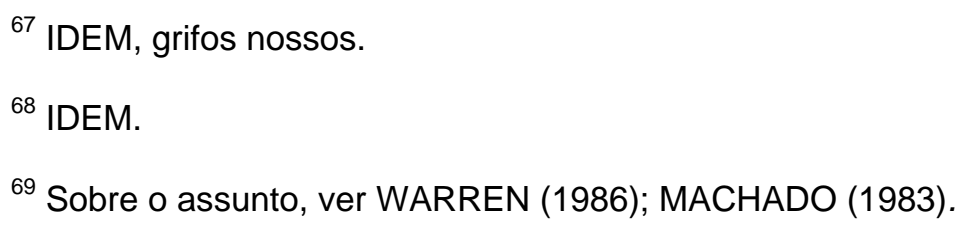


espiritismo quanto da homeopatia que conseguiram curá-lo após ter sofrido mais de cinco anos com dispepsia sem solução médica, e fizeram curar também sua segunda esposa, diagnosticada com câncer, mas que, segundo um médium, sofria apenas de problemas de ordem ginecológica de fácil resolução.

Por toda a sua vivência com a religiosidade católica, mas também por conta de sua formação médico-racionalista, Bezerra pôde enxergar o espiritismo sob dois prismas. Encarou-o como portador de uma moral cristã que não é imposta "por força de uma autoridade que se arroga o direito de impor a fé" (SOUZA, 2001, p. 33), e também lhe conferiu todas as credenciais de uma ciência positiva ${ }^{70}$, ao afirmar que “o espiritismo é para mim uma ciência, cujos postulados são demonstrados tão perfeitamente como se demonstra o peso de um corpo" (SOARES, 2006, p. 62).

Entretanto, foi ao aspecto moral e religioso que Bezerra mais se apegou, talvez porque Kardec propusesse uma fé raciocinada, ou talvez pela influência dos modelos de conduta de seu pai e de seu irmão, ambos extremamente religiosos, duas figuras importantes em sua vida: "ao demais, eu considerava sagrado tudo o que meus pais me ensinavam a crer e a praticar [...]" (IDEM, p. 55); “[...] uma impressão que deixou em minha alma o ensino paterno” ${ }^{71}$; ou mesmo talvez pelo fato de compreender que somente enquanto religião o espiritismo teria uma via de legitimação mais fácil e certamente mais segura a seguir. E são exatamente os seus próprios trabalhos de conversão do espiritismo em religião que melhor enfatizam essa última suposição.

Imprescindível é notar que Bezerra de Menezes foi um dos líderes e intelectuais mais importantes que trabalharam para a consolidação da doutrina

${ }^{70}$ Sua obra, A loucura sob novo prisma, com o subtítulo "estudo psíquico-fisiológico", é uma clara alusão a sua expectativa de estar contribuindo para a definição dos rumos da ciência psiquiátrica segundo o espiritismo.

71 Conferência organizada pela Federação Espírita Brasileira, pronunciada por Bezerra de Menezes em 6 de agosto de 1886 e reproduzida no Reformador, 15 de setembro de 1886. 
espírita nos moldes ensejados pelo campo religioso brasileiro então em formação. Não é à toa que foi e ainda é reconhecido pela designação de "Allan Kardec brasileiro", justamente pelo fato de ter sido ele o "codificador" do espiritismo no Brasil, o seu organizador. A partir daí, a idéia de uma "doutrina religiosa” - enquanto corpo sistemático e organizado de princípios - só se tornou possível através de sua interpretação. Coube a Bezerra não só o trabalho de selecionar, na obra de Allan Kardec, determinados aspectos em detrimento de outros, como também o de encadeá-los, juntamente com outras coordenadas externas à obra kardequiana, visando dar ao seu espiritismo certa coerência e ordenação dentro de uma nova conformação estrutural.

Por conta de toda a sua trajetória podemos afirmar que quando Bezerra de Menezes decidiu entrar no jogo, os seus lances, como os de todos os demais que assim o procedem ou procederam, já estavam mais ou menos dados, mais ou menos feitos. Primeiramente, porque ele já partilhava da doxa, ou seja, da fé (especificamente católica) em Deus e na existência de espíritos ou de fantasmas manipuladores de objetos e de pessoas, bem como na eficácia de elixires, mezinhas etc. Em segundo lugar, porque quando começou a se envolver na illusio, ou seja, quando começou a despender esforços, a investir mais pesadamente no jogo, suas tomadas de posição já se mostravam mais ou menos pré-demarcadas, pois carregavam o peso do cabedal angariado ao longo de sua trajetória educacional e social. Foram, portanto, as suas predisposições que favoreceram, como veremos mais adiante, a formação de um espiritismo religioso-terapêutico, preocupado com a cura, fosse da alma, fosse do corpo (herança de sua formação médica), sobretudo através de tratamentos homeopáticos e de "águas fluidificadas" - equivalentes espíritas para as tais mesinhas e elixires. 


\section{Sai de cena o homem político; entra o "Apóstolo" do espiritismo}

Em 1858 Bezerra de Menezes se candidatou a uma vaga de substituto da Secção de Cirurgia da Faculdade de Medicina. Antes que tal ocorresse, por intercessão de seu mestre Manoel Feliciano Pereira de Carvalho, então Cirurgião-Mor do Exército, foi nomeado seu assistente, no posto de CirurgiãoTenente.

Anos mais tarde, em 1860, Bezerra colocaria seu nome na "lista de candidatos à vereança”, organizada pelo Partido Liberal, decisão influenciada pelas idéias herdadas de seu pai. Foi eleito vereador, em 1861, mas teve sua eleição impugnada pelo chefe da Câmara, o conservador Dr. Haddock Lobo, sob a alegação de ser médico militar. Objetivando servir ao seu partido, que necessitava dele a fim de obter maioria na Câmara, Bezerra de Menezes resolveu afastar-se do Exército. Por seu trabalho político, o Partido Liberal the deu uma votação estrondosa em 1864, reelegendo-o apesar do combate promovido pelos adversários e por alguns chefes superiores de seu próprio partido. Com isso, a sua popularidade crescia, crescendo também o seu prestígio e todas as suas redes de relacionamento, o que lhe propiciou ser eleito, em 1867, ao cargo de Deputado Geral pelo distrito da Corte. Seus capitais simbólico, social e político eram cada vez maiores. Se na Câmara Municipal o Dr. Bezerra de Menezes conquistara fama de inteligente, ilustrado, ativo e honesto (SOARES, 2006, p. 47), embora atacado pelos inimigos que criava por não contemporizar com certas pretensões, na Câmara dos Deputados tornou seu nome conhecido por todo país.

Após a ascensão ao poder do Partido Conservador, a Câmara foi dissolvida. Durante dez anos de domínio conservador, Bezerra não deixara de trabalhar, quer nos comícios, quer na imprensa, tendo sido um dos redatores da Reforma, órgão liberal da Corte.

Então desviado das atividades políticas no governo, passou a se dedicar ao desenvolvimento de empreendimentos empresariais; criou a Companhia de 
Estrada de Ferro Macaé-Campos, na então província do Rio de Janeiro. Depois, empenhou-se na construção da via férrea de Sto. Antônio de Pádua, etapa necessária ao seu desejo, não concretizado, de levá-la até o Rio Doce. Foi um dos diretores da Companhia Arquitetônica que, em 1872, abriu o "Boulevard 28 de Setembro" no então bairro de Vila Isabel, e também presidente da Companhia Carril de S. Cristóvão, em 1875.

Retornando à política em 1867, exerce o cargo de vereador até 1880, ano de sua eleição a Deputado Geral pela Província do Rio de Janeiro, último cargo governamental de Bezerra de Menezes, encerrando assim e definitivamente suas atividades políticas.

Traquejado no relacionamento com pessoas das camadas mais privilegiadas da sociedade carioca, Bezerra não só angariou prestígio como também soube utilizar-se dele para a sua “missão” espírita. Sua filiação oficial ao espiritismo foi como uma transfusão de sangue para o movimento, que dali em diante passou a pulsar em ritmo mais acelerado, agora com mais respaldo social. Assim, em 1886, numa das reuniões espíritas costumeiras que se realizavam no grande Salão da Guarda Velha, local freqüentado pela elite social, o cidadão Bezerra de Menezes, eminente político, médico, dono de certa fortuna e até aquele momento católico, proclamava publicamente sua decisiva conversão ao espiritismo ${ }^{72}$.

Sua pena começou a trabalhar em 1886, quando assinou o primeiro artigo a serviço do caráter religioso do espiritismo. Todos os domingos em $O$ Paiz, tradicional órgão da imprensa brasileira, Max, pseudônimo de Bezerra de Menezes, demonstrava sua capacidade literária no terreno filosófico e religioso - capacidade disposta em sua trajetória por sua formação. Na série denominada "Estudos Filosóficos”, sob o título “O Espiritismo”, Max “codificava” a doutrina ao mesmo tempo em que respondia à reação católica desencadeada pelo jornal $O$ Apóstolo. Suas ligações sociais também foram importantes nesse sentido. Não foi à toa que o Senador Quintino Bocaiúva,

\footnotetext{
${ }^{72}$ Segundo Soares (2006, p. 77), havia naquela reunião cerca de duas mil pessoas.
} 
chefe-redator d'O Paiz, jornal de grande penetração e circulação, talvez o mais lido do Brasil, cedera espaço para Max publicar seus artigos. Bezerra de Menezes e Quintino eram amigos e ambos compartilhavam das mesmas idéias liberais, sobretudo a tolerância religiosa e os ideais abolicionistas e republicanos.

Aliás, o espiritismo, através de seus portadores, foi introduzido no Brasil em um momento em que várias outras correntes de pensamento originárias sobretudo da França, mas também da Europa como um todo, invadiam a intelectualidade nacional, imprimindo os caracteres do nosso "iluminismo brasileiro" (Cf. BARROS, 1959). Nesse momento, duas vertentes, além de uma terceira fundamentalmente católica, configuravam o panorama intelectual: uma liberal, associada à afirmação do princípio da liberdade humana e das bandeiras políticas do abolicionismo e do republicanismo; outra cientificista, entretida com a leitura de manuais de positivismo e de evolucionismo. Assim, os partidários do espiritismo, formados sob o influxo de ideais estrangeiros, entretinham relações com personagens (conterrâneos ou não) e com saberes associados a cada uma dessas correntes, muitas vezes participando ativamente desses movimentos no Brasil. Foi deste modo que, entrelaçando idéias européias ao nosso contexto sócio-político, codificavam à brasileira não só as correntes de pensamento importadas da Europa como também o próprio espiritismo francês. Os espíritas identificavam-se, pois, com as causas abolicionistas e republicanas, e se contrapunham a alguns preceitos católicos. Importantes líderes do espiritismo, como o próprio Bezerra de Menezes, além de Joaquim Travassos, Bittencourt Sampaio e Silva Neto, expressaram suas visões totalmente contrárias à escravidão em escritos próprios, e vários outros colaboraram diretamente com clubes abolicionistas. Os dois últimos chegaram mesmo a ser signatários do Manifesto Republicano de $1870^{73}$.

${ }^{73}$ Sobre associação do espiritismo com o republicanismo e com o abolicionismo, ver Damazio (1994). Sobre as relações entre maçonaria e espiritismo, ver Machado (1983, p. 129-145). 
De novembro de 1886 a dezembro de 1893, isto é, durante sete anos Bezerra de Menezes escreveu sua coluna ininterruptamente. Seus trabalhos, seu capital simbólico e suas ligações institucionais contribuíram decisivamente para a "codificação" da doutrina, marcando uma nova fase da propaganda e expansão do espiritismo no Brasil.

Para além desses artigos, outro trabalho que rendeu muitos frutos para a formatação do espiritismo foi o diálogo religioso que estabeleceu com o próprio irmão, Manuel Soares da Silva Menezes, católico fervoroso. A partir desse diálogo, Bezerra escreveu a sua primeira obra mais bem estruturada no campo da divulgação do espiritismo, A Doutrina Espírita como Filosofia Teogônica, mais tarde reeditada levando o título mais explícito mostrando a que veio: Uma carta de Bezerra de Menezes. Nessa “epístola” de cerca de 100 páginas dirigida a seu irmão, Bezerra demonstrou toda a sua erudição, verdadeira aula de história comparada das religiões. Fez igualmente citações de pensamentos de filósofos; entre outros, citou Pitágoras, Sócrates, Platão e Santo Agostinho, tudo para mostrar que as idéias e pressupostos espíritas, tais como a reencarnação, já haviam sido aceitos desde a Antiguidade por vultos de alto gabarito. Sua argumentação girou em torno da divisa: o espiritismo não era outra coisa senão a própria “continuação da história do pensamento filosófico e do conhecimento humano, bem como da moral de Cristo, a mesma pregada pela Igreja, mas deturpada ao longo de sua história”.

A partir da leitura desta carta-ensaio, pode-se afirmar que Bezerra de Menezes não viera trazer a espada e sim a paz. Sua visão de espiritismo era parecida, mas não idêntica, com a de Telles de Menezes, o que equivale a dizer que, embora não concordasse com alguns pontos pregados pela igreja católica, o espiritismo não era de todo contrário ou totalmente diferente do catolicismo, posto ser igualmente cristão; não havia, portanto, a necessidade de confronto “armado”, já que a maior parte do sistema de crenças entre os adversários era compatível. 
A nova revelação [o espiritismo] não altera a moral da Igreja, que todo mundo acata, não altera a Teodicéia da Igreja que só meia dúzia de infelizes repele - e isso por causa da tal história do inferno e penas eternas; mas altera exatamente o que o fanatismo abraçou: os dogmas da vida única com as penas eternas. (BEZERRA, 1963, p. 96)

A carta servia também para que ele pudesse se defender e afirmar que não era nem herege nem louco, em resposta aos ataques do irmão e por extensão de outros católicos.

Se eu não fosse cristão - e cristão convencido, pensa você que haveria consideração que me fizesse suportar as calúnias injuriosas de que tenho sido vítima?! (IDEM, p. 12)

Nela encontramos a sua definição de espiritismo em relação à doutrina católica, berço de sua religiosidade, com a qual Bezerra de Menezes inevitavelmente dialogou:

Que vale mais? Não ir à missa nem confessar-se e cuidar de corrigir, trabalhando dia e noite, as ruins inclinações de seu espírito ou ir todos os dias à missa, confessar-se todas as semanas - e deitarse em maus pensamentos - e dar largas ao descomedimento da língua - e irritar-se pelas ofensas ao ponto de procurar vingar-se - e pagar mal por mal - e, finalmente, não cuidar de afeiçoar a alma à pura moral de Jesus Cristo? (IDEM, p. 16)

Dessa maneira, Bezerra de Menezes expunha sua tese doutrinária, estabelecendo o confronto entre cristianismo e catolicismo, atando de vez o espiritismo ao cristianismo, como se fosse sua continuação "natural", só que mais evoluída, condizente aos tempos modernos. Elucida temas como: pluralidade das existências, imortalidade da alma, purgatório, inferno, céu, livre-arbítrio e reencarnação. É uma verdadeira profissão de fé espírita. Nela, bem como na série de artigos “Estudos Filosóficos”, a preocupação constante não é somente a de formular e articular um espiritismo religioso, mas também a de lhe dar uma legitimidade calcada na tradição histórico-filosófico-religiosa. É 
por isso que ele enfatiza temas pertencentes à filosofia, e vai buscar na história do cristianismo primitivo a origem da própria história do espiritismo. Mas há algo específico nesta carta e que nos seus demais escritos não aparece tão nitidamente: a questão da diferença entre metempsicose e reencarnação, diferença essa fundamental na visão de Bezerra para a compreensão do espiritismo, reencarnacionista por princípio.

Seu irmão insistia em afirmar que o espiritismo estava calcado na concepção da metempsicose, o que foi prontamente rechaçado por Bezerra. Confundir metempsicose com a noção de "pluralidade das existências" era para ele o mesmo que contrariar frontalmente e fazer oscilar a viga mestra do arcabouço espírita. A crença na sucessão das vidas estava para Bezerra estreitamente ligada à idéia de progresso e de evolução humana - divisas bem em voga à época. Menosprezá-la seria o equivalente a questionar e até mesmo impugnar toda a teoria espírita. Foi por isso que Bezerra de Menezes se dedicou a escrever longas linhas sobre o assunto. Assim, no início, partindo da negação das posições do irmão (ou da posição católica), Bezerra foi construindo o seu espiritismo, apenas ceifando os "erros" das interpretações alheias, fossem as católicas ou fossem mesmo as dos concorrentes internos ao próprio movimento espírita.

$V$. revela não conhecer os princípios fundamentais do Espiritismo, dizendo que são os de Pitágoras, que, como se sabe, foram colhidos no Egito e abraçados por Platão.

A metempsicose, tanto no reino dos Faraós, como na Grécia, consistia na transmigração das almas do corpo humano para corpos de animais irracionais, voltando à primitiva forma depois de três mil anos, segundo os Egípcios, e de mil anos, segundo Platão.

O Espiritismo não admite transmigração; estabelece a pluralidade das existências, mas todas com o puro caráter humano. $O$ espírito é criado para a perfeição, pelo saber e pela virtude, e marcha o seu destino através dos séculos, progredindo no duplo sentido, mediante múltiplas encarnações, até chegar ao estado de pureza 
exigida para poder entrar na sociedade de Deus, que é o destino humano, segundo a Igreja [...].

Também não é Espiritismo, como diz V., filho do politeísmo, religião dos demônios, que Jesus-Cristo expulsou. O Espiritismo não reconhece senão o Deus dos Cristãos - o Eterno Jeová, a quem rende o mais submisso culto e a quem invoca, pelas preces da Igreja, assim como ao Cristo, que toma por modelo todo o seu ensino [...].

Eu lhe afirmo que a moral espírita é a pura moral cristã: amor e caridade.

Eu lhe afirmo que a verdadeira Teodicéia espírita não difere, numa linha, da Teodicéia ortodoxa. E digo a verdadeira, porque a doutrina tem discípulos, como os tem a Igreja. (IDEM, p. 15-16, grifos do autor)

Sua preocupação, porém, ia mais longe que o simples esclarecimento de seu irmão sobre suas novas crenças e suas relações com o catolicismo. Sua intenção era mesmo chegar às origens do espiritismo, ou, nas suas palavras, às origens da “doutrina das múltiplas vidas” (IDEM, p. 17). Assim, ele foi determinando sistematicamente o que era e o que não era espiritismo, ao passo que lhe forjava legitimidade através da apropriação da história do pensamento filosófico-religioso.

A idéia básica desta doutrina, a pluralidade de existências, não é nova, como disse V., embora aplicando mal a metempsicose. Ela vem da origem dos tempos históricos, como a caridade, que serve de característica à doutrina de Jesus-Cristo. O que se deu com uma e com a outra foi que um dia passaram de concepções intuitivas da Humanidade à ordem de princípios definidos e de elementos integrantes de um sistema teogônico, apresentado ao mundo como verdade descida do Céu. (IDEM)

Bezerra de Menezes não mediu esforços na procura de fundamentos para a sua interpretação. Foi buscar em diversas fontes sua sustentação, uma base sólida tanto para a história do espiritismo quanto para a crença nas várias 
existências. Desde os Vedas, livro sagrado dos hindus, e o Bhagavad Gitá, percorrendo pelo budismo, bramanismo, mazdrismo, druidismo; desde as histórias dos egípcios, narrada por Heródoto, até às dos gregos e romanos, passando por Pitágoras, Virgílio, Plotino, Porfírio, Jâmblio e Platão; desde a teologia hebraica, de Zohar a Simão-Bem-Jachai, transitando pela Filosofia Cabalística, até o Antigo Testamento, citando Isaías, Jeremias e a Gênese; Bezerra chega finalmente ao Novo Testamento e aos Evangelhos, enfatizando, sobretudo, passagens que insinuam a existência da pluralidade das vidas. Dentre elas estão as que dizem que João Batista foi Elias, e a de Nicodemos, doutor da lei entre os israelitas, quando indaga a Jesus a respeito do significado da expressão “nascer de novo”.

Eis, para não continuar com citações, a origem do Espiritismo, ou da idéia em que ele assenta. Uma idéia, que vem do princípio do mundo, que encarna em todo o movimento civilizador dos povos, que prossegue através dos séculos sem se perder; uma idéia, que passa de geração a geração, de povo a povo, de raça a raça e, nestes tempos de luz, acende o facho das maiores inteligências do mundo; uma idéia que apresenta esses atestados, não pode ser repelida sem estudo, sem exame, sem repetidas experiências, senão pelos fanáticos e pelos possessos. (IDEM, p. 59)

Entretanto, seria um outro argumento melhor trabalhado e melhor desenvolvido que faria o papel, tão necessário, da legitimação de espiritismo enquanto religião cristã: a idéia de que o espiritismo era a Terceira Revelação de Deus.

O movimento de “codificação", postulado como necessário ao espiritismo em sua pretensão de doutrina religiosa, apresentava um caráter problemático. Quando olhamos para os mecanismos que legitimaram o cristianismo, pelo menos o papel regulador da igreja católica, vemos que a passagem de Jesus pela Terra é o signo da presença de Deus na história, presença que fora atestada no próprio dogma da divindade de Jesus Cristo. À igreja coube então a tarefa de continuar a obra de Cristo em duas dimensões, 
quais sejam, a institucional e a civilizatória. Ela passaria a ser o elo entre a Terra e o Céu, contendo em si algo de divino. Portanto, é nessa condição que a igreja sempre se legitimou como intérprete autorizada da vida de Jesus e conseqüentemente da palavra de Deus. Já no espiritismo, tal como concebido por Allan Kardec, a idéia de Cristo enquanto uma divindade na Terra é absolutamente repudiada. Jesus não teria se manifestado corporalmente na história enquanto uma divindade e sim enquanto um espírito humano extremamente elevado em termos morais. Isto, notar bem, para os kardecistas, já que esse era o exato ponto de celeuma e de discórdia entre eles e os denominados roustainguistas. O ponto mais candente das teses de J.-B. Roustaing asseverava que Jesus não nascera pela carne, mas que viera desempenhar sua missão revestido de um “corpo fluídico”, porém tangível. Segundo essa teoria, a gravidez e o parto de Maria fugiram às leis que regulam tais fatos. Em sua mensagem, o anjo Gabriel lhe explicara sua incumbência extraordinária sem esclarecer detalhes. A partir de então, o ventre de Maria começou a estufar e ela se acreditou fecundada. Mas tudo não passava de uma encenação montada pelos espíritos para manter as aparências. Durante nove meses Maria sentiu os sintomas de uma gravidez qualquer. Na hora do parto encontrava-se sozinha. "Magnetizada” pelos espíritos, ela teve uma vertigem e perdeu os sentidos. Ao despertar, encontrou ao seu lado um recém-nascido. Eis um relato espírita de lavra roustainguista.

Mas a despeito das divergências entre kardecistas e roustainguistas (ambos os segmentos tidos como religiosos dentro do espiritismo), o fato é que, ao contrário da doutrina católica, o espiritismo supõe uma fratura irreparável entre a “revelação” e a “codificação”. Dessa forma, desde o princípio o espiritismo não teve o mesmo grau de legitimidade e não desfrutou do mesmo estatuto de religião revelada e unificada como o catolicismo. Isso ajuda a entender por que as idéias de “uniformização” doutrinal e “unificação” entre os diversos subgrupos foram tão recorrentes por aqui, posto serem necessárias para a sua consolidação enquanto instituição religiosa; e tão complicadas, porque contava com diversas divergências. 
Essa era uma verdade, vale dizer, uma alegação já bastante legítima que a própria igreja católica soube bem utilizar para diminuir a importância, ou melhor, para deslegitimar qualquer tentativa por parte dos espíritas de formarem uma nova religião; era uma arma um tanto quanto significativa do ponto de vista da argumentação católica na busca da manutenção de seu monopólio religioso.

Já estamos no tempo de instituir-se uma religião como qualquer sociedade de recreio: é só fazerem-se os estatutos, nomear-se o chefe, e toca a casar e batizar e exercer todos os atos de religião! É já progresso, e muito tem andado a humanidade com o auxílio do espiritismo.

É o que aconselha um espírita no penúltimo Reformador, com toda convicção de suas santas idéias, porém com pasmo geral do bom senso!

Conquanto tenhamos muito em consideração o grau de ilustração dos que abraçam o espiritismo, contudo não podemos deixar de confessar que interpretam mal ou não querem compreender o sentido da palavra religião; pois que só desse modo poderão os espíritas ter a pretensão de fundar uma religião!

A palavra religião significar ligar. E geralmente adotada esta significação, faz nascer a idéia de um acordo recíproco entre Deus e o homem, tornando claro o verdadeiro caráter da religião, o único que conduz a uma concepção exata da idéia expressa pela palavra e do laço misterioso, que une o homem à Divindade.

E religião nunca foi obra do homem, mas de Deus, e de Deus tão somente. Religião, diz Santo Agostinho: é o vínculo que une o homem a Deus.

Ora, se religião é esse laço de união entre o homem e a Divindade, instituído pelo próprio Deus, como é que o espiritismo pretende fundar e estabelecer uma religião? 
Com que Deus unem os espíritas? A que Deus obedecem? Qual seu dogma, sua moral, seu sacrifício e seu sacerdócio?

[...] Só pode haver uma religião verdadeira, e esta é a que foi revelada por Deus, confirmada e aperfeiçoada por Jesus Cristo, que para isto morreu crucificado, e a que é ensinada pela Igreja. ${ }^{74}$

Porém, mal sabiam os católicos que o espiritismo também iria ter os seus próprios argumentos cosmogônicos e teológicos de validação para atuar no campo religioso; que também iria formar “sacerdotes” e que também iria criar seus próprios dogmas e eleger uma moral a seguir. Isso tudo era só uma questão de tempo. E nesse sentido, o que passaria, portanto, a entrar definitivamente no jogo para efetivar a sua legitimação seria o papel do intelectual espírita como portador pessoal de sua verdade religiosa. Ele deveria trabalhar arduamente para conquistar reconhecimento ao espiritismo. E como já dito anteriormente, dois fatores nesse sentido são extremamente importantes para a análise desse processo: de um lado, saber identificar quais foram os indivíduos que fizeram isso, aglutinando quais tipos de forças e em que contexto o fizeram; e, de outro, averiguar o nível de legitimidade que alcançaram.

Portanto, sob essas condições, a igreja sempre se legitimou como mediadora da palavra de Deus, função que teria sido outorgada diretamente por Jesus. Bem diferente ocorreu na história do espiritismo e dos seus mecanismos de legitimação. Ainda que ele clamasse para si o direito, o condão de ser cristão, a distância que se tem entre a presença de Jesus na Terra e a codificação do espiritismo é um tanto quanto extensa; são quase dois mil anos. Dessa forma, o mesmo argumento da igreja católica não cabia ao caso espírita. Então, como afirmar que o espiritismo é a própria continuação do cristianismo? Como reivindicar a legitimidade necessária para dizer-se religião, e mais que isso, uma religião cristã? Como, por fim, diminuir a distância entre a “revelação” e a “codificação”?

\footnotetext{
${ }^{74}$ O Apóstolo, 18 de maio de 1883 (grifos do autor).
} 
Houve, pois, muito trabalho religioso nesse sentido, e os esforços dirigidos para se responder a essas questões não seriam, ou melhor, não foram em vão. Muito pelo contrário, já que numa nação tradicionalmente católica cristã, o único espiritismo que poderia mesmo vingar seria o espiritismo religioso cristão. A melhor propaganda e a melhor fundamentação deveriam ser então calcadas no cristianismo. Assim, apoiado no Evangelho e na moral da caridade, a legitimação do espiritismo promovida por Bezerra de Menezes e por seus seguidores seria só uma questão de tempo e de trabalho, de muito trabalho religioso.

Para se compreender com mais exatidão os mecanismos desenvolvidos pelos espíritas neste sentido, nada mais apropriado do que tomar como base de análise os artigos de Bezerra de Menezes escritos em O Paiz. Desde os livros e artigos de Antônio Sayão, Bittencourt Sampaio, Leopoldo Cirne e tantos outros companheiros e seguidores de Bezerra de Menezes, até seus próprios estudos e escritos, fosse no Reformador, fosse em outros veículos da imprensa; todas essas obras tiveram como sustentáculo os “Estudos Filosóficos”. Os esforços de estruturação do espiritismo aparecem de uma forma bastante clara e direta nesses artigos, sobretudo porque neles Bezerra não só dialogou com o catolicismo, enunciando as diferenças e as semelhanças entre ambos, como também ajudou a construir a história e, por conseguinte, a legitimidade do espiritismo no Brasil.

Convém inserir aqui uma discussão bastante pertinente ao tema por hora abordado. Há na literatura acadêmica brasileira outro tipo de classificação dos trabalhos sobre o espiritismo - classificação distinta daquela já mencionada no capítulo anterior. Preocupados sempre em analisá-lo nas possíveis relações de semelhanças/diferenças com as crenças afro-brasileiras ou com o catolicismo, esses trabalhos também se dividem em duas posições: uma que considera o espiritismo como parte de um continuum mediúnico que iria dos cultos mais africanizados até o mais ortodoxo espiritismo, enfatizando assim as semelhanças entre os pólos; e outra posição que valoriza muito mais as 
diferenças entre eles. Em todos esses escritos, a palavra espiritismo pode ser encontrada referindo-se a toda crença na possibilidade de comunicação com o “além” - seja com espíritos, seja com orixás - por intermédio dos chamados médiuns. Estão incluídas nessa classificação as religiosidades classificadas como mediúnicas, num gradiente que vai da umbanda ao espiritismo especificamente denominado kardecismo, passando por uma multiplicidade de formas intermediárias resultantes de mútua influência e hibridação dos extremos.

O representante mais importante e mais influente desse modo de interpretação é Cândido Procópio Ferreira de Camargo, cujo clássico Kardecismo e Umbanda (1961), foi ligeiramente retrabalhado no capítulo “Religiões mediúnicas no Brasil” do livro Católicos, Protestantes, Espíritas (1973). Também pensam dessa forma os antropólogos franceses Marion Aubrée e François Laplantine (1990). Idéia semelhante percebe-se em expressões como "adeptos de qualquer religião de possessão" ou "adeptos de práticas mediúnicas” no livro de Maria Helena Vilas Boas Concone, Umbanda: uma religião brasileira (1987), no de Lísias Nogueira Negrão, Entre a cruz e a encruzilhada (1996a), no de Renato Ortiz, A morte branca do feiticeiro negro (1988), no de Yvonne Maggie, Medo do feitiço (1992), no de Vagner Gonçalves da Silva, Candomblé e Umbanda (2005), no de Diana Brown, Umbanda e Política (1985), entre outros. Já Maria Laura Cavalcanti, autora do livro O Mundo Invisível (1983), prioriza sobretudo as diferenças existentes entre esses segmentos religiosos. Por sua vez, Bernardo Lewgoy, em Os Espíritas e as Letras (2000) e Chico Xavier (2004), e Jaqueline Stoll, Entre dois mundos: o espiritismo na França e no Brasil (1999), distantes das relações entre espiritismo e religiões afro-brasileiras, vão enfatizar as semelhanças entre catolicismo e espiritismo.

Bem, se olharmos para a história do espiritismo, desde a sua chegada ao Brasil a igreja católica tentou igualá-lo às crenças afro-brasileiras e assim “rebaixar” de uma só vez todas as crenças ou visões de mundo distintas das que 
ela propunha. Foi nesse sentido que se expressaram os representantes do catolicismo, desde a Pastoral de 1867, numa profusão de artigos de revistas e jornais católicos, até os livros do mais famoso dos defensores da fé católica contra o espiritismo, Frei Boaventura Kloppenburg. De sua parte, os intelectuais do espiritismo esforçavam-se por demarcar justamente as diferenças, afastando qualquer mal entendido que pudesse confundir espiritismo e umbanda, o mesmo fazendo os intelectuais da umbanda (lembrando que a diferenciação em relação ao candomblé só seria trabalhada pelos intelectuais religiosos a partir dos anos 1960-70, momento de consolidação dessa religião no campo religioso brasileiro).

O que estava em jogo nesse processo era, portanto, a disputa em torno das (des)classificações mútuas. Nessa luta simbólica, cada grupo, subgrupo ou estrato social tentava marcar e demarcar diferenças ou distinções significativas frente aos demais: os católicos identificando espiritismo e umbanda; os espíritas, catolicismo e umbanda; os umbandistas, espiritismo e catolicismo.

Assim, tanto as opções que consideram o espiritismo dentro de um continuum mediúnico, quanto as que o consideram nas suas relações com o catolicismo - seja analisando as semelhanças, seja analisando as diferenças tendem a deixar de lado uma questão crucial referente ao próprio processo de formação das religiões e da dinâmica relacional que as envolve. Noutras palavras: tudo faz crer que essas interpretações não costumam levar em conta, além das lutas simbólicas que as religiões travam entre si através de seus intelectuais, as outras lutas, intestinas a cada religião, que têm a ver com as diferentes posições estratégicas tomadas por seus intelectuais a partir das posições estruturais ocupadas pelos diversos segmentos que a compõem. Pensando desta maneira, vejamos o que ocorria internamente ao espiritismo e mais especificamente com o emblemático intelectual do espiritismo: Bezerra de Menezes. 


\section{A construção pela pena}

Domingueiros $^{75}$, seus escritos n’O Paiz também pretendiam popularizar o espiritismo. Mas essa preocupação de alcançar o nível médio dos leitores não tornou impeditiva a Bezerra de Menezes dissertar sobre filosofia e história, e suas correlações com os aspectos religiosos do espiritismo. Embora houvesse certa repetição de temas, perfeitamente compreensível, porque ao total foram 204 artigos, e porque atendiam às circunstâncias das semanas que eram escritos, os motes centrais não deixavam de ser a delimitação, a conceituação, a formulação, e, finalmente, a exposição e a propagação do espiritismo. Em suas crônicas, Bezerra de Menezes demonstrava também preocupações constantes com o estudo do espiritismo à base dos princípios científicos, muito embora não fosse exatamente esse o seu ponto cardeal. Sua formação de médico permitia-lhe tais questionamentos, o que não o impediu, entretanto, de enxergá-lo mais tarde como doutrina especificamente religiosa.

Mas por conta dessa sua ânsia de colocar a razão na frente de tudo, e especialmente neste caso, na frente de sua fé - ou pelo menos lado a lado -, Bezerra começou a série de artigos não só afirmando que o uso da razão era necessário para o entendimento do espiritismo, como seria ele quem a todos levaria inevitavelmente a professá-lo, posto que o espiritismo, por ser uma doutrina racional e coerente, a sua aceitação seria evidente, lógica - inevitável mesmo.

Apesar de cada obra sua ter tido uma função, um viés e um público específicos, a comparação entre catolicismo e espiritismo foi uma constante, sobretudo nos "Estudos Filosóficos” e em Uma carta de Bezerra de Menezes. Nos “Estudos Filosóficos”, por exemplo, há uma série consecutiva de doze artigos diretamente dirigidos contra as "incoerências” da doutrina católica;

75 Todos os seus artigos estão reunidos em dois volumes dos três que compõem a coleção organizada por José de Freitas Nobre intitulada Estudos Filosóficos (BEZERRA, 1977a, 1977b). O primeiro volume é a já mencionada carta de Bezerra a seu irmão (BEZERRA, 1963). 
foram doze semanas trabalhando especificamente o mesmo assunto. Aliás, o diálogo com o catolicismo naquele momento possibilitava exatamente a Bezerra de Menezes ocupar um lugar naquela disputa, ao construir a sua posição através da oposição, apresentando, em contraposição aos bens católicos, os bens de salvação espíritas. É por isso que ele dava tanta ênfase ao ponto principal do espiritismo, que era justamente o signo de diferenciação entre as duas doutrinas: a pluralidade das vidas. Com esse bem em mãos, Bezerra duelava com as concepções de inferno, purgatório e céu, para ele totalmente incoerentes. Posto isto, é interessante ressaltar que em todos os seus escritos, a expressão pluralidade das existências é muito mais utilizada do que o termo reencarnação, talvez pelo fato de ser ainda a mesma tentativa de afastar-se ao máximo, ainda que terminologicamente, de outras doutrinas ou religiões, principalmente daquelas religiões que o utilizam, sobretudo as orientais. A palavra karma também entra de forma idêntica nessa sua estratégia. Ela tampouco é usada por Bezerra, como o é recentemente no meio espírita ${ }^{76}$. Em seu lugar aparece a expressão "lei de ação e reação”. Podemos dizer então, para concluir, que a sua intenção foi mesmo a de demarcar um distanciamento e uma distinção em relação às demais religiões.

Escrevia, portanto, a fim de:

[...] provar aos homens da ciência como a idéia da pluralidade de existências tem passado pelo cérebro dos maiores vultos humanos de todos os tempos e lugares - e ao clero católico que os princípios espíritas têm seus fundamentos nas sagradas letras [...]. (BEZERRA, 1977b, p. 196)

Seu trabalho pode ser dividido da seguinte forma: a sua carta, embora a princípio tenha sido dirigida ao irmão, trazia um conteúdo especificamente voltado às pessoas mais instruídas, intelectuais religiosos ou não, uma vez que

${ }^{76}$ A expressão karma começou a ser mais comum no vocabulário espírita a partir da década de 1940, com alguns escritos, por exemplo, do espírita e presidente da Federação Espírita do Estado de São Paulo, o coronel Edgar Armond, cujas influências vieram dos seus contatos com líderes esoteristas, ocultistas e espiritualistas. 
discutia filosófica e historicamente os princípios do espiritismo. Já os artigos d'O Paiz foram direcionados, sobretudo, aos leigos - crentes ou não - e ao clero mais baixo, e tinham como propósito expor as bases da doutrina espírita a um público mais amplo e variado, numa tentativa de criar mais adeptos. Os artigos do Reformador, por sua vez, dialogavam com os grupos internamente dispostos no movimento espírita, principalmente com os espíritas não religiosos. Além deles, Bezerra também escrevia neste periódico folhetins de fundo doutrinário-moral sempre assinados com seu pseudônimo Max ${ }^{77}$. Dessa maneira, Bezerra de Menezes trabalhava em todas as direções possíveis em prol do espiritismo e de sua propagação, desde o desenvolvimento da sua construção teórica - inicialmente inscrita nas obras de Allan Kardec -, passando pelo trabalho de proselitismo, até a defesa do seu espiritismo frente às demais correntes do movimento espírita. E ainda ia mais além, já que lutou à frente da presidência da FEB pela sua legalização e organização institucional.

\section{E assim Bezerra de Menezes começava os "Estudos Filosóficos”:}

Iniciemos o estudo comparativo da cosmogonia católica com a espírita.

Para isso é preciso, antes de tudo, que levantemos o edifício de uma e de outra, sobre suas respectivas bases: a vida única seguida do juízo definitivo, e as vidas múltiplas seguidas, cada uma, do julgamento das obras que nelas praticamos. (BEZERRA, 1977b, p. 37)

A pluralidade de existências constrói uma cosmogonia admirável e tão digna do Ser Supremo como é mesquinha e repugnante a que se baseia no princípio da vida única [...].

Ver-se-á como tudo que repugna à razão e à consciência, segundo a explicação da cosmogonia fundada na vida única, resplende

\footnotetext{
${ }^{77}$ São de sua autoria, por exemplo, os folhetins: "A casa mal-assombrada", que teve sua publicação iniciada no Reformador, $1^{\circ}$ de janeiro de 1891; "História de um sonho", publicado a partir de $1^{\circ}$ de setembro de 1896; e "Casamento e Mortalha", presente no Reformador a partir de $1^{\circ}$ de janeiro de 1898.
} 
de luz, segundo a explicação da mesma cosmogonia fundada nas vidas múltiplas.

Ver-se-á a diferença que vai do ensino firmado na letra do Evangelho para o ensino firmado no espírito do Evangelho.

O Espiritismo, trazendo aquela simples verdade, deslocando apenas a base da cosmogonia, torna inexpugnável a sublime doutrina do Redentor, e estabelece por estreitíssimos laços a união da religião e da ciência.

É uma revelação científico-religiosa! (IDEM, p. 20)

Ao deslocar a base da cosmogonia católica, Bezerra propunha torná-la mais coerente. E os métodos racionalistas ou positivos que trazia consigo auxiliavam-no nesse sentido. Partindo de um pressuposto, o da existência dos espíritos, seria apenas o passo seguinte afirmar que o espírito sobrevive à morte do corpo e, quando dele separado, pode comunicar-se com os vivos. As provas experimentais de que Bezerra de Menezes tanto necessitava para justificar a crença nas múltiplas vidas eram exatamente as manifestações dos espíritos, expressas, por exemplo, nos “fenômenos das mesas girantes”.

Partindo do fato, hoje incontestável, das manifestações dos espíritos, que desmorona, por seus fundamentos, o edifício do materialismo, e que não pode ser diabolismo, como diz a igreja, primo porque a existência do demônio provaria contra a onisciência e onipotência, e secundo porque, mesmo que assim não fosse, jamais poderia o espírito do mal ensinar a lei do bem.

Partindo daquele fato, que só pode contestar quem propositalmente o não verificar, chegamos a este apoftegma, também verificável pela experiência:

A humanidade terrestre, encarnada e desencarnada, ou na fase vulgar viva e morta, mantém, entre seus membros, constantes relações. (BEZERRA, 1977b, p. 193) 
Os espíritos existem, comunicam-se e proferem em suas mensagens o dogma da reencarnação. Este dogma, por ser capaz de explicar eficazmente as desigualdades de todas as ordens, tornando o mundo mais lógico e dando-lhe sentido, levaria o homem a aceitar racionalmente a doutrina espírita. É por isso que “o Espiritismo é uma doutrina cujos dogmas não se impõem pela fé, mas pela observação e pela experiência” (BEZERRA, 1977a, p. 21). Entretanto, havia fé na jogada sim. Se há dogma, uma verdade incontestável, um preceito a ser indiscutivelmente seguido, há também a crença nele, na sua eficácia. E tem que existir fé e dogmas, até porque são eles que dão a liga, o tônus da disputa no campo religioso; é sobretudo a fé que cumpre o papel da doxa deste jogo. E é o próprio Bezerra quem fala sobre isso, ao naturalizá-la: “A religiosidade ou a fé não é um sentimento provocado por nossas relações com o mundo, é uma disposição inata de nossa alma” (BEZERRA, 1977b, p. 52). É por isso que o espiritismo, mesmo por todo o seu caráter sistêmico e seu método de conhecimento pretendido científico, não deixava de ser uma religião, e uma religião cristã, no caso. Na verdade, ele era mais do que isso: ele era a Terceira Revelação de Deus.

É desse modo que parte dos espíritas enxergava e ainda enxerga o espiritismo. Para eles, a lei do Antigo Testamento teria sido a Primeira Revelação e teria tido em Moisés a sua personificação; a do Novo Testamento teve-a no Cristo e caracterizou-se como a Segunda Revelação. Seguindo essa lógica, o espiritismo seria, pois, a Terceira Revelação da lei de Deus. Todavia ela não fora personificada em nenhuma individualidade, posto que é fruto do ensino dado não por um homem, mas sim pelos espíritos. Ela seria o resultado da ação de uma plêiade de seres espirituais moralmente mais evoluídos, cada um deles trazendo o seu quinhão de conhecimento aos homens para torná-los sabedores do sentido do mundo material e da sorte que os espera no mundo espiritual. Com o conhecimento revelado não por um único ser, mas por um conjunto deles, a verdade desses ensinamentos compartilhados apresentar-se-ia incólume, imaculada, isenta de qualquer nódoa; seria imparcial porque impessoal. 
Toda essa construção teórica, presente desde as obras de Kardec, sobretudo a partir do Evangelho segundo o espiritismo, mas repisadas aqui no Brasil, fazia com que o espiritismo encontrasse, de um lado, o elo (tão desejado e realmente necessário) entre as primeiras "revelações" e a "codificação" - ao tornar esta última ela mesma uma revelação - e, de outro, se tornasse a opção mais bem construída a ser seguida, porque a mais coerente. Em outras palavras, teria sido sim de Kardec o trabalho de codificar o espiritismo e de Bezerra de Menezes fazer o mesmo no contexto brasileiro, mas ambos os trabalhos teriam sido, na perspectiva espírita, mais "manuais" que "intelectuais”. Ou seja, ao afirmar que a doutrina espírita fora, notar bem, apenas codificada, equivalia a dizer que o conjunto de princípios espíritas sempre existiu desde os tempos mais remotos, formando a Verdade, com "V" maiúsculo, que pairou e paira em todos os momentos entre os diferentes povos; Verdade imutável e perene que respeita o nível de entendimento e de conhecimento da humanidade, surgindo gradativamente, de revelação em revelação, mas que sempre esteve aí, como era no princípio, agora e sempre, por todos os séculos dos séculos. E é de quebra que, com essa noção, o espiritismo expunha uma outra: a de que a humanidade caminha evolutivamente, rumo ao progresso. Firmar a crença na idéia de que os princípios espíritas foram ditados por vários espíritos, era, pois, um modo de despersonificação da Terceira Revelação, o que conduzia à Verdade onipresente e atemporal; e, porque evolucionista e progressiva, essa Verdade era inevitável, cedo ou tarde ela se apresentaria. Daí ser inevitável também a adesão ao espiritismo, adesão guiada pela razão.

É, pois, o princípio básico do moderno espiritismo, ou revelação complementar da messiânica, coisa conhecida dos homens, desde os tempos primitivos. (BEZERRA, 1977b, p. 130)

É por isso que a obra de Moisés tem claros e escuros; tem uma parte divina e outra parte toda humana. (BEZERRA, 1977a, p. 46)

Donde, ainda, e visto que o Cristo declarou formalmente não poder ensinar toda a verdade por causa do atraso de seu tempo, a 
conclusão de que há nos princípios que a Igreja tem por verdades eternas, a parte do erro, que só o tempo, por nosso progresso, pode banir. (IDEM, p. 50)

Tanto é assim que na exposição das bases espíritas ao longo dos 204 artigos de Bezerra de Menezes, o nome de Allan Kardec aparece apenas duas vezes. Isso quer dizer que a divulgação da "Verdade” se apresenta para todos e vem aos poucos, rondando a humanidade. Ela não depende da vontade de um ser somente. Para Bezerra, Kardec teria desempenhado sim papel importante no processo da revelação da “revelação", mas teria sido dele somente o trabalho de organização e sistematização dos princípios espíritas.

Apresentam Allan Kardec como criador do espiritismo, porém isto só por ignorância ou por má fé, para poderem acusar falhas na obra, em razão das naturais fraquezas do autor.

Allan Kardec foi escolhido para missionário da nova lei, da revelação, por sua elevada e bem equilibrada inteligência, não inventou a doutrina espírita. [...] Missionário é coisa muito distinta de messias, e muito inferior [...]. (BEZERRA, 1977b, p. 280)

Portanto, utilizando-se de toda essa construção argumentativa, isto é, sendo a "Verdade" progressiva, o espiritismo conseguiria não só se filiar à tradição judaico-cristã como também, e por isso mesmo, situar-se na história, legitimando-se definitivamente.

A revelação abraânica, é um bruxoleio, comparada com a mosaica; e esta não passa de uma preparação diante da messiânica.

A primeira ensina o que somente pode compreender o homem primitivo: a existência de um Deus, criador, pai e juiz dos espíritos.

A segunda já ensina o que já o homem semi-espiritual pode compreender: os deveres para com Deus e para com o próximo.

A terceira, baixando em tempo de civilização, ergue o sacrossanto edifício da moral, do amor e da caridade. (BEZERRA, 1977a, p. 72) 
Agora sim, como cristão que passou a ser, o espiritismo estava apto a se apropriar da história do cristianismo. É dessa forma que as perseguições de que foi vítima tanto por parte do Estado brasileiro quanto, e sobretudo, por parte dos católicos foram de certa forma caras ao espiritismo. Caras tanto no sentido de dispendiosas, custosas simbolicamente falando, já que foi necessário muito trabalho religioso para que o espiritismo pudesse ocupar uma posição na disputa; quanto caras no sentido de terem sido queridas, benquistas, uma vez que foi exatamente por causa delas que o espiritismo conseguiu introduzir-se “cristãmente” no jogo, logo, de modo legítimo. Elas ensejaram a Bezerra de Menezes fazer comparações com as próprias perseguições sofridas pelos primeiros cristãos nos séculos subseqüentes à morte de Jesus. Apropriando-se da história do cristianismo, o espiritismo lograva ser mais puro, mais cristão que qualquer religião cristã de sua época, porque sofria, como sofrera outrora os primeiros cristãos, as perseguições de seus opositores e caluniadores.

Mas Bezerra de Menezes queria mais que isso. O espiritismo agora não só passava a ter vez no jogo como também começava a almejar o lugar da ortodoxia. Para além dos dogmas comuns com o catolicismo - a existência de Deus, a imortalidade da alma, sua liberdade com a co-relativa responsabilidade -, Bezerra, falando em nome do seu espiritismo, propunha uma espécie de reforma da igreja católica, sobretudo com a implantação em sua doutrina de dois princípios que assentam a doutrina espírita: a comunicação com os espíritos e a reencarnação.

O Espiritismo não quer derruir a igreja, não quer arvorar-se em igreja; o que quer é que Roma aceite as puríssimas verdades, que ele encerra, por vontade do Senhor, abandone o amor pelas mundanidades, que são o seu principal objetivo, apure a lei divina ao crisol da nova revelação, e se faça a verdadeira igreja de Jesus Cristo.

O espiritismo não pede uma fé passiva, que degrada a um tempo a criatura racional e o Criador; o que quer é que, por obstinação inconfessável, não se diga: eu não discuto, eu não quero ver, porque não tomo a sério os fatos que os maiores sábios atestam, 
porque provocam-me o riso estes fatos. Porque um sujeito aí diz que faz coisas semelhantes.

O Espiritismo, nova revelação de altíssimas verdades, que se impõe pelo seu racionalismo e pelas provas materiais, não diz: crê ou morre, crê porque é absurdo, mas sim diz: estuda, examina, e abraça o que diz a observação e a experiência. (BEZERRA, 1977b, p. 275, grifos do autor)

E assim, em termos puramente religiosos, o espiritismo seguia o seu processo de legitimação; um processo cujo diálogo com as crenças já estabelecidas possibilitava ao entrante posicionar-se na competição, obedecendo a determinadas regras, as mesmas que foram sendo estabelecidas ao longo do desenvolvimento do próprio jogo.

Nesse contexto todo podemos, portanto, pensar que, na produção de bens simbólicos, os meios encarregados de sua circulação, tais como livros, jornais, revistas e artigos, fazem parte integrante do aparelho de produção que deve produzir não só o produto - os bens de salvação -, mas também a crença no valor e na eficácia de seu próprio produto. Pois quanto mais se impregna a crença nos leigos, tanto mais se garante a soberania dos próprios "sacerdotes” e tanto mais estará dada a autonomia do domínio social em questão. Concluía Bezerra: “Entre nós [os “sacerdotes espíritas”] e vós, o clero, decidirá o mundo” (IDEM, p. 255).

Sendo assim, a autonomia do campo religioso afirmava-se inicialmente, e afirma-se em parte até hoje, 1) de um lado, na tendência dos especialistas de encerrarem-se na referência autárquica ao saber religioso já acumulado e no saber hermético de uma produção de início destinada aos demais produtores. Entretanto, por mais que seja clara a ruptura entre os especialistas e os leigos, a produção do campo religioso distingue-se do campo de produção intelectual especificamente falando. Isto porque, 2) de outro lado, os especialistas religiosos, por mais que tentem, dedicando ainda parte de seus escritos a isso, não podem restringir sua produção ao saber exclusivamente esotérico, isto é, 
dedicado apenas aos produtores. Eles têm de se sacrificar por necessidade às exigências dos leigos. Foi por isso também que o espiritismo não pôde ser especificamente nem uma ciência nem uma filosofia, como queriam alguns. Isso por dois processos concomitantes: primeiro, ao abrir inevitavelmente a sua produção aos leigos a fim de se expandir e propagar-se, o espiritismo teria passado de uma produção esotérica para outra exotérica; e, segundo, ao dialogar com os católicos, por mais especialista que fosse o clero, este também não fazia e não faz parte do campo de produção intelectual. Por conseguinte, entre outros motivos, o espiritismo não se constituiu no Brasil enquanto uma nova posição nem no campo científico, nem no campo filosófico.

Ou seja, por não realizarem uma produção estritamente ministrada a círculos fechados de ouvintes - como é forçosamente o caso da produção intelectual propriamente dita -, os espíritas tiveram imperiosamente que produzir escritos passíveis de serem ministrados a um público bem mais amplo. Assim, ao invés de uma produção que poderia ser hermética, mais íntima, destinada a um grupo seleto, o espiritismo adotou uma mais vulgar, mais ordinária, pensada exatamente para ser exposta e expandida, talvez pela demanda das "implicações morais” de uma de suas facetas (a religiosa), às quais os espíritas tanto fizeram e ainda fazem referência. Deste modo, o campo de produção de bens de salvação tem a particularidade de posicionar-se entre uma produção esotérica e uma produção exotérica. Daí que, se de um lado, o campo religioso já tem certa autonomia por criar e possuir uma produção acumulativa destinada inicialmente aos demais produtores (esotérica), por outro, quando essa produção expande-se por necessidade ao círculo dos leigos (exotérica), sobretudo em uma situação de pluralismo religioso competitivo, essa autonomia reforça-se, já que há uma transformação nas relações de produção simbólica, conducentes à constituição de um verdadeiro campo de forças e tensões. Assim, entre produtores e leigos/consumidores, as relações reflexivas de criação e de recepção se estabelecem de maneira a compor uma lógica cada vez mais particular de funcionamento. E são, exatamente, as engrenagens da lógica desse exercício que tornam ainda mais autônomas as 
produções de bens religiosos. Desta maneira, a concorrência que se estabelece entre os agentes e as empresas no e em jogo é a concorrência pelo monopólio do exercício legítimo do poder de modificar em bases duradouras e em profundidade a prática e a visão de mundo dos leigos, impondo-lhes e inculcando-lhes um habitus religioso, uma disposição generalizada de agir e de pensar de acordo com os princípios de uma visão sistemática do mundo e da existência.

No entanto, faz-se necessário - e mesmo imprescindível - lembrar que essa autonomia é sempre relativa, no sentido de que ela também se dá, ou melhor, ela se pauta em partes nas suas mais diversas relações com os demais campos de produção simbólica. Neste sentido, os fatores externos serão sempre reestruturados conforme a lógica interna do campo religioso, por meio exclusivamente de seus agentes especializados. Por isso é que a dinâmica de produção/reprodução do campo toma continuamente características especiais relacionadas ao seu momento histórico de delimitação e às disposições próprias de seus agentes. Contudo, os conteúdos religiosos de pensamento não nos deixam simplesmente deduzir que sejam o resultado imediato ou mecânico de forças externas ao campo em que atuam; eles próprios são o mais poderoso elemento plástico das ações intencionais que tomam os especialistas, e portam consigo sua legalidade própria e a potência de se imporem sempre em relação aos demais dentro do campo em que agem.

\section{Bezerra veio trazer a paz e não a espada}

Ao entrar para a presidência da FEB, em 1888, Bezerra de Menezes buscou fazer um trabalho de conciliação entre as diversas vertentes internas ao espiritismo, ao mesmo tempo em que reforçava seu aspecto religioso. Realizando então uma reformulação das idéias espíritas, passou a contribuir também com artigos na revista Reformador, cujos apelos à união e à paz foram inesgotáveis. 
[...] Vêem: 'cada qual fazendo doutrina a seu modo', sem ordem, sem disciplina, sem união, produzindo sem proveito, esterilizando a melhor vontade.

Vêem, portanto, em vez de um trabalho uniforme, sujeito a regras invariáveis, tendendo ao mesmo fim: o alto fim posto pela doutrina, um trabalho disforme, disparatado, sem nexo [...].

[...] A união faz a força, precisamente porque nasce dela o emprego dos esforços de cada um.

Com quanto mais razão, pois, devem os espíritas unir-se, quando precisam de forças para resistirem aos inimigos da Terra e aos inimigos do espaço?

[...] Nas Obras Póstumas de Allan Kardec vem explanada esta importante questão [...]. Os espíritas brasileiros têm uma missão, disse o Mestre, e para desempenhá-la é essencial que comecemos por nos organizarmos, organização baseada na união, união na essência e na forma. ${ }^{78}$

Coube a Bezerra de Menezes a tradução, em 1890, do livro Euvres Posthumes, escritos íntimos de Kardec. Nesse mesmo ano, agora afastado da presidência da FEB, mas atuando no centro Grupo Ismael, realizava semanalmente estudos de duas obras: O Livro dos Espíritos e Espiritismo Cristão ou Revelação da Revelação. Os Quatro Evangelhos (1866) de JeanBaptiste Roustaing, estudos que seriam introduzidos por ele na FEB posteriormente. Aliás, não havia somente a desunião entre científicos e religiosos: entre os próprios religiosos havia os kardecistas (que davam proeminência ao $O$ Evangelho segundo o espiritismo) e os roustainguistas (que adotavam as teses de Roustaing). Bezerra tentava então a todo custo unir a todos, embora nem sempre com igual êxito.

${ }^{78}$ Publicado originalmente no Reformador de 1890; reproduzido em Reformador, 01 agosto de 1920 (grifos do autor), sob o título "Fracos, porque desunidos". 
Em 1894, com a situação política brasileira um pouco mais abrandada, Augusto Elias começou a empregar esforços contra o marasmo que dominara o movimento espírita - marasmo que teve início depois das investidas contra o espiritismo por parte do Estado brasileiro logo depois da criação do Código Penal. Junto com Fernandes Figueira e Alfredo Pereira, Augusto Elias iniciou uma campanha financeira para sustentar e ampliar os projetos da FEB. $O$ Reformador voltou a circular (após três meses parado) e a diretoria retomou também seu programa de neutralidade entre os grupos divergentes. A proposta foi defendida no editorial intitulado "Sectarismo":

O espírita está, pois, em seu verdadeiro posto quando se coloca entre o homem de ciência e o homem de fé, não possuindo as crendices de um, nem, por igual, as negações de outro. Não nos desviemos do nosso lugar. Postos entre a fé e a razão, evitemos os exageros do sectarismo, pois que ele é o verdadeiro inimigo. ${ }^{79}$

Insatisfeitos com a política conciliadora da FEB, os científicos, encabeçados por Angeli Torterolli, abandonaram a instituição e fundaram, no dia 4 de abril de 1894, outra casa federativa, o Centro da União Espírita de Propaganda no Brasil.

Após quatro anos, já no final desse mesmo ano de 1894, Dias da Cruz, o então presidente da FEB, deixa o cargo e passa à vice-presidência. Durante o período em que esteve no poder, criou o "Serviço de Assistência aos Necessitados”, uma organização destinada à prática da caridade espírita que funcionava nas dependências da FEB. Era médico homeopata convicto e como tal foi um dos que atrelou as práticas homeopáticas às práticas espíritas ${ }^{80}$. Seu sucessor, o advogado e professor de Humanidades, Júlio César Leal, também era um ardoroso adepto da homeopatia mediúnica. Prestigiado por todos, foi então eleito presidente da FEB, ficando na sua direção somente alguns meses, até a entrada de Bezerra de Menezes. Entretanto, Júlio César não manteve a

\footnotetext{
${ }^{79}$ Reformador, fevereiro de 1894.

${ }^{80}$ Falaremos mais sobre esse assunto no Capítulo IV.
} 
mesma neutralidade e a mesma diplomacia de Dias da Cruz, passando a apoiar os científicos em detrimento dos religiosos. Realizava sessões, às sextas-feiras, nas quais eram apresentadas teses destinadas à discussão, sem intervenção de sentimentos de religiosidade. Justamente por isso, O Reformador, sob a direção dos religiosos Leopoldo Cirne e Alfredo Pereira, começou a fazer oposição ao presidente, publicando uma série de artigos intitulada "Nossa Missão". Até porque, Julio César, durante seu mandato, além de ter nomeado um representante da FEB para o conselho federativo da recém-criada União Espírita de Propaganda no Brasil, subordinando-a, assim, à União, passou a freqüentar assiduamente o reduto científico, deixando de lado o seu trabalho na Federação, onde quase não aparecia. Os religiosos reagiram prontamente.

Em julho desse ano, a crise chegou ao seu auge. O vice-presidente Dias da Cruz ainda tentou fazer a situação retornar ao equilíbrio, tentativa expressa através do artigo "Tolerância e Bondade”. No entanto, Júlio César Leal, sob pesada resistência interna, acabou renunciando à presidência da FEB e filiou-se definitivamente à União. Percebendo que os religiosos pretendiam tomar o poder e recolocar a FEB na liderança do movimento sob uma bandeira religiosa, Dias da Cruz não assumiu o cargo vago, alegando sua incompatibilidade com qualquer programa radical. Chegara então o momento, a oportunidade tão esperada pelos religiosos. O primeiro passo para a vitória definitiva era eleger um presidente religioso que fosse capaz de garantir a hegemonia interna da FEB e que pudesse também anular a ação dos científicos da União. Leopoldo Cirne e Alfredo Pereira, líderes da movimentação, não tiveram dúvida: a pessoa certa para essa tarefa era o Dr. Adolfo Bezerra de Menezes.

Já desde o final de 1891, passando por divergências internas e ataques externos, a FEB via abalado um processo ainda em seus começos. Essa situação se estendeu até 1895, quando as finanças da entidade já estavam bastante prejudicadas. Foi por isso também que, atendendo a pedidos, Bezerra 
de Menezes voltou a assumir a presidência - um posto que ocupou até à morte em 1900.

Durante o tempo em que esteve afastado do trabalho de unificação à frente da FEB, Bezerra abandonou a postura de eqüidistância entre as diferentes posições espíritas - postura que havia assumido em 1889 na sua primeira gestão - e transformou-se num autêntico representante da tendência religiosa na sua segunda presidência. Essa mudança decisiva talvez tenha tido suas raízes nas influências que os religiosos Bittencourt Sampaio, Antônio Luiz Sayão e Frederico Júnior exerceram sobre Bezerra durante o período em que ele havia se isolado no Grupo Ismael (também chamado de Grupo dos Humildes ou Grupo do Sayão), principal reduto do pensamento religioso e roustainguista que mais tarde passou a funcionar nas dependências da FEB. Teria sido, portanto, durante essa fase que Bezerra de Menezes aprofundara seu conhecimento sobre Os Quatro Evangelhos de J.-B. Roustaing, tornando-se assim, posteriormente, um confesso defensor da obra. Basta comparar as duas gestões de Bezerra e logo veremos que enquanto a primeira teve até certo colorido científico, a segunda foi claramente cravejada de religiosidade e de influências roustainguistas. Aliás, podemos ver esse mesmo movimento em suas obras. Tanto em Uma carta de Bezerra de Menezes quanto na série de artigos "Estudos Filosóficos”, sua preocupação ainda pendia para os caracteres filosófico, científico e positivo do espiritismo. Empenhava-se em mostrar um espiritismo lógico, coerente, racional, sistemático, um pouco diferente do que veio a mostrar depois da sua adesão às idéias roustainguistas.

Adolfo Bezerra de Menezes assumiu novamente a direção da FEB no dia 3 de agosto de 1895, numa assembléia em que os estatutos da instituição foram reformados, concedendo-lhe poderes absolutos. Com suas forças ilimitadas, Bezerra tornara obrigatório o estudo da obra de J.-B. Roustaing ao lado do Livro dos Espíritos. Em novembro do mesmo ano, Bezerra iniciava então o seu "apostolado" agora à frente da instituição (numa segunda presidência muito mais autônoma), uma vez que ele já o havia iniciado em 
outras frentes, principalmente com os seus primeiros escritos tempos antes. E assim, este seu trabalho mais duro de uniformização do espiritismo começou com uma série de artigos publicados no Reformador contra os científicos e contra o Centro da União Espírita de Propaganda no Brasil.

Bezerra de Menezes trazia consigo capital externo (ao campo religioso) por ter sido o responsável, quando na prefeitura, das finanças da municipalidade, sendo por isso considerado o único capaz de reequilibrar a situação. Mas por mais paradoxal que pareça, Bezerra teve problemas em suas finanças particulares, ficando reduzido à pobreza em 1892. Ninguém ao seu redor desconhecia a luta econômica em que a sua família se debatia, mas tudo o que ele fazia era em prol do espiritismo e da ajuda aos necessitados. Este foi também um dos fatos que o levou a ser reconhecido como o “Apóstolo do Espiritismo”.

Enquanto portador da moral cristã de caridade e de ajuda ao próximo, Bezerra de Menezes não poderia agir de outra forma senão buscando angariar no próprio campo religioso o capital necessário para a legitimação de sua obra. Fora dele, já havia acumulado todo o capital cabível em suas possibilidades, fosse na política, fosse na medicina, e desses capitais soube bem utilizar-se para a sua entronização pessoal no campo religioso.Vale a pena frisar, para finalizar esta exposição, que foram esses os capitais que possibilitaram a Bezerra de Menezes conquistar as posições em que passou a se encontrar. Entretanto, internamente ao campo religioso e à sua lógica imanente, faltavalhe granjear seu próprio capital de reconhecimento, uma espécie de capital espiritual, digamos, o que produziria efeitos simbólicos bastante importantes para o seu trabalho pessoal. Esse capital, ou seja, essa propriedade que pode tomar diversas formas - desde riqueza, até força argumentativa, eloqüência, certos conhecimentos ou mesmo o domínio de uma rede de relações sociais; um conjunto de habilidades e/ou poder de encantar, de seduzir - quando percebido pelos demais agentes do campo, dotados de categorias de percepção e de avaliação para isso, se torna simbolicamente eficiente. Age como uma 
força mágica, já que aquele que a detém passa a ser reconhecido pelos outros ocupantes do campo. Uma propriedade que, por responder às "expectativas coletivas”, socialmente constituídas em relação às crenças, exerce uma espécie de ação de acatamento social. Então foi assim que Bezerra de Menezes dedicou-se a prestar auxílios médicos no centro espírita, passando dos ideais à ação e vertendo seu capital externo em interno ao campo religioso. Com sua obra de caridade - que começara um pouco antes de sua adesão ao espiritismo, posto que já possuía essa predisposição, mas que se propagou enormemente depois dela - passou a ser reconhecido como o "médico dos pobres”, atendendo a pessoas sem condições de pagar o tratamento, uma vez que para ele,

Um bom médico não tem o direito de terminar uma refeição, nem de escolher a hora, nem de perguntar se é longe ou perto, quando um aflito lhe bate à porta.

O que não acode por estar com visitas, por ter trabalhado muito e achar-se fatigado, ou por ser alta noite, mau o caminho ou o tempo, ficar longe ou no morro; o que sobretudo pede um carro a quem não tem com que pagar a receita, ou diz a quem lhe chora à porta que procure outro, - esse não é médico, é negociante da medicina, que trabalha para recolher capital e juros dos gastos da formatura. Esse é um desgraçado, que manda para outro o anjo da caridade que lhe veio fazer uma visita e lhe trazia a única espórtula que podia saciar a sede de riqueza do seu espírito, a única que jamais se perderá no vaivém da vida. (GAMA, 2001, p. 70)

Permeando seu trabalho de unificação do movimento espírita pela disciplinarização dos grupos, lá estava sua "obra de caridade”, pedra de toque da legitimação do espiritismo brasileiro desde então. Para Bezerra de Menezes, os espíritas deveriam reunir-se em torno das verdades expressas no Evangelho a fim de compreender e divulgar o espiritismo. Dessa forma, as sessões dos grupos espíritas deveriam necessariamente contemplar também o estudo dos evangelhos e prever uma parte importante à caridade, fosse através da “doutrinação dos espíritos sofredores do espaço”, fosse trabalhando para os 
necessitados "encarnados". A cura das almas e a assistência religiosa e/ou material aos indivíduos eram, portanto, precisamente os instrumentos que o ajudariam a angariar o capital que tanto almejava e necessitava. A idéia então de um espiritismo fundado no Evangelho e, consequentemente, na caridade fraterna se contrapunha competitivamente à modalidade que enfatizava as “manifestações dos espíritos” e à modalidade filosófica, que serviam, segundo ele, somente como alimento da vaidade e pretensa cultura, incapazes de operar uma "reforma íntima", necessária para o progresso dos espíritos. Nesses termos, Bezerra de Menezes procurava estabelecer o "verdadeiro caráter" da doutrina espírita.

E qual era esse caráter? A então doutrina deveria ser capaz de conciliar fé e verdade, ciência e religião, e ter como objetivo superior a moral cristã, tal como entendida no Evangelho segundo o espiritismo e n'Os quatro evangelhos. Foi assim que Bezerra de Menezes buscou unificar o movimento espírita como via de salvação religiosa, única via de sua salvação no Brasil.

\section{A guerra santa}

A disputa entre as posições espíritas continuou e o fim do Centro da União de Propaganda no Brasil deu-se em 1897, depois de um pouco mais de dois anos de combate contra a FEB pela liderança do movimento espírita. Algumas batalhas deram corpo a essa verdadeira guerra ideológica travada nas páginas da imprensa espírita. De um lado, Bezerra de Menezes comandando os religiosos; de outro, o professor Angeli Torterolli liderando os científicos.

Em 15 de novembro de 1895, a luta iniciava. Bezerra de Menezes publicou seu primeiro artigo aberto contra os científicos no Reformador, "Res non verba", e durante os três primeiros meses do ano seguinte assinou a série intitulada "Os tempos são chegados". "Falsos profetas" foi outro artigo seu publicado em 15 de março de 1896. 
Mas é claro que a União não se manteve calada. No mesmo ano passou a clamar a manifestação dos centros espíritas através do próprio Reformador ${ }^{81}$ sobre o problema da conceituação do espiritismo, afirmando que suas posições doutrinárias não eram infalíveis, posto não serem religiosas.

Depois de publicar em $1^{\circ}$ de maio de 1896 o artigo "Pelo fruto se conhece a árvore”, Bezerra de Menezes lançou um outro, em $1^{\circ}$ de julho deste mesmo ano, chamado “Espiritismo - ciência ou religião?”. Foi então que Angeli Torterolli, chefe da União, em contra-ataque, escreveu:

Os argumentos produzidos pelo Dr. Bezerra de Menezes, em prol da sua orientação espírita, não passam de vistosas bolhas de sabão, sopradas pelo seu misticismo para deslumbrar a simplicidade ignorante dos que não sabem ou não querem se dar ao trabalho de raciocinar.

Como pode a religião ser ciência, se uma é produto da presunção e a outra é resultado da evidência? Se a primeira é hipotética e a segunda é positiva? Se aquela é estacionária e esta progressiva?

Não! A religião não é ciência, porque a ciência sempre foi e há de ser sempre a formidável adversária da religião. ${ }^{82}$

${ }^{81}$ Através do Ofício $\mathrm{n}^{\circ} .248$ publicado no Reformador, $1^{\circ}$ de maio de 1896 . Havia neste periódico um espaço reservado a outras instituições espíritas que não a FEB destinado a publicar algumas de suas intervenções.

${ }^{82}$ Este trecho foi retirado do livro do espírita Sylvio Brito Soares (2006. p. 113), no qual o autor afirma que o texto é de autoria do "chefe" da "tal União" (IDEM, p. 112), ou seja, de Angeli Torterolli. Entretanto, tanto no site <http://www.novavoz.org.br/bhu-002.htm> quanto no Reformador, 2 de novembro de 1896, num artigo-resposta a Torterolli assinado por Bezerra de Menezes (intitulado Fiat Lux I), este mesmo trecho é atribuído ao científico Vitor Antônio Vieira, que o teria publicado no Jornal do Brasil em 10 de outubro de 1896, compondo uma extensa e pesada matéria crítica aos artigos de Bezerra de Menezes. A confusão talvez tenha explicação no fato de, anos mais tarde, Angeli Torterolli ter publicado em seu livro O Espiritismo no Brasil e em Portugal o artigo de Vítor Antônio Vieira, originalmente veiculado no Jornal do Brasil. No artigo-resposta de Bezerra de Menezes, ele mesmo se dirige de forma contrária e indistinta tanto a Torterolli quanto a Vitor Vieira. Certo é 
Em 15 de agosto de 1896, Bezerra publicou o artigo "A verdadeira propaganda” no qual criticava diretamente a posição de Angeli Torterolli. Tanto Torterolli quanto seu colega, outro científico, Vitor Antônio Vieira, defendiam a idéia de que Jesus não era seu Senhor e sim seu irmão e seu igual; e que o espiritismo era uma filosofia social baseada na ciência espírita, integral e progressiva, que procura a conquista do bem-estar na vida terrena; nessa lógica, o Evangelho seria, portanto, uma espécie de código civil. Ambos receberam prontamente a resposta de Bezerra, fossem nos seus escritos de agosto,

Do que serve pregar o Espiritismo, que é o Evangelho segundo o espírito e a verdade, dando aqueles que o pregam o exemplo do seu desrespeito pelo modo irreverente de pregá-lo?

Sancta sancte tractanda sunt: as coisas sagradas devem ser com todo o respeito tratadas ${ }^{83}$;

fosse meses depois, na série de artigos denominada "Fiat Lux", exclusivamente dirigida contra eles:

Se espiritismo é ciência e religião, como o ensina a doutrina, porque eliminar-se-lhe a parte religiosa e dar-se-lhe, como característica, a parte científica, ensinando-se que é ele filosofia social baseada em ciências positivas, segundo diz o Centro por seu órgão, nestas palavras: "o espiritismo e o Evangelho deixam de ser uma religião, para serem positivamente um sistema político”?

Nós julgamos que esta opinião é inteiramente contrária à doutrina, que consagra tanto a ciência como a religião; e como a regeneração da humanidade, isto é, sua purificação moral, é o fim exclusivo das revelações mosaica, messiânica e espírita, cremos por isto que tais revelações e, por conseguinte o espiritismo, assentam

que, escrito ou não por Torterolli, o trecho foi totalmente incorporado por este ao ser precisamente reproduzido em seu livro, demarcando definitivamente a sua posição naquela disputa.

${ }^{83}$ Reformador, 15 de agosto de 1896. 
essencialmente na religião, visto que disse o Espírito da Verdade: “o mundo (a ciência humana) é impotente para dar-vos força e consolação".

Assim, pois, sendo o espiritismo ciência e religião, mas dando a religião, que não a ciência, os meios de regeneração, sem a qual não chegaremos a nosso destino que é a perfeição, suprimir esta e colocar aquela como pedra angular, será tudo quanto quiserem, menos compreensão, longínqua sequer, da doutrina espírita.

Esses tais podem ser filósofos, sábios, livres pensadores, nunca, porém, espíritas segundo a doutrina [entendida por Bezerra, claro]. ${ }^{84}$

Com o fim de arrematar de uma vez por todas com a discussão, Bezerra pedia aos espíritas que se decidissem definitivamente entre a FEB ou o Centro da União.

Espíritas. Já conheceis os fundamentos da nossa fé e da fé do Centro da União Espírita de Propaganda.

Escolhei, pois, entre as duas, nunca perdendo de vista o critério que nos legou N. S. Jesus Cristo: pelo fruto se conhece a árvore. ${ }^{85}$

Não me preocuparia do caso, que me diz pessoalmente respeito, e que, por isso, nenhuma importância tem, se não fosse o dever que me corre, na qualidade de presidente da Federação Espírita Brasileira, fazer conhecido o modo tão oposto por que esta e a União Espírita compreendem e propagam a Revelação da Revelação, para que os nossos irmãos estudem, observem, reflitam e aceitem aquele que mais conveniente lhe parecer (...). E, pois, me parece evidente: ou espírita com o Centro de União Espírita, ou espírita com a Federação Espírita Brasileira; ou abraçar a propaganda aparatosa e semi-

\footnotetext{
${ }^{84}$ Reformador, 15 de novembro de 1896, grifos do autor.

${ }^{85}$ IDEM, grifos do autor.
} 
profana, ou a que tem sido acoimada de mística, porque se inspira nos ensinamentos do Evangelho. ${ }^{86}$

Prontamente, Torterolli respondeu:

Lendo esses deploráveis artigos que o presidente da Federação Espírita Brasileira está publicando no Reformador sobre a propaganda do Espiritismo, e não duvidando da boa-fé com que são escritos, causa-me profunda tristeza a confusão, que naquela retórica eclesiástica se faz de revelação, de ciência, de culto e de religião. (SOUZA, 2001, p. 39)

Foi por isso que, tempos depois, Bezerra, para bem se distinguir e se distanciar dos científicos, publicou um aviso, comunicando que ele e a FEB não tinham definitivamente mais nenhuma relação com o Centro da União, explicando que o fato do Reformador divulgar notas e ofícios da União não representava ligação com a entidade e sim mera condescendência. Além disso, como Bezerra de Menezes havia sido membro da União durante algum tempo, era necessário agora a sua declarada e total desvinculação. No entanto, não fora somente decisão de Bezerra a sua saída; pelo que tudo indica, ele havia sido expulso do Centro de União Espírita de Propaganda do Brasil:

Convencido dessa verdade [necessidade de união entre os espíritas] [...] eu fiz o sacrifício de permitir que meu nome, embora sem nenhum valor, figurasse como Diretor do Centro da União Espírita, na esperança de alcançar que aquele centro pautasse sérias obras pelas normas da doutrina [...].

Quando tive pelos jornais profanos o conhecimento de que o Centro da União Espírita, por voto dos seus diretores, me havia expelido de seu seio, em razão de eu ser homem político [...]. A verdadeira razão compreende-se, foi o antagonismo de modos de compreender a propaganda espírita, de compreender o Espiritismo. ${ }^{87}$

\footnotetext{
${ }^{86}$ Reformador, 15 de agosto de 1896, grifos nossos.

${ }^{87}$ Reformador, 15 de agosto de 1896.
} 
Utilizando-se daquela "condescendência”, no mês seguinte, o Centro da União publicou o Ofício no 487 no Reformador, onde explicava o verdadeiro sentido da frase de Torterolli sobre o Nazareno: “Jesus não é meu Senhor e sim meu irmão amado, que me auxilia a chegar até ele”. Nessas palavras o professor se defendia e se posicionava. Para ele, e diferentemente da concepção católica, Jesus não seria o seu senhor, seu superior, mas um espírito igual aos outros só que mais evoluído, moralmente falando; que veio à Terra como um homem, de carne e osso, semelhante aos demais, para ajudar aos necessitados, e não como um deus ou semi-deus, segundo a visão roustainguista, cara a Bezerra. Mas nada disso era suficiente para aquietar o presidente da FEB. Em seu artigo editorial "Clama, não cesses", o médico contestava o lema da União “Amor, Deus e Liberdade”, afirmando que quem não segue Jesus e o fundo moral de seus ensinamentos - notar bem: como Bezerra tentava ditar -, não pode evocar sequer o nome de Deus. Assim, o líder da FEB criticou o uso de flâmulas na porta do Centro da União, pois para ele:

Onde quer que vejais placas e bandeiras, como anúncio permanente de sessões espíritas, crede: aí não está nenhum espírito religioso, e, se gostais de divertir-vos, entrai; e, se procurais o verdadeiro Espiritismo, fugi e orai pelos que o deturpam.

Os templos não têm placas, nem flâmulas, nem arautos pregando pelas ruas e praças ao som de timbales. Esses são meios empregados por empresas teatrais para atraírem concorrência. Isto é próprio de festas mundanas, nunca de exercícios religiosos. ${ }^{88}$

Reivindicou claramente para si o uso exclusivo do espiritismo cristão, do espiritismo religioso, para ele o único verdadeiro. E já que estamos falando de uma guerra com diferentes inimigos posicionados em diversas frentes, Bezerra no mesmo artigo também não perdeu tempo e criticou juntamente a igreja:

${ }^{88}$ IDEM, grifos nossos. 
O sacerdócio hebreu mesclou o culto divino de impurezas humanas, e foi esta a origem da sua condenação.

A Igreja romana fez outro tanto: adora a Deus com os lábios e tem o coração cheio de iniqüidades.

O Espiritismo, Terceira Revelação, complemento da Messiânica, precisa evitar o temeroso escolho [...].

Se os espíritas não compreenderem, melhor que o sacerdócio hebreu e melhor que a Igreja, a sagrada missão de depositários das eternas verdades, do que servirá à Humanidade a Nova Revelação, o orvalho do Céu para acalmar a sede abrasadora dos filhos da Terra?

Espiritismo não é ciência como apregoam os que procuram, nos fenômenos por ele produzidos, antes o maravilhoso do que ensinos de salvação.

Se o Espiritismo fosse ciência, seria invenção ou descoberta dos homens, como têm sido todas as que são conhecidas até hoje [...].

Entretanto, qual é a pedra fundamental do Espiritismo, em sua pura concepção? - O Evangelho.

O Evangelho, sim; porque o fim da revelação espírita, clara e positivamente prescrito pelos seus reveladores, únicos competentes para determiná-lo, é a interpretação do ensino divino em espírito e verdade.

E, se este é o fim posto por Deus, como no-lo ensinam seus emissários, donde os fundamentos para o considerarem ciência?

Ciência é ele, porque altíssima religião; e quem diz religião diz ciência, por ser religião a ciência das ciências.

Neste sentido, e só neste sentido, pode-se dizer que o espiritismo é ciência: Religião científica. 
Querer, porém, destacar os dois elementos, dos quais um procede do outro, é desnaturar a Revelação, tal como fizeram Jerusalém e Roma. ${ }^{89}$

E eis que, como uma cartada final e como forma de tomar para si a apropriação legítima do rótulo espiritismo, Bezerra de Menezes em claro e bom tom dirigiu-se aos espíritas científicos nestes termos:

Os homens da ciência estudam seus fenômenos e procuram explicá-los pelas leis conhecidas da ciência, eis tudo; mas já conseguiram fazer dele [do espiritismo] e por ele, um corpo de doutrina científica? Nada têm conseguido no sentido desse seu maior empenho.

Entretanto, aí está, desafiando as fúrias da incredulidade, o Espiritismo brilhantemente organizado em alta e sublime doutrina religiosa! ${ }^{90}$

Seu trabalho, pois, já rendia frutos. A organização do espiritismo como “doutrina religiosa” através de seus esforços parecia muito mais bem acabado que a tentativa oposta de fazer dele um corpo doutrinário científico. Por falta de capital dos científicos e mesmo por conta de toda aquela configuração histórica, lutar por um espiritismo religioso e transformá-lo realmente em uma doutrina religiosa pareceu uma tarefa mais fácil do que torná-lo um ramo da ciência, ou mesmo da filosofia. Até porque, naquele mesmo momento, o campo científico também começava a se autonomizar, criando seu próprio espaço de atuação e sua própria lógica, que não era a mesma do espiritismo científico. Numa batalha desigual, esse espiritismo não teve realmente forças nem fôlego para lutar neste campo.

No dia $1^{\circ}$ de setembro de 1897, a Revista Espírita do Brasil, órgão oficial do Centro da União, publicou o artigo "Praticamos a ciência espírita e a

\footnotetext{
89 IDEM.

${ }^{90}$ IDEM, grifos nossos.
} 
moral cristã”, assinado pela Diretoria Central do Centro. Nele encontramos a defesa de suas posições doutrinárias:

a) Jesus era um filósofo e, por isso, não fundou uma religião; b) conforme afirmou Kardec, a moral de Jesus é a parte essencial dos Evangelhos; c) não há contradição entre o cultivo da moral cristã e a prática da ciência; d) o Espiritismo é uma ciência integral e progressiva; e) a finalidade do Espiritismo é regenerar a sociedade; f) as posições doutrinárias dos científicos encontram respaldo nos congressos espíritas de Barcelona, Madri e Paris. ${ }^{91}$

Mas mesmo também arrogando para si a moral cristã como última estratégia de sobrevivência, esse espiritismo já estava fadado à escuridão. A resplandecência do peso legitimador que acompanhava, por um lado, os espíritas religiosos, e por outro, os cientistas brasileiros, deixava os espíritas científicos ofuscados em ambos os âmbitos. Buscar uma centelha nesta disputa não parecia nada fácil a esse grupo.

A guerra continuou, mas os científicos não tiveram munições suficientes para vencê-la, ainda que a sua derrota não tenha significado o seu fim. E assim, sob a férrea oposição de Bezerra de Menezes e de seus seguidores, o Centro da União Espírita de Propaganda no Brasil acabou fechando no final de 1897. Com a sua extinção, os científicos desarticularam-se e uma FEB agora mais poderosa, totalmente religiosa e roustainguista, voltou ao comando do movimento espírita. Bezerra de Menezes ganhara a guerra.

Doravante, com uma FEB mais forte e consolidada, com o poder de ditar as coordenadas lídimas, pouco a pouco uma "nova antiga” idéia foi se firmando no horizonte espírita como estratégia de “unir” todas as correntes. Unir entre aspas, pois todas elas deveriam na realidade subjugar-se à corrente religiosa, a mais legítima porque vitoriosa. Agora sim passaríamos a ver um

\footnotetext{
${ }^{91}$ Disponível em:
}

<http://www.universoespirita.org.br/NOVA ERA/BREVE HISTORIA.htm>. Acesso em: 10 maio 2007. 
espiritismo tido simultaneamente como ciência, filosofia e religião: uma tese que realmente interessava à Federação de então. Com ela, os espíritas mais racionalistas acabavam aceitando o lado religioso da doutrina e a FEB perdia o qualificativo único de religiosa, passando a agregar os diferentes grupos sob sua égide. Isso facilitaria a união do movimento em torno dela e a irradiação da sua plataforma doutrinária. Era nesse sentido que Bezerra já vinha trabalhando há tempos.

A desordem que reina o mundo espírita, da qual fizemos o assunto do nosso passado artigo, pode ser comparada ao fenômeno da cristalização, em que os elementos se acham esparsos na massa em fusão, como à espera de um ponto em torno do qual aglomere e solidifique-se, tomando as belas e regulares formas que conhecemos.

Assim, a massa espírita esparsa pela sociedade como que anseia por que lhe dêem um centro em torno do qual se agregue, formando um todo harmônico e estável.

Compreende-se que esse centro não pode ser arbitrariamente escolhido, mas sim o que naturalmente se impõe por qualidades que recomendam à estima e à confiança da maior parte.

Nesse caso - é fora de séria contestação - está a Federação Espírita Brasileira, que sustenta, a longos anos, o jornal espírita de maior circulação no país, e que mantém relações com grande número de associados espíritas dos países estrangeiros.

O Brasil espírita é conhecido no mundo pela Federação, cujo jornal, o Reformador, troca com a quase totalidade dos jornais espíritas da Europa e da América.

É naturalmente o núcleo da cristalização espírita do Brasil, seu centro no país, seu órgão no estrangeiro.

Órgão do espiritismo brasileiro no estrangeiro já ela é, pois que ninguém, fora da nossa terra, conhece outro, e quase todo o mundo espírita o conhece. 
Por que em tais condições, não ser também centro do Espiritismo no Brasil?

A organização que todos reconhecem necessária pede um centro, uma cabeça; qual de nossas associações oferece, por este alto fim, os predicados da Federação?

Seus estatutos são larga bandeira que pode cobrir todas as opiniões divergentes, desde que se dedicam exclusivamente aos estudos e prática da moral espírita, até as que exclusivamente se dedicam ao estudo e prática da filosofia e ciência espíritas.

Tem, pois, a condição para centro, para seio, de todo o movimento espírita e espiritualista. [...] Centro em torno do qual se organizem, e organizados, adquirem uma orientação segura pela convergência de todas as forças [...].

A união sob o regime de federação, não tolhe senão os maus efeitos de uma liberdade transviada [...].

A Federação não quer o poder, que queima, nem a supremacia, que esmaga. A Federação é uma associação espírita, e portanto, tem por lema, amor e humildade. ${ }^{92}$

Noutras palavras, com o “advento” de um “espiritismo polissêmico”, o efeito ideológico da unificação das diferenças e da denegação das divisões deveu-se ao fato de que, à custa das "reinterpretações" de um grupo (o religioso) dotado de mais capital, o espiritismo da FEB conseguiria agora falar a todos os demais grupos, neutralizando-os e acolhendo-os para si e sob seu poder. É nesse sentido que os discursos da Federação Espírita Brasileira não eram apenas signos destinados a serem decifrados e compreendidos; eram também, e sobretudo, signos de autoridade a serem acreditados e obedecidos. Portanto, aspirar, na medida de seus meios, ao poder de nomear, de ditar, de construir e de adjetivar o espiritismo era, no limite, o objetivo que todos ali naquela guerra almejavam, mas foi a FEB que mais dele se apropriou; poder

${ }^{92}$ Reformador, 15 de agosto de 1895. 
este incumbido aos porta-vozes cujas ações e a matéria de seus discursos constituíam um testemunho, a garantia de delegação de que foram investidos pelo grupo. Porque o poder das palavras reside também no fato de não serem pronunciadas a título pessoal por alguém que é tão-somente seu "portador”; o porta-voz é quase um procurador do grupo, que além de concentrar seus próprios capitais também concentra os capitais do grupo que representa.

Desta forma, com a aceitação da tríade ciência-filosofia-religião, os termos, tais como religiosos e científicos, acabaram, pouco a pouco, caindo em desuso até quase desaparecerem. No entanto, a completa união e a verdadeira paz estavam longe de serem atingidas. A defesa da obra de Roustaing pela FEB, por exemplo, que fazia parte das divergências entre religiosos e científicos, passou também a incomodar alguns daqueles que eram adeptos do aspecto religioso da doutrina. Não concordando com as idéias do advogado bordelense, esses religiosos acabaram provocando uma cisão no movimento, pretendido unificado, que perdura até os dias de hoje.

É assim que o combate continua, no entanto, sem um dos seus maiores estrategistas, Bezerra de Menezes. A morte arrebatou-o do campo de batalha no mês de abril de 1900. Vários jornais da capital renderam-lhe homenagens nos termos mais respeitosos, ressaltando sua trajetória política e médica, atuações que o fizeram angariar visibilidade e reconhecimento para si e, por conseguinte, para a instituição à qual doou a vida. Os periódicos A Notícia e Cidade do Rio, por exemplo, registravam no dia 11 de abril daquele ano:

Faleceu hoje, às 11h30min da manhã, o ilustre conhecido clínico Dr. Adolfo Bezerra de Menezes, cavalheiro de altas virtudes e conceituadíssimo em nosso meio social. ${ }^{93}$

Exerceu entre nós o Dr. Bezerra de Menezes vários cargos de eleição popular, sendo considerado por muito tempo um dos mais

${ }^{93}$ A Notícia, 11 de abril de 1900. 
prestigiosos chefes do partido liberal do antigo Município Neutro, durante a monarquia. ${ }^{94}$

Ou ainda os jornais O Paiz e Jornal do Brasil, no dia seguinte à sua morte:

Possuidor de grande fortuna, a política e a prática da caridade empobreceram-no. A sua morte deixa um grande vácuo no coração daqueles que tiveram ocasião de admirar de perto quanto valia aquela alma privilegiada.

Médico, e médico hábil, a sua vida foi, nos últimos tempos, um contínuo labutar em benefício da pobreza; jamais recusou os serviços àqueles que a ele recorriam. ${ }^{95}$

Sucumbiu ontem, às 11h30min da manhã, após longos e dolorosos padecimentos, que foram a última prova imposta à sua resignação verdadeiramente cristã, o eminente brasileiro cujo nome, encimando estas linhas, como homenagem póstuma às virtudes da sua vida, por tantos anos fulgurou nos anais da política do império e hoje apenas vive na tradição dos que o amaram, ou da inexaurível fonte de sua bondade receberam inesquecíveis benefícios. [...] em todas essas manifestações da sua atividade deu sempre o Dr. Bezerra de Menezes as mais brilhantes provas da sua capacidade e do seu valor moral e intelectual; mas foi sobretudo no abnegado sacerdócio da sua clínica e na doce penumbra da sua vida íntima que refulgiram os peregrinos dotes do seu espírito, multiplicando-se em desvelos, em solicitudes, em carinhoso desinteresse por todos os que sofriam. E jamais bateu um desses, enfermo ou necessitado, inutilmente à sua porta. ${ }^{96}$

Como é sabido, para os espíritas Bezerra não morrera simplesmente, apenas começara a viver em outro plano, no “plano espiritual”. Aliás, o tema da morte, designada pelo termo “desencarnação”, sempre foi um tema recorrente no Reformador e em todas as obras espíritas. Tal procedimento constitui-se em

\footnotetext{
${ }^{94}$ Cidade do Rio, 11 de abril de 1900.

${ }^{95}$ Jornal do Brasil, 12 de abril de 1900.

${ }^{96}$ O Paiz, 12 de abril de 1900.
} 
uma forma que os espíritas adotaram para contrapor sua concepção angular da (in)finitude humana à dos católicos e à dos materialistas. Nem um inexorável destino proclamado por um juízo final, temido por uns, nem a desesperança que acometia outros, a "desencarnação", ainda mais seguida pela idéia de reencarnação (um recomeço), proposta pelo espiritismo se apresentava como um bem de salvação mais consolador, mais coerente.

É assim que Bezerra de Menezes continua, mesmo "além-túmulo", influenciando as ações dos espíritas e trabalhando pela expansão da doutrina, à qual se dedicou inteiramente nos seus últimos anos enquanto "encarnado”. São muitas as mensagens e livros recebidos por médiuns e "assinados” por Bezerra de Menezes; são seus ideais e sua visão de espiritismo que vigoram até os dias de hoje entre a maior parte dos seguidores e adeptos do espiritismo religião.

Deste modo a Federação, ou, antes, Bezerra de Menezes porque Bezerra era a alma da Sociedade - se constituiu o eixo em torno do qual haveria de girar a orientação de todo o sistema do Espiritismo no Brasil. (RIBEIRO, 1941, p. 24) 


\section{Capítulo III - A produção de um espiritismo religião}

\section{A matriz do espiritismo religião}

O trabalho de "sistematização casuístico-racional" e de "banalização" (Cf. WEBER, 2000a) iniciado por Bezerra de Menezes pôs as condições necessárias e fundamentais para o funcionamento da FEB, uma instituição burocrática com a função de manipular os bens de salvação no sentido de permitir a quaisquer agentes, isto é, permutáveis, o exercício de modo contínuo das atividades necessárias ao espiritismo. A FEB fornece aos espíritas, além do seu aval legítimo, os instrumentos práticos indispensáveis para o cumprimento de sua função - material impresso (livros e revistas) entre outros materiais, e o próprio espaço físico da instituição. Reduzem-se assim o custo do trabalho de produção simbólica para os novos participantes no jogo (uma vez que o grosso do trabalho religioso já foi realizado pelos iniciadores do movimento) e a vulnerabilidade da nova religião. É por isso que os escritos de Bezerra de Menezes servem de roteiro, de ponto de apoio, moderando o surgimento de extravagâncias e excentricidades, pondo limites, assim, à economia da improvisação. Daí o recurso incessante aos trabalhos e ao modo de pensar de Bezerra de Menezes, isso feito principalmente ao modo espírita, ou seja, através das inúmeras psicografias assinadas com seu nome. Por essa razão, pode-se dizer conclusivamente que, entre todos os participantes do jogo, foram justamente os jogadores que mantiveram sua participação ativa dentro dos limites iniciais do espiritismo religião os que mais capital simbólico agregaram ao seu nome, noutras palavras, os que mais reconhecimento angariaram.

Entretanto, cabe ir além e fazer transparecer aqui que as bases da fundação do espiritismo religioso não foram erguidas somente por Bezerra de Menezes, muito embora o seu papel tivesse sido, indiscutivelmente, de fundamental importância. Nesse trabalho inicial de armação teórico-doutrinária 
do qual o espiritismo-cristão é o resultado, houve um grupo de agentes que se envolveu ativamente na construção de seus alicerces, agentes que fizeram parte do já citado Grupo Ismael, ou Grupo dos Humildes, também denominado Grupo do Sayão, criado em 15 de julho de 1880.

Principal núcleo do pensamento espírita religioso, o grupo teve como fundador o advogado Antônio Luiz Sayão, e era composto pelo funcionário público Frederico Pereira da Silva Júnior (o mais importante médium dessa agremiação), pelo funcionário da Alfândega João Gonçalves do Nascimento, por Isabel Maria de Araújo Sampaio, por Manuel Antonio dos Santos Silva, pelo jornalista e literato Francisco Leite de Bittencourt Sampaio, entre outros. Alguns desses integrantes, sob a liderança deste último, foram os mesmos que anos antes haviam feito parte da Sociedade Deus, Cristo e Caridade (1876), que por sua vez havia sofrido com rachas internos e passara a se chamar Sociedade Acadêmica Deus, Cristo e Caridade (1879), grupo predominantemente científico apesar do nome. Assim, os dissidentes religiosos da primeira sociedade fundaram, sob o comando de João Gonçalves do Nascimento, em 21 de março de 1880, o Grupo Espírita Fraternidade. De orientação evangelicista, esse grupo ficou conhecido pelos seus trabalhos de “desobsessão”, ali se estudando, nas sessões ordinárias, o Evangelho segundo a perspectiva apresentada por J.-B. Roustaing. O Fraternidade prosseguiu com a orientação evangelicista até se transformar em Sociedade Psicológica, esta desaparecendo em 1893. Seus participantes religiosos fizeram parte posteriormente do subseqüente (e seu herdeiro direto) Grupo dos Humildes ou Grupo do Sayão (porque por ele dirigido), mais tarde denominado Grupo Ismael (por extenso: Grupo de Estudos Evangélicos do Anjo Ismael), quando integrado à Federação Espírita Brasileira, de 1884, onde existe até hoje. Podese observar a definição dos grupos através da preocupação de seus adeptos em renomear suas agremiações assim que elas passavam a tomar um novo caráter. “Acadêmica”, "Psicológica”, entre outros, eram todos adjetivos utilizados por aqueles que estavam mais interessados no lado científico ou mesmo filosófico do espiritismo, enquanto que "Humildes”, “Evangélicos”, "Fraternidade”, 
“Confúcio”, "Ismael” (estes dois últimos são nomes de "espíritos-protetores”) eram as referências dos espíritas religiosos. Formas, portanto, de demarcar as diferenças e de se posicionar perante os demais, até no léxico.

$\mathrm{Na}$ realidade, esses processos todos de fundar, cindir, reagrupar e participar de diversos grupos concomitantemente faziam parte de um movimento bem característico do início do espiritismo no Brasil, como dito anteriormente. Os adeptos espíritas transitavam, não sem tensões, entre os diversos segmentos, tendo como referências básicas as tematizações "ciência", "filosofia" e "religião" em suas variadas e complexas articulações (às vezes também um tanto desconexas). É por isso que para efeitos de análise desse processo, é importante, e mesmo indispensável - tornamos a dizer - enfatizar que tais classificações só são entendidas aqui em termos típico-ideais. Isso quer dizer que tomar o "grupo dos religiosos" como foco da análise implica saber que, fora desse foco, ele se apresenta como um conjunto de pessoas interrelacionadas e interdependentes que percorriam diversos agrupamentos associativos espíritas, mas cuja predominância temática de toque era indubitavelmente a religiosa.

No interregno de suas duas presidências na FEB, Bezerra de Menezes isolou-se no Grupo Ismael. Foi lá, durante essa fase, que ele aprofundou seu conhecimento sobre Os quatro evangelhos, obra de Jean-Baptiste Roustaing, tornando-se posteriormente seu defensor e propagador. Tanto é que, se compararmos suas duas gestões à frente da Federação, veremos que, embora exaltasse também as facetas filosófica e científica do espiritismo durante sua primeira gestão, além, é claro, de seus aspectos morais, sua segunda presidência foi muito mais embebida de aspectos religiosos de clara influência roustainguista. Não foi por acaso, portanto, que o importante trabalho de vincular o Grupo Ismael à Federação Espírita Brasileira tenha sido articulado e realizado por Bezerra de Menezes quando de seu segundo mandato.

Eleito outra vez, Bezerra começou de forma mais aberta e convicta a imprimir à FEB uma orientação basilarmente evangelicista, invocando para 
legitimação dessa inflexão as mensagens psicografadas e assinadas por ninguém menos que Allan Kardec e o Anjo Ismael, este proclamado através das psicografias recebidas no Grupo do Sayão como o “espírito protetor” do Brasil e de sua população.

Reunidos em nome de Ismael, não tendes outros deveres senão estudar os Evangelhos à luz da Santa Doutrina. Allan Kardec. (WANTUIL, 2002, p. 234)

A missão dos espíritas, no Brasil, é divulgar o Evangelho em espírito e verdade. Ismael (IDEM)

O fato é que Bezerra já conhecia Os Quatro Evangelhos de Roustaing antes mesmo da sua segunda presidência, mas foi somente a partir do seu último mandato, muito mais autônomo - porque recebera poderes ilimitados que ele instituiu seu estudo obrigatório no novo estatuto da FEB, ao lado do estudo sistemático do Livro dos espíritos em sessões públicas semanais. Portanto, o que havia ocorrido a partir de então em termos mais precisos foi um aumento na divulgação da obra de Roustaing e a subseqüente definição do espiritismo cristão em sua forma mais polêmica.

Entretanto, a acentuação da propaganda das idéias roustainguistas naquela época não fora somente obra perseguida por Bezerra de Menezes. Dois outros espíritas igualmente importantes intermediaram sua difusão no Brasil: Francisco Leite de Bittencourt Sampaio e Antônio Luiz Sayão. Somando-se a Bezerra de Menezes, foram esses três os primeiros grandes construtores do espiritismo religioso. Certamente existiram muitos outros - imprescindível ressaltar - que, participando da economia da produção dos bens de salvação, acabaram por fazer algumas contribuições e mesmo algumas modificações; enquanto outros ainda foram radicalmente contrários à concepção espírita defendida pela “trindade” do espiritismo evangelicista, mesmo que também fossem, esses outros, tidos como espíritas religiosos. Seja como for, cabe salientar que, para além das diferentes e não raro divergentes posições tomadas quanto ao espiritismo religião, o fato é que esses agentes desenvolveram, com a 
ajuda posterior que tiveram de seus seguidores, uma conformação peculiar de um modo de ser espírita no Brasil. Nos dias de hoje, não faltam seguidores dessas três lideranças espíritas para reconhecer o mérito e a validade do seu trabalho. “Às colunas do espiritismo: Antônio Luiz Sayão, Bezerra de Menezes, Bittencourt Sampaio": esta aí é a dedicatória feita por um escritor espírita cuja obra, Ponte evangélica (de Bordéus a Pedro Leopoldo), narra a passagem das idéias do advogado bordelês da França para o Brasil, idéias que foram compartilhadas, entre outros importantes espíritas, por Chico Xavier, o maior nome do espiritismo brasileiro no século XX, nascido justamente em Pedro Leopoldo, cidade que o subtítulo do livro homenageia. Foi através da propalada faculdade mediúnica de Chico Xavier que as múltiplas angulações de Os quatro evangelhos foram definitivamente legitimadas e mais ainda propagadas.'

Se desde Bezerra de Menezes - juntamente com seus seguidores Bittencourt, Sayão, entre outros - o programa Kardec-Roustaing já era uma realidade, foi somente com a publicação do livro Brasil: coração do mundo, pátria do evangelho, obra psicografada por Chico Xavier em 1938, que ele se tornou "espiritualmente" legítimo. Uma de suas primeiras obras "recebidas mediunicamente", esse livro relata a "preparação espiritual” do Brasil como terra prometida do cristianismo na América, missão que seria totalmente cumprida com a chegada do espiritismo em seu território. O autor, supostamente o espírito do escritor Humberto de Campos (1886-1934), narra os fatos históricos desde as grandes navegações e a chegada dos portugueses em terras brasileiras, até os acontecimentos no Brasil do século XX, explicando (ou melhor, interpretando) os fatos sempre à luz do espiritismo. Conta igualmente a trajetória dos núcleos espíritas anteriores à FEB (mais precisamente dos núcleos religiosos), bem como a sua fundação e a história dos principais agentes dessa instituição; isso tudo como se a existência tanto da FEB quanto desses agentes tivesse sido providencialmente programada desde os tempos mais remotos. A história do Brasil aparece como uma espécie de epopéia 
espiritual comandada pelos desígnios dos espíritos ${ }^{97}$. Era dessa forma então que o tradicional programa da FEB, a autodenominada "Casa-Máter" do espiritismo no Brasil, passava a ter uma nova natureza: ele era, agora, consagrado.

Foi assim que Allan Kardec, a 3 de outubro de 1804, via a lua da atmosfera terrestre, na cidade de Lião. Segundo os planos de trabalho do mundo invisível, o grande missionário, no seu maravilhoso esforço de síntese, contaria com a cooperação de uma plêiade de auxiliares de sua obra, designados particularmente para coadjuvá-lo, nas individualidades de João-Baptista Roustaing, que organizaria o trabalho da fé [...]. (XAVIER, 1982, p. 173)

E assim, não só o programa da FEB tornava-se consagrado, mas também toda a história de vida dos principais agentes desse órgão.

Os mensageiros de Ismael, triunfando da discórdia que destruía o grande núcleo nascente [o Grupo Confúcio], fundavam sobre ele, em 1876, a "Sociedade de Estudos Espíritas Deus, Cristo e Caridade", sob a direção esclarecida de Francisco Leite Bittencourt Sampaio, grande discípulo do emissário de Jesus, que, juntamente com Bezerra, tivera a sua tarefa previamente determinada no Alto. A ele se reuniu Antônio Luiz Sayão, em 1878, para as grandes vitórias do Evangelho nas terras do Cruzeiro. (IDEM, p. 185)

Uma das características da literatura espírita (sobretudo se é do gênero biografia) é o emprego freqüente de um tom não apenas edificante, esperado em qualquer literatura de divulgação religiosa, mas também e sobretudo emotivo, exageradamente sentimental e melífluo, não se entende bem por quê, além da dedução óbvia de que essa escrita diz muito tanto daqueles que a produziam quanto daqueles que a consumiam. E isso até os dias de hoje. Outra característica corrente nos escritos espíritas, e isso também até os dias de hoje, é o uso de uma linguagem excessivamente empolada, afetada, carregada de

${ }^{97}$ Para saber mais, ver SILVA, Luiz da (2005). 
adjetivos os mais inusitados, conformando um linguajar dominado por uma cultura que se pretende sofisticada, mas é apenas bacharelesca, tamanha a necessidade de demonstrar no modo de escrever um status adquirido de escolaridade superior à da maioria dos brasileiros; quem sabe, tamanha a necessidade de apresentar algo intelectualmente elevado, que se possa reconhecer como digno de respeito e consideração. Afinal de contas, o que estava em jogo (e dá para dizer que sempre parece estar) no caso do espiritismo no Brasil é a busca de aceitação e respeito também pela "boa apresentação" e "boa aparência” do seu discurso escrito, da sua literatura de vulgarização, na qual se veicula, ao fim e ao cabo, o teor fora do comum e duplamente heterodoxo de um espiritismo que se fez religioso. É com esse linguajar pomposo e de certa forma pedante que as lideranças espíritas buscavam cavar seu espaço no campo religioso brasileiro, sendo para tanto necessário se demarcar com traços ostensivos de distinção. Não custa acrescentar que, invariavelmente imbuídos de que "estar encarnado" é sempre uma missão, para eles a estância aqui na Terra em uma situação social superior sempre foi doutrinariamente considerada por eles como algo religiosamente merecido, e merecido por cada um deles nas vidas passadas que levou.

Todos esses aspectos formais de uma expressividade propositalmente enternecedora no relatar fatos nos levaram a não poder dispensar, no exame das biografias - uma das principiais fontes desta pesquisa - o olhar com distanciamento crítico e a consciência permanente da necessidade de pesar e medir, ou seja, de calcular cuidadosamente o teor e o tom das informações nelas apresentadas; biografias que muitas vezes mais parecem hagiografias. Um pequeno exemplo:

Esperando o ensejo de se fixar na instituição venerável [a FEB], que lhe guarda as tradições e continua o seu santificado labor ao lado das criaturas, a célula referida [Grupo Ismael] permanecia com Antônio Luiz Sayão e Bittencourt Sampaio, desde 24 de setembro de 1885, até que Bezerra de Menezes, com os seus grandes sacrifícios e indescritíveis devotamentos, eliminasse as mais sérias divergências e 
aplainasse obstáculos, utilizando as suas inesgotáveis reservas de paciência e de humildade e consolidando a Federação para que se formasse uma organização federativa. Enquanto, lá fora, muitos companheiros da caravana espiritual se deixavam levar por inovações e experiências estranhas aos preceitos evangélicos, o Grupo Ismael esperava uma época de compreensão mais elevada e harmoniosa para o desdobramento de suas preciosas atividades. Todavia, nas lutas pesadas do mundo, Bezerra de Menezes era o impávido desbravador, no seu apostolado de preparação, fraternizando com todos os grupos para conduzi-los, suavemente, à sombra da bandeira do grande emissário de Jesus [o Anjo Ismael]. (IDEM, p. 204)

Um dos mais importantes espíritas do Grupo Ismael, Francisco Leite de Bittencourt Sampaio, filho de um negociante português, nasceu em Laranjeiras, na então província de Sergipe, em 1834. Principiou seus estudos de Direito na Faculdade do Recife, continuando-os na Academia de São Paulo (atual Faculdade de Direito), fazendo parte de uma turma de nomes reconhecidos da política e jurisprudência brasileiras ${ }^{98}$. Bittencourt interrompeu temporariamente o seu curso acadêmico em 1856 para acudir os conterrâneos enfermos por ocasião da epidemia de cólera-morbo. Por esse serviço, o governo imperial lhe ofereceria a condecoração da Ordem da Rosa.

Ainda no período da faculdade, colaborou na revista $O$ Guaianá (1856), dos estudantes de Direito, e em outras publicações literárias de São Paulo, como, por exemplo, em A Legenda, nos Ensinos Literários do Ateneu Paulistano, na Revista Mensal do Ensaio Filosófico Paulistano e no Correio Paulistano. Em 1859, agora já bacharel, Bittencourt Sampaio exerceu durante dois anos a promotoria pública na província de Sergipe, migrando definitivamente, em março de 1861, para a antiga Corte do Rio de Janeiro, onde abriu banca de advogado, freqüentando-a por muitos anos.

${ }^{98}$ Entre outros, estavam: Bento Luís de Oliveira Lisboa, Manoel Alves de Araújo e Eleutério da Silva. 
Militante político, filiou-se ao partido liberal e por ele foi eleito deputado pela sua província à Assembléia Geral Legislativa, nas legislaturas de 1864-1866 e 1867-1870, sendo também nesse último período Presidente do Espírito Santo, nomeado por carta imperial, cargo que exerceu até 1868. Foi então que, em 1870, abraçando as idéias republicanas, desligou-se do partido a que pertencia e tornou-se ardoroso propagandista da República. Nessa qualidade, assinou, ao lado de Quintino Bocaiúva, Saldanha da Gama, Antônio da Silva Neto (espírita já citado neste trabalho), entre outros, o célebre Manifesto Republicano, que tão larga repercussão teve. Como jornalistapolítico, colaborou ativamente em A Reforma, órgão do Partido Liberal da Corte, e em algumas folhas mais, entre elas A República, da qual foi redator ao lado de Aristides Lobo, Alfredo Pinto e Pompílio de Albuquerque, nomes importantes da política brasileira. Mais tarde, em 1873, fundava o Partido Republicano Federal juntamente com outros companheiros.

Proclamada a República, foi comissionado para exercer o cargo de redator dos debates na Assembléia Constituinte em 1890 e passou a ocupar o cargo de diretor e administrador da Biblioteca Nacional do Rio de Janeiro. Além de advogado, jurisconsulto, militante político e jornalista, Bittencourt Sampaio também havia enveredado pela esfera artística, nomeadamente a literatura. Chegou mesmo a ter certo reconhecimento no meio, merecendo a atenção de Sílvio Romero ${ }^{99}$. São dele, entre outras obras: "Flores Silvestres”; "Lamartinianas” (tradução de poesias de Lamartine); “A Bela Sara” (tradução das "Orientais”, de Victor Hugo); “A nau da liberdade” (poema épico); “Cartas de Além Túmulo” (publicadas em O Cruzeiro e na Gazeta da Tarde do Rio de Janeiro); “Nossa Senhora da Piedade” (legenda publicada no Monitor Católico), e "Poemas da Escravidão”, escrito no qual Bittencourt mostra sua posição frente à questão do negro no Brasil.

99 "Em Bittencourt Sampaio, predomina o lirismo local, tradicionalista, campesino, popular. Por este lado é um dos melhores poetas do Brasil; é mais natural e espontâneo do que Dias Carneiro, Trajano Galvão e Bruno Seabra, e é mais elevado e artístico do que Juvenal Galeno. Rivaliza com Joaquim Serra e Melo Morais Filho". WANTUIL (2002, p. 249). 
Como já foi dito, surgida a primeira sociedade espírita no Rio de Janeiro, o Grupo Confúcio, Bittencourt Sampaio dela fizera parte, sendo um de seus primeiros diretores. Ao que tudo indica, fora atraído inicialmente ao espiritismo pelos fenômenos "provocados" pelos espíritos, dedicando-se, assim, aos seus estudos. No entanto, pela análise de sua obra espírita e pela dedicação prestada à propaganda do espiritismo, a sua maior atenção esteve mesmo voltada aos seus aspectos religiosos. Tanto é assim que todos os agrupamentos de que fizera parte tinham como caráter distintivo a relevância dada à interpretação religiosa do espiritismo. Lá, naquela instituição, ficaria conhecido por sua "mediunidade receitista", tratando de muitos doentes com remédios homeopáticos. Já em 1876, quando foi fundada a Sociedade Deus, Cristo e Caridade, Bittencourt Sampaio fizera igualmente parte dela, presidindo-lhe os trabalhos, dos quais fazia parte importante o estudo dos evangelhos à luz de Roustaing. Fundado tempos depois o Grupo Espírita Fraternidade, Bittencourt a ele também emprestou sua colaboração, bem como ao Grupo Ismael, dirigido por seu colega Antônio Luiz Sayão.

Seu trabalho no meio espírita foi tomando contornos cada vez mais nítidos. Para além de estar à frente dessas instituições - posição que, aliás, permitiu-lhe imprimir mais fortemente o caráter religioso ao espiritismo Bittencourt começava a se aventurar também na produção literária espírita. Em 1882, agora já na condição de grande amigo de Bezerra de Menezes, publicava a sua mais conhecida obra espírita, A divina epopéia, uma transformação do Evangelho de João em versos decassílabos, obra que por sinal parece fazer referência à estrutura poética utilizada por Dante Alighieri em A divina comédia. Sua composição poética, ele a completou escrevendo para o volume uma segunda parte, em prosa, na qual cada um dos cantos é explicado à luz do espiritismo, precedidas tais explicações de longa "Prefação", onde se acha explanada a visão espírita da divindade de Jesus. Um trabalho que bem poucos conseguiriam realizar, pelo fato de demandar um montante de capital escolar razoavelmente elevado, justamente por exigir um bom domínio não só da língua portuguesa e mesmo da literatura, mas também de conhecimentos para 
além dos mais vulgares acerca da bíblia e particularmente dos evangelhos domínio que foi sendo adquirido ao longo de sua educação religiosa. É por isso que, no exame dos atores fundadores do espiritismo no Brasil, uma das conclusões que salta aos olhos é a de que, desde suas origens, esse movimento portador de idéias novas esteve sempre atrelado a uma camada letrada socialmente privilegiada.

Não é à toa que ainda hoje se pode apontar como um traço notório dessa religião o elevado grau de escolaridade de seus adeptos. Pois pelo fato mesmo de ser uma religião letrada, uma religião livresca ${ }^{100}$, que se pretende, acima de tudo, racional e positiva, ela exige de seus seguidores um habitus correspondente, um trato maior com as letras e certa familiaridade com um tipo de pensamento mais sutil.

Assim começava seu livro na parte denominada “Advertência”:

O desejo de inocular no espírito e coração de meus filhinhos as santas palavras do Divino Mestre e mostrar-lhes que não se vive tão somente do pão material levou-me nos dias santificados ao estudo dos Evangelhos. [...] Desse estudo, no recolhimento e meditação do gabinete, surgiu a idéia de trasladar para versos heróicos o quarto Evangelho, que foi sempre o da minha particular predileção. (SAMPAIO, 1988, p. 9)

Sua escolha se derivava do fato de que eram justamente os escritos do último evangelho que melhor retratavam "ao vivo a majestosa figura daquele que soube gravar no coração dos séculos as verdades que semeara no Gólgota com o sangue derramado do alto da cruz" (IDEM).

Mas para além dessa figura de Jesus sangrando na cruz tão cara ao catolicismo barroco latino-americano, para Bittencourt estariam precisamente no evangelho de João as referências mais explícitas (as mesmas abraçadas por Roustaing) à natureza espiritual do corpo de Jesus, "o profeta de Nazaré, o filho primogênito de Maria Virgem” (IDEM, p. 11).

${ }^{100}$ Sobre este aspecto do espiritismo, ver LEWGOY (2000). 
Suas condições materiais de vida iriam lhe permitir a realização da tarefa a que se propusera, pois transformar um evangelho inteiro em versos decassílabos não parecia trabalho fácil nem tampouco rápido. O tempo que isso acabou demandando só podia pertencer a alguém cuja situação social positivamente privilegiada estava assegurada. Um trabalho intelectualista voltado muito mais para uma realização pessoal do que propriamente preocupado em aliviar concretamente a penúria material dos mais necessitados, muito embora mais tarde o tenha feito.

Fica-me a satisfação íntima das horas que passei lendo, relendo, anotando e comentando o maior livro que até hoje se tem publicado sobre o Homem-deus do nosso planeta. (IDEM)

Além de ter sido diretor daquelas instituições e de ter trabalhado intelectualmente em prol do espiritismo, Bittencourt Sampaio ficou também conhecido em sua época por seus trabalhos de caridade, sobretudo ao modo espírita, isto é, através dos trabalhos mediúnicos de assistência aos doentes. Foi graças à sua "mediunidade curadora" ou "mediunidade receitista"101 que o Dr. Antônio Luiz Sayão se convertera ao espiritismo religião. Entretanto, sem deixar de lado seu trabalho prático de assistência, Bittencourt continuava dedicando-se simultaneamente à sua produção intelectual em proveito da formulação de um espiritismo cristão. Entrementes, quando se preparava para escrever “A Divina Tragédia do Gólgota, quando fruto maduro, foi colhido pela mão do celeste jardineiro, veio à desencarnação" ${ }^{102}$.

Porém, mesmo depois de sua morte, o "espírito" de Bittencourt Sampaio seguiu - assim como o de Bezerra de Menezes - na labuta espírita. Desse modo, continuou "escrevendo", através do médium Frederico Junior, entre outras, as seguintes obras: "Jesus perante a cristandade" (1898), "De Jesus para as crianças” (1901) e "Do calvário ao apocalipse” (1907), todas publicadas por seu colega Antônio Luiz Sayão.

\footnotetext{
101 Para mais detalhes, ver próximo capítulo.

${ }^{102}$ Reformador, 15 de outubro de 1895.
} 
Do mesmo grupo de Bittencourt e de Bezerra, fazia parte também outro pioneiro do espiritismo religioso no Brasil, o advogado carioca Antônio Luiz Sayão. Espírita desde 1878, foi o responsável pela criação do Grupo dos Humildes ou Grupo do Sayão, entidade criada a partir das discórdias entre científicos e religiosos. Sua conversão ao espiritismo é narrada por ele mesmo em um dos números do Reformador, em formato de carta dirigida ao leitor. Após ter perdido as esperanças quanto à cura de sua esposa, Sayão foi convidado a participar de uma sessão espírita. Em princípio relutara por conta de sua fé católica e também por não acreditar na eficácia da homeopatia, já que daquela sessão iria receber somente medicamentos homeopáticos para a enferma. Assim escreveu:

Meu caro irmão,

[...] Corria o ano de 1878, para mim triste, cheio de aflições e amarguras, que só me dava lenitivo o verter das lágrimas. Eu não cessava de implorar a misericórdia divina [...]. Os sofrimentos de minha mulher, que, mais ou menos, datavam de seis anos, haviam-se agravado ao ponto de seu médico assistente afirmar-me que o termo fatal se aproximava [...]. No dia 11 de Setembro daquele mesmo ano, [...] encontrei-me com o Sr. Cândido de Mendonça, empregado no Foro, que, penalizado de me ver chorando, aconselhou-me que procurasse um meu colega, que, na travessa do Ouvidor, oferecia remédios homeopáticos para as moléstias consideradas incuráveis, com resultados espantosos. Agradecendo-lhe a parte que tomava na minha dor, respondi-lhe que não podia submeter minha mulher ao tratamento de um homem distinto [Bittencourt Sampaio], é verdade, como o conhecia, porém estranho completamente à ciência médica, quando eu tinha os recursos que me podiam oferecer as notabilidades que já a tinham desenganado. O Sr. Cândido de Mendonça, como um enviado da Providência, insistiu [...], quanto mais tratando-se de um homem conhecido, notável e já afamado por curas em casos idênticos; pedindo-me que pelo menos me certificasse dessa verdade para justificação do que me referia. 
Pois bem, no dia seguinte (12 de Setembro de 1878), às onze horas da manhã, compareci à travessa do Ouvidor, onde encontrei aquele colega e mais alguns que o ajudavam, havendo grande número de pessoas, umas recebendo remédios, outros à espera de sua vez, todos alegres e contentes, referindo os milagres das aplicações que fazia com caridade evangélica o homem assaz conhecido, por ser um literato distinto, titulado com carta de Bacharel em Direito, tendo já ocupado os cargos de Presidente de Província, Deputado a Assembléia Geral, porém completa e absolutamente estranho à ciência médica [...]. ${ }^{103}$

Como o próprio Sayão reconhecia à época, as qualidades, isto é, os capitais que revestiam Bittencourt Sampaio foram os fatores mais importantes para a sua decisão de ir à tal sessão e de acreditar que aquelas medicações poderiam surtir algum efeito. Afinal, apesar de nada saber sobre medicina, tinha-se ali um doutor da lei na figura de Sampaio, um político conhecido que tratava de doentes através da homeopatia. Esse fato nos faz novamente reforçar que foram justamente os capitais externos ao domínio religioso, trazidos por médicos, advogados, literatos, políticos, entre outros, que garantiram ao espiritismo o seu fortalecimento e a sua entronização, cada vez mais visível, no campo religioso em formação.

E assim finalizava a sua carta, o seu relato sobre sua conversão e o início do Grupo dos Humildes ou Grupo do Sayão:

Diante de fato tão extraordinário e tão real [...] tomei o firme propósito de só formar juízo depois de estudo sério e refletido. É assim que tratei de estudar com os livros do Mestre, e com muitos outros de menor importância, a Revelação da Revelação sobre os quatro Evangelhos, recebida dos Espíritos e coordenada por Roustaing. Tratei igualmente da verificação prática, trabalhando regularmente, durante dois anos, com médiuns que reuni em uma sala para isto especialmente construída em minha residência [dando origem ao

${ }^{103}$ Reformador, junho de 1891. 
Grupo do Sayão ou Grupo dos Humildes]. Foi nestes trabalhos que verifiquei todas as verdades expendidas na referida obra de J. B. Roustaing [...].

Do vosso humilde irmão, o advogado ANTÔNIO LUIZ SAYÃO. ${ }^{104}$

“Guiado pelo espírito de um frei”, Sayão começava então a sua obra espírita. O que se passou na fase inicial de seu Grupo, ele descreveu minuciosamente em seu primeiro livro intitulado “Trabalhos Espíritas” (1893). Mas foi somente em 1897, com a publicação de "Estudos Evangélicos”, mais tarde reeditado sob o nome de “Elucidações Evangélicas” (1902), que a pena de Sayão passava a colaborar mais efetivamente na construção intelectual do espiritismo como religião.

Servindo posteriormente de base dos estudos do Grupo Ismael e da FEB, sua obra vinha como que para complementar os esforços dos trabalhadores do espiritismo cristão, por isso merecendo destaque nas páginas do Reformador na ocasião de sua publicação:

Altíssima é a missão dos que foram escolhidos para fazerem na Terra a obra de Deus: a divulgação do Evangelho segundo a luz do Espiritismo e dentre aqueles missionários espalhados por toda a Terra, levantaram-se, entre nós, Bittencourt Sampaio, com a sua Divina Epopéia, e Antônio Luiz Sayão, com os seus estudos do Evangelho.

Aquele limitou seu trabalho, que é monumental, ao Evangelho de João. Este ergueu seu monumento sobre os de Mateus, Marcos e Lucas. Um completa o outro [...].

Nenhum saiu dos limites traçados por Roustaing; mas quer um, quer outro, substituíram a longa e difusa explanação daquele autor, por explicações lúcidas e concisas dos textos evangélicos.

104 IDEM. 
Seus trabalhos podem ser ditos: perfeito resumo da interpretação dos Evangelhos em espírito e verdade, segundo Roustaing, corrigido e aumentado em certos pontos, sempre sob a assistência dos Altos Espíritos. ${ }^{105}$

Sua obra mereceria também a atenção de Bezerra de Menezes, este já naquela altura uma sumidade no meio. Tanto é assim que um espírita desconhecido, reconhecendo a posição ocupada por Bezerra, consultou-o como guia seguro a fim de se orientar quanto à validade dos escritos de Sayão em seguida de sua publicação:

Meu caro Max. - A nossa incipiência tem encontrado sempre conforto na vossa palavra inspirada e respeitada mesmo pelos ortodoxos da fé; desde, pois, que assumistes uma tal autoridade, a vossa opinião, sem que a embarace a vossa reconhecida modéstia, é segura orientação para os que entretêm Grupos Espíritas; e, nestas circunstâncias, relevareis que vos peçamos um conselho: podemos tomar os livros publicados pelo Dr. Sayão como normas a seguir no nosso Grupo? - Um discípulo. ${ }^{106}$

Sem mais demoras, respondia Bezerra:

$E$ É, pois, um livro preciso e sagrado o de Roustaing; mas o autor, não possuindo, como homem, a vantagem que faz sobressair o trabalho de Kardec, de clareza e concisão, torna-o bem pouco acessível às inteligências de certo grau para baixo.

Seria obra de meritório valor dar à sua exposição de princípios relevantíssimos a concisão e a clareza que sobram no mestre e que lhe faltam bem sensivelmente.

Foi esta, no fundo, a obra de Sayão.

${ }^{105}$ Reformador, $1^{\circ}$ de fevereiro de 1897.

${ }^{106}$ Gazeta de Notícias, 22 de abril de 1897 (SAYÃO, 1983, p. 35, grifos do autor). 
Em ligeiros traços resumiu, sem lesar, longas exposições - $e$ em linguagem didática clareou e pôs ao alcance de todas as inteligências o que era obscuro à maior parte.

O livro de Sayão é um resumo de Roustaing, com as vantagens de Allan Kardec.

É, portanto, correto e adiantado, sob o ponto de vista doutrinário - e é claro e conciso sob o ponto de vista do método.

Por outra: contém as idéias de Roustaing e o método incomparável de Allan Kardec. (SAYÃO, 1983, p. 36)

E assim, desde o início de sua obra, quando abre a sua apresentação da seguinte forma: "Recebei, meus irmãos, as bênçãos de Jesus, as bênçãos da Virgem Imaculada, Nossa Mãe Santíssima” (IDEM, p. 43), até o seu fim, Sayão não cessou um só instante de fazer referências tanto ao corpo fluídico de Jesus quanto à pureza de Maria:

Era necessário que Jesus se assemelhasse aos homens (exceto em pecado), a fim de que sua morte apresentasse valor idêntico ao da nossa morte e a sua justiça equivalesse à nossa justiça. [...] Era o filho de Deus fazendo-se homem, para que os homens pudessem tornar-se filhos de Deus. [...] Maria, Espírito perfeito, e José, também Espírito perfeito, porém menos elevado que o de Maria, ambos purificados, inferiores, portanto, a Jesus, encarnaram para assistir a este em sua missão. (IDEM, p. 62-63)

A concepção, em Maria, como tudo o mais que a isso se seguiu até ao suposto nascimento do nosso Redentor, tudo considerado uma obra miraculosa, por inexplicável mediante os conhecimentos de então e que inexplicável se conservou até o advento da Terceira Revelação, mais não foi que o resultado de uma ação magneto-espírita, exercida com o emprego de fluidos apropriados. (IDEM, p. 83) 


\section{A "Quarta Revelação"?}

Durante os primeiros anos de sua existência, as teses de Roustaing, surgidas em 1866, não despertaram grande interesse no Brasil. Mesmo Telles de Menezes, tido como o primeiro propagador do espiritismo em terras brasileiras, longe de divulgá-las apenas agradeceu nas páginas d'O Echo d’Álem Túmulo o envio a ele pelo próprio Roustaing de um exemplar, em 1870.

Em princípio, o próprio Kardec também recebera as teorias roustainguistas sem desmerecê-las por completo. Escrevia na Revue Spirite em junho de 1866:

É um trabalho considerável e que tem, para os Espíritas, o mérito de não estar, em nenhum ponto, em contradição com a doutrina ensinada pelo Livro dos Espíritos e o dos Médiuns. As partes correspondentes às que tratamos no Evangelho Segundo o Espiritismo o são em sentido análogo. Aliás, como nos limitamos às máximas morais que, com raras exceções, são claras, estas não poderiam ser interpretadas de diversas maneiras; assim, jamais foram assunto para controvérsias religiosas. ${ }^{107}$

Entretanto, agindo com certa reserva quanto à sua validade, continuou:

Conseqüente com o nosso princípio, que consiste em regular a nossa marcha pelo desenvolvimento da opinião, até nova ordem não daremos as suas teorias nem aprovação nem desaprovação, deixando ao tempo o trabalho de sancioná-las ou as contraditar. Convém, pois,

107 "C'est un travail considérable, et qui a, pour les Spirites, le mérite de n'être sur aucun point en contradiction avec la doctrine enseignée par le Livre des Esprits et celui des Médiums. Les parties correspondantes à celles que nous avons traitées dans l'Evangile selon le Spiritisme le sont dans un sens analogue. Du reste, comme nous nous sommes bornés aux maximes morales qui, à peu d'exceptions près, sont généralement claires, elles ne sauraient être interprétées de diverses manières ; aussi n'ont-elles jamais fait le sujet des controverses religieuses". Revue Spirite, junho de 1866 (tradução nossa). 
considerar essas explicações como opiniões pessoais dos Espíritos que as formularam, opiniões que podem ser justas ou falsas. ${ }^{108}$

Assim, ao final do artigo, quando fez referências mais diretas e explícitas às teses do corpo fluídico de Jesus e ao parto falso de Maria, assuntos-chaves na obra de Roustaing, Kardec demonstrou certa precaução, num tom mais audível:

Sem nos pronunciarmos pró ou contra essa teoria, diremos que ela é, pelo menos, hipotética, e que se um dia fosse reconhecida errada, em falta de base todo o edifício desabaria. ${ }^{109}$

Mas claro ficava que Kardec não havia realmente aprovado as teses, muito embora tivesse de acordo com os ensinamentos morais nelas contidos. Até porque, a obra de Roustaing concorria diretamente com a sua própria obra de codificação ao se auto-reivindicar a "Revelação da Revelação”, pretendendo com isso superar a “Terceira Revelação” - o espiritismo de Allan Kardec.

Passados dois anos, o forte trabalho de estruturação de Kardec parecia chegar ao fim. Vinha à luz aquela que seria a última das cinco obras da codificação, $A$ gênese $e^{110}$. Foi nela, mais precisamente nos capítulos XIV e XV, que Kardec não pouparia esforços para contraditar a teoria de Roustaing e posicionar-se definitivamente quanto ao assunto, pois o que estava em jogo naquela disputa era o monopólio da produção dos bens simbólicos espíritas.

108 "Conséquent avec notre principe, qui consiste à régler notre marche sur le développement de l'opinion, nous ne donnerons, jusqu'à nouvel ordre, à ses théories, ni approbation, ni désapprobation, laissant au temps le soin de les sanctionner ou de les contredire. Il convient donc de considérer ces explications comme des opinions personnelles aux Esprits qui les ont formulées, opinions qui peuvent être justes ou fausses". (IDEM, tradução nossa)

109 "Sans nous prononcer pour ou contre cette théorie, nous dirons qu'elle est au moins hypothétique, et que si un jour elle était reconnue erronée, la base faisant défaut, l'édifice s'écroulerait'. (IDEM, tradução nossa)

110 Obra traduzida não por acaso pelo grupo dos espíritas científicos, totalmente contrários às idéias roustainguistas (ver nota $\mathrm{n} .^{\circ} 80$ ). 
Kardec aspirava, portanto, acabar com as bases para ver desmoronar todo o edifício teórico da pretendida continuadora do seu espiritismo - a obra "rival" Espiritismo cristão ou revelação da revelação. Os quatro evangelhos ${ }^{111}$.

O desaparecimento do corpo de Jesus, depois da sua morte, foi objeto de inúmeros comentários; ele é testado pelos quatro evangelistas, sobre os relatos das mulheres que se apresentaram ao sepulcro no terceiro dia, e ali não o encontraram. Uns viram nesse desaparecimento, um fato milagroso, outros supuseram uma retirada clandestina.

Segundo outra opinião, Jesus não teria revestido um corpo carnal, mas somente um corpo fluídico; não fora, durante a sua vida, senão uma aparição tangível; em uma palavra, uma espécie de agênere. Seu nascimento, sua morte e todos os atos materiais de sua vida, não teriam senão uma aparência. Assim foi que, dizem, seu corpo, voltado ao estado fluídico, pôde desaparecer do sepulcro e com esse mesmo corpo é que ele se teria mostrado depois de sua morte [...]. A questão é, pois, saber se uma tal hipótese é admissível, se é confirmada ou contraditada pelos fatos.

A permanência de Jesus sobre a Terra apresenta dois períodos: o que a precede e aquela que se segue à sua morte. No primeiro, desde o momento da concepção até o nascimento, tudo se passa, na mãe, como nas condições comuns da vida. Desde o seu nascimento até a morte, tudo, em seus atos, em sua linguagem e nas diversas circunstâncias de sua vida, apresenta os caracteres inequívocos da corporeidade. [...] Depois da sua morte, ao contrário, tudo nele revela o ser fluídico. A diferença entre os dois estados é de

${ }^{111}$ Na versão francesa lê-se: Spiritisme Chrétien ou Révélation de la Révélation LES QUATRE ÉVANGILES. Suivis des Commandements expliqués en esprit et en vérité par les évangélistes assistés des apôtres et Moïse. Recueillis et mis en ordre par J.-B. Roustaing. Avocat à la Cour impériale de Bordeaux, ancien bâtonnier. Paris. Librairie Centrale, 24, Boulevard des Italiens. 1866 - Tous droits réservés. Bordeaux, imprimerie Lavertujon, 7, rue des Treilles. 
tal modo marcante que não é possível assimilá-los. (KARDEC, 2001b, p. 309)

Se Jesus, durante a sua vida, nas condições dos seres fluídicos, não teria sentido nem dor, nem nenhuma das necessidades do corpo; supor que assim não haja sido, é tirar-lhe todo o mérito da vida de privações e de sofrimentos que escolheu como exemplo de resignação. Se tudo nele não era senão aparência, todos os atos de sua vida, o anúncio reiterado de sua morte, a cena dolorosa do jardim das Oliveiras, sua prece a Deus para afastar o cálice de seus lábios, sua paixão, sua agonia, tudo, até a sua última exclamação no momento de entregar o Espírito, não teria sido senão um vão simulacro, para enganar sobre a sua natureza e fazer crer num sacrifício ilusório de sua vida, uma comédia indigna de um simples homem honesto, com mais forte razão de um ser superior; em uma palavra, ele teria abusado da boa-fé dos seus contemporâneos e da posteridade. Tais são as conseqüências lógicas desse sistema, conseqüências que não são admissíveis, porque o abaixam moralmente, em lugar de elevá-lo. (IDEM, p. 311)

Embora houvesse existido um diálogo mínimo entre Roustaing e Kardec, a obra roustainguista mal foi conhecida, ou em termos mais precisos, reconhecida no meio espírita francês. Mesmo recebendo uma segunda tiragem em 1882, aumentada somente de um prefácio exclusivamente produzido contra o artigo de Kardec da Revue Spirite, as teses roustainguistas foram pouco ou quase nada difundidas. No entanto, no Brasil, os seus escritos tiveram uma recepção bastante acolhedora, o que favoreceu a sua difusão por parte, sobretudo, do grupo dos religiosos - grupo que tomou cada vez mais a dianteira do movimento espírita brasileiro.

Em 1883 a obra de Roustaing recebia então a sua primeira tradução para o vernáculo. Marechal Francisco Raimundo Ewerton Quadros, seu tradutor, foi um dos primeiros trabalhadores do espiritismo brasileiro e ocupou lugar de justificada saliência no movimento espírita. Ao ser criada a Federação Espírita Brasileira, foi ele eleito seu primeiro presidente, cargo 
que ocupou até 1888, quando cedeu o posto a Bezerra de Menezes, cujo nome havia sido sufragado para esse fim. Também fora ele colaborador indispensável na criação do Reformador, órgão sobre cuja importância para a conformação do espiritismo já deitamos algumas linhas.

Ewerton Quadros nasceu em São Luis, Maranhão, em 17 de outubro de 1841, e faleceu no Rio de Janeiro aos 20 de novembro de 1919. Seu pai, Francisco Raimundo Quadros, também fora militar, mais precisamente Capitão honorário. Órfão de mãe em tenra idade, Ewerton foi criado por sua tia e madrinha de batismo. Fez na terra natal o curso de humanidades e rumou para o Rio de Janeiro em princípios de 1860. Na Corte, fez a Escola Militar, saindo de lá em 1864 como alferes e, em seguida, formou-se em engenharia pela Escola Central da Corte (atual Escola Politécnica), tomando grau de Bacharel em Ciências Físicas e Matemáticas em 1874. Anos mais tarde, fora condecorado pelo governo de Deodoro da Fonseca com a Ordem de Avis, no grau de Oficial, e durante a revolta de 1893-1894, constituiu-se num dos auxiliares diretos do Marechal Floriano Peixoto, tendo sido comandante-emchefe das forças em operações em algumas regiões do país.

Espírita desde 1872, logo começou a colaborar na propaganda do espiritismo através de sua mediunidade, tendo sido também um dos fundadores no Rio de Janeiro do Grupo Espírita Humildade e Fraternidade (1881), desdobramento do Grupo Espírita Fraternidade. Seus primeiros escritos espíritas saíram publicados nos meses de agosto e setembro de 1881 na Revista da Sociedade Acadêmica Deus, Cristo e Caridade. Era um estudo sobre "O magnetismo na criação". Seguiu-se a este, em fevereiro do ano seguinte, uma poesia de sua autoria intitulada “O redivivo”. E em seu número de julho de 1882, a referida revista estampava em suas páginas uma obra poética recebida através de sua mediunidade; intitulava-se "Morrer é deixar a ilusão pela verdade”, assinada com as iniciais $A$. $A$.

Em sua atuação como espírita, Ewerton Quadros realizou algumas conferências no salão da Guarda Velha, enfileirando-se entre os primeiros 
construtores do espiritismo brasileiro através do ciclo de conferências públicas patrocinadas pela FEB - conferências já mencionadas neste trabalho. São de sua lavra também: "História dos povos da antiguidade até a vinda do messias", escrita sob o ponto de vista espírita-roustanguista; “Os astros”, estudos da criação do mundo; conferência sobre "O espiritismo, seu lugar na classificação das ciências"; "As manifestações do sentimento religioso através dos tempos”; "Catecismo espírita dedicado às meninas", um trabalho rigorosamente doutrinário que também reproduz a narrativa roustainguista. Traduziu muitos artigos bem como obras do francês e do inglês, sobressaindo entre estas últimas "O fenômeno espírita", de Gabriel Delanne, e "Bases científicas do espiritismo”, de Epes Sargent.

Ao que tudo indica, teria sido Ewerton Quadros, pelo menos no princípio de sua atuação no meio espírita, um espírita científico. Publicou suas primeiras obras na Revista da Sociedade Acadêmica, mais pendentes para o caráter científico, e também traduziu obras tidas como científicas para esse movimento. No entanto, foi seu o trabalho de trazer à língua portuguesa uma das obras mais bem acolhidas pelos espíritas religiosos, caso que pode nos indicar um certo trânsito dos agentes em litígio entre os diferentes modos de ser espírita ou mesmo uma certa indefinição de parte deles de como adotar o espiritismo.

Como dito anteriormente, o conhecimento de outras línguas foi fator importante no modo de conformação do espiritismo no Brasil. Esse saber dava àquele que o possuía um poder bastante significativo de ditar ou divulgar determinadas obras em detrimento de outras, adicionando ou omitindo, de acordo com as suas predisposições, obras dos grupos espíritas de outros países, ajudando a delinear a construção do espiritismo brasileiro. Nessa toada é que surgia a tradução para o português da obra de J.-B. Roustaing feita por Quadros, tarefa iniciada em 1883. Entretanto, somente quinze anos mais tarde, em 15 de janeiro de 1898, quando o grupo religioso já dominava o movimento espírita, ela começaria a ser publicada no Reformador em formato de 
fascículo, sob os auspícios de ninguém menos que Bezerra de Menezes. Essa seriação, todavia, seria interrompida tempos mais tarde por ocasião de sua $1^{\mathrm{a}}$ edição no ano de 1909.

Mas a divulgação da obra roustainguista mais significativa em termos de edição estava ainda por vir. Em 1920 a Federação Espírita Brasileira lançava uma nova tradução dos quatro volumes de Os quatro evangelhos, tradução feita por Guillon Ribeiro, presidente da FEB de 1920 a 1921 e de 1930 a 1943.

Nascido no Estado do Maranhão, em janeiro de 1875, filho de pais pobres e logo órfão de pai aos sete anos, Luiz Olímpio Guillon Ribeiro ingressou gratuitamente no Seminário de São Luís, onde fez os primeiros estudos. Após a morte do pai, foi com a mãe e os irmãos para o Rio de Janeiro. Lá, à noite, trabalhava como redator no Jornal do Comércio para complementar os recursos da família. Mas apesar de vir de uma família humilde, acabou chegando ao Senado Federal, no cargo de Diretor Geral da Secretaria do Senado, desempenhando naquela casa trabalho que mereceu inclusive um discurso elogioso de Rui Barbosa ${ }^{112}$.

Embora pouco conhecido no meio espírita atual, traduziu quase todos os livros de Allan Kardec, além da sua mais divulgada tradução, a de Roustaing, com toda uma estrutura de índices criada por ele mesmo para facilitar o acesso ao conteúdo dessa obra. Quando da sua $2^{\mathrm{a}}$ edição, em 1942, o próprio Guillon confessou ter sido aquele o mais importante trabalho de sua vida, tendo durado cinco anos:

${ }^{112}$ Em seu discurso pronunciado na sessão de 14 de outubro de 1903, referindo-se ao trabalho de Guillon Ribeiro de revisão do projeto do Código Civil, Rui Barbosa dizia: "Devo, entretanto, Sr. Presidente, desempenhar-me de um dever de consciência - registrar e agradecer da tribuna do Senado a colaboração preciosa do Sr. Doutor Guillon Ribeiro, que me acompanhou nesse trabalho com a maior inteligência, não limitando os seus serviços à parte material do comum dos revisores, mas, muitas vezes suprindo até a desatenções e negligências minhas". In: Anais do Senado Federal, vol. II, p. 717 (Sessões de $1^{\circ}$ de agosto a 31 de outubro de 1903). 
[...] pois que essa tradução, porventura, o trabalho de maior importância que me foi dado realizar como espírita, aquele que me faculta de não considerar de todo inútil a minha existência de obreiro da Seara da Verdade, nem baldados todos os esforços que hei conjugado dos de quantos, espiritualmente melhor aparelhados para a tarefa de tão alta monta, se têm consagrado a demonstrar que o Espiritismo ressurge, em todo o fulgor da pureza originária o Cristianismo do Cristo, o excelso Filho de Deus, que jamais houve de sofrer o sepultamento da carne putrescível. (ANJOS, 1993, p. 98)

A lista de livros traduzidos por Guillon é mesmo grande. Nela destacam-se as traduções de “A grande síntese” (de Pietro Ubaldi), “Joanna d’Arc, médium” e “O além e a sobrevivência do ser” (ambos de Léon Denis) e “A crise da morte”, “Animismo e espiritismo”, “Xenoglossia” e "Psicologia e espiritismo” (todos os quatro de Ernesto Bozzano). Além de todo esse trabalho, Guillon Ribeiro ainda escreveu seus próprios livros: “Jesus, nem Deus nem homem”, “Espiritismo e política”, “A mulher” e “A Federação Espírita Brasileira”. Outros trabalhos seus são as seguintes compilações: “Trabalhos no Grupo Ismael” (3 volumes), “Ensinamentos do além” e “Advertência do aquém”. Também foram publicadas diversas matérias suas no Reformador e na imprensa espírita em geral.

Desde o final do século XIX, os espíritas da FEB já vinham cogitando a idéia de montar uma oficina tipográfica não só para a impressão do periódico Reformador, mas também para a impressão das “obras de propaganda”. Passavam-se os anos e a idéia era acalentada e adiada por falta de recursos. Foi então que Guillon Ribeiro, agora na liderança da FEB, reviveu o projeto e transformou-o em realidade. Passando por todos os cargos da direção dessa instituição, inclusive o de diretor do Reformador, foi Guillon quem mais importância teve para a divulgação do livro espírita e para a ampliação da imprensa espírita no Brasil. Por isso compreende-se tamanha atividade editorial, desde suas traduções até as produções próprias, e mesmo o incentivo à produção espírita de outros autores, posto que passou a ter sob seu domínio, 
após tê-lo estruturado, todo um aparelho destinado à divulgação, disseminação e vulgarização das idéias espíritas. Foi em sua gestão que começaram a ser editados os famosos livros de Francisco Cândido Xavier.

Mas por que a obra de Roustaing foi tão propagada aqui no Brasil no meio espírita religioso? Por que teve ela importância essencial na fundamentação e na conformação do espiritismo, esse que dizemos hoje oficial, apesar de Allan Kardec tê-la desqualificado? Por que, finalmente, embora tenha provocado dissensões no meio espírita, ela se adaptou tão bem à realidade do espiritismo daqui?

\section{Um novo tipo de religiosidade}

Em todo momento da constituição do espiritismo religião, a necessidade religiosa de seus portadores assumiu determinadas características bastante significativas do ponto de vista sociológico. Desde 1) a orquestração de um tipo de salvação específica, que passa pela transformação qualitativa de um ethos espírita (pensado aqui como esquemas implícitos de ação e de apreciação) em uma ética kardecista (um conjunto sistematizado e racionalizado de normas explícitas), passando pela 2) utilização de um linguajar característico e pela produção de narrativas exageradamente emotivas, de tendências sentimentais e edificantes, até por fim chegar na 3) disseminação de um vocabulário próprio e na construção de instituições e órgãos de difusão e vulgarização do espiritismo. Todo esse processo fez parte de um trabalho intelectual condicionado pelas predisposições de um racionalismo proveniente da situação prática da vida de seus agentes. Em grau mais amplo, o destino do espiritismo foi condicionado pelo caminho que tomou particularmente o grupo religioso nesse processo, e pelas relações deste com os demais grupos e com os constrangimentos externos ao movimento espírita. Foram essas circunstâncias que levaram à formação de uma corporação de "literatos" espíritas, em virtude da necessidade de 1) criar os escritos “sagrados”, 2) interpretá-los e 3) impor o seu uso "correto". 
Pensando dessa forma, o que pretendemos enfocar a partir de agora não será mais a produção literária com suas características e conteúdos próprios, mas sim o caráter específico assumido pelo tipo de religiosidade que nasceu em virtude da particularidade da camada intelectual que influiu sobre ela. A um grupo de agentes de fins do século XIX que provinha exclusivamente de uma camada socialmente privilegiada e letrada, correspondeu a criação de uma peculiar ética religiosa. Composto em sua maioria por profissionais liberais (advogados, médicos, jornalistas e professores), ou pelo menos dirigido por pessoas procedentes dessa camada, esse grupo foi o responsável pelo trabalho de sistematização e de organização que converteu um sistema de esquemas implícitos em um sistema racionalizado de normas explícitas. Em conseqüência de um trabalho não-calculado, conciliaram algumas concepções católicas com outras espíritas, misturando-se a isso alguns postulados científicos em voga à época. Inicialmente subterrâneas, suas tendências alcançaram a construção de um determinado tipo de espiritismo que contribuiu - e ainda contribui - sobremaneira para a conformação de um modo de ser espírita (e até mesmo de ser católico) no Brasil.

O grupo que configurou o espiritismo no Brasil como espiritismo religião revela alguns pequenos contrastes. Havia aqueles que faziam parte, como é o caso dos médicos, advogados e militares de alta patente, seja das camadas privilegiadas superiores, seja das camadas privilegiadas estamentalmente inferiores à aristocracia, como também havia aqueles que faziam parte das camadas não muito privilegiadas (mas que não chegavam a ser negativamente privilegiadas), composta de funcionários públicos, jornalistas e professores. Mas para além dessas pequenas diferenças, existia outra característica que nos possibilita entendê-los como um grupo mais ou menos homogêneo: eram intelectuais, gente que gostava de ler e escrever.

O fato de na estrutura de classes os primeiros promoters do espiritismo estarem inseridos numa camada instruída, sendo este o mais forte traço de aproximação entre eles e fator importante para entender a aproximação de cada 
um deles com o espiritismo, há um outro traço comum que não se pode esquecer, um outro aspecto de sua trajetória de vida: a maior parte dos agentes até agora analisados consiste de indivíduos que, saindo de sua terra natal e deixando para trás o lar paterno - geralmente provenientes do Norte e Nordeste do país -, rumaram para a capital do País, o Rio de Janeiro, a fim de prosseguir nos estudos ou trabalhar.

Longe da terra natal e avançando sempre mais em escolaridade, encontravam nos agrupamentos espíritas a possibilidade de compartilhar uma religiosidade com ares de moderna, por seu racionalismo ético e filo-científico, sem necessariamente ter que deixar de lado algumas das crenças católicas inculcadas em seus tenros anos de formação. É nesse sentido que se pode olhar para os primeiros portadores e propagadores do espiritismo, não como representantes de sua profissão ou vetores de interesses de classe materiais, mas como portadores ideológicos de um novo ethos, que eles chamarão de espírita, o qual se enlaçava a eles com tanto mais facilidade quanto mais eticamente elaborado se tornava por suas próprias mãos de médicos e escritores.

Na medida em que se trata aqui daquilo que em termos weberianos se pode chamar de um "intelectualismo-pária”, a intensidade do trabalho assumido por esses primeiros espíritas deve-se ao fato de, situados num meio social propício, terem podido angariar capitais importantes, para não dizer imprescindíveis, para a realização de sua obra, o cumprimento de sua missão espírita, fosse aplicando seus conhecimentos dos mecanismos da imprensa de difusão de idéias, fosse financiando materialmente as instituições que criavam, fosse ainda revertendo seu traquejo intelectual e seu gosto intelectualista em prol da armação de uma doutrina religiosa. O ambiente que na Capital Federal se criava em torno do espiritismo nascente mostrou-se, como se pode constatar por esta pesquisa, inteiramente favorável ao seu trabalho intelectual; um trabalho que foi se tornando cada vez mais religioso, assumindo cada vez mais 
uma orientação religiosa. Porque era assim que se tornava, também, cada vez mais reconhecido.

Capazes de tomar posições novas sem deixar completamente de lado as originárias, vertiam as suas obras para uma linguagem progressivamente mais sacralizada. Buscaram, portanto, desenvolver a faceta do espiritismo que mais lhes agradava e pouco a pouco foram criando a partir dela uma doutrina sistematizada, um conjunto de regras e preceitos de ordem valorativa e moral; diríamos mesmo uma doutrina espírita brasileira.

É nesse sentido que podemos entender a boa recepção que teve a obra de Roustaing aqui no Brasil. Contendo um lado religioso bastante forte, ela afinar-se-ia perfeitamente com o habitus dos espíritas, também eles religiosos. Claro que nem todos os espíritas religiosos se tornaram adeptos de suas idéias, mas grande parte dos que aceitaram as teses roustainguistas foram os que, criados em um catolicismo bastante arraigado e não conseguindo ou não querendo dele se afastar totalmente, encontraram nessas teses uma explicação espírita bastante católica, se assim podemos dizer. Quanto àqueles que pertenciam às alas filosófica e científica do espiritismo, apesar de também provenientes de uma mesma formação católica, como não o enxergavam exclusivamente enquanto religião, seria difícil realizarem tal associação e abraçar um espiritismo roustainguista.

As afinidades entre a doutrina espírita e o catolicismo se davam em vários sentidos nas teses de Roustaing, permanecendo seus crentes em certo sentido ainda católicos. Em primeiro lugar porque esses espíritas não deixavam de acreditar em um dos preceitos mais católicos: a virgindade de Maria. Ao adotar a tese de que Jesus teria tido um corpo fluídico, ou seja, de que não teria nascido de um parto normal, os espíritas roustainguistas mantinham de uma forma que lhes parecia inteiramente racional a crença na virgindade de Maria. Dessa maneira, também conseguiam mesclar idéias em voga à época sobre a existência e a ação de “fluidos magnéticos" (idéias adotadas por todos os espíritas) com a pureza moral e carnal da mãe de Jesus. Este, por sua vez, 
passava a ser tratado como uma espécie de semideus, homem-deus, cujo corpo, de outra essência, fugia às leis naturais.

Em segundo lugar porque adotavam a "teoria da queda", de acordo com a qual os homens, ao terem se afastado do "verdadeiro caminho", como repisa o velho simbolismo de Adão e Eva, mergulharam num período de sofrimentos e expiações, experimentados, sobretudo, pelas criaturas “encarnadas". O corpo passa a sofrer dores por culpa da "queda” original ${ }^{113}$ (ou do "pecado original”, no linguajar católico), donde a necessidade das várias reencarnações para superá-la; e se assim não fosse, seria difícil acreditar na bondade e justiça divinas, que obrigariam a um ser sem culpa, como foi Jesus, a receber sofrimentos imerecidos destinados somente àqueles que são feitos de carne.

Dessa maneira, o termo fluídico, adjetivando o corpo de Jesus, explicava, de um lado, a virgindade de Maria, de outro, continuava dando sentido à teoria da queda, e, além disso, apresentava - como terceira característica semelhante ao catolicismo - o corpo como algo maculado, sujo, o oposto da pureza de Jesus; ele não poderia, portanto, de forma alguma sofrer dores como os "encarnados", muito menos passar pelas privações e pelas necessidades da carne, esta sim de caráter bastante chão. E ao mesmo tempo, era exatamente este adjetivo, fluídico, que permitia realizar a ligação entre as teses de Roustaing e as de Kardec, já que para este último, todo ser humano possui “fluidos magnéticos” ou magnetismo, uma espécie de energia.

Allan Kardec entendia o homem "encarnado" composto de três elementos: o espírito, o corpo material e o corpo espiritual, denominado perispírito. Este sim seria uma espécie de corpo fluídico com as mesmas

${ }^{113}$ Em sua extensa obra de 24 volumes, toda ela centrada na "queda espiritual", o italiano Pietro Ubaldi vinha complementar no século XX o que coube a Roustaing introduzir no pensamento espírita brasileiro no século XIX. Não foi à toa que Guillon Ribeiro, presidente da FEB durante 14 anos, além de ter traduzido a obra toda de Roustaing, também seria o responsável pela tradução dos livros de Pietro Ubaldi. 
características fisionômicas do corpo carnal, mas que serviria como uma espécie de invólucro mais etéreo do espírito. Após a morte do corpo, seria somente o perispírito que continuaria revestindo o espírito. Ou seja, existia também na concepção kardequiana a noção de um corpo fluídico, mas este só servindo enquanto roupagem do espírito dos "desencarnados”, nunca sendo tangível a ponto de se confundir com o corpo material.

É por isso tudo que a obra de Roustaing parecia irretocável, pois conciliava as predisposições católicas daqueles agentes com as novas idéias da época. Mesclavam-se perfeitamente nela alguns dogmas católicos com outros espíritas, resultando disso o espiritismo religioso adotado pelo grupo que esteve à frente da Federação Espírita Brasileira em fins do século XIX; um espiritismo bastante católico, ou dependendo do ponto de vista, um catolicismo bastante espírita, que até hoje deita as suas raízes. Conciliar algumas crenças e dogmas espíritas com os dogmas e a liturgia católica; acreditar na reencarnação e no "pecado original”; freqüentar os centros espíritas e acreditar na virgindade de Maria; parecia, ou melhor, ainda parece uma solução sem maiores conflitos, bem aceita e freqüentemente encontrada no campo da religiosidade brasileira. Como se vê, o cordão umbilical da religiosidade espírita continuou ainda amarrado ao catolicismo. Pois apesar dos esforços dos intelectuais espíritas de criarem uma nova posição no campo religioso, investindo pesado em tal realização, mantiveram nela muito daquilo que já era tido como legítimo e consagrado no campo das crenças religiosas no Brasil.

É importante frisar aqui que existiram sim outros agrupamentos espíritas que também davam proeminência aos aspectos morais do espiritismo sem, no entanto, adotarem as teses roustainguistas, preferindo, assim, permanecer mais fiéis à obra de Kardec. Aliás, o embate que mais mobilizou os agrupamentos religiosos - luta que existe ainda hoje - estava ligado exatamente à questão da adesão ou não às teses. Contudo, quando ajustamos o nosso foco com maior precisão sobre os personagens que mais pesadamente investiram no trabalho de produção simbólica espírita, saltam-nos aos olhos as 
atividades de um grupo em especial; um grupo que foi se tornando o mais legítimo no sentido de ter tido mais força para ditar o que era e o que não era espiritismo, pelo menos naquele momento. Desse modo, demasiadamente influenciadas pelas obras de Roustaing, encontramos nas obras dos espíritas do Grupo Ismael definições bastante precisas sobre aquilo em que acreditavam, elaboravam e transmitiam aos demais, isto é, aquilo que foi o espiritismo legítimo à época.

Para nós, Jesus é o nosso Deus, mas o Deus no sentido do Salmo 81 por ele mesmo citado. Não o reconhecemos como o Ente Supremo, o Criador incriado, nem tampouco como um homem, um ser mortal, sujeito como nós às necessidades da matéria. Temo-lo simplesmente como um Espírito com a forma humana, aparente corpo fluídico - embora visível e tangível a todos e em relação imediata com o Criador do universo. (SAMPAIO, 1988, p. 182)

Como espírito puríssimo e sem mácula desde séculos e séculos, era-lhe impossível encarnar em um corpo tão grosseiro como o nosso, porque, desligado completamente da matéria, seu perispírito não poderia sujeitar-se à semelhante prisão [...].

Jesus, portanto, não teve um corpo material como o nosso, não encarnou no ventre da Virgem Maria; teve apenas a forma humana aparente, necessária e indispensável ao cumprimento de sua missão na terra. (IDEM, p. 198)

Mas isso não quer dizer em absoluto que pelo fato de terem abraçado essas teses tivessem deixado completamente de lado as obras da codificação de Allan Kardec. Pelo contrário, elas continuaram sendo a fonte de inspiração do espiritismo cristão brasileiro, mesmo daquele, com tendências católicas. As crenças na sucessiva reencarnação e na denominada Lei de Ação e Reação, além de outras noções kardequianas já mencionadas anteriormente, sempre estiveram presentes no espiritismo brasileiro desde os seus primeiros passos no Brasil. 
Com o estabelecimento e o fortalecimento do grupo religioso no poder da FEB, esta instituição passou a tomar contornos cada vez mais nítidos, afirmando e reafirmando progressivamente os preceitos evangélicos decorrentes da moral cristã. Assim, se os líderes espíritas, de um lado, aderiram às idéias roustainguistas, elevando os evangelhos ao nível mais sagrado, de outro, também fizeram das idéias de Kardec o seu sustentáculo, e entre elas, como já havia salientado o próprio Kardec, destacaram uma regra moral em particular: a caridade. Dessa maneira, a ênfase era dada e condensada em duas grandes consignas: "Deus, Cristo e Caridade” e "Fora da caridade não há salvação", marcas bem específicas e caras aos grupos espíritas religiosos, sobretudo ao Grupo Ismael e à Federação Espírita Brasileira. Muito embora existissem outros lemas com o mesmo propósito de serem reconhecidos, tais como as tríades "Deus, Amor e Liberdade" (divisa do grupo científico), ou mesmo a de Kardec, "Trabalho, Solidariedade e Tolerância” (que mal foi difundida no Brasil), foi mesmo a bandeira "Deus, Cristo e Caridade" a vitoriosa nessa guerra, a que conseguiu ser fincada em solo brasileiro.

Agora, com um sistema teórico-doutrinário que se tornava cada vez mais elaborado, foram surgindo tipos especificamente espíritas de comportamento, sendo que o "especificamente" cada vez mais queria dizer “religiosamente” espíritas. 


\begin{tabular}{||l||}
\hline \multicolumn{1}{|c||}{$\mathbf{1}^{\text {a }}$ Fase: Rio de Janeiro (RJ) } \\
Courrier du Brésil: Casimir Lieutaud \\
(professor e jornalista) - precursor do \\
espiritismo no Brasil
\end{tabular}

$2^{\mathrm{a}}$ Fase: Salvador - Bahia

Grupo Familiar do Espiritismo (1865): Telles de Menezes (jornalista e professor) primeiro grupo oficial espírita

Grupo Confúcio (1873):

\section{$3^{\mathrm{a}}$ Fase: Rio de Janeiro (RJ)}

Antonio da Silva Neta (engenheiro):

- $\quad$ autor de livros editados pela Editora Garnier;

- fundador da Revista Espírita (1875)

Joaquim Carlos Travassos (médico):

- primeiro tradutor de quatro dos cinco "livros da codificação” pela Editora Garnier;

- $\quad$ amigo de Bezerra de Menezes e responsável por introduzir este último no espiritismo.

Casimir Lieutaud (professor e jornalista):

- precursor do espiritismo no Brasil e autor da primeira obra espírita publicada no Brasil: Les temps sont arrivés

Bittencourt Sampaio (advogado, literato e jornalista):

- $\quad$ editor da Editora Garnier

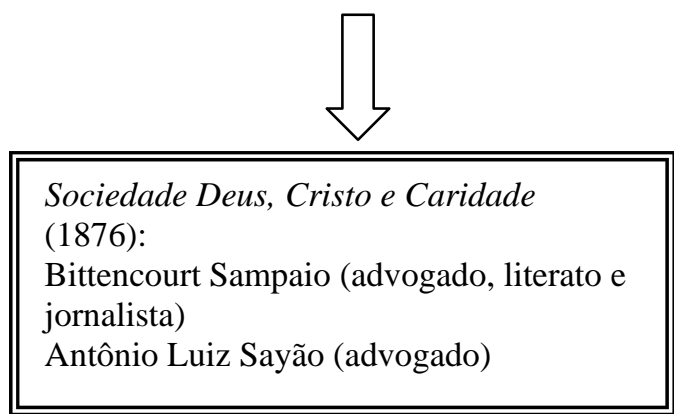

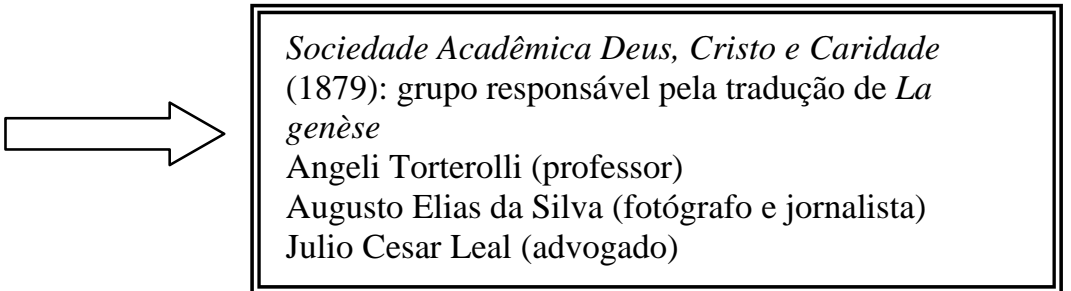

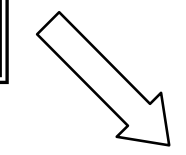

Grupo Espírita Fraternidade (1880):

Antônio Luiz Sayão (advogado)

Frederico da Silva Junior (funcionário público)

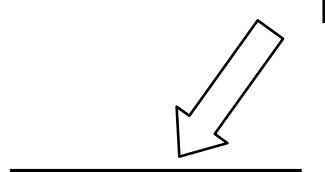

Sociedade Psicológica (1881)

Federação Espírita Brasileira (1884):

Eweton Quadros (militar)

Bezerra de Menezes (médico)

Bittencourt Sampaio (advogado e literato)

Antônio Luiz Sayão (advogado)

Augusto Elias (fotógrafo):

- $\quad$ Fundador do Reformador (1883)

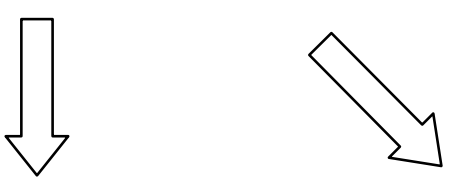

Centro Espírita Humildade e

Fraternidade (1881):

Ewerton Quadros (militar) primeiro tradutor de J.-B. Roustaing

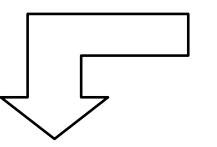

$$
\text { Fre }
$$$$
\text { Frederico da Silva Junior }
$$$$
\text { (funcionário público) }
$$

Bezerra de Menezes (médico)

Grupo Ismael ou Grupo do Sayão ou Grupo dos Humildes (1880):

Antônio Luiz Sayão

(advogado)

Bittencourt Sampaio

(advogado e literato)

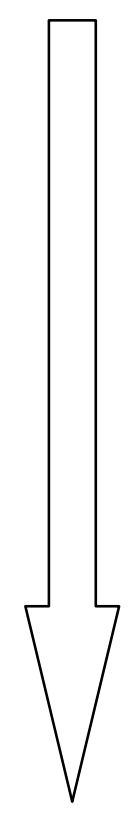

Centro da União Espírita do Brasil (1881)

- órgão federativo criado a partir do congresso realizado pela Sociedade Acadêmica Deus, Cristo e Caridade: Angeli Torterolli (professor) 


\section{Capítulo IV - "Fora da caridade não há salvação"}

\section{Os estudos espíritas}

Partindo do pressuposto weberiano de que o interesse religioso tem por princípio a necessidade de teodicéia, isto é, de uma racionalização teórica voltada para a validação discursiva das propriedades e carências não só materiais, mas também simbólicas, associadas a um tipo determinado de condição de existência e de posição na estrutura social, dependendo da posição social que um grupo de indivíduos ocupar, a promessa religiosa mais apta a satisfazer seu interesse religioso será aquela que, segundo uma leitura bourdieusiana, mais afinidades tiver com seu sistema de disposições já existentes. No caso em exame, fossem doutores da lei, fossem doutores do corpo, fossem jornalistas, fossem professores, tratava-se de um grupo social letrado, instruído, fortemente influenciado pelas idéias positivistas e universalistas da época, que encontrou no espiritismo um modo de pensamento potencialmente capaz de lhes fornecer um sistema de justificação plausível das propriedades que lhes estavam objetivamente associadas por sua condição social.

No final do Oitocentos brasileiro, o espiritismo se apresentava ao grupo em questão como um corpo doutrinário cuja apelo moral — “Espíritas: amai-vos, eis o primeiro ensinamento; instruí-vos, eis o segundo” (KARDEC, 2000, p. 101) — lhes permitia tirar conseqüências práticas de ação no mundo na vida presente com vistas à próxima. Por outro lado, esse tipo de ação no mundo se mostrava condizente ao estilo de vida já praticado na camada social de que provinham os primeiros a se tornarem seus adeptos, principalmente no tocante à aposta feita na instrução como uma forma de salvação. Isto é: na aquisição de um corpo de conhecimentos alcançados especialmente através da leitura, da erudição, do contato com os livros, o espírita encontrava uma ação 
no mundo bastante similar ao habitus próprio de uma camada letrada socialmente em ascensão, justamente aquela que se tornaria a camada social portadora [Träger] do espiritismo posteriormente alcunhado de “mesa branca”. Mesmo havendo passado mais de um século, até hoje se vê no espiritismo que sua camada portadora continua sendo a mais letrada — ou pelo menos a que possui grau mais elevado de escolaridade - em comparação com o resto da população brasileira. São homologias que persistem no tempo.

A valorização dos estudos, da educação formal e da cultura letrada encontrável naquela camada passava a receber uma validação a mais na harmonia quase miraculosa que se observava a partir de então entre a forma em que se revestiam as práticas sociais e as crenças religiosas. Ocorria, portanto, uma justificação religiosa ajustada a uma prática social corrente, prática que agora, sob uma mesma forma, encontrava um novo conteúdo no âmbito em que passava a atuar, isto é, no âmbito da expressão religiosa na vida daqueles agentes. Para realizar essa transferência de significados, o trabalho intelectual religioso entrou em ação; noutras palavras, um trabalho de reinterpretação, de re-tradução, isto é, de conversão de natureza, pode-se dizer, de um estilo de vida para uma ética religiosa, um conjunto sistematizado de regras e de normas.

Seguindo esta perspectiva, todos os agrupamentos espíritas orientados por Bezerra de Menezes - o grande nomóteta do espiritismo - deveriam sempre reservar uma parte de suas sessões ao estudo da doutrina espírita especificamente, mas principalmente dos evangelhos. Era por essa razão que Bezerra de Menezes, enumerando as diretrizes organizacionais de um “legítimo” centro espírita, ditava em 1896:

1) O VALOR AOS ESTUDOS: os grupos não podem dar um passo sem o conhecimento da doutrina; donde a obrigação, para todos, de dedicarem, sempre, uma parte de suas sessões àquele estudo. Um grupo que não conhece nem se preocupa com o estudo da doutrina pode ser tudo, menos um grupo espírita. ${ }^{114}$

${ }^{114}$ Reformador, 15 de fevereiro de 1896. 
Daí se entende melhor o trabalho intelectual dos primeiros espíritas, a sua produtividade em termos de publicação, o seu empenho em escrever, os elevados investimentos de tempo aplicados em prol do espiritismo, de sua elaboração e de sua divulgação. Pois o que estava em jogo aí era a busca de salvação através do trabalho intelectual, da busca de conhecimento, da instrução. Assim, a elaboração de uma concepção de salvação que traz consigo esse tipo de conseqüências para o comportamento prático dos indivíduos, para a sua condução de vida, era em grande medida a própria projeção no campo religioso da sombra de suas posições sociais.

Ainda no plano de organização ditado por Bezerra de Menezes, lê-se no segundo e terceiro tópicos:

2) CARIDADE: a orientação característica do espiritismo, temo-lo dito à sociedade, é a compreensão e a divulgação do Evangelho interpretado à luz da nova revelação; donde a obrigação dos grupos que abraçam aquela orientação e, por isso constituem-se membros da verdadeira família espírita, de tão depressa conhecerem a doutrina, aplicarem-se à luz desta ao estudo do Evangelho. A caridade raciocinada deve existir no coração do espírita e, pois, é obrigação dos grupos exercê-la para com seus irmãos do espaço, que aí sofreram as conseqüências de suas faltas. Devem, portanto, dedicar uma parte de seus trabalhos a este piedoso serviço. Uma parte para o estudo e outra para a prática do espiritismo ou do Evangelho.

3) JESUS E OS GUIAS: quer numa parte [os estudos], quer noutra [a caridade], porém, é de lei, para que colham bons frutos, que estejam todos concentrados, com todo respeito e humildade, invocando a proteção do guia do grupo e, principalmente, do chefe da família espírita, o divino Jesus. ${ }^{115}$

A concepção de salvação espírita também acarretou outras ações no mundo social, já que ela transcorre intimamente dentro deste mundo; uma

115 IDEM. 
salvação enquanto obra pessoal a ser alcançada com a ajuda indireta, mas sempre presente, dos “poderes dos espíritos”. Tem-se, assim, a possibilidade de salvação cumprindo-se os dois preceitos: “amai-vos e instruí-vos”. Mas o “amai-vos” toma um caráter bastante peculiar no espiritismo, pois não é simplesmente o amor acósmico, indistinto. Este preceito manifestava-se (e ainda se manifesta com tamanha força) sob uma forma bastante realçada pela doutrina espírita que são as “obras de caridade”.

À altura de Bezerra de Menezes, a exaltação desta virtude - a caridade, isto é, um benefício prestado a outrem - foi tomando corpo e tornando-se uma espécie de traço marcante do espiritismo, assumindo várias formas: 1) desde auxílios materiais e amparo social (exercidos sobretudo no "Serviço de Assistência aos Necessitados”, uma organização que funcionava nas dependências da FEB), passando pelos 2) trabalhos de assistência espiritual, desenvolvidos através dos “passes” ou das consultas homeopáticas, até chegar 3) aos trabalhos de “desobsessão”, em que o papel do médium e do doutrinador eram indispensáveis. Como uma das formas de salvação, talvez a mais importante, porque a mais destacada e trabalhada no espiritismo desde seus inícios com Allan Kardec, mas recebendo no Brasil, país de desamparados aos milhões e de toda sorte, uma acentuação ainda mais pronunciada, a caridade foi posta como pedra de toque no arcabouço teórico-doutrinário espírita. A incorporação dessa virtude como meio salvífico acarretou duas principais conseqüências sobre os adeptos do espiritismo: de um lado, as intervenções práticas no meio social, de outro, um tipo especial de organização burocráticoinstitucional. A apropriação subjetiva do sistema de pensamento espírita sob esse arranjo peculiar que tomou a doutrina pode ser tida como um indício para melhor compreender por que o espiritismo hoje é uma religião cujo destaque recai sobretudo em suas inúmeras obras filantrópicas - uma das características que a distinguem no campo religioso brasileiro.

O que geralmente se tem hoje no espiritismo, do ponto de vista organizacional, e que decorre diretamente da visão de mundo espírita, é um 
conjunto de instituições entrelaçadas: o centro espírita, enquanto unidade elementar, consiste no lugar privilegiado para a prática dos estudos e para a execução prática da doutrina; lá, as formas de caridade mais praticadas são a “assistência espiritual” e os trabalhos de “desobsessão”. Quase sempre funcionam, atreladas aos centros, instituições de auxílio social e material, freqüentemente creches, escolas profissionalizantes, albergues, orfanatos, hospitais e asilos ${ }^{116}$. Há ainda as federações, que procuram, através de diversos mecanismos (organismos e publicações), fornecer orientações e recomendações que garantam certa uniformidade em termos doutrinários e práticos.

Apresentada ao mesmo tempo como um valor pessoal, um ideal social e uma lei divina, a caridade enquanto meio de salvação pressupunha e envolvia a parte necessitada, proveniente geralmente de uma camada negativamente privilegiada, oposta ou pelo menos distante da camada que aderiu ao espiritismo. Desse modo, a salvação espírita do indivíduo, ou a sua evolução, não podia ser entendida separadamente da condição material de vida daqueles que o cercavam. Segundo a soteriologia espírita, em última análise, as camadas positivamente privilegiadas necessitavam das camadas negativamente privilegiadas para a sua salvação, uma salvação que no limite não projetava em seu horizonte a certeza de uma sociedade materialmente igualitária neste mundo, já que previa a assistência aos mais pobres principalmente como meio de progressão espiritual dos seus seguidores ${ }^{117}$. É também verdade, por outro

${ }^{116}$ Sobre o assunto, ver GIUMBELLI (1998).
${ }^{117}$ Pululam trechos e recomendações no Evangelho segundo o espiritismo que discorrem sobre o assunto. A título de exemplo, citamos estas passagens que dizem: "Amemo-nos uns aos outros e façamos aos outros o que queríamos que nos fosse feito. Toda a religião, toda a moral, se encerram nestes dois preceitos. Não haveria ódios nem ressentimentos. Direi mais ainda: não haveria pobreza, porque, do supérfluo da mesa de cada rico, quantos pobres seriam alimentados!" (KARDEC, 2000, p. 174); ou esta: "Todos vós podeis dar: a qualquer classe a que pertençais, tereis sempre alguma coisa que pode ser dividida. Seja o que for que Deus vos tenha dado, deveis uma parcela aos que nem sequer têm o necessário, pois em seu lugar ficaríeis contentes, se alguém dividisse convosco. 
lado, que havia igualmente a noção de que o assistido era antes de tudo um indivíduo com os mesmos direitos e deveres que concernem a todos; um "próximo que deve ser amado como se ama a si mesmo". Era assim que a doutrina espírita, tal como formulada em seus começos, continha apenas tímidos ideais igualitários. À sombra disso é que se pode entender por que a camada portadora do espiritismo no Brasil em seus momentos iniciais logo se apegou a ele, porque ela mesma já vinha também se entrelaçando aos ideais universalistas de sua época, tais como o abolicionismo e o republicanismo como dito em outra ocasião. Os ideais espíritas encontraram, dessa maneira, um terreno propício para a sua frutificação na camada que os abraçou; era a confluência de denominadores comuns entre dois sistemas de pensamento aparentemente análogos, ou pelo menos entendidos pelos espíritas enquanto tal.

Por outra parte, a caridade também aparecia vinculada ao auxílio espiritual em suas mais variadas modalidades tipicamente espíritas ("passes", “águas fluidificadas”, “desobsessão”, “doutrinação” entre outras), sobre as quais falaremos daqui a pouco.

É sob esse prisma que podemos compreender que no espiritismo as boas obras religiosamente qualificadas e socialmente orientadas são, pois, consideradas meios de salvação. Ponderadas numa contabilidade exata entre a culpa e o mérito de cada ação, as boas obras, de acordo com o resultado desse cálculo de conta corrente, atribuem ao indivíduo seu destino religioso. Portanto, pensar que as obras assistenciais espíritas foram desenvolvidas apenas como formas de proteção contra as injunções externas ao movimento espírita, como querem alguns estudiosos ${ }^{118}$, é negar a existência de todo um sistema de crenças espíritas religiosamente orientado, em cuja criação deve-se levar em conta todo um trabalho intelectual de sistematização.

Vossos tesouros da terra diminuirão um pouco, mas vossos tesouros do céu serão mais abundantes [...]" (IDEM, p. 183).

${ }^{118}$ Assunto já tratado no Capítulo II, mais precisamente no sub-capítulo intitulado $O$ "Allan Kardec brasileiro" e o que é Espiritismo. 


\section{A "Assistência aos Necessitados"}

- Ismael - disse-lhe o Senhor - concentraremos agora todos os nossos esforços [...]. Procurarás entre todas as agremiações da doutrina, aquela que possa reunir no seu seio todos os agrupamentos; colocarás aí a tua célula, a fim de que todas as mentalidades postas na direção dos trabalhos evangélicos estejam afinadas pelo diapasão da tua serenidade $e$ do teu devotamento à minha seara. E como as atividades humanas constituem, em todos os tempos, um oceano de inquietudes, a caridade pura deverá ser a âncora da tua obra [...]. A caridade valerá mais que todas as ciências e filosofias, no transcurso das eras, e será com ela que conseguirás consolidar a tua Casa e a tua obra. (XAVIER, 1982, 220-221)

Era assim que o “Anjo Ismael”, tido pelos espíritas como emissário direto de Jesus e protetor do Brasil - diga-se de passagem, concepções bastante similares às católicas de anjo que intermedeia relações com Deus e espíritos protetores que mais parecem santos padroeiros - escolhia a Federação Espírita Brasileira como a instituição mais bem preparada para assentar as bases da sua doutrina de caridade. E nela consolidaria o "Serviço de Assistência aos Necessitados”, uma organização prestadora de auxílios materiais, sociais e espirituais, cerne dos serviços cristãos da FEB. Esse aspecto filantrópico da “Assistência”, que não tinha personalidade jurídica e vivia sob o mesmo teto da Federação, emprestava a essa instituição enorme prestígio. Esse discurso mítico, é bom relembrar, foi elaborado décadas depois como forma de consagrar a história da instituição, conforme dito anteriormente ${ }^{119}$.

Embora revestida de sacralidade, a criação, em 1890, dessa organização nas dependências da FEB não ficou incólume a ataques externos do mundo social, já que se tornara um centro chamariz das atenções. Fundado na gestão de Dias da Cruz (1890-1894), o "Serviço de Assistência aos Necessitados” era apontado como grande problema tanto pelos católicos, cuja animosidade crescia à medida que o espiritismo se firmava por se afirmar como

\footnotetext{
${ }^{119}$ Ver Capítulo III, sub-capítulo A matriz do espiritismo religião.
} 
religião, quanto pelos médicos alopatas, interessados no monopólio da cura, recebendo, ainda, interferências policiais, uma vez que as práticas religiosas exercidas pelos médiuns transgrediam artigos do Código Penal.

O exercício de caridade lá prestado em forma de atendimento tanto à "saúde do espírito quanto à saúde do corpo" era parte fundamental da organização. Médiuns e médicos diplomados prescreviam remédios homeopáticos, "águas fluidificadas" e "tratamentos de passe”. Os médiuns, indivíduos geralmente sem diploma de medicina, denominados precisamente como "médiuns receitistas" ou "médiuns curadores" - como foi o caso de Bittencourt Sampaio - receitavam, através da ajuda de seus "espíritos-guias", medicamentos homeopáticos aos doentes, fossem do corpo, fossem do espírito. Mas apesar de observada e combatida, a “Assistência aos Necessitados”, isto é, a prática da caridade ao estilo espírita, era a grande arma na luta pela propagação do espiritismo, pois foi ela uma das principais responsáveis pela notoriedade que o espiritismo passou a usufruir ${ }^{120}$.

Por volta de 1900, as instalações seriam visitadas por João do Rio, pseudônimo do jornalista Paulo Barreto, como parte de uma série de reportagens para a Gazeta de Notícias publicadas sob o nome de "As Religiões no Rio”. Interessado em mapear as diversas manifestações religiosas na então capital da República brasileira, João do Rio transcreveu nelas os vários casos de cura relatados por pessoas com as quais conversou na FEB, ajudando, sem o saber, a propagar a existência desse serviço para meios mais amplos.

Personagem também conhecido no mundo homeopático, o então presidente da FEB e criador da "Assistência aos Necessitados", Francisco de Menezes Dias da Cruz, nasceu na cidade do Rio de Janeiro em 1853 e foi nela que se formou médico. Diretor do Reformador durante a sua presidência período de ampliação formal e de expansão do periódico que passou a ter emissários de outros estados do Brasil -, escreveu nele inúmeros artigos doutrinários com a assinatura modesta de "Um Espírita”. Foi ele quem primeiro

${ }^{120}$ Sobre o assunto, ver DAMAZIO (1994). 
tentou, em 1891, adquirir um prédio próprio para a FEB e montar uma oficina tipográfica para a impressão do referido periódico e de obras espíritas em geral. Sua história mescla-se muito com a história da homeopatia ${ }^{121}$ no Brasil. Num panorama geral sobre sua atuação no meio homeopático, é possível entrever que uma das variantes importantes da consolidação dessa forma de medicina em terras brasileiras correspondeu exatamente aos esforços despendidos por ele. Em 1900, por exemplo, o Dr. Dias da Cruz ressuscitava o "Instituto Hahnemaniano do Brasil”, que havia sido criado em 1879 pelo médico homeopata do Império, o Dr. Saturnino Soares de Meireles. Primeiro sob sua vice-presidência e depois sob sua presidência, Dias da Cruz trabalhou bastante em prol da homeopatia. Fez reaparecer em 1901 os "Anais da Medicina Homeopática”, cuja publicação havia sido interrompida em 1884; deles foi redator durante alguns anos, empenhando-se na defesa da homeopatia, polemizando inclusive com o Dr. Nuno de Andrade, diretor geral de Saúde Pública, médico alopata e acirrado inimigo da homeopatia. Dias da Cruz colaboraria também na organização dos programas de ensino do novo estabelecimento, a recém-fundada Faculdade Hahnemaniana (1912), na qual lecionou. Quando da inauguração do Hospital Hahnemaniano, em 1916, discursou em nome do Instituto. Foi presidente do $1^{\circ}$ Congresso Brasileiro de Homeopatia. Propagandista dos mais convictos e autorizados, reconhecido no meio por sua atuação, foi ele, por mais de meio século, um dos marcos da homeopatia brasileira, sendo também um dos responsáveis, entre outros, pela convergência entre espiritismo e homeopatia no Brasil.

Outros espíritas, médicos ou não, como Bezerra de Menezes e Bittencourt Sampaio, também adotaram a homeopatia, considerando-a $o$ método terapêutico mais adequado para o espiritismo. Isso porque havia entre esses dois sistemas de pensamento elementos comuns a partir dos quais lhes foi

121 Método terapêutico criado pelo médico alemão Christian Friedrich Samuel Hahnemenn (1755-1843) cujo princípio está baseado na similia similibus curantur ("os semelhantes curam-se pelos semelhantes"). 
possível realizar, ainda que de forma não consciente, algumas analogias entre as concepções espíritas e as bases da homeopatia.

A característica fundamental dessa medicina, aquilo mesmo que a define, consiste no emprego de medicamentos segundo o princípio de semelhança, também chamado de lei de similitude; em outras palavras, o paciente deve inserir em seu corpo aquilo mesmo que o faz estar doente. Esta característica é responsável pela sua própria denominação, pois o prefixo homo significa semelhante e o radical patia quer dizer doença, lembrando ainda que o prefixo grego alo expressa aquilo que é outro, um outro, diferente. Entretanto, para que o medicamento não sobrepusesse seus efeitos aos da própria enfermidade, ele deveria ser submetido a uma diluição e agitação, de maneira a ser empregado em doses mínimas e infinitesimais. Deste modo, a substância perderia todo e qualquer efeito tóxico e passaria a agir estimulando o organismo a reagir contra a sua própria enfermidade. Poderíamos, pois, considerar que a homeopatia, nesse sentido, agiria dentro dos princípios de ação e reação, estimulando o organismo a reagir contra o seu próprio mal. Assim, os adeptos da homeopatia, incluindo os adeptos espíritas, consideravam o medicamento homeopático como uma forma de energia, uma espécie de fluido, tal o grau de diluição em que se encontrava. Partindo então dessa noção comum, outras afinidades possíveis vinham a reboque; semelhanças funcionais que caminhavam paralelamente entre os dois sistemas de pensamento.

É por isto que quanto mais alta for a dinamização, o que quer dizer mais apurado o fluido, maior é o efeito sobre o organismo. [...] Não é a substância que cura, mas sim o fluido que nela se contem; $e$ este, quanto mais depurado, quanto mais eterizado, melhor é recebido, mais assimilado e, portanto, mais atua sobre o organismo doente. Estudem a terapêutica [homeopática] por este prisma e descobrirão maravilhas. ${ }^{122}$

${ }^{122}$ Excerto extraído do artigo: Razão das doses infinitesimais. Reformador, $1^{\circ}$ de agosto de 1897. 
O doente na homeopatia, por exemplo, era visto como uma unidade, como um todo indivisível, de modo que o motivo do tratamento homeopático passaria a ser ele e não as suas doenças isoladamente, considerando o todo mente/corpo na sua propensão a adoecer. A homeopatia pressupunha a necessidade de tratar o campo no qual a doença se desenvolveu, ou seja, as predisposições mórbidas do indivíduo. Esse princípio homeopático fundamentava-se na existência de um organismo imaterial sustentando o substrato físico, que a homeopatia chamava de energia vital, onde se esconderiam os desequilíbrios provenientes da mente, fonte primária de todas as enfermidades.

Era aqui que residiam três pontos de vista semelhantes ao modo espírita de conceber o homem e suas doenças. O primeiro referia-se ao "organismo imaterial” da homeopatia, que no espiritismo recebia equivalência na concepção de perispírito, corpo fluídico que revestia o espírito. O segundo, por sua vez, tratava-se da concepção homeopática de "mente", residência última dos desequilíbrios, encerrada no sistema espírita pela da idéia de espírito. O terceiro elemento análogo consistia na noção de "energia”, cujo equivalente espírita seria a noção de fluido, ponto central sobre o qual teria se debruçado inicialmente a ciência bastante em voga e designada à época de magnetismo. De acordo com os espíritas, o espiritismo viria a ser o seu sucessor nesses estudos.

É neste ponto que podemos visualizar a dívida que o espiritismo teve para com a teoria do magnetismo. Partindo de seus pressupostos e ao pretender se fundamentar cientificamente segundo os parâmetros dessa teoria, o espiritismo desde Allan Kardec almejou ir mais além, pois asseverava dar conta de explicar fatos que esta ciência não o fazia. Incorporando em seu arcabouço teórico noções do magnetismo, o espiritismo tornava-se capaz de dar conta de um fator que lhe era fundamental: as relações entre o mundo visível e o mundo invisível. Daí a apropriação da categoria "fluido" e seu uso para explicar, entre outros fatores, 1) o tipo material que compõe o perispírito (uma espécie de 
corpo fluídico); 2) os fenômenos espíritas de comunicação e de movimentação dos objetos, que nada mais seriam do que o resultado de manipulações de fluidos realizadas pelos espíritos, e 3) os mecanismos do "passe”, um tipo de "magnetização" coadjuvada por um espírito.

Os fluidos constituir-se-iam então, de acordo com a doutrina espírita, em um tipo mais etéreo de matéria ao mesmo tempo em que uma forma de energia, denominada "fluido espiritual". Possuindo qualidades diferentes, eles poderiam ser bons ou maus, isto é, benéficos (os mais eterizados) ou maléficos (os mais densos). Seguindo essa mesma concepção, o perispírito seria de natureza idêntica à dos fluidos espirituais, assimilando-os com facilidade, como uma esponja quando se embebe de um líquido. Esses fluidos exerceriam sobre o perispírito uma ação tanto mais direta, quanto, por sua expansão e sua irradiação, o perispírito com eles se confundisse. Atuando esses fluidos sobre o perispírito, este, a seu turno, teria a capacidade de reagir sobre o organismo material - o corpo - com o qual se acharia em contato direto. Assim, concluíam os espíritas: se os fluidos fossem de boa natureza, o corpo ressentiria uma impressão salutar; se fossem maus, a impressão seria penosa; se fossem permanentes e enérgicos, os fluidos maus poderiam ocasionar desordens físicas, não sendo outra, portanto, a causa das doenças para os espíritas. Mas se os fluidos podiam causar desordens que chegavam freqüentemente a ameaçar a saúde do corpo, eles também eram capazes, por outro lado, quando benéficos, de proporcionar o alívio das enfermidades (KARDEC, 2001b, Cap. XIV).

Nesse sentido, o "passe”, isto é, a imposição das mãos sobre uma pessoa com a intenção de aliviar dores e sofrimentos físicos ou espirituais, curá-la de algum mal, ou simplesmente fortalecê-la, nada mais era do que uma transmissão de bons fluidos - método utilizado nos centros espíritas já desde Bezerra de Menezes (e mesmo de Allan Kardec), ganhando destaque na “Assistência aos Necessitados". Consistir-se-ia, portanto, numa espécie de manipulação, por parte dos "passistas” (médiuns que administravam o passe), dos fluidos benéficos emanados dos "espíritos auxiliares" em benefício do 
“paciente”. Era assim que do mesmo modo que o homem, através de seu perispírito, poderia absorver os maus fluidos tornando-se enfermo, ele poderia também, através do passe, assimilar os bons fluidos e se restabelecer. O mesmo acontecia no caso das prescrições dos médiuns "receitistas”. Os medicamentos homeopáticos eram compostos no fundo por uma sorte de fluido que curaria tanto o corpo quanto o espírito, elementos que, juntamente com o perispírito, formariam o homem “encarnado”.

Precisando o nosso olhar sobre toda essa construção teórica espírita, principalmente no que se refere às peculiaridades do caso brasileiro - que tende a enfocar suas preocupações na questão da cura ${ }^{123}$, daí suas ligações com a homeopatia -, podemos ao mesmo tempo observar e compreender um ponto crucial da concepção espírita e que em muito influenciou as ações práticas de seus adeptos: a assistência espiritual confundia-se com assistência material, já que para o espiritismo corpo e espírito, intermediados pelo perispírito, comporiam uma só unidade e tão-somente enquanto tal deveria ser tratada.

Guiados por uma concepção de mundo criada e elaborada por agentes investidos nesse processo, as ações dos espíritas, sobretudo dos médiuns, acabaram acarretando conseqüências indesejadas contrárias às suas práticas num momento específico de sua história. O papel desempenhado pelos médiuns espíritas, "passistas” ou "receitistas”, no sentido de oferecerem a cura, fosse do corpo, fosse do espírito, dos que a eles se achegavam, foi o propósito que mais se chocou, de um lado, contra os interesses dos médicos de então, sedentos do monopólio da cura, e, de outro, contra as forças policiais, preocupadas em cumprir o Código Penal. Esse embate, que muita atenção já chamou dos pesquisadores acadêmicos ${ }^{124}$, tornou-se o ponto mais candente da história do espiritismo no Brasil, podendo também ser perfeitamente explicado a partir do

\footnotetext{
${ }^{123}$ Sobre este assunto, ver DAMAZIO (1994).

${ }^{124}$ No caso do espiritismo: GIUMBELLI (1997a, 1997b); HESS, (1987b); MAGGIE
} (1986, 1992); SCHRTZMEYER (2004); WARREN (1984, 1986). No caso similar da umbanda: BROWN (1985); NEGRÃO (1996a); ORTIZ (1988). 
ponto de vista do especificamente religioso. Isso equivale a dizer que as ações espíritas postas em prática no mundo e que nada mais significavam do que a oferta de salvação da alma podem ser compreendidas quando se compreende o sistema de motivações e de crenças que as sustentava e justificava.

Ao contrário do que muitos pesquisadores afirmam (MAGGIE, 1986, 1992; GIUMBELLI, 1997a, 1997b; SCHRTZMEYER, 2004), o espiritismo não foi formado, seja como um rótulo, seja como uma religião, apenas segundo as injunções externas pelas quais se viu obrigado a passar naquele momento específico do Brasil de fins do século XIX e início do XX. Houve uma guerra simbólica na qual contenderam várias vertentes de interpretação do espiritismo, todas com a mesma finalidade: ter para si o poder legítimo de ditar o que era ou não espiritismo. Longe de ser uma estratégia de defesa contra as pressões externas, a criação de um espiritismo religioso foi o resultado de pesados investimentos. Foi preciso muito trabalho religioso para organizá-lo, sistematizá-lo e, principalmente, inculcá-lo na vida de seus adeptos. Por isso, não se pode entender sua formação peculiar no Brasil, ou a formação das fronteiras demarcadoras de sua identidade, como se o espiritismo tivesse sido emoldurado somente por discursos ou forças externas a ele; como se a decisão de se tornar uma religião, e uma religião cristã que adota práticas de prestação de auxílio gratuito, fosse tomada apenas para escapar ileso ao Código Penal ou como forma de poder atuar sem maiores pressões dos demais campos.

Claro está, por outro lado, que essas pressões de uma forma ou de outra acabaram por interferir no modo de agir do espiritismo brasileiro tempos depois, já que ele se viu tolhido em suas possibilidades de atuação. Entretanto, enxergá-lo em sua formação como sendo tão-somente o resultado de pressões externas de outros campos - médico, jurídico, científico - é mais uma vez menosprezar uma análise interna dos móveis de ação que impulsionaram (e continuam impulsionando) os agentes envolvidos. 


\section{A Escola de Médiuns}

Construído de maneira a ter a caridade como um dos principais meios de salvação e tendo como característica doutrinária fundamental a concepção de que as enfermidades do corpo são ou estão estreitamente ligadas às enfermidades do espírito, o espiritismo assim orquestrado não poderia agir de outra forma a não ser atuando no sentido de oferecer a cura aos doentes de todas as ordens, conseqüência inevitável de sua visão de mundo. Segundo este ponto de vista, espiritismo e ciência médica se complementavam, e se assim não fosse seria difícil entender as atividades espíritas tão preocupadas com o restabelecimento físico do "próximo”. A mediunidade “receitista” se manifestava como numa espécie de adoção pelas práticas espíritas de elementos consagrados na medicina, sempre de acordo com a cosmovisão da doutrina. Com efeito, tanto num quanto noutro sistema de pensamento havia elementos análogos tais como: o doente e aquele que o cura ou auxilia; a enfermidade, a consulta e o seu tratamento; o alívio dos sintomas e os medicamentos. Porém, no espiritismo religioso, tudo isso se passava como se fosse no reino do religioso, recebendo esses elementos uma significação diferenciada. Talvez pelo grande número de intelectuais espíritas formados em medicina, as práticas que já eram correntes entre eles tomaram um novo sentido quando implantadas na doutrina. Este fator pode ter influenciado fortemente na criação de um espiritismo introjetado de elementos do meio médico e por isso bastante preocupado com a cura dos enfermos, não importando se do corpo ou do espírito - práticas que provavelmente abriram um campo propício para atuação, tempos mais tarde, das denominadas “cirurgias espíritas” ou “operações espirituais” ${ }^{125}$. Ocorria então um processo de mudança de

${ }^{125}$ Na década de 1950, José Pedro de Freitas (1921-1971), denominado também pelo vulgo de Zé Arigó, ficou conhecido pelas suas "proezas mediúnicas", primeiro em Minas Gerais, depois em todo o Brasil. Afirmando receber a orientação de um médico "desencarnado" chamado Dr. Fritz, Arigó realizava por intermédio de suas faculdades mediúnicas "operações espirituais" ou "cirurgias espíritas". "Incorporado", isto é, orientado 
significado e de direção: de práticas médicas para práticas da mediunidade “receitista”, que por sua vez começaram a ser vistas como um exercício de apostolado e de salvação no campo religioso. Mas essa transmutação de sentido nada mais era do que a consagração de um comportamento adquirido, pela formação profissional, de alguns dos agentes portadores do espiritismo; uma forma de conciliar uma visão religiosa de mundo com as predisposições dos agentes que a abraçaram. Esse fator não se esgota enquanto explicação única da característica peculiar que tomou o espiritismo, mas não deixa de ser emblemático do ponto de vista do número de médicos que se tornaram espíritas e que investiram fortemente na legitimação do espiritismo no campo religioso brasileiro $^{126}$.

pelo tal espírito, Arigó utilizava-se de facas e canivetes para extrair em rápidos procedimentos, quistos e tumores. As incisões eram pequenas, se comparadas aos procedimentos cirúrgicos praticados à época, muitas vezes menores que o material por elas extraído. Por vezes, durante a intervenção, Arigó ditava receitas aos pacientes para complementar o "tratamento". Essas práticas se espandiram tempos depois, havendo outros médiuns que igualmente afirmavam receber orientações desse ou mesmo de outros "médicos do espaço".

${ }^{126}$ Embora não seja o nosso objetivo neste trabalho, arriscamos uma interpretação condizente com o nosso ponto de vista analítico - a respeito dos motivos pelos quais os espíritas sofreram menos perseguições do que os umdandistas anos mais tarde, no momento da constituição desta religião (primeiras décadas do século $X X$ ). Preocupados também em prestar auxílios às enfermidades tanto do corpo quanto do espírito (sendo talvez esta uma das principais características fundamentais do campo religioso brasileiro: o aspecto taumatúrgico), os umbandistas criaram e desenvolveram práticas e ações específicas nesse sentido. Entretanto, não possuindo o mesmo respaldo social que o espiritismo - respaldo proveniente da presença de intelectuais de classe média em postos de direção - e tendo se apropriado de práticas, rituais e concepções considerados inferiores à época porque procedentes de ritos africanos, a umbanda foi logo taxada de "baixo espiritismo" e inferiorizada no seu campo de atuação. Mesmo cooptando para si uma denominação que se tornava cada vez mais legítima no campo em questão, isto é, a denominação espiritismo, a umbanda não conseguiria atingir o mesmo status que alcançou o espiritismo de um Dr. Bezerra de Menezes, por exemplo. Não tendo desde o seu início o mesmo peso legitimador que teve o espiritismo, ou o "alto espiritismo", ela se viu obrigada a passar por maiores constrangimentos externos, o que não quer dizer, por outro lado, que ela tenha se formado ou se limitado unicamente através dessas pressões. O número de intelectuais e de livros 
De caso pensado, pudemos, pois, lançar-nos na compreensão da história do espiritismo não propriamente a partir das instituições sociais objetivas que foram sendo construídas com o início do campo religioso brasileiro, nem tampouco a partir do próprio processo político repressor que ajudou a impulsionar a sua criação, mas sim dos efeitos que a apropriação subjetiva de um sistema de pensamento estava talhada a suscitar na conduta de vida dos agentes no campo. Porque o que levamos em consideração nesse tipo de análise são as relações nas quais um certo tipo de visão de mundo influencia as ações e a vida material daqueles que lhe são adeptos, a ponto de criar um “mundo” relativamente autônomo com regras próprias e dinâmica específica.

Tendo, portanto, papel fundamental na prática da caridade e no alastramento do conhecimento da doutrina para além do círculo espírita, o médium, independentemente de sua especificidade, era peça-chave para a realização desse processo. E não só no campo de atuação da mediunidade “passista” ou "receitista” podiam a caridade e o médium atuar; eles também o faziam no processo designado pelo termo “desobsessão”. Também ela um ato de caridade, a desobsessão significava, no sentido amplo da palavra, a ação de curar alguém da obsessão, espécie de enfermidade do espírito, que levaria freqüentemente o obsedado à loucura ${ }^{127}$. A obsessão seria, portanto, “o domínio que alguns espíritos logram adquirir sobre certas pessoas. Nunca é praticado senão por espíritos inferiores que procuram dominar” (KARDEC, 1998, cap.

sobre a umbanda, e as disputas internas desse segmento em busca da primazia do discurso umbandista não nos deixam concluir que ela tenha sido tão-somente algo organizado e sistematizado de fora para dentro. Aliás, uma das variáveis que explicam a sua formatação (e mesmo as configurações por que foi passando o espiritismo nas primeiras décadas do século $X X)$ provém justamente dos diálogos que os intelectuais umbandistas travaram tanto com os intelectuais espíritas quanto com os intelectuais católicos, diálogos que por sua vez foram dando corpo e lógica própria ao campo religioso brasileiro, criando, assim, o nosso pluralismo religioso.

127 Bezerra de Menezes dedicou especial atenção aos processos denominados "obsessivos", chegando a escrever um livro sobre isso, intitulado A Loucura sob novo prisma. Sobre a terapia espírita a partir desse ponto de vista, ver WARREN (1984). 
XXIII, item 232). A cura da obsessão, uma cura de caráter marcadamente espiritual, basear-se-ia na "conscientização" do enfermo e do espírito agressor através da "doutrinação", que consistia no diálogo entre o doutrinador e os envolvidos no processo: o espírito obsessor, que se manifestaria através de um médium, e o obsedado, cujo declínio moral o teria levado à obsessão; este, por sua vez, nada mais seria, no fundo, do que um médium também ele, não obstante "deseducado", porque teria se deixado levar pelas influências maléficas dos espíritos. Daí a necessidade de sua "educação” ao mesmo tempo “mediúnica” e moral, isto é, espírita.

Por todos esses fatores, não era sem razão que Bezerra de Menezes propôs, em 1890, no interregno de suas presidências, a criação de uma "Escola de Médiuns”. Motivado pelas “comunicações” de ninguém menos que Allan Kardec, recebidas pelo médium Frederico Pereira da Silva Junior (do Grupo Ismael), na qual dizia:

Mas para a propaganda precisamos dos elementos constitutivos dela. Pergunto: - onde a Escola de Médiuns? Existe? [...] Ou a vossa propaganda se limita tão somente a falar do Espiritismo? (ABREU, 1996a, p. 112)

Bezerra logo percebeu a necessidade da instalação de uma organização que ao fim e ao cabo tornar-se-ia capaz de formar os próprios "sacerdotes" espíritas, necessários e responsáveis pela propaganda do espiritismo em terras brasileiras. Embora no início essa sua proposta não tenha sido totalmente aceita por todos os seus companheiros, anos mais tarde receberia ela o incentivo de muitos, tendo hoje a "escola de médiuns" espaço obrigatório em todos os centros espíritas. E assim continuava enumerando e ditando as suas diretrizes:

6) MEDIUNIDADE: A chave do estudo e da prática do espiritismo é o médium, que deve ser moralizado em sua vida privada, conhecedor da doutrina, especialmente do Livro dos Médiuns, e bem desenvolvido no trabalho. 
Também por isto, os grupos devem, em sessão, trabalhar no desenvolvimento das mediunidades dos seus membros. ${ }^{128}$

Mas para além da formação de "sacerdotes", garantia do fortalecimento da propagação do espiritismo, o que também estava (e ainda está) por detrás da criação de uma escola de médiuns é a busca de um método de salvação capaz de produzir o auto-aperfeiçoamento. Além da instrução e das boas obras, o desenvolvimento da mediunidade aparecia como mais um meio de salvação espírita; uma mediunidade que deveria ser tanto mais “educada” quanto mais importante se tornava para a disseminação do espiritismo. Para produzi-la de modo a se distinguir propositalmente dos êxtases das religiosidades indígenas e afro-brasileiras, um método planejado era caminho certo e indispensável. Assim, em busca de diferenciação frente a essas manifestações, as formas mais polidas, mais cultivadas, mais instruídas e mais suaves de comunicação com o “além” pareciam garantir com maior segurança aos médiuns e, conseqüentemente, ao espiritismo a posse permanente de um estado distintivo perante as demais manifestações similares do campo - uma espécie de projeção no campo religioso da sombra da posição social da camada portadora do espiritismo. Produzindo uma relação de sentido com o mundo e correspondendo qualitativamente às valorações de uma ética religiosa espírita, a mediunidade “consciente e educadamente” praticada inseria-se no processo crescente de racionalização e de sistematização dos bens de salvação espíritas, processo que buscava eliminar a contradição entre um hábito religioso cotidiano e o extra-cotidiano.

No interesse da conscientização da posse religiosa, a experiência de uma religiosidade baseada num método de salvação sistemático só existiu porque existia também a diversidade da qualificação religiosa das pessoas. Segundo o espiritismo, apesar de se manifestar de forma mais ou menos ostensiva em todos os indivíduos, a mediunidade poderia se apresentar de várias maneiras, classificadas de acordo com o modo pelo qual os médiuns

${ }^{128}$ Reformador, 15 de fevereiro de 1896. 
transmitem as mensagens dos espíritos - classificação exaustivamente trabalhada no Livro dos Médiuns, de Allan Kardec. Havia, portanto, além dos médiuns “passistas” e “receitistas”, ambos também denominados “curadores”, os médiuns “psicógrafos”, que são os que recebem mensagens escritas dos espíritos; os médiuns “psicofônicos” ou médiuns “falantes”, que transmitem as mensagens oralmente; os médiuns “videntes”, que conseguem ver os espíritos e o "mundo de lá”; os médiuns “pictóricos”, que pintam ou desenham obras de arte; médiuns "auditivos”, que ouvem as mensagens e depois as emitem; médiuns de "pressentimento" ou “intuitivos”, que podem entrever ou sentir os acontecimentos futuros; médiuns "sonambúlicos”, que transmitem as mensagens em estado de dormência; médiuns de “efeitos físicos”, que têm a capacidade de mover objetos à distância, entre outras modalidades.

Com o desenvolvimento de um espiritismo que se conformava cada vez mais como uma doutrina religiosa - processo perseguido principalmente pelo grupo de intelectuais espíritas roustainguistas, que se estabeleceu na direção da FEB, do Grupo Ismael e do "Serviço de Assistência aos Necessitados” -, um dos seus aspectos mais específicos, que mais contornos recebeu e que acabou se tornando a marca distintiva do espiritismo foi, portanto, o aspecto taumatúrgico. Com efeito, a propagação do espiritismo no Brasil deveu-se muito à atuação dos médiuns, sobretudo dos médiuns “curadores”. A cura mediúnica, além de um exercício importante de caridade, valia também enquanto comprovação da existência e da interferência dos espíritos, sendo a forma mais direta, sem muitas mediações, de expansão das crenças espíritas. Por isso é que talvez o aspecto taumatúrgico que tomou a prática da caridade naquele momento, essa virtude tão exaltada no mundo espírita brasileiro e essencial para a salvação, tenha sido fator fundamental de diferenciação e de conformação do espiritismo não só perante outras manifestações religiosas do campo, mas também perante o espiritismo francês. 


\section{"A fé move montanhas"}

Bezerra de Menezes, médico alopata por formação, não chegou a estudar homeopatia. Não obstante, ele mesmo acabou se tornando um dos médiuns "receitistas" da sua Federação, guiado em suas prescrições por seu “espírito-protetor”. A arte de curar era, para ele, um ato de caridade contínuo que deveria ser posto em prática fosse através da alopatia, fosse através da homeopatia, fosse através da terapêutica espírita em suas mais variadas formas. Com efeito, ele foi um dos maiores responsáveis por propagar e expandir o dispensário homeopático, ou melhor, segundo suas palavras: “a medicina dos espíritos”; e o fez de um modo bem particular: dando-lhe um sentido religioso.

Bezerra promoveu uma sutil diferença entre o seu espiritismo e o espiritismo de Kardec ao colocar de lado as reservas deste último em relação à conveniência da cura espiritual de qualquer sorte. Para Allan Kardec, o que contava antes de tudo era o mérito do indivíduo decorrente da aplicação da Lei de Ação e Reação. Isso significa dizer que as curas espíritas nem sempre viriam a se tornar realidade, já que dependeriam diretamente do merecimento do necessitado, isto é, de um cálculo feito através dessa "lei espírita", que obrigaria o indivíduo a responder por suas próprias ações.

Invocando o dogma da infinita misericórdia de Deus, Bezerra de Menezes afirmava, por sua vez, que todas as curas poderiam ser sim possíveis desde que a crença absoluta nessa misericórdia fosse suficientemente forte. Era assim que Bezerra convertia um princípio original do espiritismo, que dava proeminência à responsabilidade individual, para outro mais católico, digamos, de absolvição das dores e penas por causa da fé em Deus.

A fé tornava-se então uma qualidade de conviç̧ão e enquanto tal passava a ser apresentada como mais um meio de salvação espírita. O apego pessoal a um Deus e uma confiança extraordinária na sua Providência é algo mais do que um "saber racional” e, por conta disso, chama-se fé. Essa virtude ou qualidade supõe que seja tomado por verdadeiro o desenvolvimento de 
determinados dogmas, cuja aceitação é considerada um sinal de pertencimento ao grupo. Com a existência de um grau progressivo de "doutrina religiosa", característica distintiva que passou a ter, esse espiritismo cada vez mais sistematizado e moralizado desenvolvia a crença no sentido de tomar por verdadeiros os dogmas intelectualmente compreendidos que, por sua vez, foram produtos de reflexão intelectual.

Muito embora originalmente a questão da fé já tivesse sido apresentada em Allan Kardec, sendo por ele concebida enquanto "fé raciocinada”, isto é, algo que devesse ser atingido racionalmente, entendido e compreendido - concepção, aliás, compartilhada inicialmente por Bezerra -, a fé espírita acabou sofrendo certas modificações promovidas por este último. Fazendo-o de uma forma quase imperceptível, era como se a fé se tornasse agora uma espécie de sucedâneo último de todas as formas de salvação no espiritismo, salvação que, a propósito, já se dava desde a vida presente (com o alívio dos males de toda ordem), sem necessitar esperar por ela após a morte ${ }^{129}$.

${ }^{129}$ No livro de Ramiro Gama (2001), abundam histórias sobre passagens da vida de Bezerra de Menezes que exaltam as suas ações caridosas, numa linguagem extremamente emotiva e sentimental, como convém a uma hagiografia. Entre elas, há muitas que falam não só da sua fé como também das suas recomendações aos que a ele se achegavam, de que era necessário ter fé em Deus e em Jesus, mas também em Maria, personagem bastante venerada por Bezerra. Citamos a título de exemplo uma passagem que se encontra à página 75 do referido livro:

"Encerrada a sessão daquela terça-feira, no centro espírita da FEB., Bezerra de Menezes saiu, sendo na rua abordado por um homem, cabelos em desalinho, cansado e aflito, a dizer-Ihe:

- Dr. Bezerra, estou sem emprego, com a mulher e dois filhos doentes e famintos. $E$ eu mesmo, como vê, estou sem alimento e febril...

Bezerra, apiedado, verificou se tinha algum dinheiro para dar. Mas não encontrou nada, além da passagem do bonde. Levantou então os olhos em prece silenciosa, pedindo inspiração a Maria. Depois, virando-se para o irmão, disse comovido:

- Meu filho, você tem fé em Nossa Senhora, a Mãe do Divino Mestre Jesus, a Nossa Mãe Querida?

- Tenho, sim, e muita, Dr. Bezerra! 
Tão poderosa veio a se tornar, que todos os tratamentos terapêuticos espíritas, por exemplo, quando ministrados ou recebidos com fé, teriam bons resultados por conta disso. E se com fé se adotasse o espiritismo e todos os seus pressupostos e conseqüências; se com fé e convicção uma pessoa se tornasse verdadeiramente espírita; com fé tudo melhoraria; com fé tudo poderia se transformar; com fé se salvaria.

- Pois então, meu filho, em nome da Virgem Santa, receba este abraço.

E abraçou o desesperado irmão, envolvente e demoradamente. E, despedindo-se dele, disse o Dr. Bezerra:

- Vá, meu filho, na Paz de Jesus e sob a proteção de Maria, Mãe de Deus. E, ao chegar em casa, faça o mesmo com seus familiares, abraçando-os e afagando-os com ternura. E confie n'Ela, sim, no Amor de Maria, que seu caso será resolvido. 


\section{Considerações finais}

Mostrou-se pormenorizadamente nos dois primeiros capítulos desta dissertação que, não sendo algo definido desde seu início, nem na França nem tampouco no Brasil, a reivindicação do caráter religioso do espiritismo durante a primeira República representava a escolha de uma via de legitimação social baseada no amparo legal. Ou até mais do que isso. Apresentá-lo como uma religião era visto como uma solução portadora de uma segurança legal que era sentida como premente para a existência do movimento espírita em chão brasileiro. Isso foi demonstrado aqui pelo exame dos trabalhos de Bezerra de Menezes e seus seguidores. Esse processo de "religiosificação" do espiritismo (com perdão do tosco mas necessário neologismo) não consistia simplesmente na explicitação de uma forma possível, ensejada por seu sistema conceitual, de definir aquele conjunto de práticas e concepções: foi o meio concreto pelo qual uma possível interpretação pôde ser aceita como ortodoxa e hegemônica por aqueles a quem cabia aceitá-la.

Do ponto de vista teórico aqui adotado, a formação do espiritismo se mostrou emoldurada pela lógica de um campo (Cf. BOURDIEU), o campo religioso brasileiro, também ele em processo de formação e em vias de autonomização como âmbito de disputas entre forças religiosas múltiplas (antigas e novas). E foi essa a maneira vitoriosa de viabilizá-lo no Brasil como prática coletiva desenvolvida em uma forma, também esta em desenvolvimento, de agrupamento comunitário religioso. Houve, é verdade, outras tentativas de introduzi-lo sustentavelmente, respeitando outros moldes; mas aqueles que assim o tentaram e para isso trabalharam não reuniram as mesmas condições - entre as quais uma suficiente carteira de capitais — para o conseguir. Venceu a peleja o espiritismo religioso, representando-se nomeadamente como cristão: "espiritismo cristão". Desde então todo espírita no Brasil se entende como praticante de mais uma religião cristã. 
Apesar da vitória dessa corrente interna, ou até por causa dela, as disputas não acabaram. Mas no final das contas o resultado para o conjunto do meio espírita brasileiro foi positivo, pelo menos o resultado tal como repercutiu e se consolidou de forma duradoura entre a grande maioria de seguidores e ideólogos. Ao longo de um século, segundo pesquisas realizadas pelo Centro de Pesquisas Psico-sociais do Centro de Estudos Espíritas Leon Denis, foi observado que certos termos utilizados no final do século XIX estão praticamente ausentes da linguagem espírita atual, tais como espiritismo científico e espiritismo puro. Isso é mais um indicador da vitória que tiveram Bezerra de Menezes e seguidores em conferir à interpretação do que entendiam por espiritismo o status de vigência hegemônica (legítima, vale dizer) que hoje tem.

Foi assim que o espiritismo no Brasil, num processo fundamentalmente de iniciativa dos agentes intelectuais daqui, começou a ser constituído a partir do final do século XIX de forma bem diferente do movimento espírita francês, o qual, na mesmíssima época, não se preocupava em apresentar o espiritismo enquanto uma religião prima facie. Quando a Revue Spirite notificou a publicação no Brasil do periódico O Echo d'Além Túmulo, os espíritas descendentes de Kardec nem de longe suspeitavam que, por trás e apesar do tom abertamente anticlerical do mencionado periódico, Telles de Menezes pensasse como alguém que hoje se poderia chamar de “espiritólico”, já que conciliava tranqüilamente os princípios espíritas com reconhecidas crenças católicas, como o dogma da ressurreição, por exemplo. Bezerra de Menezes, além do mais, era o que se pode chamar de “mariólatra”, e nunca abandonou sua simpatia pelo catolicismo, do mesmo modo que seus colegas, também eles roustainguistas, todos do círculo da Federação Espírita Brasileira. Essa mistura é um traço presente até hoje entre os nossos espíritas e entre os nossos católicos, configurando-se com isso um jeito brasileiro de ser espírita tanto quanto de ser católico no Brasil. Aqui neste lado do mundo, enquanto se tem quase a metade de católicos que acreditam na reencarnação, há nada menos que três quartos de espíritas que crêem que Jesus nasceu de Maria 
Virgem e que ressuscitou dos mortos, crenças fundamentalmente católicas (BEGUOCI, 2007).

Seguindo esse caminho, o segundo passo da dissertação foi no sentido de mostrar como o espiritismo à brasileira - para além do qualificativo religioso - foi-se fazendo também filantrópico e taumatúrgico. Não somente a partir das formulações da assim chamada “trindade do espiritismo” - Bezerra de Menezes, Bittencourt Sampaio e Antônio Luiz Sayão - como também a partir da aplicação de esforços da parte de outros espíritas. Entretanto, foi sobretudo daqueles o trabalho religioso de emoldurar a doutrina espírita de forma a acentuar as divisas "Deus, Cristo e Caridade” e "Fora da caridade não há salvação”. Também é resultado de lutas intestinas e resposta a pressões externas o valor sobremaneira acentuado que se atribui à prática da caridade no espiritismo brasileiro, um preceito moral basilarmente bíblico-evangélico, relançado com ênfase a partir de investimentos práticos e teóricos dos intelectuais espíritas postos em exame na historiografia desta pesquisa.

Desse modo, tornou-se mais fácil o caminho para se compreender como se deram - e quais foram - as “afinidades eletivas” (Cf. WEBER, 2004, p. 83), como diria Max Weber, entre certos grupos sociais e determinados sistemas de pensamento com o espiritismo. Pois o que se pretendeu fazer na última etapa deste trabalho foi mostrar que tais afinidades eletivas se reforçaram e garantiram sua reprodução no processo de mudança qualitativa de um ethos espírita, pensado aqui enquanto esquemas implícitos de ação e de apreciação de facto, em uma ética espírita, um conjunto sistematizado e racionalizado de normas morais explícitas, cuja violação é tratada de jure como uma falta com o dever. Isso, graças ao trabalho “religiosificador” dos intelectuais do espiritismo, cujos efeitos de consagração, ou seja, de legitimação, conseguiram submeter um sistema de disposições frente ao mundo natural e ao mundo social (disposições inculcadas pelas condições de existência) a uma mudança de natureza do vínculo normativo, convertendo 
ethos em ética. Noutras palavras, um trabalho de sistematização e de eticização.

É por essa razão que a nova religião espírita, como as demais religiões e contra elas, passou a poder assumir uma função ideológica prática, implicitamente política, de legitimação das coordenadas sociais vivenciadas pelos indivíduos que aderem a ela ou aos quais ela adere. Função que só seria efetivamente cumprida na medida em que fosse capaz de cumprir uma outra função: a de tornar coerente e conferir sentido ético a uma visão de mundo conectada a um estilo de vida, fazendo acrescer, por conseguinte, a força material e simbólica passível de mobilização por seu grupo de seguidores. Por definição, são os interesses especificamente religiosos imbricados às diferentes posições ocupadas pelos agentes na estrutura social que carregam a função genérica da religião de “absolutizar o relativo e legitimar o arbitrário”, na concepção teórica de Bourdieu (1974, p.27-78; 79-98). Segundo ele, é dessa forma que se torna possível analisar o interesse religioso em seu sentido mais pertinente e amplo para a sociologia. Isso quer dizer que o interesse concreto que um grupo de indivíduos encontra num tipo determinado de prática ou crença religiosa associada a determinados bem de salvação coincide com o próprio interesse (ideal, mas também material) que encontra na produção desse bem, em sua reprodução e difusão para consumo ampliado. Noutras palavras: o interesse religioso é interesse pelo trabalho religioso.

A perspectiva aqui adotada, por isso, seguiu em sentido divergente da direção seguida pelos outros trabalhos que analisaram, de uma forma ou de outra, o surgimento e algumas das características do espiritismo no Brasil ${ }^{130}$. Porque o que se vê nessa literatura são menções que se limitam ao seu caráter marcadamente filantrópico, mas nunca uma análise do modo pelo qual ele se

130 AUBRÉE; LAPLANTINE (1990); CAMARGO (1961, 1973); CAMURÇA (1998, 2001) CAVALCANTI (1983); DAMAZIO (1994); DOYLE (1981); GIUMBELLI (1997a, 1997b, 1998, 2002a); HESS (1987a, 1987b); LEWGOY (2000, 2004); MACHADO (1983); MAGGIE (1992, 1986); SANTOS (1997); SCHRITZMEYER (2004); SILVA, Luiz (2005); STOLL (1999); WARREN $(1984,1986)$. 
desenvolveu e pelas mãos de quem ele se tornou uma realidade social no Brasil. Segundo a maior parte dos estudos, a caridade - um ato desinteressado e benéfico realizado em favor de outrem e sem fins lucrativos - teria sido apenas um traço imposto por forças externas ao espiritismo. Essa é uma possível decorrência a que se pode chegar a partir da leitura dos trabalhos já mencionados anteriormente. Neles é como se o espiritismo passasse a ser religioso e a adotar práticas de prestação de auxílio gratuito somente para escapar ileso ao Código Penal, uma vez que este previa a redução da pena ou a anulação dos processos que envolviam práticas mágico-religiosas-curativas se elas tivessem sido praticadas sem fins lucrativos, desinteresse material que demonstraria seu caráter religioso.

No processo aqui rastreado, o da especificação da individualidade do espiritismo no Brasil sendo construída no bojo do processo mais amplo e inclusivo de pluralização confessional por que passava o campo religioso brasileiro, foi crucial, para que esta pesquisa chegasse aos resultados a que foi chegando pouco a pouco, levar na devida conta as transferências de crenças religiosas que se deram entre o espiritismo religioso e o catolicismo. Porque de fato - como tentamos demonstrar - observá-los agindo ora um "contra” o outro, ora um "com" o outro, ajudou a compreendê-los do ponto de vista de suas "afinidades eletivas" religiosas. Assim se pôde compreender melhor por que o campo religioso brasileiro nunca deixou de ter e reproduzir como matriz, apesar da progressiva quebra do monopólio católico no transcorrer do século $\mathrm{XX}$, o modelo de religiosidade pautado num cristianismo católico bastante brasileiro. 


\section{Bibliografia, fontes e biografias}

\section{Bibliografia}

- ALVES, Márcio Moreira. A igreja e a política no Brasil. São Paulo: Editora Brasiliense, 1979.

- ALVES, Rubens. Protestantismo e repressão. São Paulo: Ed. Ática, 1982.

- AUBRÉE, Marion; LAPLANTINE, François. La Table, le livre et les esprits. Paris: S.l. Jean Claude Lattes, 1990.

- AUBRÉE, Marion. De l'histoire au mythe : La dynamique des romans spirites au Brésil. In : MARTIN, Jean-Baptiste ; LAPLANTINE, François. Le défi magiques. Ésoterisme, occultisme, spiritisme. Lyon: Presses Universitaires de Lyon, 1994.

- _ _ La nouvelle dynamique du spiritisme kardéciste. Ethnologie Française, vol. XXX, 4, p. 591-599, 2000.

- AZZI, Riolando. O início da restauração católica no Brasil. Síntese, vol. IV, n. ${ }^{\circ}$ 10, p. 61-89, 1977.

- _ _ O episcopado brasileiro frente à revolução de 1930. Síntese, vol. V, n. o 12, p. 47-78, 1978.

- _ _ O fortalecimento da restauração católica no Brasil (1930-1940). Síntese, vol. VI, n. ${ }^{0}$ 17, p. 69-85, 1979.

- _ A igreja católica no Brasil durante o Estado Novo. Síntese, vol. VII, n. ${ }^{\circ}$ 19, p. 49-71, 1980.

- _ A Igreja no regime republicano. Religião e Sociedade. Rio de Janeiro, n. ${ }^{\circ} 13(3)$, p. 76-91, 1986.

- BARROS, Maciel. A ilustração brasileira e a idéia de universidade. História e Filosofia da Educação. São Paulo, n. ${ }^{0}$ 241, 1959.

- BASTIDE, Roger. Religiões africanas no Brasil. São Paulo: Pioneira, 1971.

- _ _ _ Estudos afro-brasileiros. São Paulo: Universidade, 1953.

- BERGER, Peter Ludwig. Dossel sagrado elementos para uma teoria sociológica da religião. São Paulo: Paulus, 1985.

- _ A A dessecularização do mundo. Religião e Sociedade, Rio de Janeiro, n. ${ }^{\circ} 21(1)$, p. 9-23, 2001.

- BOURDIEU, Pierre. A economia das trocas lingüísticas. São Paulo: EDUSP, 1996.

- _ _ _ _ As regras da arte. São Paulo: Companhia das Letras, 1996.

- _ _ _ _ O poder simbólico. Rio de Janeiro: Bertrand Brasil, 1998. 

. A economia das trocas simbólicas. São Paulo: Perspectiva, 2001. Meditações pascalianas. Rio de Janeiro: Bertrand Brasil, 2001.

$\bullet$ . A produção da crença. São Paulo: Zouk, 2004.

$\bullet$ . Esboço de auto-análise. São Paulo: Companhia das Letras, 2005.

- BROWN, Diana (org.). Umbanda e política. Rio de Janeiro: Ed. Marco Zero, 1985.

- _ _ O papel histórico da classe média na umbanda. Religião e Sociedade, Rio de Janeiro, n. ${ }^{\circ}$ 1(1), p. 31-50, 1997.

- BRUNEAU, Thomas. O catolicismo no Brasil em época de transição. São Paulo: Edições Loyola, 1974.

- BURKE, Peter. Sociologia e história. Porto: Edições Afrontamento, 1980.

- CAMARgO, Cândido Procópio Ferreira de. Kardecismo e umbanda. São Paulo: Pioneira Ed., 1961.

- _ _ C Católicos, protestantes, espíritas. Petrópolis: Editora Vozes, 1973.

- CAMURÇA, Marcelo A. Entre a graça e a evolução: Reflexões sobre o conceito de reencarnação no catolicismo e espiritismo. Revista Eclesiástica Brasileira, vol. 58, fasc. 230, p. 385-402, 1998.

- _ _ Fora da caridade não há religião! Breve história da competição religiosa entre catolicismo e espiritismo kardecista e de suas obras sociais na cidade de Juiz de Fora: 1900-1960. Lócus - Revista de História, vol. 7, n. 1, p. 131-154, 2001.

- — - O C conceito de reencarnação no espiritismo moderno: Entre o círculo de Samsara e o evolucionismo positivista. Numem - Revista de Estudos e Pesquisa de Religião, vol. 3, n. 1, p. 95-105, 2000.

. Le Livre des Esprits na manchester mineira: A modernidade do espiritismo face ao conservadorismo católico nas primeiras décadas do século em Juiz de Fora. Rhema - Revista de Filosofia e Teologia do Instituto Teológico de Santo Antonio, vol. 4, n. 16, p. 199-223, 1998.

- CASTELlan, Yvonne. Le spiritisme. Paris: Presses Universitaires de France, 1995.

- CAVALCANTI, Maria Laura. O mundo invisível. Rio de Janeiro: Ed. Zahar, 1983.

- CONCONE, Maria Helena Vilas Boas. Umbanda: Uma religião brasileira. São Paulo: FFLCH/USP-CER, 1987.

- _ _ Ideologia umbandista e integralismo. Ciências Sociais Hoje, p. 379395, 1981,

- DAMAZIO, Sylvia F. Da elite ao povo: Advento e expansão do espiritismo no Brasil. Rio de Janeiro: Bertrand Brasil, 1994.

- DOYLE, Athur Conan. Le histoire du spiritisme. Traduzido do inglês por Claude Gilbert. Monaco: Éditions du Rocher, 1981. 
- ELIAS, Norbert. La sociedad cortesana. México: Fondo de Cultura Económica, 1996.

- _ _ _ A sociedade dos indivíduos. Rio de Janeiro: Jorge Zahar, 1994.

- _ _ _ _ Mozart, sociologia de um gênio. Rio de Janeiro: Jorge Zahar, 1997.

- FEITOSA, Maria Florice Raposo Pereira. A razão de tantas vidas: Racionalidade mística na religiosidade espírita. São Paulo: Annablume, 2000.

- FERNANDES, Aníbal Gonçalves. O sincretismo religioso no Brasil. Curitiba: Guaiara, 1941.

- FERNANDES, Magali, Oliveira. Luiz Olympio Telles de Menezes: Os primeiros momentos da edição kardecista no Brasil. Dissertação (Mestrado em Comunicação) - Escola de Ciências e Arte, Universidade de São Paulo, São Paulo, 1993.

- FERnANDES, Rubem. Censo institucional evangélico - 1992. Rio de Janeiro: ISER, 1992.

- GIUMBELLI, Emerson. O cuidado dos mortos: Uma história da condenação e legitimação do Espiritismo. Rio de Janeiro: Arquivo Nacional, 1997a.

- _ _ Heresia, doença, crime ou religião: O espiritismo no discurso de médicos e cientistas sociais. Revista de Antropologia. São Paulo, USP, vol. 40, n. ${ }^{\circ}$ 2, p. 33-82, 1997b.

- _ _ C Caridade, assistência social, política e cidadania: Práticas e reflexões no espiritismo. In: LADIN, Leilah (org.). Ações em sociedade: Militância, caridade, assistência. Rio de Janeiro: NAU / ISER, 1998.

- _ _ Introdução ; Brasil, historicamente. In: O fim da religião. São Paulo: Attar Editorial, 2002a.

- _ _ Zélio de Moraes e as origens da umbanda no Rio de Janeiro. In: SILVA, Vagner Gonçalves (org.). Caminhos da alma: Memórias afrobrasileiras. São Paulo: Summus, 2002b.

- HERVIEU-LÉGER, Danièle; WILLAIME, Jean-Paul. Max Weber (18641920). Gènese religieuse de la modernité occidentale, rationalisation et charisme. In : Sociologies et religion. Approches classiques. Paris : Presses Universitaires de France, 2001.

- HESS, David. The many rooms of spiritism in Brazil. Luso-Brazilian Review, XXIV, n.2, p. 15-34, 1987a.

- — $\quad$ O espiritismo e as ciências. Religião e Sociedade. Rio de Janeiro, n. ${ }^{\circ} 4(3)$, p. 40-54, $1987 \mathrm{~b}$.

- LEPENIES, Wolf. Introdução ; França. In: As três culturas. São Paulo: Edusp, 1996.

- LEWGOY, B. Os espíritas e as letras. Tese (Doutorado em Antropologia) Faculdade de Filosofia, Letras e Ciências Humanas, Universidade de São Paulo, São Paulo, 2000. 
- _ _ C Chico Xavier. O Grande Mediador. Bauru: EDUSC, 2004.

- LIMA, Delcyr de Souza. Analisando crenças espíritas e umbandistas. Rio de Janeiro: JUERP, 1986.

- LÖWY, Michael ; DIANTEILL, Erwan (orgs.). Pierre Bourdieu (1930-2002), explorateur du champ religieux. In : Sociologies et religion. Approches dissidents. Paris: Presses Universitaires de France, 2005.

- MACHADO, Ubiratan. Os intelectuais e o espiritismo. Rio de Janeiro: Edições Antares, 1983.

- MAGGIE, Yvonne. Medo do feitiço: Relações entre magia e poder no Brasil. Rio de Janeiro: Arquivo Nacional, 1992.

- ـ _ _ O O medo do feitiço - verdades e mentiras sobre a repressão às religiões mediúnicas. Religião e Sociedade, Rio de Janeiro, n. ${ }^{\circ}$ 13(1), p. 72-86, 1986.

- MARIZ, Cecília Loreto Mariz. Secularização e dessecularização: Comentários a um texto de Peter Berger. Religião e Sociedade, Rio de Janeiro, n. ${ }^{\circ}$ 21(1), p. 25-39, 2001.

- MARX, Karl. O Capital. São Paulo: Nova Cultura, 1988, vol. I

- MICELI, Sérgio. A elite eclesiástica brasileira. Rio de Janeiro: Ed. Bertrand Brasil, 1988.

- _ Fontes para o estudo da elite eclesiástica brasileira (1890-1930). Bib, São Paulo, n. ${ }^{\circ}$ 18, p. 301-334, 1984.

- MONTERO, Paula. Da doença à desordem: Magia na umbanda. Rio de Janeiro: Edições Graal, 1985.

- MONTERO, Paula. A cura mágica na umbanda. Comunicações ISER, Rio de Janeiro, n. ${ }^{\circ}$ 20, julho, p. 39-47, 1986 .

- _ _ _ Magia e pensamento mágico. São Paulo: Ática, 1986b.

- _ _ _ Religiões e dilemas da sociedade brasileira. In: MICELI, Sérgio (org.). O que ler nas ciências sociais brasileira (1970-1995). São Paulo: Sumaré/ANPOCS/CAPES, 1999.

- _ _ Max Weber e os dilemas da secularização: O lugar da religião no mundo contemporâneo. Novos Estudos, São Paulo, n. ${ }^{\circ}$ 65, março, p. 34-44, 2003.

- — Religião, pluralismo e esfera pública no Brasil. Novos Estudos. São Paulo, n. ${ }^{\circ}$ 74, março, p. 47-65, 2006.

- NEGRÃO, Lísias Nogueira. Entre a cruz e a encruzilhada. São Paulo: EDUSP, 1996a.

- _ _ Magia e religião na umbanda. Revista USP, set./out./nov., p. 76-89, 1996b.

- _ _ A umbanda como expressão da religiosidade popular. Religião e Sociedade, Rio de Janeiro, $\mathrm{n}^{\circ}$. 4, p. 171-180, 1979. 1986.

. Mito e magia. Comunicações do ISER, ano V, nº. 20, julho, p. 56-57, 

. A construção sincrética de uma identidade. Ciências Sociais Hoje. São Paulo: Vértice, p. 208-230, 1991a.

- ㄴ. Cultos afro-brasileiros: O que são e como são vistos. Travessia, ano IV, n. 10, maio/ago., p. 12-18, 1991b.

- _ _ Umbanda: entre a cruz e a encruzilhada. Tempo Social, São Paulo, nov., p. 113-122, 1994.

- _ . Nem 'jardim encantado', nem 'clube dos intelectuais desencantados'. Revista Brasileira de Ciências Sociais, vol. 20, n. . 59, outubro, p. 124-161, 2005.

- ORTIZ, Renato. A morte branca do feiticeiro negro: Umbanda e sociedade brasileira. São Paulo: Brasiliense, 1988.

- _ _ Ética, poder e política: Umbanda, um mito-ideologia. Religião e Sociedade, dez., p. 36-54, 1984.

- _ $\quad$ O mercado religioso. Comunicações do ISER. Rio de Janeiro, n. ${ }^{0}$, setembro, p. 25-32, 1983.

- _ _ _ Do sincretismo à síntese ; Gramsci/Weber: Contribuição para uma teoria da religião. In: A consciência fragmentada. Rio de Janeiro: Paz e Terra, 1980.

- PIERUCCI, Antonio Flávio. Interesses religiosos dos sociólogos da religião. In: ORO, Ari Pedro; STEIL, Carlos Alberto (orgs.). Globalização e religião. Petrópolis: Vozes, 1997a.

- _ _ Reencantamento e dessecularização. Novos Estudos, São Paulo, n. ${ }^{\circ} 49$, novembro, p. 99-117, 1997b.

- _ _ Secularização segundo Max Weber. In: SOUZA, Jessé (org.). A atualidade de Max Weber. Brasília: Editora da Universidade de Brasília, 2000.

- _ _ Sociologia da Religião: área impuramente acadêmica. In: MICELI, Sérgio (org.). O que ler na Ciência Social Brasileira (1970-1995). São Paulo: Sumaré/ANPOCS/CAPES, 1999.

- _ _ Religião como solvente - uma aula. Novos Estudos, São Paulo, n. ${ }^{\circ}$ 75, julho, p. 111-127, 2006.

- _ _ Liberdade de cultos na sociedade de serviços. Novos Estudos, São Paulo, n. ${ }^{\circ} 44$, março, p. 3-11, 1996.

- _ . O desencantamento do mundo: Todos os passos de um conceito. São Paulo: Editora 34, 2003.

- PINHEIRO, Fernando. A invenção da ordem: intelectuais católicos no Brasil. Tempo Social. São Paulo, vol. 19, n. ${ }^{\circ}$ 1, junho, p. 33-49, 2007.

- PRANDI, Reginaldo. A mitologia dos orixás. São Paulo: Companhia das Letras, 2001.

- — De africano a afro-brasileiro: etnia, identidade e religião. Revista USP, São Paulo, n. ${ }^{\circ}$ 46, p. 52-65, 2000. 
- _ _ _ Os candomblés de São Paulo. São Paulo: Hucitec/EDUSP, 1991.

- _ _ _ Segredos Guardados. São Paulo: Companhia das Letras, 2005.

- RIBEIRO, Mario Bueno. As relações entre protestantismo e catolicismo no Brasil. Dissertação (Mestrado), IMESP, São Paulo, 1996.

- RIO, João do. As religiões no Rio. Rio de Janeiro: José Olympio, 2006.

- RODRIGUES, Solange dos Santos. Trabalhos apresentados no GT Religião e Sociedade da ANPOCS (1980-1997). Religião e Sociedade. Rio de Janeiro, 18(2), p. 157-179, 1997.

- SALLES, David. Primeiras manifestações da ficção na Bahia. São Paulo: Cultrix, 1979.

- SANTOS, José Luis dos. Espiritismo: uma religião brasileira. São Paulo: Moderna, 1997.

- SCAMPANI, J. Liberdade religiosa nas constituições brasileiras. Petrópolis: Vozes, 1978.

- SCHRITZMEYER, Ana Lúcia Pastore. Sortilégio de saberes: Curandeiros e juizes nos tribunais brasileiros (1900-1990). São Paulo: IBCCRIM, 2004.

- SERPA, Elio Cantalicio. Igreja, elites dirigentes e catolicismo. Tese (Doutorado em História) - Faculdade de Filosofia, Letras e Ciências Humanas, Universidade de São Paulo, São Paulo, 1993.

- $\quad$ SILVA, Luiz da. Espiritismo. Londrina: Eduel, 2005.

- SILVA, Vagner Gonçalves da. Candomblé e umbanda: Caminhos da devoção. São Paulo: Selo Negro, 2005.

- SACHS, Viola et al. Religião e identidade nacional. Rio de Janeiro: Graal, 1988.

- STOLL, Sandra Jaqueline. Entre dois mundos: O espiritismo na França e no Brasil. Tese (Doutorado em Antropologia) - Faculdade de Filosofia, Letras e Ciências Humanas, Universidade de São Paulo, São Paulo, 1999.

- TORRES, João Camilo de Oliveira. História das idéias religiosas no Brasil. São Paulo: Ed. Grijalbo, 1968.

- TRINDADE, Liana Maria Salvia. Construções míticas e históricas: Estudos sobre as representações simbólicas e relações raciais em São Paulo do século XVIII à atualidade. Tese (Livre Docência em Antropologia) Faculdade de Filosofia, letras e Ciências Humanas, Universidade de São Paulo, São Paulo, 1991.

- VALENTE, Waldemar. Sincretismo religioso afro-brasileiro. São Paulo: Cia Ed. Nacional, 1955.

- WARREN, Donald. A terapia espírita no Rio de Janeiro por volta de 1900. Religião e Sociedade, Rio de Janeiro, n. ${ }^{0} 11(3)$, p. 56-83, 1984.

- _ _ A medicina espiritualizada. Religião e Sociedade, Rio de Janeiro, n. ${ }^{\circ}$ 13(1), p. 88-107, 1986. 
- WEBER, Max. Sociologia da religião ; Estamentos e classes. In: Economia e sociedade: Fundamentos da Sociologia Compreensiva. Brasília: Ed. Universidade de Brasília, 2000a, vol. I.

- — A dominação não legítima (Tipologia das cidades). In:

Economia e sociedade: Fundamentos da Sociologia Compreensiva. Brasília: Ed. Universidade de Brasília, 2000b, vol. II.

- _ _ Psicologia social das religiões mundiais ; Rejeições religiosas do mundo e suas direções ; Classe, estamento, partido ; A ciência como vocação. In: . Ensaios de sociologia. Rio de Janeiro: LTC, 1982.

- _ _ A ética protestante e o “espírito” do capitalismo. São Paulo: Companhia das Letras, 2004.

- _. Introducción. In: Madri: Taurus, 1987. . Ensayos sobre sociología de la religión.

- _ Confucionismo e puritanismo. In: COHN, Gabriel (org.). Max Weber. São Paulo: Ática, 2002.

\section{Fontes}

\section{Biografias e publicações espíritas}

- ABREU, Canuto. Bezerra de Menezes. São Paulo: Edições FEESP, 1996a.

- — O O Livro dos Espíritos e sua tradução histórica e lendária. São Paulo: LFU, 1996b.

- AMigo Y PellíCER, José. Roma e o Evangelho. Rio de Janeiro: Federação Espírita Brasileira, 1982.

- AMORIM, Deolindo. Africanismo e espiritismo. Rio de Janeiro: Mundo Espírita, 1949.

- $\quad$. $\quad$ O espiritismo e as doutrinas espiritualistas. Rio de Janeiro: Centro Espírita Leon Denis, 1988.

- ANJOS, Luciano dos. Os adeptos de Roustaing. Volta Redonda: AEEV, 1993.

- AQUARONE, Francisco. Bezerra de Menezes, o médico dos pobres. São Paulo: Editora Aliança, 1980.

- BARBOSA, Pedro Franco. Espiritismo básico. Rio de Janeiro: Federação Espírita Brasileira, 1987.

- BEZERRA, Menezes. Uma carta de Bezerra de Menezes. Rio de Janeiro: Federação Espírita Brasileira, 1963.

- _ _ Estudos filosóficos. São Paulo: EDICEL, 1977a, vol. II. 
- _ _ Estudos filosóficos. São Paulo: EDICEL, 1977b, vol. III.

- _ _ Loucura sob novo prisma. Rio de Janeiro: Federação Espírita Brasileira, 1996.

- BLACKWELL, Anna. Translator's preface. In: The Spirits' Book. São Paulo: LAKE, [s/d].

- CIRNE, Leopoldo. Antichristo. Senhor dos mundos. Rio de Janeiro: Federação Espírita Brasileira, 1935.

- DELANE, Gabriel. O espiritismo perante a ciência. Rio de Janeiro: Federação Espírita Brasileira, 2004.

- DENIS, Leon. Socialismo e espiritismo. Matão: Casa Editora O Clarim, 1987.

- FEDERAÇÃO ESPÍRITA BRASILEIRA. Esboço histórico da FEB. Rio de Janeiro: Federação Espírita Brasileira, 1924. Brasileira, 1907.

As curas espíritas perante a lei. Rio de Janeiro: Federação Espírita A presença da Igreja no Brasil. São Paulo: Giro, 1977.

- GAMA, Ramiro. Lindos casos de Bezerra de Menezes. São Paulo: LAKE, 2001.

- IMBASSAHY, Carlos. O espiritismo à luz dos fatos. Rio de Janeiro: Federação Espírita Brasileira, 1935.

- KARDEC, Allan. O livro dos espíritos. São Paulo: LAKE, 2001a.

- _ _ _ A gênese. São Paulo: IDE, 2001b.

- — _ _ O livro dos médiuns. São Paulo: LAKE, 1998.

- _ _ _ O Evangelho segundo o espiritismo. São Paulo: LAKE, 2000.

- _ _ _ O que e espiritismo. Rio de Janeiro: Federação Espírita Brasileira, 2004.

- _ _ _ O O céu e o inferno. São Paulo: LAKE, 2002.

- _ _ _ _ Obras póstumas. São Paulo: Instituo de Difusão Espírita, 1993.

- _ _ _ V Viagem espírita em 1862. Matão: Casa Editora O Clarim, 2000.

- MARTINS, Jorge Damas. Ponte evangélica. De Bordéus a Pedro Leopoldo. Rio de Janeiro: Grupo Espírita Regeneração, 1984.

- _ _ Jean-Baptiste Roustaing - Apóstolo do espiritismo. Rio de Janeiro: Crbbm, 2005.

- MARTINS, Jorge Damas; BARROS, Stenio Monteiro. Allan Kardec. Análise de documentos biográficos. Niterói: Lachâtre, 1999.

- MESquitA, José Marques. A dialética espiritualista. Rio de Janeiro: Editora Mandarino, 1985.

- RAMOS, Clóvis. A imprensa espírita no Brasil: 1869-1978. Juiz de Fora: Instituto Maria, 1979. 
- RIBEIRO, Guillon. Trabalhos do Grupo "Ismael” da Federação Espírita Brasileira. Rio de Janeiro: Federação Espírita Brasileira, 1941a, vol. I.

- _ _ Trabalhos do Grupo “Ismael” da Federação Espírita Brasileira. Rio de Janeiro: Federação Espírita Brasileira, 1941b, vol. II.

- ROUSTAING, Jean-Baptiste. Espiritismo cristão ou revelação da revelação. Os quatro evangelhos. Rio de Janeiro: Federação Espírita Brasileira, 1983, vol. I.

- — Espiritismo cristão ou revelação da revelação. Os quatro evangelhos. Rio de Janeiro: Federação Espírita Brasileira, 1983, vol. II.

- —_ Espiritismo cristão ou revelação da revelação. Os quatro evangelhos. Rio de Janeiro: Federação Espírita Brasileira, 1983, vol. III.

- _ _ Espiritismo cristão ou revelação da revelação. Os quatro evangelhos. Rio de Janeiro: Federação Espírita Brasileira, 1983, vol. IV.

- SAMPAIO, Bittencourt. A divina epopéia de João Evangelista. Rio de Janeiro: Federação Espírita Brasileira, 1988.

- _ _ _ Jesus perante a christandade. Rio de Janeiro: Federação Espírita Brasileira, 1932.

- SAYÃO, Antonio Luiz. Elucidações evangélicas. Rio de Janeiro: Federação Espírita Brasileira, 1957.

- SOARES, Sylvio Brito. Vida e obra de Bezerra de Menezes. Rio de Janeiro: Federação Espírita Brasileira, 2006.

- SOUZA, Juvanir Borges (org.). Bezerra de Menezes: ontem e hoje. Rio de Janeiro: Federação Espírita Brasileira, 2001.

- XAVIER, Francisco Cândido. Brasil: coração do mundo, pátria do evangelho. Rio de Janeiro: Federação Espírita Brasileira, 1982.

- WANTUIL, Zeus; THIESEN, Francisco. Allan Kardec. Rio de Janeiro: Federação Espírita Brasileira, 1998, vol. I.

- _ _ _ Allan Kardec. Rio de Janeiro: Federação Espírita Brasileira, 1998, vol. II.

- _ _ Allan Kardec. Rio de Janeiro: Federação Espírita Brasileira, 1998, vol. III.

- WANTUIL, Zeus. Grandes espíritas do Brasil. Rio de Janeiro: Federação Espírita Brasileira, 2002.

- _ _ As mesas girantes e o espiritismo. $1^{\text {a }}$. Ed. Rio de Janeiro: Federação Espírita Brasileira, 1957. 


\section{Publicações umbandistas}

- FERNANDES, Diamantino Coelho. O espiritismo de umbanda na evolução dos povos. In: $1^{\circ}$ Congresso Brasileiro do Espiritismo de Umbanda. Rio de Janeiro: Jornal do Comércio, 1942.

- JUSTINA, Martha. Atualidade da Lei de Umbanda. In: $\mathbf{1}^{\mathbf{o}}$ Congresso Brasileiro do Espiritismo de Umbanda. Rio de Janeiro: Jornal do Comércio, 1942.

- PINTO, Tancredo da Silva; FREITAS, Byron Torres de. Guia e ritual para organização de terreiros de umbanda. $6^{\text {a }}$ Ed. Rio de Janeiro: Edição Eco, 1972.

\section{Publicações católicas}

- FIGUEIREDO, Jackson de. Trechos escolhidos. Rio de Janeiro: Livraria Agir, 1977.

- KLOPPENBURG, Boaventura. Ação pastoral frente ao espiritismo: Orientação para os católicos. Petrópolis: Vozes, 1961.

1964.

O espiritismo: Orientação para os católicos. Petrópolis: Vozes,

- _ _ Espiritismo e fé. São Paulo: Quadrante, 1990.

- LACERDA, D. Pedro Maria. Pastoral da Diocese de São Sebastião do Rio de Janeiro, 15 jul. 1881.

- _ _ Pastoral da Diocese de São Sebastião do Rio de Janeiro, 15 jun. 1882.

- LUSTOSA, Oscar F. A igreja católica no Brasil República. Cem anos de compromisso (1889-1989). São Paulo: Edições Paulinas, 1991.

- MARIA, Pe. Júlio. O catolicismo no Brasil. Rio de Janeiro: Agir, 1950.

- MIRANDA, Padre Antônio. Padre Julio Maria, a sua vida e a sua missão. Belo Horizonte: Imprensa Oficial, 1957.

- REBELLO, Maia José Joaquim. Roma e o espiritismo: Questão religiosa. Opúsculo com uma carta preambular ao Exmo. Sr. Conselheiro Saldanha Marinho, 1877.

- SILVEIRA, D. Manuel Joaquim da. Pastoral da Diocese de Bahia, 16 jun. 1867. 


\section{Periódicos espíritas}

\begin{tabular}{||c|l||}
\hline \multicolumn{1}{|c|}{ Título: } & O Reformador \\
\hline IMPRENTA: & Rio de Janeiro, RJ 1883- \\
\hline \hline Frequência: & Quinzenal \\
\hline \hline Notas: & Primeiro redator: Augusto Elias da Silva \\
\hline Coleção & Exemplares analisados: \\
Nablioteca & $1883-1900 ; 1920 ; 1982$ \\
\hline
\end{tabular}

\begin{tabular}{|c|l||}
\hline \hline Título: & Revue Spirite \\
\hline \hline IMPRENTA: & Paris (França); 1858- \\
\hline \hline Frequência: & Mensal \\
\hline Notas: & Primeiro redator: Allan Kardec \\
\hline Coleção & Exemplares analisados: \\
Biblioteca & $1858 ; 1866-1869 ; 1882 ; 1896$ \\
Nacional: & \\
\hline
\end{tabular}

\begin{tabular}{|c|l||}
\hline \hline Título: & $\begin{array}{l}\text { Revista da Sociedade Acadêmica Deus, Christo e } \\
\text { Caridade }\end{array}$ \\
\hline \hline IMPRENTA: & $\begin{array}{l}\text { Rio de Janeiro : Typ. da Sociedade, 1881- } \\
1882\end{array}$ \\
\hline \hline Frequência: & $\begin{array}{l}\text { Mensal; Sociedade fundada no Império do } \\
\text { Brasil em 3 de out. de 1879. }\end{array}$ \\
\hline Notas: & Redator: Angeli Torterolli \\
\hline $\begin{array}{r}\text { Coleção } \\
\text { Biblioteca } \\
\text { Nacional: }\end{array}$ & $\begin{array}{l}\text { Exemplares analisados: } \\
1881-1882\end{array}$ \\
\hline \hline
\end{tabular}

\begin{tabular}{||c|l||}
\hline \hline Título: & $\begin{array}{l}\text { Revista Espírita: publicação mensal de estudos } \\
\text { psicológicos, feita sob os auspícios de alguns espíritas }\end{array}$ \\
\hline \hline IMPRENTA: & $\begin{array}{l}\text { Rio de Janeiro, RJ : Typ. de Domingos Luiz } \\
\text { dos Santos, 1875 }\end{array}$ \\
\hline \hline Frequência: & Mensal \\
\hline \hline Notas: & $\begin{array}{l}\text { Redator: A. da Silva Neto. } \\
\text { Tipografia a rua Nova do Ouvidor, n.18. }\end{array}$ \\
\hline $\begin{array}{r}\text { Coleção } \\
\text { Biblioteca } \\
\text { Nacional: }\end{array}$ & \begin{tabular}{l} 
Exemplares analisados: \\
\hline \hline
\end{tabular} \\
\hline \hline
\end{tabular}




\begin{tabular}{||c|l||}
\hline Título: & $\begin{array}{l}\text { O Echo d'Alem-Tumulo: monitor d'o spiritismo no } \\
\text { Brazil. }\end{array}$ \\
\hline \hline IMPRENTA: & BA : Typ. D'Diario da Bahia, 1869-1870 \\
\hline \hline Frequência: & Bimestral \\
\hline \hline Notas: & Diretor: Luiz Olympio Telles de Menezes \\
\hline \hline $\begin{array}{r}\text { Coleção } \\
\text { Biblioteca }\end{array}$ & Exemplares analisados: \\
\hline
\end{tabular}

\begin{tabular}{||c|l||}
\hline \multicolumn{1}{|c|}{ Título: } & O Renovador : órgão spirita \\
\hline \hline IMPRENTA: & Rio de Janeiro, RJ : Typ. Cosmopolita, 1882 \\
\hline \hline Frequência: & Desconhecida \\
\hline \hline Notas: & Tipografia de A.G. do Valle, a rua Senhor dos Passos, \\
n.40. \\
\hline $\begin{array}{r}\text { Coleção } \\
\text { Biblioteca } \\
\text { Nacional: }\end{array}$ & Exemplares analisados: \\
\hline
\end{tabular}

\begin{tabular}{||c|l||}
\hline \multicolumn{1}{|c||}{ Título: } & União e Crença : jornal spirita \\
\hline \hline IMPRENTA: & Areas, SP : Typ. do Tymbira, 1881- ? \\
\hline \hline Frequência: & Mensal \\
\hline \hline & $\begin{array}{l}\text { Editores: Joaquim S.M. Leite e Affonso } \\
\text { Távora. } \\
\text { Propriedade do grupo Spirita Fraternidade } \\
\text { Areense. }\end{array}$ \\
\hline $\begin{array}{r}\text { Coleção } \\
\text { Biblioteca } \\
\text { Nacional: }\end{array}$ & Exemplares analisados: \\
\hline
\end{tabular}

\begin{tabular}{||c|l||}
\hline \multicolumn{1}{|c|}{ Título: } & O Espiritismo: órgão dedicado ao estudo da verdade \\
\hline \hline IMPRENTA: & Rio de Janeiro, RJ 1881 \\
\hline \hline Frequência: & 2 vezes por semana \\
\hline \hline Notas: & Tipografia a Rua do Hospício n.127. \\
\hline Coleção & Exemplares analisados: \\
Biblioteca & 1881 \\
\hline
\end{tabular}




\begin{tabular}{||c|l||}
\hline Título: & Religião Espírita : orgam do spiritismo religioso \\
\hline \hline IMPRENTA: & Rio de Janeiro, RJ : Officina de Obras do Jornal do Brasil, \\
& 1897 \\
\hline \hline Frequência: & Mensal \\
\hline \hline Notas: & Redator-chefe: L. da Rocha Barros. \\
\hline \hline $\begin{array}{r}\text { Coleção } \\
\text { Biblioteca } \\
\text { Nacional: }\end{array}$ & Exemplares analisados: \\
\hline \hline
\end{tabular}

\begin{tabular}{||c|l||}
\hline Título: & $\begin{array}{l}\text { O Regenerador: orgam do grupo Caridade nas Trevas, } \\
\text { Centro Espírita S. Francisco Assis }\end{array}$ \\
\hline IMPRENTA: & Rio de Janeiro, RJ , 1890 \\
\hline \hline Frequência: & Mensal \\
\hline $\begin{array}{r}\text { Coleção } \\
\text { Nablioteca }\end{array}$ & Exemplares analisados: \\
\hline
\end{tabular}

\begin{tabular}{|c|l||}
\hline Título: & $\begin{array}{l}\text { Espiritualismo Experimental: orgam consagrado a todos } \\
\text { os ramos de conhecimentos e especialmente a Sciencia } \\
\text { Spirita }\end{array}$ \\
\hline \hline IMPRENTA: & São Paulo, SP : Typ. Uniao, 1886- ? \\
\hline \hline Frequência: & Mensal \\
\hline \hline Notas: & $\begin{array}{l}\text { Epigrafe: "Fora da Caridade não há } \\
\text { Salvação". }\end{array}$ \\
\hline $\begin{array}{r}\text { Coleção } \\
\text { Biblioteca } \\
\text { Nacional: }\end{array}$ & Exemplares: \\
\hline
\end{tabular}

\section{Periódicos católicos}

\begin{tabular}{||c||l||}
\hline \multicolumn{1}{|c||}{ Título: } & O Apóstolo \\
\hline \hline IMPRENTA: & Rio de Janeiro, RJ 1866-1901 \\
\hline \hline Frequência: & Três vezes por semana \\
\hline Notas: & Fundado em janeiro 1866 (não circulou de \\
março 1897 a março 1898)
\end{tabular}




\section{Periódicos laicos}

- BEGUOCI, Leandro. Caderno especial 'Religião’. Folha de S. Paulo. São Paulo, 06 maio 2007.

- A Notícia, 11 abril de 1900.

- Cidade do Rio, 11 abril de 1900.

- Jornal do Brasil, 12 abril de 1900.

- O Paiz, 12 abril de 1900.

- Jornal do Brasil 10 de outubro de 1896.

\section{Sites visitados}

- $\quad$ www.espirito.org.br

- www.febnet.org.br

- www.feesp.org.br

- www.omensageiro.com.br

- www.cefamiami.com/sitesespiritas/

- www.use-sp.com.br

- www.useerj.org.br

- www.spiritismonline.net

- www.abrade.com.br

- www.amebrasil.org.br/

- www.spiritist.org

- www.oclarim.com.br/o_clarim/o_clarim.html

- www.oclarim.com.br

- www.allan-kardec.com

- www.cefamiami.com

- http://perso.orange.fr/charles.kempf/

- http://spirite.free.fr/

- www.espirito.com.br

- www.uniafro.hpgplus.com.br

- www.ifres.org/

- http://perso.orange.fr/union.spirite/

- www.ade-rj.org/

- http://umbanda.sites.uol.com.br

- www.umbanda.com.br/

- www.umbanda.org/

- http://orbita.starmedia.com

- www.frecab.com.br

- www.geocities.com/Paris/Bistro/9775/ 
- $\quad$ www.fietreca.org.br

- www.fbu.com.br

- www.souesp.com.br

- www.uucab.com.br

- www.umbandabrasil.com.br/

- www.telma.org.br

- $\quad$ www.mundoespirita.com.br

- www.ide.org.br

- www.iceb.org.br

- $\quad$ www.acervoespírita.net

- www.espirito.com.br

- www.union-spirite.fr/

- www.novavoz.org.br

- http://pagesperso-orange.fr/charles.kempf/

- www.casarecupbenbm.org.br

- $\quad$ www.grupodosoito.com.br 